UNIVERSIDADE DE SÃO PAULO

FACULDADE DE ECONOMIA, ADMINISTRAÇÃO E CONTABILIDADE DEPARTAMENTO DE ADMINISTRAÇÃO

PROGRAMA DE PÓS-GRADUAÇÃO EM ADMINISTRAÇÃO

COMPORTAMENTO DO CONSUMIDOR DE ALIMENTOS NO BRASIL:

UM ESTUDO SOBRE A CARNE SUÍNA

Maria Stella Beregeno Lemos de Melo Saab

Orientador: Prof. Dr. Marcos Fava Neves

Coorientadora: Prof ${ }^{\mathrm{a}}$. Dr ${ }^{\mathrm{a}}$. Márcia Dutra de Barcellos

Versão Corrigida

(versão original disponível na FEA)

SÃo PAULO

2011 
Prof. Dr. João Grandino Rodas

Reitor da Universidade de São Paulo

Prof. Dr. Reinaldo Guerreiro

Diretor da Faculdade de Economia, Administração e Contabilidade

Prof. Dr. Adalberto Américo Fischmann

Chefe do Departamento de Administração

Prof. Dr. Lindolfo Galvão de Albuquerque

Coordenador do Programa de Pós-Graduação em Administração 


\title{
COMPORTAMENTO DO CONSUMIDOR DE ALIMENTOS NO BRASIL: UM ESTUDO SOBRE A CARNE SUÍNA
}

\author{
Tese apresentada ao Departamento de \\ Administração da Faculdade de Economia, \\ Administração e Contabilidade da Universidade \\ de São Paulo como requisito para obtenção do \\ título de Doutora em Administração \\ Orientador: Prof. Dr. Marcos Fava Neves \\ Coorientadora: Prof ${ }^{\mathrm{a}}$. Dra ${ }^{\mathrm{a}}$. Márcia Dutra de Barcellos
}

\section{SÃo PAULO}




\section{FICHA CATALOGRÁFICA}

\section{Elaborada pela Seção de Processamento Técnico do SBD/FEA/USP}

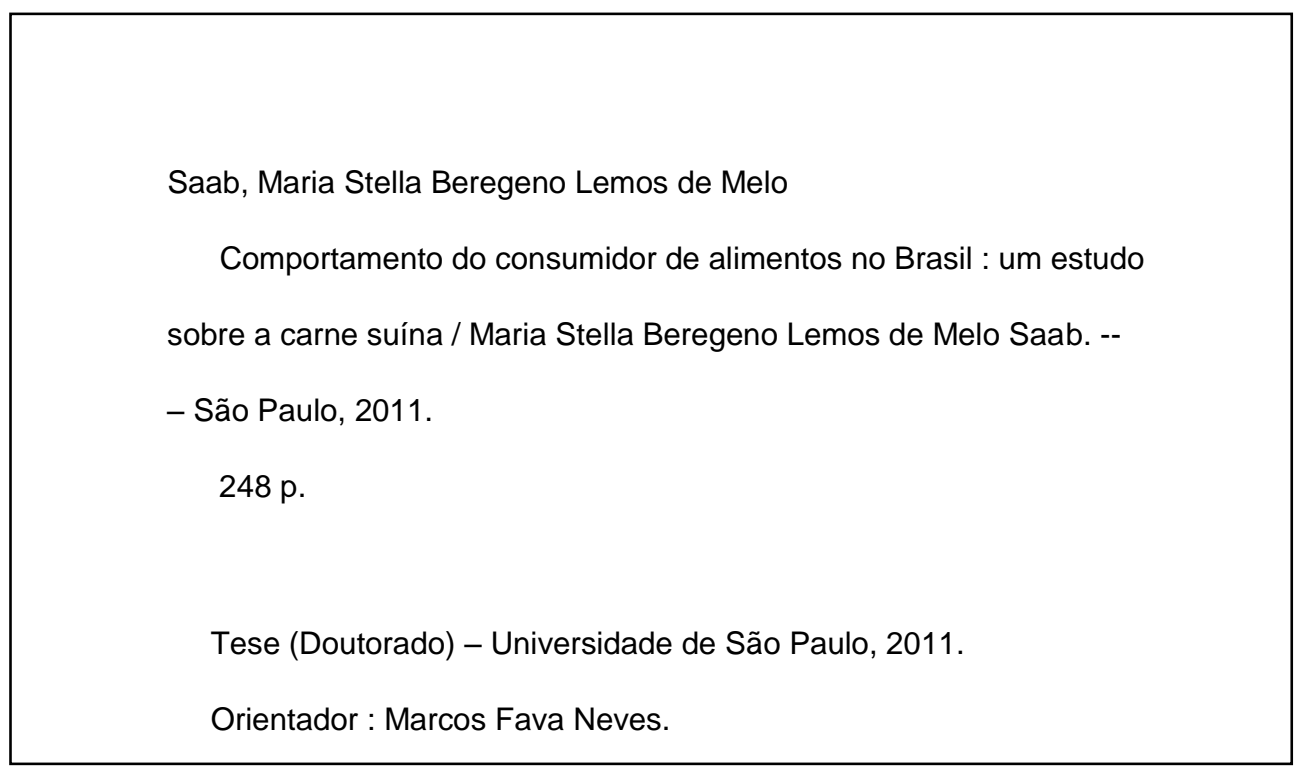


Ao Fauzi, meu amor;

À Marina e ao Fauzi Neto, minhas razões de viver; À Mamãe, que está ao meu lado em todos os momentos. 
Agradeço em primeiro lugar ao meu orientador, Prof. Dr. Marcos Fava Neves, pelo convite para integrar o projeto Q-PorkChains, que ofereceu a inspiração para este trabalho, e pelo incentivo constante.

À Prof ${ }^{a}$. Dr ${ }^{\mathrm{a}}$. Márcia Barcellos, que conheci em Aarhus, já no âmbito do Q-Porks, e hoje minha coorientadora, amiga e "luz no fim do túnel". Juntamente com o Bernardo, chegou a me receber em sua casa em Porto Alegre. Sem sua ajuda, este trabalho com certeza não teria sido concluído.

Aos professores Eduardo Spers e Sylvia Saes, pela compreensão e observações importantíssimas no difícil momento do Exame de Qualificação, as quais me possibilitaram direcionar o trabalho da maneira correta.

À Daielly Mantovani, minha "tutora" nas análises estatísticas em Ribeirão Preto, e ao prof. Dr. Marcelo Perin, da PUC-RS, pelas análises estatísticas mais elaboradas.

Ao pessoal do Módulo I do Projeto Q-PorkChains, pelo acolhimento na equipe e no projeto, e pela paciência em me explicar assuntos teóricos que eu não compreendia e meu inglês não acompanhava: prof. Klaus Grunert, que convidou o Marcos, e me aceitou também; aos profs. Wim Verbeke e George Chrissochoidis; e especialmente ao Armando Perez-Cueto, Jens Kruegler, Athanassios Krystallis, que me ofereceram grande parte das análises estatísticas presentes no trabalho. Também ao Bjarne Taulo Sorensen e Susanne Pedersen, que além de me receberem no MAPP, em Aarhus, me proporcionaram visitas interessantíssimas e altamente instrutivas a empresas e produtores de suínos na Dinamarca, em 2008.

Ao próprio projeto, que funcionou como uma bolsa durante os dois primeiros anos do Doutorado. Além disto, foi quem bancou toda a parte prática da pesquisa, contratando a TNSInterscience para aplicá-la.

À FEA/USP, pela bolsa da CAPES nos dois últimos anos da tese, que me possibilitou dedicação quase exclusiva. À sempre prestativa e simpática Valéria, da Secretaria de Administração, pela ajuda sempre que precisei. Também à Cida, Lucimara, Luciane, e ao pessoal da PPGA, pelo apoio institucional e pelas facilidades oferecidas.

Aos amigos da Markestrat, pelo apoio e pelas discussões. Em especial ao Marco Antonio, companheiro e amigo do começo ao fim, à Carla e ao Leandro, companheiros de viagens e disciplinas, à amiga Luísa, à Mariela e à Cláudia, pela ajuda burocrática, ao Vinícius, Lucas, Mairun, MAC, Luciano, Rossi, Fred, JC e todos os outros.

Ao pessoal da TNS-Interscience no Brasil, em especial ao Alexandre Momma, que continuou nos ajudando e formatando dados mesmo após o término da pesquisa.

Aos amigos Barão (por TUDO), Paulo Eduardo e José Paulo Cândido Júnior, da Gold Meat, pelas inúmeras visitas e esclarecimentos prestados sempre que precisei. 
Ao Fauzi, Karina e Rita, por me aguentarem no escritório durante um ano inteiro!...

Ao pessoal da ABCS, em especial aos Srs. Rubens Valentini, Fabiano Coser e Fernando Barros, pelas consultas oferecidas sobre o SAG dos suínos e pelo convite para a PorkExpo 2008 e para assistir ao Seminário do Plano Nacional de Desenvolvimento da Suinocultura em Foz do Iguaçu, em 2009.

Ao Sr. Osler Desouzart, que me ofereceu informações confiáveis e atualizadas sobre o mercado de suínos no Brasil e no mundo.

Ao prof. Dirceu Tornavoi de Carvalho, pelas dicas e livros emprestados sobre o comportamento do consumidor.

À minha irmã Tina e ao Arnaldo, Juliana, Letícia e Felipe, por me oferecerem um local de destino e descanso em seu apartamento em São Paulo durante todo o tempo de créditos de disciplinas, nos Congressos, Seminários e qualquer outra ida à FEA.

A toda a minha família, por aguentar meu estresse e mau humor principalmente, na fase final da tese, e me incentivar mesmo assim. Tetê, Beto e Mariana, Lila, Zita, Ary, Maurício e Fernanda, Juninho, Vanessa e Beatriz, Ana, Donato, Lucas e Daniel, obrigada!

Também ao outro braço da família, Seu Fauzi e D. Yara, Rosa Lúcia, Guilherme e Isabela, Gustavo, Cíntia, Mariana, Lívia, Maria Eduarda e Luísa.

E finalmente à Helena, nossa companheira há tantos anos, e que me ajuda a manter "a casa em ordem" para que eu possa me dedicar mais ao meu lado profissional. 


\section{RESUMO}

Consumidor é o agente econômico que faz girar toda e qualquer atividade na sociedade, seja um bem, serviço ou qualquer forma de produção que se possa gerar. Assim, de sua vontade dependem a manutenção, o sucesso ou o fracasso de qualquer uma dessas citadas atividades. Quanto mais os esforços de marketing das empresas estiverem concentrados desde o início no consumidor final que se deseja atingir, maiores serão as chances de que o produto ou serviço seja bem aceito por ele e assim se obtenha sucesso no empreendimento. No entanto, para que se atinja esse objetivo de atender ao consumidor final, é preciso que se saiba quem é esse consumidor final, quais são seus gostos, suas preferências, quais atributos deseja encontrar nos produtos que consome e em quais proporções. E isso só se consegue estudando-o, realizando pesquisas que aliem o estudo científico à realidade empírica, indo até ele e questionando-o a respeito desses assuntos com sólidas bases acadêmicas. $\mathrm{O}$ que este trabalho pretendeu foi exatamente realizar um estudo nesse sentido, ou seja, com uma base teórica (a teoria do Comportamento do Consumidor), chegou-se até o consumidor final de carne suína com uma pesquisa estruturada que envolvia questões sobre estilo de vida, atitudes e valores em relação aos produtos e à produção de suínos, além de ocasiões, frequência, locais e maneiras de compra e de consumo de carne suína e produtos feitos à base de carne suína. Esta pesquisa utilizou dados do projeto europeu Q-PorkChains, do qual a pesquisadora do presente estudo e seus orientadores fizeram parte. Utilizaram-se nesta tese dados de apenas um dos cinco módulos do projeto, o módulo que se refere ao Consumo, e apenas a pesquisa aplicada no Brasil. Por tratar-se de um grande questionário que envolvia uma quantidade bastante diversa de assuntos, a tese não incluiu análises de todas as partes do questionário. Estudos posteriores pretendem cobrir as áreas que ainda não foram analisadas, além de se realizarem comparações entre os resultados encontrados na amostra brasileira e aqueles dos países europeus pesquisados e também da China, outro país participante da pesquisa. Foram feitas várias análises estatísticas, porém nem todos os construtos integrantes da pesquisa inicial puderam ser validados na amostra brasileira. A hipótese de que as atitudes dos consumidores brasileiros de carne suína em relação ao meio ambiente e à natureza, à produção industrial de alimentos, ao progresso tecnológico e ao etnocentrismo seriam influenciadas pelos conceitos do $F R L$ e $P V Q$, que tanto essas atitudes quanto os próprios conceitos influenciariam a maneira como o consumidor vê a produção de suínos, e que, tudo isto somado, seriam gerados os comportamentos de consumo do consumidor final de carne suína no Brasil não se confirmou, uma vez que foi encontrada pouca relação entre os construtos pesquisados e o consumo. Ainda assim, além da importância de se ter a replicação de um estudo europeu no Brasil, esta tese tem como principais contribuições a verificação de uma série de informações que funciona como indicadores de tendências de compra e consumo de carne suína e produtos derivados, e a utilização de escalas ainda pouco utilizadas no Brasil no setor de agronegócios, como o Food Related Lifestyle (FRL) e o Pictorial Values Questionnaire (PVQ). 


\begin{abstract}
Consumer is the economic agent that makes all and every activity in human society run, be it a good, a service or any other form of production that can be generated. In this sense, the success or failure of any of those cited activities depends on his needs and wants. The more the companies' marketing efforts are concentrated from the beginning on the final consumer, the bigger will be the chances that the good or service is well accepted by this consumer and that it becomes a success. But in order to achieve that objective, it is necessary to know who is the final consumer, which are his tastes, his preferences, which are the attributes he wants to find in the products he consumes and in which proportions. And this can only be achieved by studies that join together scientific knowledge and empirical reality, going directly to the final consumer to ask him about those issues with solid academic basis. This thesis intended to make a study that, based on a theoretical basis (the theory of Consumer Behavior), reached the pork consumer with a structured research that included questions about lifestyle, values and attitudes towards pork products and swine production, and also questions about occasions, frequencies, places and ways of purchase of pork and pork products. This research used data from a comprehensive European project called Q-PorkChains, in which the researcher of this thesis and her advisors made part. This study used data from only one of the five modules of the project, the one that refers to Consumption, and only data from Brazil. Being a big questionnaire that involved a very diverse number of issues, not all parts of the questionnaire were analyzed in this thesis. Further studies should cover the non analyzed areas, and also make comparisons between the results found in the Brazilian sample and the ones found in the European countries and in China, the other country that made part of the research. Many statistical analyses were made but not all of the constructs that made part of the initial study could be validated in the Brazilian sample. The hypothesis that the attitudes of Brazilian pork consumers towards the environment and nature, industrial production of food, technological progress and ethnocentrism were influenced by the constructs of FRL and PVQ, that such attitudes and the concepts both influenced the way the consumer views swine production, and that everything together generated the behavior of the pork consumer in Brazil was not confirmed. In fact, little relation was found between the researched constructs and consumption. Even though, besides the importance of replicating in Brazil an European study, this thesis has as main contributions the verification of a series of information that serve as indicators of tendencies of purchase and consumption of pork and pork products, and the use of scales that have been little used in Brazil in the agribusiness sector, such as the Food Related Lifestyle (FRL) and the Pictorial Values Questionnaire (PVQ).
\end{abstract}




\section{SUMÁRIO}

\section{LISTA DE ABREVIATURAS E SIGLAS \\ LISTA DE QUADROS.}

\section{LISTA DE TABELAS}

\section{LISTA DAS DEMAIS ILUSTRAÇÕES}

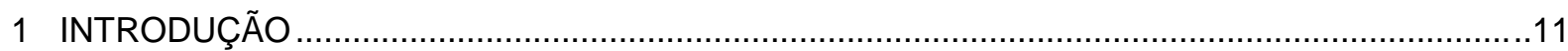

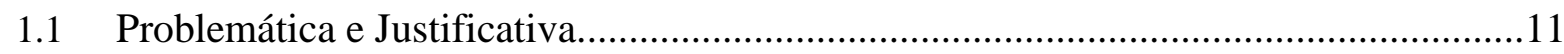

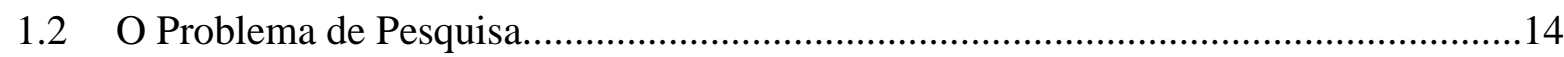

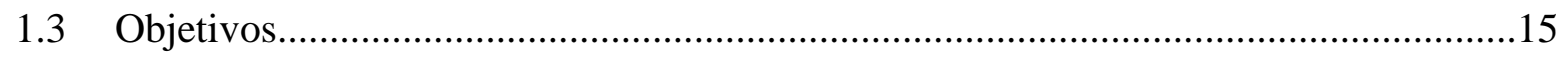

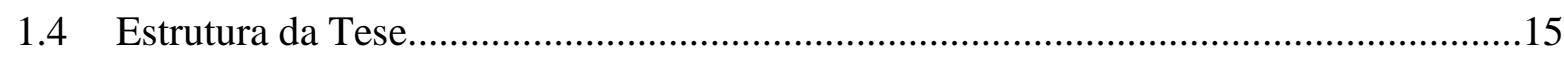

2 FUNDAMENTAÇÃO TEÓRICA...................................................................................

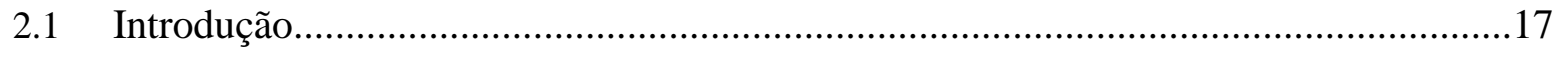

2.2 Uma Visão Geral sobre o Comportamento do Consumidor...........................................17

2.2.1 Teoria neoclássica do comportamento do consumidor..............................................19

Um exemplo de aplicação no sistema carnes.............................................................20

2.2.2 Teoria comportamental...................................................................................22

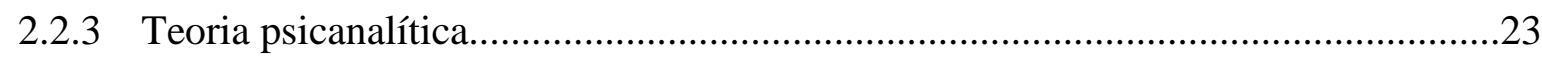

2.2.4 Teorias social e antropológica.............................................................................24

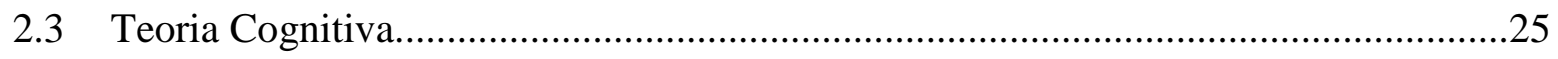

2.3.1 Fatores de influência no processo de decisão de compra.........................................25

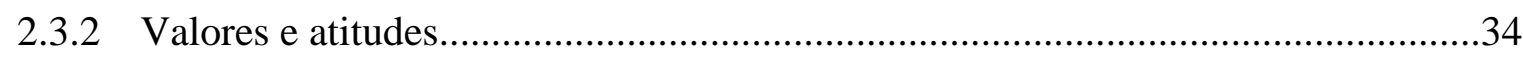

2.3.2.1 A formação das atitudes........................................................................38

2.3.2.2 Modelos de formação das atitudes.......................................................42

2.4 A Teoria da Ação Racional e a Teoria do Comportamento Planejado..........................46

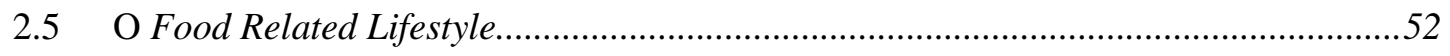




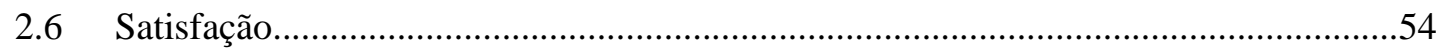

2.7 O Estudo do Comportamento do Consumidor de Alimentos.........................................57

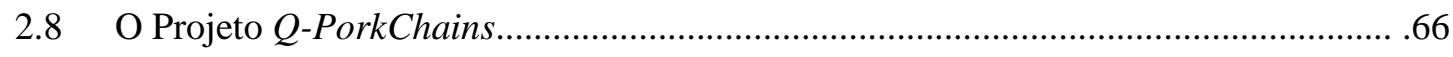

3 O SISTEMA AGROINDUSTRIAL DA CARNE SUÍNA NO BRASIL .............................................71

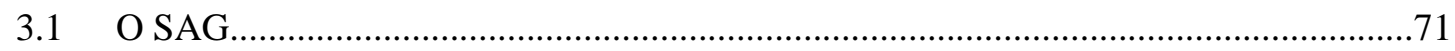

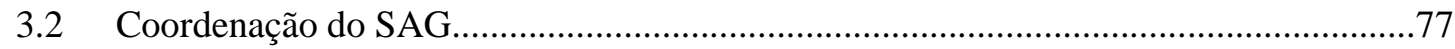

3.3 O Mercado da Carne Suína no Brasil - Consumo........................................................81

3.4 O Mercado da Carne Suína no Brasil - Produção.............................................................83

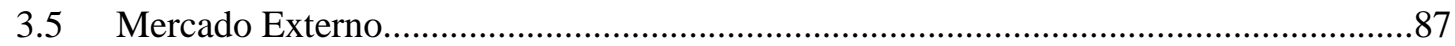

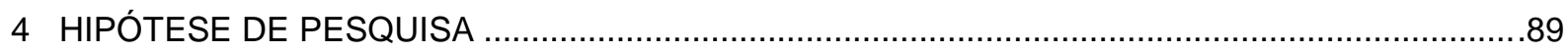

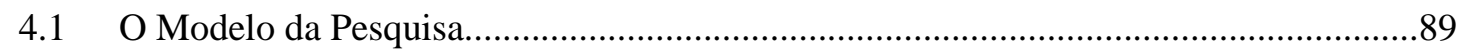

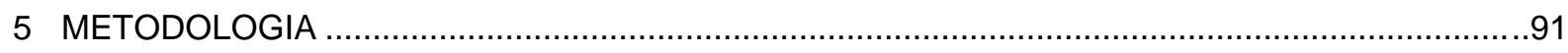

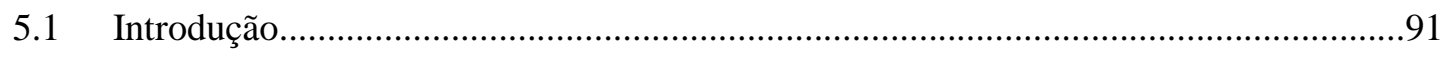

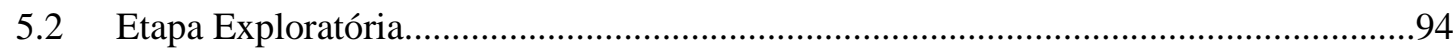

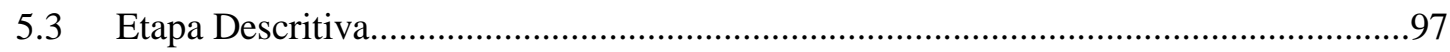

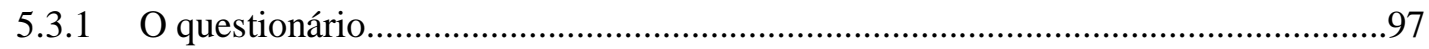

Seção 1 - Características sociodemográficas e antropométricas (peso e altura autorreportados) do respondente........................................................................................ 101

Seção 2 - Questões sobre o estilo de vida dos respondentes.................................102

Seção 3 - Sistema de valores dos respondentes...................................................105

Seção 4 - Atitudes em relação a meio ambiente e natureza, produção industrial de alimentos e progresso................................................................................................... 107

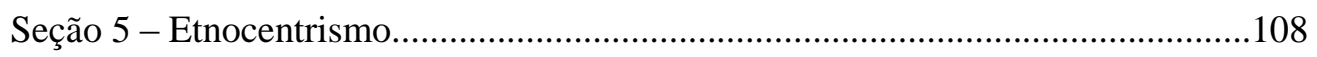

Seção 6 - Atitudes em relação a como a produção de alimentos afeta o meio

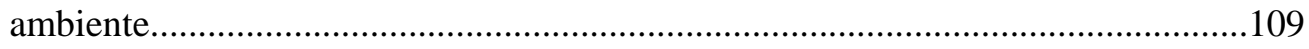

Seção 7 - Atitudes em relação aos sistemas de produção de suínos...........................109

Seção 8 - O comportamento de consumo............................................................113

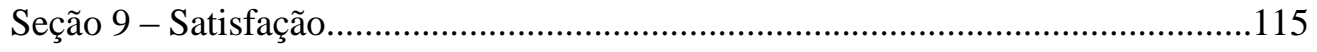


5.3.2 Escalas utilizadas

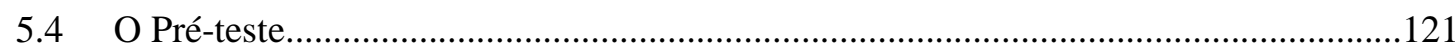

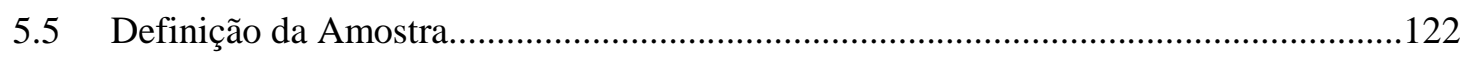

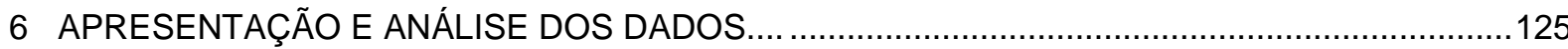

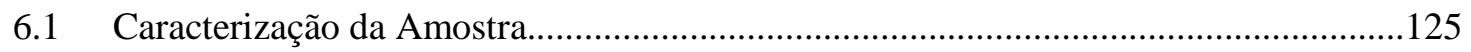

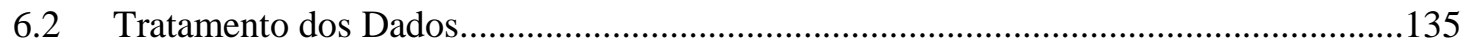

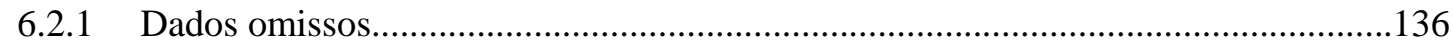

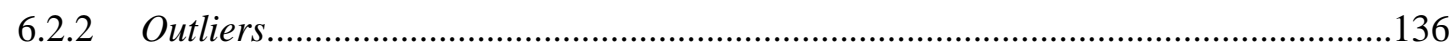

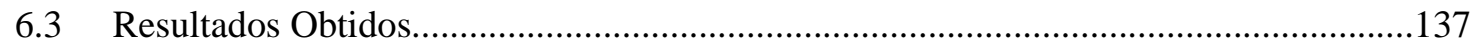

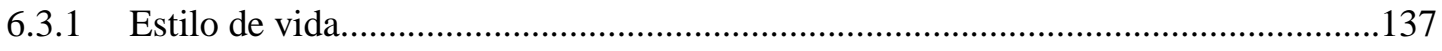

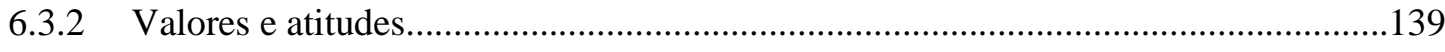

6.3.2.1 Análise fatorial exploratória................................................................139

6.3.2.2 Análise de correlação.......................................................................145

6.3.2.3 Análises de regressão entre atitudes e valores e o consumo de produtos frescos e processados.......................................................................................147

6.3.2.4 Análise de regressão entre atitudes e valores com os respondentes separados por

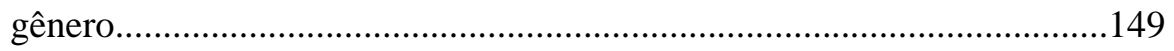

6.3.2.5 Análise de regressão entre atitudes e valores com os respondentes separados por

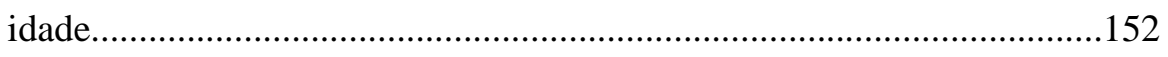

6.3.3 Atitudes do cidadão em relação aos sistemas de produção suínos..............................156

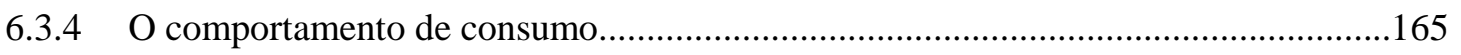

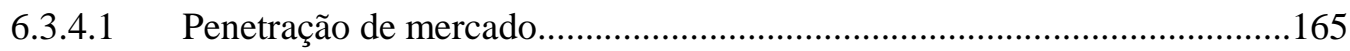

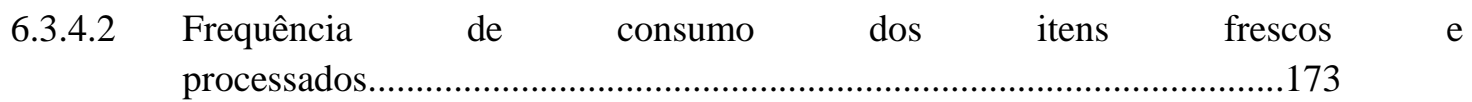

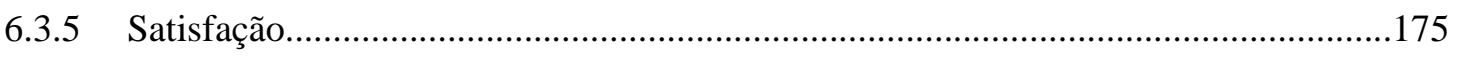

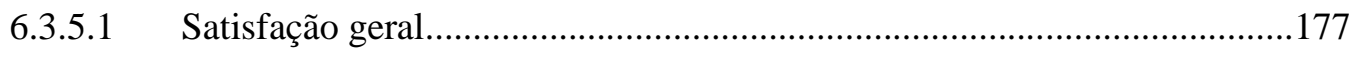

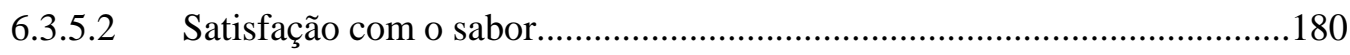


6.3.5.3 Satisfação com as qualidades saudáveis...............................................181

6.3.5.4 Satisfação com a facilidade de preparo..................................................183

6.3.5.5 Satisfação com o preço..................................................................... 184

6.3.6 Com quais produtos o respondente combina o consumo de carne suína....................187

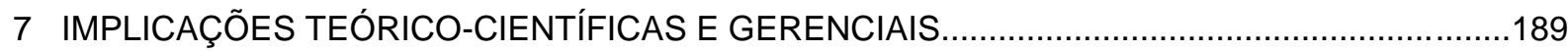

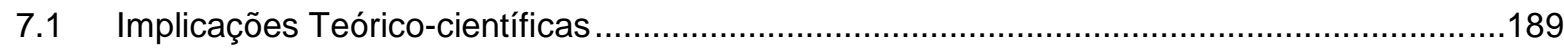

7.2 Implicações Gerenciais da Pesquisa: Mensagens ao SAG da Carne Suína ........................190

7.3 Síntese dos Resultados .............................................................................................194

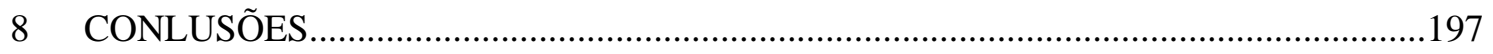

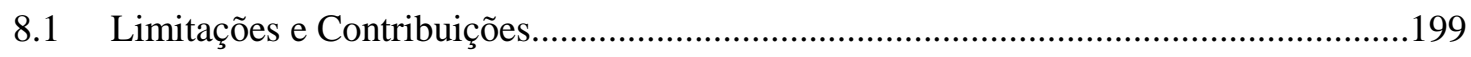

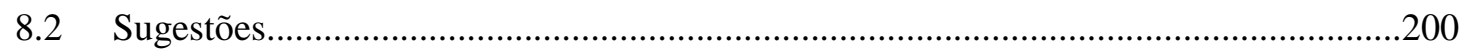

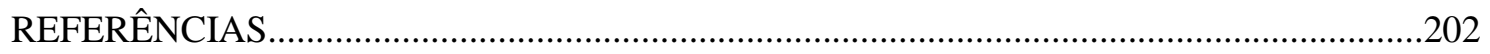

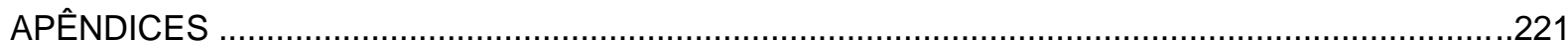

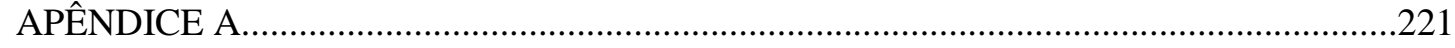

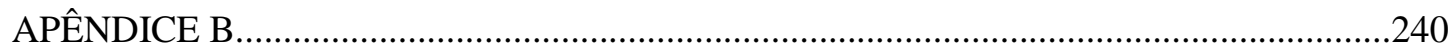

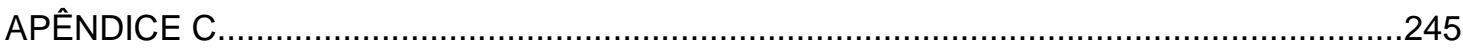

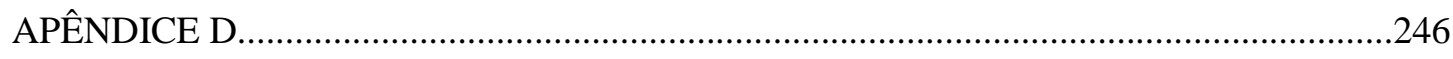

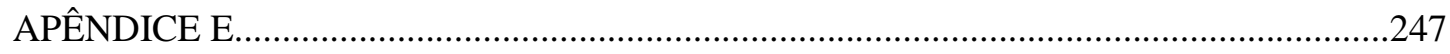

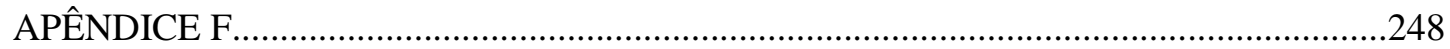




\section{LISTA DE ABREVIATURAS E SIGLAS}

ABIPECS: Associação Brasileira das Indústrias Produtoras e Exportadoras de Carne Suína ABCS: Associação Brasileira dos Criadores de Suínos

APCS: Associação Paulista dos Criadores de Suínos

CEPEA: Centro de Estudos Avançados em Economia Aplicada

ESALQ: Escola Superior de Agricultura "Luiz de Queiroz"

SAG: Sistema Agroindustrial

USDA: United States Department of Agriculture

USP: Universidade de São Paulo 


\section{LISTA DE QUADROS}

Quadro 1 - Estudos sobre o comportamento do consumidor de carnes utilizando a TPB ........49

Quadro 2 - Estudos sobre o comportamento do consumidor de carnes no Brasil...................63

Quadro 3 - Construtos e instrumentos utilizados na construção do questionário aplicado nesta

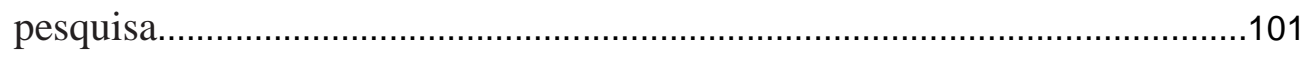

Quadro 4 - Valores Ilustrados de Schwartz....................................................................106

Quadro 5 - Atributos-chave e seus níveis .......................................................................110

Quadro 6 - Perfis completos utilizados na pesquisa ........................................................111

Quadro 7 - Técnicas comuns para medir atitude......................................................118

Quadro 8 - Análise fatorial dos valores e atitudes da pesquisa e suas dimensões ..................141

Quadro 9 - Síntese dos resultados encontrados e suas implicações .......................................194 


\section{LISTA DE TABELAS}

Tabela 1 - Distribuição da amostra por idade e gênero ……………………………………......125

Tabela 2 -Distribuição da amostra por idade, gênero e cidade ..................................................126

Tabela 3 - Quantidade de respondentes que conhecem produtores de suínos ..........................126

Tabela 4 - Quantidade de respondentes que moram perto de alguma criação de suínos ........127

Tabela 5 - Distribuição da amostra por situação familiar e nível de escolaridade....................127

Tabela 6 - Características sociodemográficas dos respondentes da amostra por estado.........129

Tabela 7 - Situação nutricional da amostra por gênero ………………………………….........131

Tabela 8 - Situação nutricional da amostra por estado ..........................................................132

Tabela 9 - Medidas antropométricas e IMC por gênero …………………………………..........134

Tabela 10 - Estatística descritiva e confiabilidade do $F R L$ no Brasil ........................................138

Tabela 11 - Análise de correlação entre as variáveis aglomeradas de valores e atitudes .......146

Tabela 12 - Média e desvio padrão das utilidades da pesquisa ……………………………......156

Tabela 13 - Utilidades médias da amostra por cidade …………...........................................161

Tabela 14 - Valores médios e desvio padrão das utilidades agregadas .....................................162

Tabela 15 - Valores médios das utilidades agregadas (geral e por

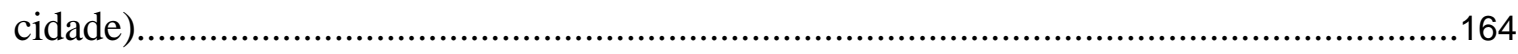

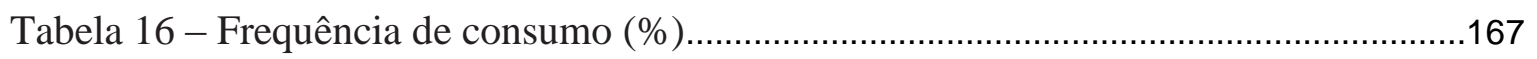

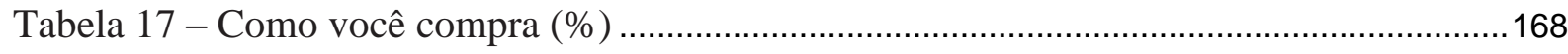

Tabela 18 - Onde você compra $(\%)$.................................................................................... 169

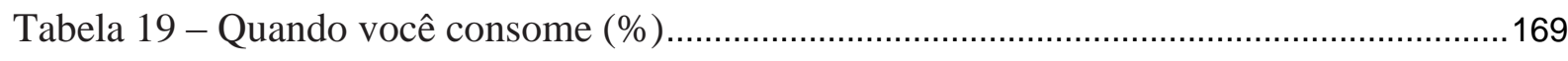

Tabela 20 - Com quem (\%) .............................................................................................171

Tabela 21 - Onde você come (\%) …………………………………………………....172

Tabela 22 - Quanto de preparo (\%) f...…………………………………………….......173

Tabela 23 - Análise fatorial da frequência de consumo dos itens frescos e processados e seus

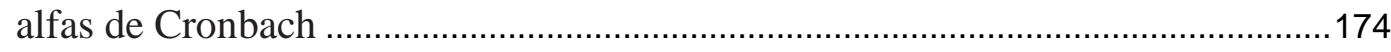

Tabela 24 - Percepção de qualidade e níveis de satisfação por produto ....................................176 
Tabela 25 - Estatísticas descritivas de cada dimensão por cidade ........................................177

Tabela 26 - Cidades com diferenças significativas de satisfação geral ..................................178

Tabela 27 - Estatísticas descritivas da satisfação com o sabor para as cidades do estudo......180

Tabela 28 - Satisfação com as qualidades saudáveis do produto .............................................181

Tabela 29 - Satisfação com a facilidade de preparo..............................................................183

Tabela 30 - Satisfação com o preço do produto .................................................................184

Tabela 31 - Variáveis de influência e beta padronizado para as categorias de produto..........186

Tabela 32 - Estatísticas gerais de preferências por acompanhamentos aos produtos

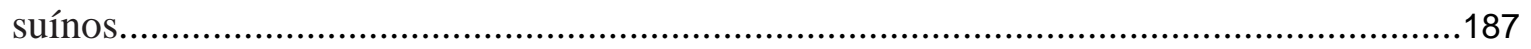




\section{LISTA DAS DEMAIS ILUSTRAÇÕES}

Figura 1 - Fatores que influenciam o comportamento do consumidor...............................26

Figura 2 - A visão tradicional tricomponente da atitude ...............................................43

Figura 3 - Uma visão contemporânea da relação entre crenças, sentimentos, atitudes, intenção

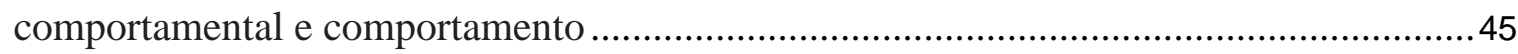

Figura 4 - Fatores que determinam a intenção comportamental .........................................48

Figura 5 - Quatro elos em uma cadeia simples de valor ................................................ 79

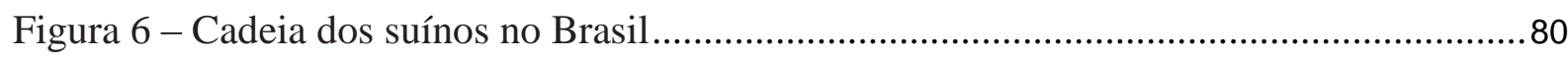

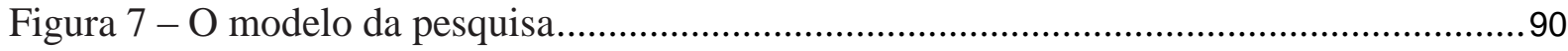

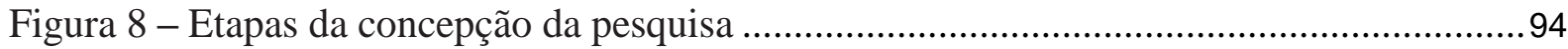

Gráfico 1 - Situação nutricional da amostra por cidade ................................................. 133

Gráfico 2 - Utilidades da densidade da produção de suínos ............................................. 157

Gráfico 3 - Utilidades do alojamento da produção .......................................................... 158

Gráfico 4 - Utilidades do esforço para diminuir impacto ambiental ................................. 158

Gráfico 5 - Utilidades para o teor de gordura da carne ................................................. 159

Gráfico 6 - Utilidades para a qualidade da produção ........................................................ 160

Gráfico 7 - Utilidades da

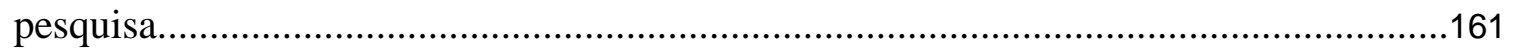

Gráfico 8 - Nível de penetração (\%) dos produtos utilizados na

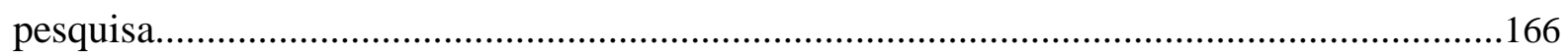





\section{INTRODUÇÃO}

\subsection{Problemática e Justificativa}

Estudar o comportamento do consumidor, segundo Barcellos et al (2005), assumiu um papel estratégico nos estudos das empresas, uma vez que resultados de pesquisas indicam que quanto mais satisfeitos estiverem os consumidores, mais tempo e recursos eles tenderão a despender com aquelas que melhor os atenderem.

Dessa maneira, estudos que utilizem métodos científicos no sentido de procurar conhecer melhor o consumidor final, seus hábitos, preferências, gostos e vontades são extremamente importantes para que se possa oferecer, às empresas e aos próprios sistemas agroindustriais (SAGs), diretrizes, caminhos para onde possam direcionar de maneira mais eficaz seus esforços de marketing (CHIUSOLI et al, 2008; SILVA, 2009).

Primeiramente, deve-se escolher como objetivos alvos passíveis de serem atingidos e com boa probabilidade de serem alcançados. Além disso, um melhor conhecimento de seu consumidor final permite às empresas formular estratégias factíveis e de acordo com seus recursos humanos, financeiros e de tempo, o que as torna importantes diferenciais de competitividade para as organizações (BARCELLOS, 2007). Há também a possibilidade de decidir entre segmentar ou não o mercado, uma vez que a empresa pode resolver agir de modo a atingir o mercado como um todo ou simplesmente dividi-lo em segmentos diferentes com características comuns entre si (KOTLER, 2000) e focar um ou vários desses segmentos, poupando esforços que de outra maneira poderiam ser desperdiçados ao agir sem um foco definido (AAKER, 2001, p. 43).

O que se busca ao realizar uma pesquisa que investigue o comportamento do consumidor final de alimentos é justamente conhecer um pouco mais sobre seus hábitos e preferências, e agir no sentido de oferecer aos interessados (empresas, produtores de alimentos, estudiosos) alguns indicativos prováveis de como fazer para tornar os produtos mais atraentes no momento da compra.

Em 2009, o agronegócio movimentou no Brasil, desde o campo até o consumidor final, $\mathrm{R} \$$ 735.276 milhões, representando $23,08 \%$ do PIB (produto interno bruto) nacional (CEPEA- 
ESALQ/USP, 2010) e um terço dos empregos no país. Segundo Daher (2010), a agropecuária movimenta 38,5\% das exportações e emprega cerca de 40 milhões de pessoas. Isto por si só, revela um pouco da importância do tema para a economia nacional.

De acordo com o último Censo Agropecuário do IBGE, de 2006, há no país cerca de 5,2 milhões de propriedades rurais, a maioria em posse de produtores familiares. A agricultura é a atividade econômica em 51,5\% delas, enquanto a pecuária é predominante em $44 \%$, a produção florestal, em $4 \%$, e a pesca e aquicultura, em 0,5\% (AGÊNCIA BRASIL, 2010).

Segundo Daher (2010), "a atividade agropecuária é provedora da extensa cadeia de alimentos que temos em nossas mesas; fornece, ainda, a infinidade de bens imprescindíveis no nosso dia a dia e de bilhões de pessoas em todo o mundo".

Dentro do agronegócio, a suinocultura é um dos setores que mais vêm crescendo. De 1999 a 2009, a produção apresentou crescimento de 136\%. Além da expansão do número de animais, a produtividade da suinocultura industrial melhorou $21 \%$ entre 2002 e 2009, o que fez com que o Brasil chegasse ao posto de quarto maior produtor e exportador mundial (CEPEA-ESALQ/USP, 2009).

A cadeia suína brasileira - com 30 milhões de cabeças, produção de três milhões de toneladas de carne, geração de 630 mil empregos diretos e indiretos, investimentos no campo e na indústria de $\mathrm{R} \$ 9$ bilhões, receita de $\mathrm{R} \$ 84$ bilhões, sendo $\mathrm{R} \$ 30,4$ bilhões no mercado interno, $\mathrm{R} \$ 2,6$ bilhões no mercado externo, $\mathrm{R} \$ 51,6$ bilhões na distribuição e no varejo - é uma importantíssima atividade econômica, principalmente no sul e sudeste do país (CAMARGO NETO, 2010).

Apesar disso, o consumidor final, que é quem faz movimentar toda a economia (NEVES et al, 2000) e quem decide sobre o crescimento de cada uma das cadeias agroindustriais, tem sido pouco estudado. Assim, sempre há espaço para conhecer mais a respeito desse importante agente econômico. Quem é ele, como se comporta, como faz suas compras de alimentos, onde as faz, com qual periodicidade, quais critérios utiliza para escolher entre um estabelecimento comercial e outro, quais critérios utiliza para escolher entre um alimento e outro, quais atributos valoriza nessas escolhas, quem são seus influenciadores nas escolhas de compra e de consumo... As questões são inúmeras e, até agora, têm sido pouco estudadas, especialmente de maneira formal e criteriosa (MACHADO FILHO, 2000; GARCIA; BLISKA, 2000; BRISOLA; CASTRO, 2005; BARCELLOS, 2007; SILVA, 2009). 
Segundo Neves et al (2010, p. 13), um exemplo interessante da importância de estudar o comportamento do consumidor, ao descrever a rede da empresa focando o consumidor final, vem da indústria de serviços de alimentação, "que tem apresentado crescimento devido à crescente importância para o consumidor final de atributos como conveniência e entretenimento". Isso causa grande impacto na maneira como os moinhos de trigo, por exemplo, realizam suas vendas, levando-os a estruturar seus canais de distribuição para focar também empresas de serviços de alimentação.

É também muito importante que o consumidor fique satisfeito ao consumir o produto, para que volte a fazê-lo, indique-o a outras pessoas e torne-se assim um consumidor fiel do produto, oferecendo certa garantia ao produtor de que haverá no futuro demanda para seus produtos (BAPTISTA, 2005).

Sheth et al (1988, p. 117), ao se referirem ao desenvolvimento de teorias compreensivas do comportamento do consumidor, afirmam que "o comportamento do comprador é muito complexo e altamente dinâmico para ser completamente explicado por modelos unidimensionais e transversais".

Acredita-se que as atitudes dos consumidores em relação aos produtos e aos sistemas produtivos exercem significativa influência sobre seu comportamento de compra. Além disso, os valores que os consumidores possuem e que são formados por seus conhecimentos e experiências vividos ao longo de suas vidas vão determinar em grande parte quais serão os produtos que irão consumir em maior ou menor quantidade e com maior ou menor frequência.

Grunert et al (2004) comentam que os consumidores baseiam suas decisões de compra em um pequeno número de quesitos preestabelecidos, os quais têm pouco valor preditivo sobre a qualidade verdadeiramente obtida durante o consumo do produto. Com isso, existe a tendência de delegar-se a avaliação da qualidade do produto a um agente externo, que seria mais bem preparado para avaliar o produto.

Para Spers (2003), a existência de assimetria de informações sugere a necessidade de intervenção estatal no monitoramento. Em uma análise mais abrangente, pode-se considerar o Sistema de Inspeção Federal (SIF) como um desses agentes, que atuam na fiscalização e manutenção de padrões de qualidade para produtos de origem animal (ECKHARDT et al, 2009). 
Segundo Kotler e Armstrong (1998, p. 96), “a empresa que realmente compreende como os consumidores respondem às diferentes características, preços e apelos de propaganda têm uma grande vantagem sobre os concorrentes".

Richers (1984) afirma que o comportamento do consumidor é caracterizado pelas atividades mentais e emocionais envolvidas na seleção, compra e uso de produtos e serviços para a satisfação de necessidades e desejos.

No Brasil, o consumo de carne suína localiza-se bastante abaixo do consumo de seus principais substitutos, que seriam os outros tipos de carne mais consumidos. Enquanto o consumo per capita de carne suína situa-se na faixa dos $13 \mathrm{~kg} / \mathrm{hab} / \mathrm{ano}$, o de carne de frango chegou a 37 kg/hab/ano, e o de carne bovina está em 36 kg/hab/ano (ANUALPEC, 2009). As razões para essa diferença de consumo são várias, desde problemas culturais, que fazem com que o consumidor brasileiro ainda acredite que o suíno seja criado de maneira inadequada e, portanto, transmita uma série de doenças aos consumidores; cuidados com a saúde e boa forma, já que se acredita que a carne de frango seja mais saudável por ser mais magra, e também menos calórica; questões econômicas, uma vez que a carne de frango é mais barata que as outras carnes; questões de adaptação às novas demandas do consumidor de alimentos, por produtos mais fáceis e práticos de preparar, e também maior variedade. Enfim, vários são os possíveis motivos para o baixo consumo de carne suína no Brasil, o que reforça a importância e a necessidade de estudar mais a fundo o consumidor para descobrir esses motivos e realizar ações que modifiquem essa situação. Assim, baseado na hipótese de que o consumidor é o principal ator de um sistema agroindustrial, e que ser capaz de oferecer-lhe o produto que ele deseja com os atributos que ele quer é a única maneira de um SAG sobreviver (SAAB, 1999; NEVES et al, 2000; SOUKI, 2003), este trabalho pretende realizar um estudo sobre o comportamento do consumidor final da carne suína no Brasil sob a ótica dos sistemas agroindustriais.

\subsection{O Problema de Pesquisa}

O problema de pesquisa que esta tese se propõe a responder é: como a carne suína e seus produtos derivados estão inseridos no estilo de vida do consumidor brasileiro de carne suína, quais são suas atitudes, valores e preferências? 


\subsection{Objetivos}

O objetivo geral deste trabalho é investigar como se comportam os consumidores de carne suína e produtos derivados no Brasil.

Para detalhar este objetivo, tem-se como objetivos específicos:

- investigar onde esses consumidores compram o produto, como compram, onde consomem, na companhia de quem consomem, com que frequência consomem, como preparam;

- analisar a satisfação do consumidor com o produto em geral, com seu sabor, suas características em relação à saúde do consumidor, a facilidade de preparo, o preço;

- analisar com quais outros alimentos a carne suína se combina no momento do consumo;

- investigar qual é a visão que o consumidor tem sobre a produção de suínos e os impactos dessa visão no consumo da carne suína e de seus derivados;

- investigar a relação entre as atitudes e valores dos consumidores e o consumo de carne suína freca e processada;

- investigar as diferenças de atitudes e valores dos consumidores de carne suína em diferentes regiões do Brasil;

- recomendar ações para a cadeia produtiva, que seriam interessantes para aumentar o consumo de carne suína e produtos derivados.

\subsection{Estrutura da Tese}

$\mathrm{O}$ que se pretendeu com este estudo foi aprofundar o conhecimento a respeito de como se comportam os consumidores de carne suína no Brasil (onde compram, como compram, onde consomem, na companhia de quem consomem, com que frequência consomem, como preparam). Analisou-se, também, a satisfação do consumidor com o produto em geral, com seu sabor, suas características em relação à saúde do consumidor, a facilidade de preparo ou conveniência, o preço, além de com quais outros alimentos a carne suína se combina no momento do consumo. 
De acordo com Serralvo e Ignacio (2004), os consumidores compram produtos com determinados atributos porque acreditam que ajudem a proporcionar certos benefícios desejados, e esses são desejados porque o consumidor crê que possam levá-lo ao alcance de certos valores. Nesse sentido, outro aspecto investigado por esta pesquisa foi a visão que o consumidor tem sobre a produção de suínos e os impactos dessa visão no consumo da carne suína e de seus derivados.

Nesta pesquisa foram estudadas ainda as variáveis comportamentais, tais como atitudes e valores do consumidor de carne suína, e possíveis diferenças com relação aos diferentes locais onde foi realizada a pesquisa (cidades grandes e pequenas das regiões sul e centro-oeste), comparando-se os resultados obtidos de modo geral com aqueles obtidos nas cidades individualmente.

Finalmente, um objetivo bastante importante do trabalho foi o de replicar parcialmente o modelo do projeto Q-PorkChains no Brasil. Trata-se de um grande projeto da União Europeia, que integra diferentes áreas do conhecimento com um objetivo comum, que é o de melhorar a carne suína para o consumidor final.

Assim, reúnem-se pesquisadores das áreas de marcadores moleculares, de genética animal, de alimentação animal, com estudiosos de cadeias e redes agroindustriais, especialistas em comportamento do consumidor e profissionais focados na união dos diferentes trabalhos, junção das áreas afins e disseminação dos objetivos atingidos no sentido de maximizar a aplicação prática e utilização dos resultados do projeto por empresas (em especial pequenas e médias empresas), universidades e institutos de pesquisa. O projeto será descrito com mais detalhes na seção 2.8 deste trabalho. 


\subsection{Introdução}

Esta seção inicia-se com uma visão geral sobre o tema Comportamento do Consumidor, expondo aspectos importantes, bem como algumas teorias que buscam explicá-lo. A seguir estuda mais especificamente a teoria cognitiva, utilizada como base teórica desta tese, descrevendo um pouco mais a fundo valores e atitudes. Há, então, uma seção específica sobre a Theory of Planned Behavior (TPB), ou Teoria do Comportamento Planejado. Há uma breve descrição do instrumento utilizado para investigar o estilo de vida do consumidor de alimentos, o Food Related Lifestyle (FRL), ou Estilo de Vida Relacionado a Alimentos. É também feita pequena revisão sobre o tema satisfação, outro assunto abordado na pesquisa aplicada.

Realiza-se, além disso, uma análise do estudo do comportamento do consumidor de alimentos, enfatizando suas diferenças em relação ao comportamento do consumidor de outros tipos de produtos. Finalizando o capítulo, descreve-se o Projeto Q-PorkChains, que foi a base da pesquisa aplicada.

\subsection{Uma Visão Geral sobre o Comportamento do Consumidor}

Uma vez que o objetivo do marketing é identificar e satisfazer as necessidades humanas e sociais dos consumidores, é fundamental conhecer seu comportamento de compra (KOTLER; KELLER, 2006, p. 4).

A pesquisa do consumidor como uma área sistemática da ciência do comportamento na forma como a conhecemos hoje teve seu início no final dos anos 1950 e começo dos anos 1960 (ENGEL et al, 1995, p. 14).

Hoppe (2010, p. 23-25) faz uma importante revisão bibliográfica sobre a definição de comportamento do consumidor, incluindo, entre outros, Solomon (2002, p. 24), que o define como "o estudo dos processos envolvidos quando indivíduos ou grupos selecionam, compram, 
usam ou dispõem de produtos, serviços, ideias ou experiências para satisfazer necessidades e desejos", e Sheth et al (2001, p. 9), que afirmam que comportamento do consumidor seria referente às "atividades físicas e mentais realizadas por clientes de bens de consumo e industriais que resultam em decisões e ações, como comprar e utilizar produtos e serviços, bem como pagar por eles".

Vários trabalhos realizados por estudiosos do marketing buscam entender por que os consumidores realizam suas escolhas (HOPPE, 2010; BARCELLOS, 2002; 2007; SHETH et al, 1991).

Antonides e Van Raaij (1998, p. 1) expõem as várias áreas para as quais o comportamento do consumidor é importante: "marketing, políticas de consumo, e para que a ciência possa testar teorias econômicas, cognitivas, econômico-psicológicas e sociopsicológicas". Sob uma perspectiva histórica, esses autores afirmam que o conceito de 'consumidor' data de apenas um século, uma vez que antes disso, em uma economia de escassez, o desafio era sobreviver e suprir necessidades básicas.

"Apenas quando sobrava alguma receita, as pessoas podiam ter a liberdade de fazer escolhas sobre como gastar ou poupar, o que passou a ocorrer com maior frequência apenas após a Segunda Guerra Mundial” (ANTONIDES; VAN RAAIJ, 1998, p. 1). No entanto, com as novas mídias interativas, os consumidores vêm adquirindo cada vez maior poder.

Hoppe (2010, p. 24) afirma ser "preciso tomar conceitos de disciplinas além do marketing para ter conhecimento sobre o comportamento do consumidor", ou seja, trata-se de um tema interdisciplinar (SOLOMON, 2002). Engel et al (1995, p. 4) definem comportamento do consumidor como "aquelas atividades diretamente envolvidas na obtenção, consumo e uso de bens e serviços, incluindo os processos decisórios que precedem e sucedem essas ações". Tal ideia é corroborada por Barcellos (2007), ao considerar o comportamento do consumidor como um processo contínuo que inclui aspectos relacionados ao antes, durante e depois do ato da compra.

Existem várias teorias que tentam explicar o comportamento de compra do consumidor. Entre elas, este trabalho irá utilizar a Theory of Planned Behavior - TPB, uma das teorias cognitivas. No entanto, procurar-se-á fazer uma breve descrição das outras, citadas a seguir. 


\subsubsection{Teoria neoclássica do comportamento do consumidor}

Esta teoria refere-se à "maneira como o consumidor aloca seus recursos entre os bens disponíveis, com base nas restrições orçamentárias, preço dos produtos e de seus substitutos, preferências individuais, entre outros aspectos" (SAAB, 1999, p. 45). Também chamada de Teoria da Racionalidade Econômica, fundamenta-se na ideia de que o consumidor é basicamente um ser racional e suas escolhas serão pautadas na busca por um maior benefício ao menor custo possível. É a chamada maximização da utilidade. Douglas (1992, p. 69) afirma que os consumidores derivam utilidade dos produtos e que esta, sujeita aos preços de bens e serviços, determina quais serão escolhidos dada a restrição orçamentária.

De acordo com Saab (1999, p. 45), tomando Y como a renda disponível e Pi o preço do bem Xi, sendo $\mathrm{i}=1,2$, n, o consumidor escolherá um conjunto de bens $\mathrm{X}^{*}$, que maximizará a função utilidade $U$, sujeito à restrição orçamentária:

$$
\begin{gathered}
\operatorname{maximizar} U=U\left(X_{1}, X_{2}, \ldots, X_{n}\right), \\
\text { sujeito a } P_{i} X_{i}=Y(1) .
\end{gathered}
$$

O conceito que resultou daí foi a teoria da utilidade marginal do valor: o consumidor continuará a comprar determinado produto enquanto a satisfação que obtiver do uso da última unidade consumida (utilidade marginal) igualar-se ou superar a utilidade marginal obtida com a mesma despesa pela compra de qualquer outro produto (STANTON, 1971, p. 101), já que seu objetivo, sujeito a uma restrição orçamentária, é maximizar a utilidade. A utilidade marginal é decrescente, e o consumidor alocará sua renda de acordo com os preços relativos dos produtos e da utilidade esperada de cada item consumido (DOUGLAS, 1992, p. 70; PINDYCK; RUBINFELD, 1994, p. 109).

Para Stanton (1971, p. 101), a principal limitação dessa teoria seria a de que ela não abrange os fatores psicológico e sociológico que influem no comportamento humano. Além disso, é difícil quantificar o grau de satisfação pessoal que resulta da posse ou do consumo de um produto. Já os compradores industriais (profissionais cuja função primordial dentro de uma empresa seria a de fazer compras), que a princípio teriam um comportamento mais racional e objetivo e, portanto, 
seriam menos influenciados por fatores psicológicos e sociológicos, poderiam oferecer uma aplicação prática de compra com base no conceito de utilidade marginal (SAAB, 1999, p. 46).

A variação de preços é outro fator que afetaria a maximização da utilidade do consumidor. Douglas (1992, p. 78), argumenta que a lei da demanda significa que "à medida que o preço aumenta, o consumidor demanda progressivamente menos do produto, e, por outro lado, à medida que o preço é reduzido o consumidor demanda progressivamente mais do produto, ceteris paribus". A variação de preços produz dois efeitos: o efeito renda e o efeito substituição.

$\mathrm{O}$ efeito renda refere-se ao aumento do poder de compra que o consumidor experimenta quando o preço de um produto que costuma consumir cai e todos os demais permanecem constantes. Isso a princípio geraria aumento no consumo do bem.

Para alguns bens, considerados inferiores, ocorre o inverso. Quando seu preço abaixa, seu consumo também diminui, sendo deslocado para o consumo do bem considerado superior. O efeito substituição indica que, quando o preço de um produto cai, os consumidores tendem a substituí-lo por outros produtos, que atendem suas mesmas necessidades.

\section{Um exemplo de aplicação no sistema carnes}

O chamado efeito substituição foi o que aconteceu, por exemplo, com as carnes para churrasco, como um dos reflexos da crise econômica mundial de 2008 (BRASIL, 2010). Com o aumento no preço da carne bovina experimentado ao final de 2008 e início de 2009, observou-se a substituição do consumo de carnes consideradas mais nobres para churrasco (picanha, por exemplo) pelo consumo de linguiça (CUNHA, 2009).

Outro aspecto econômico interessante bastante estudado com relação ao consumo de carnes refere-se à elasticidade da demanda, que seria a variação percentual em uma variável que ocorre em consequência da variação de 1\% em outra variável. Segundo Pindyck e Rubinfeld (1994, p. 35), "a elasticidade é uma medida da sensibilidade de uma variável para outra", e é geralmente um número negativo (quando o preço de um produto aumenta, a quantidade demandada, normalmente, cai).

"Elasticidade cruzada da demanda refere-se à variação percentual da quantidade demandada de uma mercadoria que resultará em $1 \%$ de aumento no preço de outra mercadoria" (PINDYCK; 
RUBINFELD, 1994, p. 39). No caso dos diferentes tipos de carnes, considerados bens substitutos, as elasticidades cruzadas são positivas, já que o aumento do preço de um produto ocasionará a elevação da quantidade demandada de outro. As carnes situam-se num grupo de alimentos que apresenta elevada elasticidade renda do consumo. Significa que o aumento de renda se reflete em geralmente elevado aumento do consumo.

Segundo projeções da Assessoria de Gestão Estratégica do Ministério da Agricultura, "a carne bovina de primeira apresenta elasticidade renda de $0,52 \%$, indicando que se a renda se elevar em $10 \%$, o consumo se eleva em 5,2\%. Para a carne de frango esse efeito é menor, pois a elasticidade renda do consumo é de 0,178" (HOFFMAN, 2007, apud BRASIL, 2010, p. 27). O estudo não apresenta o valor da elasticidade renda da carne suína.

Segundo Roppa (2008, p. 11), o consumo de carne de frango cresceu 27,67\% de 2000 a 2007 (3,3 vezes maior que o crescimento populacional, o que, segundo o mesmo autor, denota uma melhora qualitativa no padrão alimentar da população, reflexo, entre outros, de um aumento em seu poder aquisitivo), enquanto o de carne bovina foi de $9,2 \%$ no mesmo período. Com isso, pela primeira vez na história brasileira, o consumo de carne de frango ultrapassou, em 2007, o consumo de carne bovina.

Já o consumo da carne suína decresceu 6,3\% entre 2000 e 2007, passando de 14,3 para 13 kg por habitante (ROPPA, 2008, p. 11). Assim, o consumo de carne suína no país não acompanhou o crescimento populacional $(8,3 \%)$ e apresentou o menor desempenho entre todas as carnes. "Se analisarmos a evolução do consumo em termos percentuais, notaremos que, atualmente, $43 \%$ do consumo de carne no Brasil é de carne de frango, 42,2\% é de carne bovina e 14,8\% de carne suína" (ROPPA, 2008, p. 11). Isso demonstra uma mudança nas preferências do consumidor de carnes e uma gradativa substituição entre os diferentes tipos de carnes.

Uma maneira de fugir do efeito substituição é a diferenciação do produto, já que um produto com poucos substitutos tem demanda pouco elástica, ou seja, pouco afetada pelas variações em outros produtos. Na verdade, a diferenciação de produto diminui a possibilidade de substituição, e um extremo disso seria atingido quando se conseguisse tornar o produto insubstituível, criando uma curva de demanda inelástica e fazendo dele um monopolista, com capacidade de determinar preços (SAAB, 1999, p. 47).

Há ainda o impacto causado pelo aumento da renda nominal do indivíduo, quando há, necessariamente, um aumento de mesma extensão da renda real (DOUGLAS, 1992, p. 80). 
"Normalmente, isto levaria a um aumento de consumo dos bens disponíveis. Novamente, porém, aparece a questão dos bens inferiores e superiores, entre os quais isso pode variar. Com a estabilização da economia provocada pelo Plano Real, a partir de 1994, surgiu um exemplo desse fenômeno, como o aumento do consumo de iogurtes e diminuição relativa do consumo de leite, fato intensamente divulgado na mídia" (SAAB, 1999, p. 47).

Outro aspecto interessante de ser analisado seria o impacto das mudanças nos gostos e preferências do consumidor, que pode ser resultado de modas ou tendências, de investimentos em propaganda e promoção realizados por uma empresa ou um setor, ou ainda da exposição do consumidor a produtos importados. Com o exemplo do SAG do leite, Farina et al (1997, p. 208) afirmam: "Com a entrada dos lácteos importados, o consumidor das capitais é exposto a novos produtos, tornando-se mais exigente em termos de variedade, qualidade, conveniência e preços". 1

Este modelo de escolha do consumidor entre produtos possui algumas falhas que o impediram de ser mais amplamente utilizado como modelo de previsão do comportamento do consumidor. Falha, por exemplo, ao tentar explicar por que os consumidores de um produto preferem a marca A enquanto outros, a B; ou ao tentar prever um aumento das vendas quando se realiza uma mudança no produto (DOUGLAS, 1992, p. 83).

\subsubsection{Teoria comportamental}

Esta teoria enfatiza o comportamento do indivíduo e suas relações com o meio ambiente. Ao supor que o consumo é um conjunto de relações fisiológicas e comportamentais observáveis, geradas por estímulos do meio ambiente, parte-se para o estudo sistemático dos estímulos presentes no meio ambiente de consumo, que levariam o consumidor a ter reações de aproximação ou de afastamento em relação aos produtos disponíveis. Inclui, assim, a psicologia

\footnotetext{
${ }^{1}$ Uma análise mais aprofundada da teoria econômica do comportamento do consumidor pode ser encontrada em Saab (1999, p. 45-48), que inclui conceitos como análise de atributos, de Lancaster, que faz uma importante interface com a administração, e também conceitos de fronteira de eficiência e curva de indiferença.
} 
como uma alternativa para a compreensão dos fatores cognitivos, motivacionais, bem como os emocionais, envolvidos nos processos de escolha e decisão de compra (PINHEIRO; CASTRO, 2006).

\subsubsection{Teoria psicanalítica}

Segundo esta teoria, o consumo seria uma tentativa de o consumidor dar vazão a seus desejos, expectativas, angústias e conflitos por meio dos produtos. Utiliza a psicanálise, criada pelo neurologista austríaco Sigmund Freud (1856-1939) no final do século XIX e início do século $\mathrm{XX}$, para descobrir o que acontece no íntimo do consumidor no momento da compra. Analisando a mente humana como possuidora de uma esfera consciente e outra inconsciente, afirma que esta última exerce uma forte influência sobre a primeira, e, assim, os comportamentos expressos na consciência são uma expressão de desejos localizados no inconsciente. Portanto, “o significado de um comportamento ou de uma atitude não deve ser buscado no plano consciente, mas nos motivos ocultos que estão situados no plano do inconsciente" (PINHEIRO; CASTRO, 2006, p. 18, apud NASCIMENTO, 2008).

\subsubsection{Teorias social e antropológica}

São teorias que enfocam o consumo como um processo social, ressaltando seus condicionantes históricos, sociais e culturais, com a ideia básica de que os consumidores adotam certos comportamentos de consumo visando integrar-se a seu grupo social. Assim, os consumidores agiriam no sentido de parecer-se com os indivíduos de seu grupo de referência e diferenciar-se de outros.

Essas teorias dividem-se em duas grandes vertentes: uma baseada nos conceitos marxistas e outra, em pesquisas sobre os hábitos de consumo das sociedades contemporâneas.

Nas estratégias de comunicação de marketing, esta teoria é aplicada nos anúncios que envolvem testemunhos de pessoas famosas ou de reconhecido prestígio, com a ideia de que o indivíduo irá 
comprar o produto para parecer-se com os líderes de opinião e ser aceito no grupo social, ou quando se informa o consumidor de que esse produto é o que todos compram.

Também pode acontecer o processo contrário: os indivíduos comportam-se de forma a se diferenciarem do resto do grupo. No entanto, a ideia é basicamente a mesma: conseguir destaque dentro do grupo.

\subsection{Teoria Cognitiva}

Esta tese irá utilizar a Teoria Cognitiva porque ela possibilita uma visão mais integrada de produto, consumidor e ambiente, em uma visão do consumo como um processo de tomada de decisão, tendo como pano de fundo a influência de fatores cognitivos, como percepção, motivação, aprendizagem, memória, atitudes, valores e personalidade, além do estilo de vida dos consumidores.

Também exercem influência no comportamento de compra os valores socioculturais, como o poder do grupo, da família, da cultura e da classe social, e também os valores situacionais, como a influência do meio ambiente (ambientação de loja, displays no ponto de venda, posição dos produtos nas gôndolas) no momento da compra (PINHEIRO; CASTRO, 2006).

Para Solomon (2002), as pessoas compram um produto por seu significado e não por aquilo que ele faz. Grunert, que tem vários estudos realizados na área do comportamento do consumidor de alimentos $(2002 ; 2004 ; 2005 ; 2006 ; 2007 ; 2008)$, afirma que a percepção da qualidade do alimento ocorre após sua compra, preparo e consumo.

\subsubsection{Fatores de influência no processo de decisão de compra}

Engel et al (2000) afirmam que existem algumas variáveis que influenciam o processo de decisão de compra do consumidor e dividem-nas em influências ambientais, diferenças individuais e fatores pessoais. Churchill e Peter (2000) separam-nas em influências sociais e situacionais, e Solomon (2002) afirma que o consumidor sofre influências psicológicas, pessoais, 
sociais e culturais. Estudos (ENGEL et al, 2000; CHURCHILL; PETER, 2000; SOLOMON, 2002; KOTLER; KELLER, 2006) afirmam que há vários fatores internos e externos que influenciam o processo de decisão de compra e, ainda que não possam controlá-los, é necessário que a empresa e os profissionais de marketing os levem em consideração (KOTLER; ARMSTRONG, 1995, p. 97). Entre esses fatores, podem-se citar alguns, ilustrados na Figura 1.

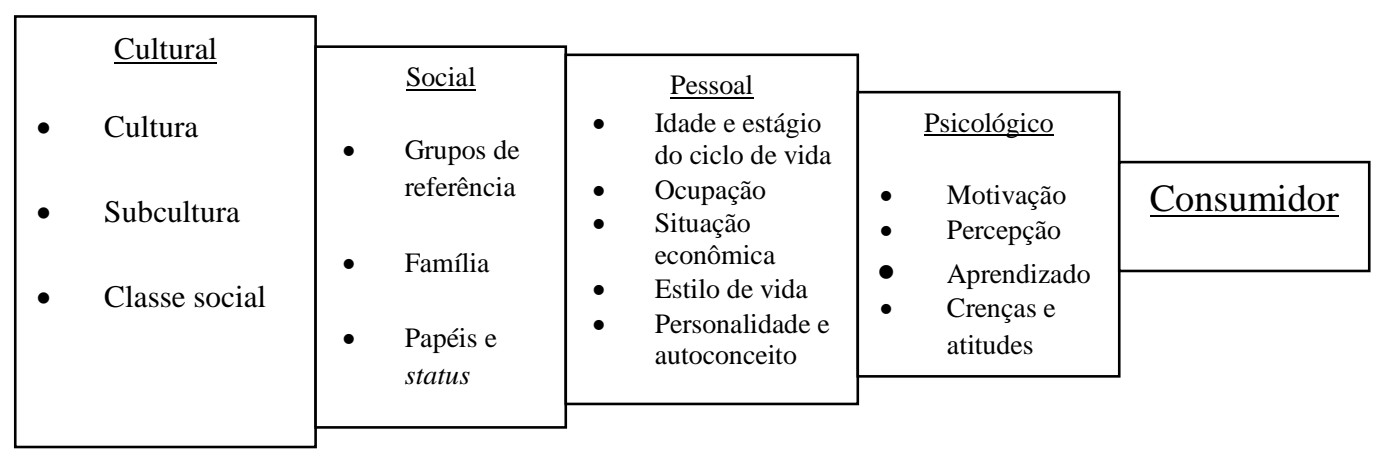

Figura 1 - Fatores que influenciam o comportamento do consumidor FONTE: Kotler e Armstrong, 1995, p. 97.

\section{A. Fatores culturais}

Segundo Kotler e Keller (2006), os fatores culturais são aqueles que exercem a maior e mais importante influência sobre os consumidores e dividem-se em: cultura, subcultura e classe social.

\section{A.1. Cultura}

Refere-se ao "conjunto de valores, percepções, preferências e comportamentos através da vida familiar e de outras instituições básicas que acabam, logicamente, interferindo em seus hábitos de consumo presentes e futuros" (MEDEIROS; CRUZ, 2006, p. 170). Segundo Kotler (1998, p. 162), "a cultura é o determinante mais fundamental dos desejos e do comportamento de uma pessoa". Cabe aos estudiosos do comportamento do consumidor localizar as constantes mudanças culturais para descobrir novos produtos que possam ser desejados pelos consumidores (KOTLER; ARMSTRONG, 1995, p. 97), bem como novos atributos que devam ser adicionados ou retirados dos produtos a fim de oferecer ao consumidor o que ele deseja consumir.

Segundo Barcellos (2007, p.58), "o consumo das carnes é permeado não apenas por aspectos fisiológicos (e ancestrais), mas também por influências culturais e psicossomáticas". 


\section{A.2. Subcultura}

Inclui conceitos como nacionalidade, religião, grupo racial e região geográfica. Para Kotler (1998, p. 162), cada cultura possui dentro de si divisões, chamadas de subculturas, que oferecem identificação mais específica e socialização entre seus participantes.

Vários estudos têm sido feitos comparando aspectos entre diferentes países, no sentido de verificar a importância dessas diferenças culturais e o quanto elas influenciam o comportamento de consumo (OLSEN et al, 2007; BARCELLOS, 2007; HOUSTON, 2004; VERBEKE, 2005).

\section{A.3. Classe social}

Segundo Kotler (1998, p. 163), “classes sociais são divisões relativamente homogêneas e duradouras de uma sociedade, que são ordenadas hierarquicamente e cujos membros compartilham valores, interesses e comportamentos similares".

\section{B. Fatores Sociais}

Há ainda os fatores sociais, como grupos de referência, família, papéis e posições sociais, que influenciam o comportamento de compra (KOTLER; KELLER, 2006).

\section{B.1. Grupos de referência}

São os grupos que servem de pontos de comparação na formação de atitudes ou comportamentos de uma pessoa (KOTLER; ARMSTRONG, 1995, p. 99). Segundo Kotler (1998, p. 164), existem grupos de afinidade chamados de "primários" - a família, os amigos, os vizinhos e os colegas de trabalho -, que são informais e com quem as pessoas interagem mais continuamente.

Além disso, existem os grupos de afinidade chamados de "secundários", formados pelas religiões, sindicatos e grupos ligados às profissões das pessoas, que tendem a ser mais formais e exigir menor interação. Já para Churchill e Peter (2000, p. 160), “os grupos de referência são aqueles grupos de pessoas que influenciam os pensamentos, os sentimentos e os comportamentos do consumidor".

Schiffman e Kanuk (2000) definem ainda o que chamam de "grupos de aspiração", que seriam aqueles aos quais a pessoa gostaria de pertencer, mas dos quais não são membros. Esses grupos, 
segundo os autores, também exercem influência sobre o comportamento de compra dos consumidores. Além desses, há os "grupos de negação", que são os grupos repudiados.

Para Churchill e Peter (2000), na maior parte dos casos, esses grupos de referência não dizem diretamente aos consumidores o que fazer, e sua influência ocorre porque os consumidores se preocupam com os sentimentos dos membros do grupo, deixando-se influenciar por suas opiniões. Olsen et al (2007) realizaram um estudo em que relacionam a conveniência, a alimentação e grupos de referência.

\section{B.2. Família}

Este constitui, segundo Kotler e Keller (2006, p. 177), o grupo primário de referência de maior influência. Podem-se distinguir duas famílias: a de "orientação", que é formada pelos pais, e a de “procriação", por esposa e filhos. No entanto, a organização familiar tradicional está diminuindo e, à medida que isso acontece, as pessoas estão colocando ênfase ainda maior em irmãos, amigos íntimos e outros familiares para ter companhia e apoio social (SOLOMON, 2002). Dessa maneira, descobrir os papéis de cada membro na compra de determinado bem/serviço pode ser o item de maior importância para as empresas permanecerem competitivas no mercado (KOTLER; KELLER, 2006).

\section{B.3. Papéis e posições sociais ou status}

Para Churchill e Peter (2000, p. 160), pessoas de diferentes classes sociais farão escolhas diferentes em relação a roupas, decoração, uso do tempo de lazer, padrões de gastos e poupanças e escolha dos meios de comunicação.

Ao longo de suas vidas, as pessoas assumem diferentes papéis e posições sociais, de acordo com o grupo social a que estejam ligados, e com base neles procurarão produtos que comuniquem seu status na sociedade (KOTLER, 1998).

\section{Fatores Pessoais}

O momento pessoal e a vivência pela qual um indivíduo esteja passando interferem em seus hábitos e decisões de consumo. Kotler (1998) apresenta cinco elementos que constituem os fatores pessoais: idade e estágio do ciclo de vida, ocupação, condições econômicas, estilo de vida e personalidade. 
C.1. Idade e estágio do ciclo de vida

Para Kotler (1998, p. 168), “as necessidades e os desejos das pessoas modificam-se ao longo de suas vidas". Nesse sentido, Churchill e Peter (2000, p. 162) comentam a existência dos ciclos de vida familiar, isto é, “conjunto de estágios pelos quais as famílias passam e que influenciam suas necessidades e a capacidade de satisfazê-las".

\section{C.2. Ocupação}

Diz respeito à profissão que o consumidor exerce. "Um presidente de empresa comprará ternos caros, passagens aéreas, títulos de clube, um grande veleiro”, exemplifica Kotler (1998, p. 169), ou seja, o trabalho dos consumidores influencia seus padrões de consumo.

\section{C.3. Situação econômica}

Segundo Kotler (1998), fatores como a renda disponível, poupança e patrimônio, condições de crédito, atitudes em relação às despesas versus poupança, afetam diretamente a escolha de produtos. Faria et al (2006) afirmam que a renda familiar tem grande influência na preferência do consumidor por determinado tipo de carne, tendo constatado em pesquisa realizada na cidade de Belo Horizonte que "a carne suína é preferida pela população na faixa de até três SM".

\section{C.4. Estilo de vida}

"É o padrão de vida expresso em termos de atividades, interesses e opiniões" (MEDEIROS; CRUZ, 2006, p. 173). Para Kotler (1998), é possível que empresas se posicionem no mercado através de associações entre seus produtos e o estilo de vida de seus consumidores reais e potenciais.

Com o fim específico de aplicar o estudo de estilos de vida dos consumidores ao consumo de alimentos, foi criado o Food Related Lifestyle (FRL), um dos instrumentos utilizados na construção do questionário desta pesquisa, o qual será mais bem descrito posteriormente, na seção 2.5 deste trabalho.

\section{C.5. Personalidade e autoconceito}


"A personalidade de um indivíduo é composta de uma multiplicidade de componentes que incluem valores, atitudes, crenças, motivos, intenções, preferências, opiniões, interesses, preconceitos e normas culturais" (RICHERS, 1984, p. 49). Para Kotler (1998), a personalidade é uma variável importante para análise do comportamento do consumidor. É necessário, no entanto, classificar tipos de personalidade e estabelecer correlações fortes entre eles e certas escolhas de produto ou marca.

Nesse sentido, Jung (1974) identifica características que determinam tipos de personalidades, conhecidas como "personalidades junguianas", que seriam:

a) Sentimento - Pensamento (ST). Trata-se de um ser que é racional ao tomar decisões; avalia fortemente considerações econômicas, sendo, portanto, muito sensível a preços. Ele normalmente irá fazer um considerável esforço para obter informações para tomar decisões e evita correr riscos. Para esse tipo, o materialismo reflete motivo pessoal ou particular.

b) Sentimento - Emoção (SF). Pessoa que toma decisões seguindo uma orientação "subjetiva"; usualmente tem possibilidade de considerar outros quando toma decisões. Para ela, o materialismo reflete como os objetos irão impactar outros.

c) Intuição - Pensamento (NT). Pessoa que tem ou teria uma visão ampla da situação pessoal; que pesa suas opções mentalmente; e que está sempre pronta para assumir risco ou ser especulativa nas decisões.

d) Intuição - Emoção (NF). Ser que imagina uma ampla faixa de opções ao tomar as decisões; é altamente "orientado para pessoas", ou seja, tem possibilidade de considerar a opinião dos outros; que toma as decisões seguindo uma orientação subjetiva. Dentre todos os tipos descritos por Jung, é o menos sensível a preço e normalmente busca o risco (quer aventura e novidade) (MEDEIROS; CRUZ, 2006, p. 174).

\section{Fatores psicológicos}

Para que um consumidor tome a decisão de compra, é preciso que em sua mente se desenvolvam os seguintes estados: existência de uma necessidade, consciência dessa necessidade, conhecimento do objeto que pode satisfazê-la, desejo de satisfazê-la e decisão por determinado produto (SANT'ANNA, 1989). 
Kotler e Keller (2006, p. 191) explicam alguns conceitos importantes na busca de entender os processos de avaliação de alternativas do consumidor em relação aos produtos disponíveis. Para esses autores, o consumidor está tentando satisfazer uma necessidade e buscando certos benefícios na escolha do produto. Além disso, ele vê o produto como um conjunto de atributos que tem diferentes capacidades de oferecer os benefícios necessários para atender ou satisfazer dada necessidade. Os autores descrevem o modelo de expectativa em relação ao valor, no qual o consumidor toma atitudes com base em suas crenças sobre como cada uma delas se posiciona em relação a cada atributo.

Nesse sentido, segundo Kotler (1998), existem quatro importantes fatores psicológicos que influenciam as escolhas dos consumidores: motivação, percepção, aprendizagem e crenças e atitudes.

\section{D.1. Motivação}

É a força interna, produzida quando há uma necessidade insatisfeita (SHIFFMAN; KANUK, 2000), que move os indivíduos e os impele à ação. Normalmente é gerada por um estado de tensão e, de acordo com Kotler (1998, p. 173), "um motivo ou impulso é uma necessidade que está pressionando suficientemente para levar uma pessoa a agir”.

Para Schiffman e Kanuk (2000), a motivação é a força motriz interna dos indivíduos que os impele à ação, a qual é produzida por um estado de tensão, que existe uma vez que há uma necessidade não satisfeita.

A administração de marketing, de acordo com Kotler e Keller (2006, p. 183-184), considera três teorias da motivação:

a) teoria da motivação de Freud: ele assumiu que as forças psicológicas reais que moldam o comportamento das pessoas são inconscientes e que, à medida que crescem, as pessoas reprimem muitos de seus impulsos, os quais, no entanto, nunca são eliminados ou completamente controlados (KOTLER; ARMSTRONG, 1995, p. 103). Sugere, portanto, que ninguém chega a compreender por completo suas motivações. "Embora as conclusões da pesquisa motivacional possam às vezes parecer meio estranhas, ela continua sendo uma ferramenta útil para os profissionais de marketing compreenderem melhor o comportamento do consumidor" (KOTLER; ARMSTRONG, 1995, p. 103). 
b) teoria da motivação de Maslow: para ele, as necessidades humanas são organizadas em uma hierarquia, partindo das mais às menos urgentes, ou seja, as pessoas têm necessidades específicas em momentos específicos. Maslow chegou a essa conclusão buscando responder por que as pessoas são dirigidas por certas necessidades em ocasiões específicas. Em ordem de importância, são necessidades fisiológicas, de segurança, sociais, de autoestima e de autorrealização. A pessoa tenderá a satisfazer em primeiro lugar a necessidade mais premente, a qual, depois de satisfeita, deixará de ser motivadora e dará lugar a uma segunda necessidade mais premente, que entrará então em ação (KOTLER; ARMSTRONG, 1995, p. 103).

c) teoria da motivação de Herzberg: ele desenvolveu a teoria dos dois fatores: insatisfatórios (aqueles que causam a insatisfação) e satisfatórios (aqueles que causam a satisfação). São duas as implicações de tais teorias: primeiro, devem-se evitar os fatores que causam a insatisfação; depois, identificar os fatores que causam a satisfação (MEDEIROS; CRUZ, 2006, p. 175).

\section{D.2. Percepção}

Kotler e Armstrong (1995, p. 103) dizem que, quando uma pessoa se encontra motivada, está pronta para agir. Nesse sentido, "percepção é a forma pela qual uma pessoa seleciona, organiza e interpreta as informações para criar um quadro significativo do mundo". Schiffman e Kanuk (2000, p. 103) definem percepção como “o processo pelo qual um indivíduo seleciona, organiza e interpreta estímulos visando a um quadro significativo e coerente do mundo".

Segundo Kotler e Keller (2006, p. 184), para o marketing, “as percepções são mais importantes do que a realidade, visto que é a percepção que de fato influencia o comportamento de compra do consumidor".

Kotler (1998, p. 175) descreve três processos de percepção:

a) atenção seletiva: o autor diz que é mais provável as pessoas perceberem estímulos relacionados a uma necessidade atual, bem como é mais provável que percebam estímulos já previstos e estímulos cujos desvios sejam maiores em relação a um estímulo normal;

b) distorção seletiva: as pessoas tendem a interpretar as informações conforme suas intenções pessoais, mais reforçando suas pré-concepções do que contrariando-as;

c) retenção seletiva: refere-se à tendência de as pessoas reterem as informações que confirmem suas atitudes e crenças. 
Kotler e Keller (2006, p. 185) fazem referência a outro tipo de percepção que vem sendo estudado por teóricos do marketing, que é a percepção subliminar: “Apesar de os consumidores não terem consciência dessas mensagens, elas afetam seu comportamento".

\section{D.3. Aprendizado}

São aquelas mudanças que ocorrem no comportamento de um indivíduo e foram originadas em suas experiências (KOTLER, 1998, p. 175; KOTLER; ARMSTRONG, 1995, p. 105). Refere-se à possibilidade de se desenvolver a demanda por um produto pela associação dele a impulsos fortes, usando sugestões motivadoras e oferecendo reforço positivo.

Richers (1984, p. 50) salienta que "o homem é capaz de aprender e alterar seus comportamentos através da ampla utilização de sua experiência passada". Apresenta ainda duas explicações psicológicas para a natureza do aprendizado: a cognitiva (por meio da qual o indivíduo se conscientiza de um estímulo) e a afetiva (que ocorre quando alguém começa a apreciar o estímulo após tornar-se consciente dele).

\section{D.4. Crenças e Atitudes}

O homem, como indivíduo, é dotado de razão e personalidade única. Nesse sentido, segundo Kotler (1998, p. 176), "crença é um pensamento descritivo que uma pessoa sustenta sobre algo", ou ainda "um pensamento descritivo da pessoa sobre alguma coisa" (KOTLER; ARMSTRONG, 1995, p. 105).

Para Mowen e Minor (2003), as crenças têm sua origem na aprendizagem cognitiva e no processamento de informações, uma vez que estão associadas ao conhecimento que as pessoas têm a respeito dos objetos. Estes são as coisas sobre as quais os indivíduos possuem opiniões. Também atuam na formação das crenças as características desses objetos (atributos, qualidade, aspectos) e seus benefícios (os resultados advindos dos objetos). Nem sempre as crenças serão verdadeiras.

Outro ponto a ser considerado na formação das crenças é que em geral as pessoas atribuem maior importância às informações negativas do que às positivas no processo de aprendizado a respeito de um determinado objeto, o que pode servir como um processo de viés da realidade (AJZEN, 2001). 
Tão importantes quanto as crenças, são as atitudes. Kotler e Armstrong (1995, p. 105) afirmam que estas colocam as pessoas numa estrutura mental de gostar ou desgostar das coisas, de aproximar-se ou afastar-se delas. Ainda, como afirma Solomon (2002, p. 165), "uma atitude é duradoura porque tende a persistir ao longo do tempo". Além disso, as atitudes seguem um padrão e é difícil mudá-las (KOTLER; ARMSTRONG, 1995, p. 105). "Uma atitude corresponde a avaliações, sentimentos e tendências de ação duradouros, favoráveis ou não, a algum objeto ou ideia" (KOTLER; KELLER, 2006, p. 191).

Por tratar-se de uma definição extremamente importante para o desenvolvimento do trabalho, o fator psicológico ‘atitude’ será abordado de modo mais aprofundado na próxima seção.

\subsubsection{Valores e atitudes}

Os valores formam a base de grande parte da percepção e do comportamento humano. Um exame dos valores fornece um quadro geral das noções mais abstratas do indivíduo e é uma maneira de unir crenças centrais e atitudes. Como servem como padrões de conduta, tendem a ser de número limitado, universais entre culturas diferentes, estáveis ao longo do tempo e podem servir como bons preditores do comportamento de um indivíduo por grandes períodos de tempo. Assim, os valores são comumente tidos como o ponto de intersecção entre o indivíduo e a sociedade, porque ajudam a conhecer e entender o mundo interpessoal e guiar a adaptação do indivíduo às condições a seu redor.

De acordo com Brunso et al (2004), valores humanos têm sido definidos como conceitos ou crenças abstratas que representam os objetivos desejados ou estados-finais (ROCKEACH, 1968; SCHWARTZ; BILSKY, 1987). Sendo assim, constituem o mais abstrato nível de cognição, não específico com relação a situações ou objetos, mas influenciando a percepção e avaliação dos mesmos. Presume-se, então, que valores sejam o critério utilizado pelas pessoas como guias para avaliar os estímulos, ou seja, situações, pessoas e objetos.

Em geral assume-se que os valores são universais no sentido de que as pessoas perseguem os mesmos valores no mundo todo, mas a importância relativa de cada um deles varia (ROCKEACH, 1973; SCHWARTZ; BILSKY, 1987). De acordo com esse entendimento geral, podem-se citar as principais afirmações para descrever sistemas de valores: valores são conceitos 
ou crenças sobre objetivos desejáveis que transcendem situações específicas, guiam a seleção ou avaliação de comportamentos ou eventos, e são ordenados por importância (SCHWARTZ, 1992).

O estudo das atitudes é extremamente relevante para que se possam compreender melhor os aspectos referentes ao comportamento do consumidor. A fim de compreender muitos dos aspectos relacionados ao comportamento de compra do consumidor, torna-se bastante importante fazer uma análise de suas atitudes (KARSAKLIAN, 2000).

Segundo Shiffman e Kanuk (2000, p. 165), "considerando o contexto do comportamento do consumidor, uma avaliação das atitudes predominantes tem um importante mérito estratégico".

Assim, uma vez que um indivíduo tenha uma atitude positiva em relação a determinado objeto, apresentará uma tendência a aceitar - no caso de produtos, consumir - de forma mais favorável esse mesmo objeto. Tal ideia pode ser ampliada de maneira que, uma vez que se conheçam as atitudes de um indivíduo, pode-se tentar inferir sobre seu comportamento em relação aos objetos desta atitude (DONEGÁ, 2004, p. 15).

Greenwald (1989) aponta a importância de identificar e medir as atitudes, considerando-as como uma força seletiva para percepção e memória dos indivíduos, servindo a várias funções psíquicas; dessa forma, as atitudes podem ser um dos fatores que auxiliam a "prever" o comportamento dos indivíduos em função de seus objetos.

Quando o indivíduo tem uma atitude específica em relação a algo, baseia-se em algum conhecimento ou crença sobre esse objeto, transformando esse conhecimento ou crença em sentimentos positivos ou negativos em relação a ele e, finalmente, esboçando uma tendência a alguma ação (SHETH et al, 2001).

Para Donegá (2004, p. 15), quando um indivíduo decide, por exemplo, qual a marca ou em que loja comprar, sua escolha irá basear-se, entre outros fatores, nas avaliações (favoráveis ou desfavoráveis) que tem em relação ao objeto (neste caso, a marca ou a loja, ou ainda ambos). Assim, entender e medir atitudes são maneiras de identificar por que os indivíduos fazem determinadas escolhas ou escolhem determinados objetos.

De acordo com o mesmo autor, as atitudes podem também ser usadas para julgar os resultados de uma campanha publicitária que tenha por objetivo principal aumentar as vendas de determinada empresa, ou de determinado produto. As vendas podem aumentar somente devido à campanha e durante sua vigência, voltando aos patamares anteriores após o término do esforço de vendas 
relacionado à campanha. Isso denota que não houve uma mudança efetiva de atitude do consumidor frente ao produto, mas uma mudança temporária de comportamento de compra que pode estar ligada a vários fatores, entre eles a facilidade de aquisição, a disponibilização do produto no ponto de venda ou ainda a maior variedade de produtos e maior conveniência em sua aquisição e preparo.

Isso foi claramente o que ocorreu em alguns locais onde foi realizada a campanha "Um Novo Olhar Sobre a Carne Suína”, levada a efeito pela Associação Brasileira dos Criadores de Suínos (ABCS). Verificaram-se aumentos expressivos no consumo do produto durante a realização da campanha, acompanhados por quedas abruptas logo após seu término (ARGUMENTO SUÍNO, 2006). Assim, é preciso investigar os impactos da propaganda sobre o público-alvo, verificando se esta despertou uma atitude positiva ou não, de forma a testar sua verdadeira eficácia (FARIA et al, 2006).

O desempenho ambiental responsável e sustentável é outro fator que influencia as atitudes do consumidor, uma vez que, com relação ao processo de produção, serão valorizados aqueles produtos e marcas que garantam que, em toda a cadeia produtiva, tenham ocorrido impactos negativos sobre o meio ambiente (SOUKI, 2003). E o consumidor está cada vez mais informado e consciente quanto a esses impactos.

Muitos consumidores acabam desenvolvendo atitudes mais favoráveis a embalagens mais práticas ou ecologicamente corretas entre outros fatores, sendo bastante interessantes os estudos de mercado referentes ao lançamento de novos produtos ou de novas embalagens (MESTRINER, 2002).

Segundo Kotler (2000), uma empresa pode direcionar de forma muito mais efetiva seus esforços de marketing a um segmento de mercado que se apresente favorável em relação a seus produtos e serviços.

No Brasil, as empresas do setor de alimentos passam hoje por grandes transformações que partem de seu elemento-chave, que é o consumidor final (NEVES et al, 2000). Entender as mudanças nos desejos desse novo consumidor, que vem alterando gradativamente seus hábitos alimentares, torna-se cada vez mais vital para que se possa compreender como as empresas, ao longo das cadeias produtivas, devem trabalhar para atingir seus objetivos.

Assim, o varejo de alimentação, as empresas do setor de serviços de alimentação, os distribuidores atacadistas, a indústria de alimentos, a agroindústria, a produção agropecuária e as 
empresas de insumos precisam crescentemente fazer fluir eficientemente as informações ao longo da cadeia produtiva a fim de compreender o que o consumidor final demonstra em termos de preferência alimentar e, consequentemente, como e o que irá comprar (MOURA et al, 2009, p. 40-41).

Verbeke (2005) afirma que não somente as características sociodemográficas, mais comumente usadas em pesquisa para justificar as diferenças de comportamento de compra entre indivíduos, mas também o conhecimento, as atitudes e as crenças podem explicar grande parte das variações no processo de compra de alimentos.

Para Myers (2000, p. 72), “as atitudes irão prever o comportamento [...] quando especificamente são relevantes para o comportamento observado". No caso da carne suína, presume-se que a atitude que o consumidor tenha em relação ao produto e, antes dele, ao animal de onde vem o produto tenha influência sobre seu comportamento de consumo.

Assim, as melhorias que vêm sendo feitas ao longo da cadeia produtiva devem continuar no sentido de obter-se um produto cada vez mais saudável, sem resíduos de antibióticos, medicamentos e anabolizantes e com menor teor de gordura e colesterol, rico nutricionalmente e com elevado valor proteico (MOURA et al, 2009, p. 40).

De acordo com Mowen e Minor (2003), a atitude seria "a quantidade de afeição ou sentimento a favor ou contra um estímulo". Tal conceito decorre daquele empregado por Fishbein e Ajzen (1975).

Solomon (2002, p. 165) define atitude como "uma avaliação geral e duradoura de pessoas (incluindo elas próprias), objetos, anúncios e questões", afirmando ainda que "uma atitude é duradoura porque tende a persistir ao longo do tempo, e é geral porque se aplica a mais de um evento momentâneo".

Para Donegá (2004, p. 16), é extremamente importante estudar atitudes sob uma abordagem ampla do comportamento do consumidor, já que, uma vez que se tenha entendido e, preferencialmente, medido as atitudes, pode-se deduzir que se possa compreender melhor o porquê das ações dos consumidores, ou seja, como fazem suas escolhas em relação aos objetos.

A tendência de agir de "certa forma" e a ação podem ser refletidas como uma intenção de comportamento ou o próprio comportamento do indivíduo; e, se as atitudes podem ser identificadas e avaliadas, logo o comportamento do indivíduo pode ser influenciado ou até mudado. 


\subsubsection{A formação das atitudes}

Shiffman e Kanuk (2000, p. 167) afirmam que atitude é "umapredisposição, que se aprende, a se comportar de maneira constantemente favorável ou desfavorável a respeito de um dado objeto". Complementando este conceito e em concordância com o conceito apresentado por Fishbein e Ajzen (1975), Sheth et al (2001, p. 367) afirmam que as "atitudes formam-se com base em alguma experiência com um objeto ou uma informação sobre ele, [...] residem na mente e precedem e produzem o comportamento", e ainda afirmam, como Engel et al (1995, p. 362), que as atitudes são "simplesmente uma avaliação geral" feita pelo consumidor, indicando se este gosta ou não gosta de alguma coisa.

Desta maneira, para Hawkins et al (2007), atitude seria uma predisposição em comportar-se de determinada forma (favorável ou não) em relação a um determinado objeto, por meio da organização de processos cognitivos, emocionais e motivacionais. Já que as atitudes são formadas a partir das crenças, quaisquer mudanças nessas últimas deverão, a princípio, gerar mudanças nas primeiras. São essas crenças que prevalecem na formação das atitudes das pessoas (AJZEN; FISHBEIN, 2000).

Ao relacionar atitudes e comportamento, Antonides e Raaij (1998, p. 203) afirmam que "a atitude sozinha tem menor valor preditivo que a intenção comportamental”" ${ }^{2}$ E citam Ajzen e Fishbein (1980), que, em seu modelo, incluem a influência da norma social juntamente com a atitude. Esses autores (AJZEN; FISHBEIN, 1980) assumem que os indivíduos são racionais e fazem uso sistemático da informação disponível, considerando as implicações de suas ações antes de decidir realizar ou não um determinado comportamento.

Para Kotler e Keller (2006, p. 195), importantes ainda são os fatores que podem interferir entre a intenção e a decisão de compra: as atitudes dos outros, que dependerão basicamente da intensidade da atitude negativa da outra pessoa em relação à opção escolhida pelo consumidor e da motivação do consumidor em acatar as opiniões da outra pessoa. "Quanto mais intenso o negativismo da outra pessoa e quanto mais próxima ela for do consumidor, mais este ajustará sua intenção de compra" (KOTLER; KELLER, 2006, p. 195).

\footnotetext{
2 "The attitude alone has less predictive value than the behavioral intention."
} 
O papel dos intermediários da informação surge aí como altamente impactante, e alguns atores importantes podem ser citados como fatores de interferência ao se estudar o consumo de alimentos: médicos, nutricionistas, professores de educação física. À medida que tais profissionais comunicam suas avaliações a respeito de determinados produtos alimentares a seus pacientes e clientes, eles provavelmente exercerão algum grau de influência na tomada de decisão de compra desses mesmos clientes e pacientes (MAHON et al, 2006).

Há ainda os fatores situacionais imprevistos, que podem alterar a situação de compra (como a imprevista diminuição da renda do consumidor, a necessidade de usar o recurso que seria utilizado para realizar a compra, para outro fim), ou ainda a existência de risco percebido, que pode ser funcional, físico, financeiro, social, psicológico ou de tempo (KOTLER; KELLER, 2006, p. 195-196).

De acordo com Canton et al (1989), no processo de compra os consumidores procedem de maneiras diferentes em relação a diferentes produtos e marcas. Além disso, o processo de escolha e modo de agir dos consumidores também sofre influência de fatores culturais, sociais, pessoais, psicológicos, econômicos e outros (KOTLER; KELLER, 2006). O envolvimento dos consumidores com o processo de compra dos produtos depende de fatores que podem influenciálo isoladamente ou em conjunto: preço, ocasião de uso, percepção de riscos, interesse, visibilidade social e valor simbólico do produto (CANTON et al, 1989; KARSAKLIAN, 2000).

Tal envolvimento afeta diretamente o comportamento dos consumidores, uma vez que, para os mesmos autores, um consumidor altamente envolvido procura muitas informações e analisa-as com mais cuidado. Já em relação aos riscos, sua percepção e envolvimento no processo de compra são diretamente proporcionais, isto é, quanto maior for a percepção de risco, maior será o envolvimento do consumidor e vice-versa (BARCELLOS, 2007).

Isso ocorre em função das possíveis consequências negativas advindas de uma compra malfeita, mesmo que o produto tenha um preço baixo (CANTON et al, 1989), situação bastante comum no caso de alimentos. Por isso, muitas vezes os consumidores compram produtos mais caros com o objetivo de reduzir a sensação de risco (SHAPIRO, 1986).

Katz (1960) criou a chamada teoria funcional da atitude, que sustenta que os indivíduos têm certas atitudes - ou vêm a adquiri-las - porque estas servem para algumas funções no sentido de facilitar o comportamento social. Assim, quando um indivíduo tiver de lidar com uma situação já vivenciada em relação a um objeto, passará a formular previamente atitudes em relação a ela. 
Da mesma maneira como se estudam os atributos de crença que conferem confiabilidade a selos, por exemplo, como no caso dos produtos orgânicos (HOPPE, 2010), a existência de uma marca forte pode garantir esses mesmos atributos. Spers et al (2007) realizaram um estudo no qual montaram um mapa hierárquico de valor para o atributo certificação. Tal mapa poderia ser transportado para outros tipos de produto no setor de alimentos para os quais, assim como o produto orgânico, não seja possível observar a presença de determinados atributos.

Donegá (2004, p. 22), com base em Sheth et al (2001) e Solomon (2002), expõe algumas funções das atitudes:

a) função utilitária: relacionada à utilidade do objeto, baseada em princípios que relacionam o objeto a algum tipo de recompensa ou punição. O indivíduo forma uma atitude em relação a um determinado objeto na expectativa de que uma ação favorável em relação ao objeto resulte, por exemplo, em algo prazeroso;

b) função expressiva de valor: função relacionada à manifestação de todos os valores centrais do indivíduo ou seu autoconceito. O indivíduo forma uma atitude em relação a determinado objeto de forma a manifestar seus valores por meio da aceitação ou negação ao objeto;

c) função defensiva do ego: função relacionada à defesa do ego, defendendo o indivíduo contra ameaças externas ou sentimentos internos. O indivíduo forma uma atitude em relação a um determinado objeto de forma que a aceitação ou negação ao objeto crie uma situação que proteja o indivíduo de fatores que, segundo sua concepção, são ameaças ou sentimentos que o incomodam;

d) função de conhecimento: função relacionada ao acréscimo de conhecimento que o indivíduo tem, dadas a aceitação ou a negação do objeto. O indivíduo forma uma atitude em relação a determinado objeto de modo que o resultado implique alguma estrutura ou significado para ele.

Solomon (2002, p. 166) afirma que "uma atitude pode servir a mais de uma função, mas em muitos casos uma especificamente será dominante". 
Para Sheth et al (2001), a formação e mudança das atitudes do indivíduo abrangem principalmente os seguintes grupos de teorias: teoria do aprendizado, teoria da atribuição e teorias de consistência cognitiva.

As teorias do aprendizado abordam o método de condicionamento clássico, condicionamento instrumental, moldagem e teoria cognitiva da aprendizagem (SHIFFMAN; KANUK, 2000; SHETH et al, 2001; SOLOMON, 2002).

Segundo o método de condicionamento clássico, o objeto é o estímulo não condicionado e a atitude favorável em relação ao objeto seria a resposta nãocondicionada. Por meio da repetição da satisfação que o objeto possa trazer ao indivíduo, a atitude favorável em relação a ele será manifestada sempre que o indivíduo entrar em contato com o objeto. Para Sheth et al (2001), esse método de aprendizado explica a criação, pelo indivíduo, de novas associações (crenças e sentimentos) entre objeto da atitude e fatores que influenciam para que a atitude seja ou não favorável em relação a este.

O método do condicionamento instrumental, por sua vez, assume que o indivíduo aprende a responder de determinada maneira por ela ser compensatória, sendo o objeto da atitude a própria recompensa para a atitude favorável. Da mesma maneira, a moldagem pode influenciar a formação de atitudes, já que a atitude favorável pode surgir na medida em que os indivíduos observam outros indivíduos em relação ao mesmo objeto de atitude.

Finalmente, o método cognitivo de aprendizagem influi diretamente nas crenças dos indivíduos em relação aos objetos. As crenças (ou componente cognitivo da atitude) seriam, assim, o principal fator para formação de uma atitude em relação a um objeto (DONEGÁ, 2004, p. 24).

As teorias de atribuição, no contexto da formação e moldagem de atitudes, explicam que o indivíduo atribuirá causas que expliquem uma possível incongruência entre sua atitude inicial em relação ao objeto e a seu comportamento final em relação ao objeto, de forma a criar uma nova atitude. Assim, a atitude será formada muito mais em função do comportamento desempenhado em relação ao objeto, do que em função do próprio objeto.

Essa atitude serve para que o indivíduo diminua qualquer desconforto causado pela incongruência entre atitude inicial e o comportamento desempenhado. Solomon (2002, p. 194) afirma que a teoria da atribuição descreve a formação e mudança de atitude como consequência das especulações das pessoas, tanto quanto o próprio comportamento (autopercepção) e as próprias expectativas. 
Já as teorias da consistência cognitiva garantem que as atitudes não são formadas no vácuo e que os indivíduos procuram harmonizar seus pensamentos, sentimentos e comportamentos, sendo motivados a manter uma coerência entre esses elementos.

Sobre essa coerência, Shiffman e Kanuk (2000, p. 171) afirmam que "[...] se necessário, os consumidores mudarão seus pensamentos, sentimentos ou comportamentos para torná-los coerentes com suas outras experiências". E que "um determinante importante da maneira como o objeto de atitude será avaliado é como ele se adapta a outras atitudes relacionadas já sustentadas pelo consumidor".

Sheth et al (2001) complementam:

"[...] as várias cognições que as pessoas mantêm devem ser consistentes umas com as outras. A inconsistência entre ideias causa tensões ou moções, que as pessoas são levadas a reduzir tornando consistentes as cognições sem consistência. As pessoas fazem isso mudando uma das cognições, para torná-la coerente com uma outra".

\subsubsection{Modelos de formação das atitudes}

Alguns modelos foram criados para se tentar entender a relação entre atitudes e comportamento dos consumidores.

A. Modelo tricomponente da atitude

O modelo de três componentes apresenta a atitude como formada por três dimensões principais: a cognitiva (conhecimento e percepções do indivíduo, advindos da experiência direta com o objeto da atitude e informações correlatas vindas de várias fontes), chamada por alguns autores de crença; a afetiva (formada pelas emoções e sentimentos do indivíduo), denominada sentimento; e a conativa (probabilidade ou tendência de que um indivíduo irá realizar uma ação ou comportar-se de uma maneira peculiar em relação a um objeto), chamada de intenção comportamental. 
Para Solomon (2002, p. 267), “todos os três componentes de uma atitude são importantes, mas sua importância relativa variará de acordo com o nível de motivação de um consumidor com relação ao objeto de atitude".

Para explicar o efeito de cada um dos três componentes na formação da atitude, e como se relacionam entre si, utiliza-se a hierarquia das atitudes, que, de acordo com Sheth et al (2001, p. 370), referem-se à "sequência em que os três componentes ocorrem".

Engel et al. (1995, p. 362) afirmam que atitudes são o que as pessoas gostam ou não gostam, ou "simplesmente uma avaliação geral"3, e que elas representam uma parte importante na determinação da posição do produto entre os consumidores. Ao discorrer sobre o que forma as atitudes, os autores comparam duas visões sobre seus componentes: a que chamam de visão tradicional, que afirma que as atitudes são compostas de componentes cognitivos (crenças), componentes afetivos (sentimentos) e componentes conativos (intenção comportamental), e a visão contemporânea da relação entre crenças, sentimentos, atitude, intenção comportamental e comportamento.

Nessa visão, as atitudes são influenciadas pelas crenças e também pelos sentimentos e, dependendo do produto que se esteja estudando, um dos dois fatores poderá ter maior influência, ou mesmo os dois produtos ao mesmo tempo. Os autores afirmam ainda que é ela (atitude) quem forma a intenção comportamental, que dará origem ao comportamento (ENGEL et al, 1995, p. 365).

A Figura 2 traz uma demonstração do modelo.

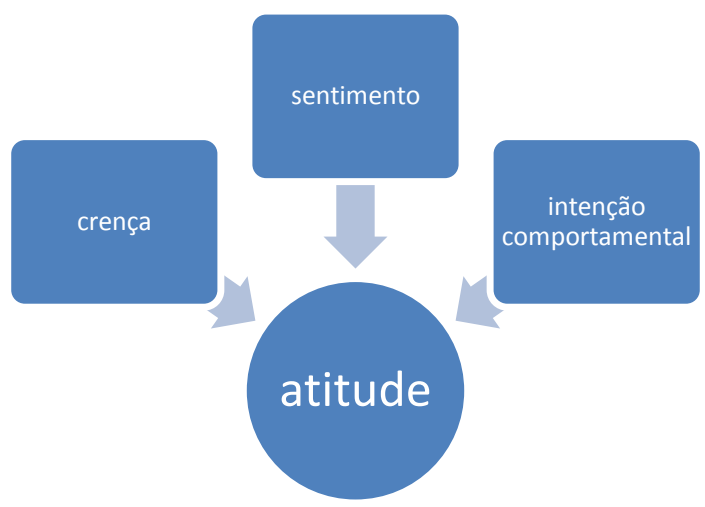

\footnotetext{
3 "simply an overall evaluation".
} 
Figura 2 - A visão tradicional tricomponente da atitude FONTE: Engel et al, 1995, p. 364.

B. Modelo de múltiplos atributos

Já a visão contemporânea relaciona a atitude mais com a intenção comportamental do que com o comportamento propriamente dito. Percebe-se que se mantém a importância em avaliar as atitudes, já que, mesmo que estas não influenciem o comportamento de forma direta, o farão indiretamente. $\mathrm{O}$ modelo está representado na Figura 3. 


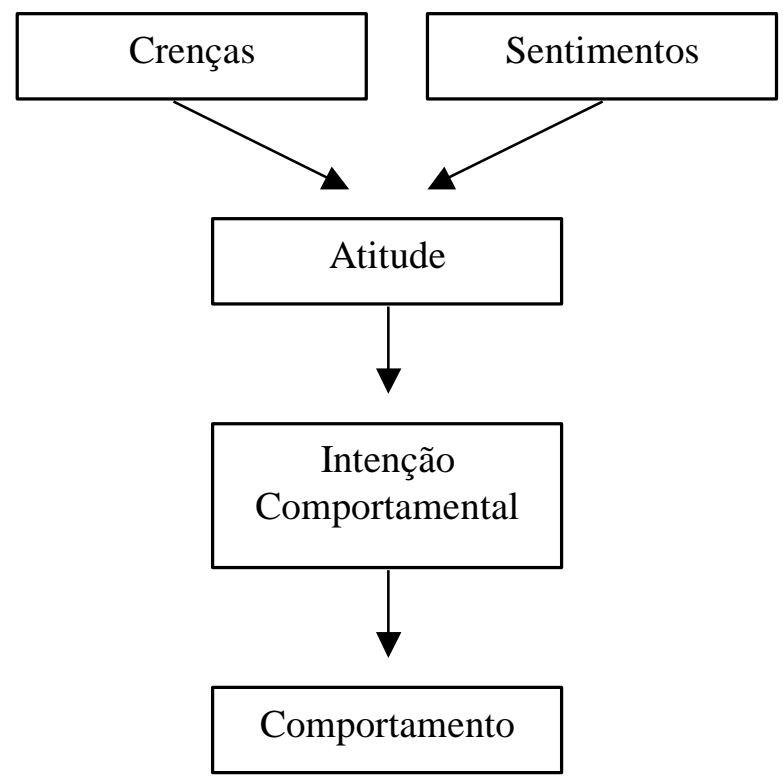

Figura 3 - Uma visão contemporânea da relação entre crenças, sentimentos, atitudes, intenção comportamental e comportamento

FONTE: Adaptado pela autora, com base em Engel et al, 1995, p. 365.

De acordo com o modelo, pode-se inferir que, uma vez que as atitudes podem influenciar as intenções, quanto mais favoráveis forem as atitudes em relação a determinado objeto ou produto que se esteja analisando, mais favoráveis serão as intenções quanto ao comportamento em relação a esse objeto ou produto.

Conforme observa Donegá (2004, p. 33), esse modelo também separa os componentes cognitivos, afetivos e conativos, relacionando apenas os dois primeiros na formação das atitudes. Nota-se que, apesar das diferenças entre os modelos apresentados até o momento, a identificação do componente cognitivo (intenção comportamental) é comum entre os modelos de formação das atitudes. De fato, Fishbein e Middlestadt (1995, apud AJZEN, 2001) afirmam que o componente cognitivo ainda é o principal elemento na formação das atitudes.

Assim, a maior mudança se dá no sentido de que, antes formadora da atitude, a intenção comportamental passa a ser formada por ela.

Relacionando atitudes, intenções e comportamento, foram desenvolvidas outras teorias com a intenção de melhor definir e prever o comportamento de compra do consumidor, e que têm sido largamente utilizadas, como a Teoria da Ação Racional (TRA - Theory of Reasoned Action) e a 
Teoria do Comportamento Planejado (TPB - Theory of Planned Behavior). Ambas serão estudadas com maior profundidade na próxima seção.

\subsection{A Teoria da Ação Racional e a Teoria do Comportamento Planejado}

Segundo Hoppe (2010, p. 25), o modelo proposto por Rosenberg e Hovland (1960) foi o primeiro a considerar as atitudes "como respostas afetivas, cognitivas e comportamentais frente a um objeto".

Esse modelo foi a inspiração para o desenvolvimento da Teoria da Ação Racional (Theory of Reasoned Action - TRA). Desenvolvida pelos professores do Departamento de Psicologia da Universidade de Massachussets, em 1967, essa teoria foi revisada e expandida nos anos 1970. Nos anos 1980, foi usada para estudar o comportamento humano, sugerindo que o comportamento é determinado pela intenção em desempenhá-lo, e que essa intenção é função de sua atitude frente ao comportamento e às normas subjetivas.

Ajzen e Fishbein (1980) afirmam que as crenças individuais que os consumidores têm sobre si próprios e sobre o mundo em que vivem são determinantes das normas subjetivas e das atitudes dos indivíduos, e que é necessário compreendê-los para entender o comportamento.

Quanto mais o comportamento se torna dependente de fatores externos, ou seja, fora do controle da pessoa (como a falta de um produto que queria adquirir, ou a quebra imprevista do veículo que transportava o produto e seu consequente atraso), menos o comportamento está sob controle voluntário. "A presença desses fatores incontroláveis pode assim interferir na habilidade da pessoa em fazer o que ele ou ela queria fazer" (ENGEL et al, 1995, p. 389). ${ }^{4}$

Para Shiffman e Kanuk (2000, p. 174), o modelo "representa uma integração completa dos componentes da atitude em forma de uma estrutura planejada para gerar tanto melhores explicações quanto melhores previsões de comportamento".

Sheth et al (2001, p. 387) complementam: "A vantagem do modelo [...] é que ele considera pressões sociais normativas e também as crenças internas sobre as consequências do comportamento".

\footnotetext{
4 "The presence of these uncontrollable factors can therefore interfere with the person's ability to do what he or she intended to do."
} 
Barcellos (2007, p. 33) cita Brown (1999) como um crítico da TRA, o qual expõe algumas de suas limitações, como “(1) a menor validade de aplicação do modelo em indivíduos que têm pouco controle sobre suas atitudes e comportamentos, seja por fatores internos (habilidades, stress; conhecimento) ou por fatores externos (fatores ambientais e situacionais) e (2) a inferência de que a intenção de comportamento é ilimitada”.

A Teoria do Comportamento Planejado (Theory of Planned Behavior - TPB) é uma extensão da TRA. Criada com a intenção de diminuir a primeira limitação, inclui no estudo a variável controle comportamental percebido. Segundo essa teoria, trata-se de uma variável que influencia tanto a intenção quanto o comportamento de compra e espera-se que a importância relativa da atitude, da norma subjetiva e do controle comportamental percebido na predição da intenção varie de acordo com os diferentes comportamentos e situações (AJZEN; FISHBEIN, 1980).

A TPB foi desenvolvida para tentar completar algumas falhas de adequação encontradas pelos autores durante as pesquisas usando a TRA. A única diferença entre as duas teorias é a inclusão do controle comportamental, percebido como um determinante adicional das intenções e comportamentos. No desenvolvimento da TRA, assumia-se que as pessoas têm controle da vontade sobre o comportamento de seu interesse (e que elas imaginam que são capazes de executar o comportamento se assim o desejarem). Sob essas condições, o controle comportamental percebido torna-se irrelevante, e a TPB se reduz à TRA (AJZEN, 2001).

Os psicólogos viam a atitude como um processo mental individual que determina as respostas reais e potenciais de uma pessoa, e assim tomavam a atitude como uma previsão para o comportamento. A TRA vê as intenções comportamentais mais que as atitudes, como os melhores preditores do comportamento. A TPB coloca o controle que uma pessoa tem ou imagina ter sobre seu comportamento como algo que o influencia e afirma que o comportamento intencional (behavioral intention) é influenciado pela atitude, pela norma subjetiva e pelo controle comportamental percebido.

O controle comportamental percebido refere-se às percepções do indivíduo quanto a suas habilidades para desempenhar um dado comportamento. Ajzen (2001) acrescenta ainda o controle comportamental atual, que se refere a como um indivíduo possui as habilidades, recursos e outros pré-requisitos necessários para desempenhar um dado comportamento. Logo, se o indivíduo percebe (ou acredita) que não possui um conjunto de habilidades ou recursos para desempenhar um determinado comportamento, suas intenções irão enfraquecer. Da mesma forma 
que na $T R A$, as atitudes favoráveis em relação ao comportamento não necessariamente irão prevê-lo.

Assim, de acordo com esse modelo, o comportamento não depende apenas de uma intenção favorável, mas também de um nível suficiente de controle sobre o comportamento. Esse nível é chamado de controle volitivo (DONEGÁ, 2004, p. 38).

Assim, são influenciadores do comportamento:

- $\quad$ atitude - é o grau com o qual a pessoa tem uma avaliação favorável ou desfavorável sobre o comportamento em questão;

- norma subjetiva - trata-se da influência da pressão social percebida pelo indivíduo para realizar ou não determinado comportamento;

- controle comportamental percebido - é a crença do indivíduo sobre quão fácil ou difícil será realizar ou não determinado comportamento.

A Figura 4 tenta facilitar a visualização desse processo:

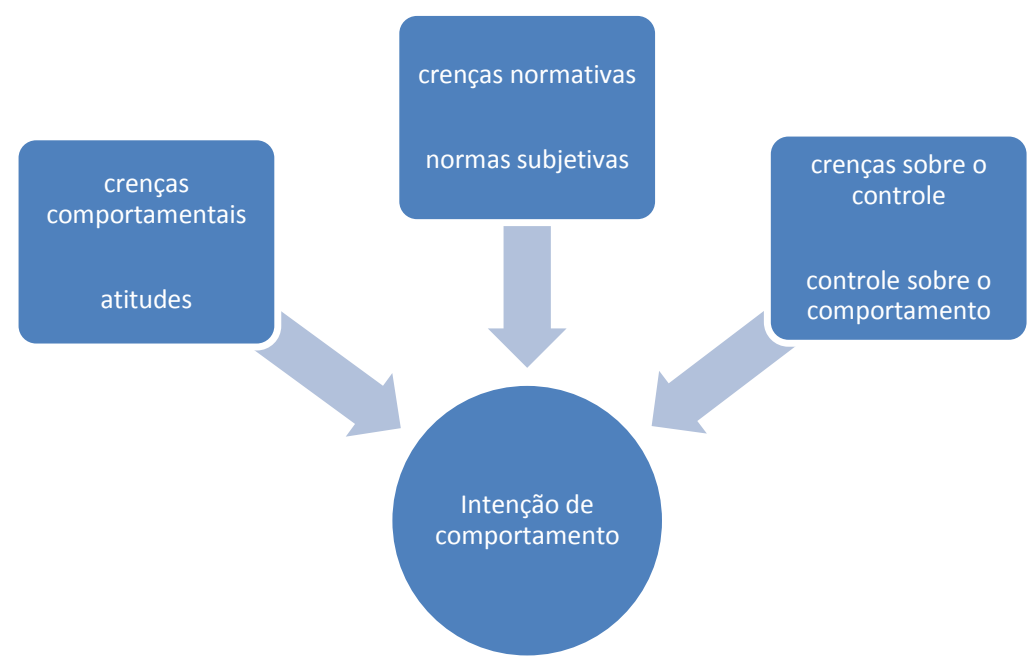

Figura 4 - Fatores que determinam a intenção comportamental

De acordo com Ajzen (2001, p. 43), vários estudos preocupados com a previsão do comportamento do consumidor compararam o poder preditivo da TPB com o de outros modelos, no entanto não conseguiram resultados muito melhores, ou tiveram resultados piores que essa 
teoria. Segundo Barcellos (2007, p. 34), o uso da TPB como base teórica para estudos em diversas áreas tem sido crescente, provavelmente por sua lógica simples e objetiva. A TPB tem sido utilizada inclusive em estudos fora da área de marketing (CORNÉLIO et al, 2009). Scholderer et al (2006) enfatizam a importância do hábito no consumo, o que comprovaram por meio de uma pesquisa realizada dentro do projeto SEAFOODplus, no qual incluíram o hábito como variável exógena, utilizando especificações da Teoria Estendida do Comportamento Planejado. Os resultados indicaram que o hábito prevê a atitude, a norma subjetiva e o controle percebido muito mais do que estes poderiam prever a intenção e o comportamento, refletindo aparentemente diferentes facetas da satisfação com o resultado de episódios passados do comportamento. Apesar de não existir uma resposta geral para a questão de se fatores habituais ou deliberativos são mais importantes no comportamento do consumo de alimentos, os hábitos parecem dominar o comportamento com relação ao consumo de frutos do mar. Pesquisas anteriores realizadas fora do contexto de alimentos confirmam que fatores habituais tendem a dominar, especialmente quando o comportamento buscado é realizado frequentemente e em um contexto estável; ao passo que fatores deliberativos tendem a dominar em situações em que o comportamento buscado é realizado raramente e em contextos instáveis.

Visando ao conhecimento sobre o que vem sendo feito neste sentido, e dado que o objeto de aplicação desta tese é a carne suína, montou-se o Quadro 1, que traz alguns estudos sobre o comportamento do consumidor de carnes (todos os tipos de carnes, para que a base fosse ampliada, uma vez que são bastante escassos os estudos aplicados desta teoria utilizando somente a carne suína), utilizando a $T P B$. 
Quadro 1 - Estudos sobre o comportamento do consumidor de carnes utilizando a TPB

\begin{tabular}{|c|c|c|}
\hline Autor(es)/Ano/Publicação & Objetivos/Método & Principais resultados \\
\hline $\begin{array}{l}\text { Povey et al (2001), } \\
\text { Appetite. }\end{array}$ & $\begin{array}{l}\text { Estudo investigou as diferenças entre as } \\
\text { atitudes e crenças de quatro grupos } \\
\text { (carnívoros, pessoas que evitam comer } \\
\text { carne, vegetarianos e vegetarianos } \\
\text { rígidos) e a maneira pela qual as atitudes } \\
\text { influenciaram as intenções em seguir } \\
\text { cada uma das dietas. Além disso, foi } \\
\text { investigado o papel da ambivalência de } \\
\text { atitude como variável moderadora. } \\
\text { Obtiveram-se questionários completos } \\
\text { de } 111 \text { respondentes ( } 25 \text { carnívoros, } 26 \\
\text { pessoas que evitam comer carne, } 34 \\
\text { vegetarianos e } 26 \text { vegetarianos rígidos. }\end{array}$ & $\begin{array}{l}\text { Em geral confirmaram-se as previsões de } \\
\text { que os respondentes apresentam mais } \\
\text { atitudes e crenças positivas em favor das } \\
\text { próprias dietas, e mais atitudes e crenças } \\
\text { negativas em relação à dieta mais } \\
\text { diferente da sua. Análises de regressão } \\
\text { mostraram que, como previsto pela TPB, } \\
\text { atitudes, norma subjetiva e controle } \\
\text { comportamental foram preditores } \\
\text { significantes da intenção em seguir cada } \\
\text { dieta (a não ser a dieta vegetariana, em } \\
\text { que a norma subjetiva foi não } \\
\text { significante). Os resultados não apenas } \\
\text { mostraram a extensão em que tais dietas } \\
\text { alternativas são um foco interessante para } \\
\text { a pesquisa psicológica, mas também } \\
\text { deram maior suporte ao argumento de que } \\
\text { a ambivalência é uma influência } \\
\text { importante na força da atitude. }\end{array}$ \\
\hline $\begin{array}{l}\text { McCarthy et al (2003), } \\
\text { Meat Science. }\end{array}$ & $\begin{array}{l}\text { Estudo realizado na Irlanda com o } \\
\text { objetivo de verificar as causas do } \\
\text { declínio do consumo de carne naquele } \\
\text { país. }\end{array}$ & $\begin{array}{l}\text { Fatores como meio ambiente, ética e bem- } \\
\text { estar animal foram identificados como as } \\
\text { principais causas da diminuição do } \\
\text { consumo de carne vermelha na Irlanda e } \\
\text { em toda a Europa. Dos entrevistados, } 93 \% \\
\text { consomem carne, } 47 \% \text { frequentemente, } \\
7 \% \text { muito frequentemente, } 41 \% \\
\text { quinzenalmente ou menos, } 5 \% \text { uma vez } \\
\text { por mês ou menos. }\end{array}$ \\
\hline $\begin{array}{l}\text { Verbeke e Vackier (2004), } \\
\text { Meat Science. }\end{array}$ & $\begin{array}{l}\text { O primeiro objetivo desta pesquisa é } \\
\text { investigar o comportamento do } \\
\text { consumidor em relação ao peixe na } \\
\text { Bélgica, usando a TPB como modelo } \\
\text { conceitual. O segundo objetivo é } \\
\text { examinar a influência das características } \\
\text { pessoais ou dos determinantes } \\
\text { individuais nas intenções, frequência de } \\
\text { consumo de peixe e seus antecedentes na } \\
T P B \text {. }\end{array}$ & $\begin{array}{l}\text { A } T P B \text { mostrou ser um modelo útil para o } \\
\text { entendimento dos determinantes do } \\
\text { consumo de peixe. Em geral, a atitude em } \\
\text { relação ao consumo de peixe, a norma } \\
\text { subjetiva e o controle comportamental } \\
\text { percebido têm influência } \\
\text { significantemente positiva na intenção de } \\
\text { comer peixe, enquanto a intenção junto } \\
\text { com o controle comportamental percebido } \\
\text { são dois determinantes significantes da } \\
\text { frequência de consumo. }\end{array}$ \\
\hline $\begin{array}{l}\text { Berndsen e Pligt (2004), } \\
\text { Appetite. }\end{array}$ & $\begin{array}{l}\text { O objetivo do estudo foi investigar se as } \\
\text { diferenças de ambivalência entre pessoas } \\
\text { que comem carne afetam suas atitudes } \\
\text { em relação ao consumo de carne, à }\end{array}$ & $\begin{array}{l}\text { Os resultados mostraram que os } \\
\text { consumidores de carne mais ambivalentes } \\
\text { tinham uma atitude menos positiva na } \\
\text { direção da carne quando comparados a }\end{array}$ \\
\hline
\end{tabular}




\begin{tabular}{|c|c|c|}
\hline & $\begin{array}{l}\text { estrutura de crença que baseia essas } \\
\text { atitudes e às intenções de reduzir o } \\
\text { consumo no futuro. }\end{array}$ & $\begin{array}{l}\text { consumidores de carne menos } \\
\text { ambivalentes. Além disso, a estrutura de } \\
\text { crença dos dois grupos é diferente: } \\
\text { pessoas mais ambivalentes associavam o } \\
\text { consumo de carne a sentimentos } \\
\text { levemente negativos, preocupações } \\
\text { moralmente inaceitáveis e a riscos para } \\
\text { sua saúde e o meio ambiente. }\end{array}$ \\
\hline $\begin{array}{l}\text { Mahon et al (2006), Food } \\
\text { Quality and Preference. }\end{array}$ & $\begin{array}{l}\text { Com o objetivo de analisar a eficácia da } \\
T P B \text { como preditor do consumo de } \\
\text { refeições prontas e para viagem, } \\
\text { estabelecer os fatores salientes e } \\
\text { normativos associados a esses alimentos } \\
\text { e demonstrar a aplicação do método para } \\
\text { desenvolver estratégias de marketing, } \\
\text { uma amostra nacionalmente } \\
\text { representativa de } 1.000 \text { respondentes } \\
\text { participou das entrevistas, realizadas em } \\
73 \text { pontos Grã-Bretanha, sendo feito o } \\
\text { mesmo número de entrevistas em cada } \\
\text { ponto. As entrevistas foram realizadas na } \\
\text { residência do respondente, tendo sido } \\
\text { solicitado que o principal responsável } \\
\text { por comprar alimentos e cozinhar } \\
\text { respondesse o questionário. Definiram- } \\
\text { se cotas de idade e colocação } \\
\text { profissional e dava-se um voucher de } \\
£ \$ 10,00 \text { como incentivo. }\end{array}$ & $\begin{array}{l}\text { Descobriu-se que para ambos os produtos } \\
\text { as atitudes eram o melhor preditor da } \\
\text { intenção comportamental. A norma } \\
\text { subjetiva foi importante para refeições } \\
\text { prontas, mas não para refeições para } \\
\text { viagem, enquanto o controle percebido } \\
\text { não foi um bom preditor para nenhum dos } \\
\text { alimentos. Uma variável adicional, o } \\
\text { hábito, foi incluída no estudo. Isso } \\
\text { aumentou o poder preditivo, mas reduziu } \\
\text { a influência das atitudes. Para ambos os } \\
\text { produtos, a intenção comportamental foi o } \\
\text { melhor preditor do comportamento para } \\
\text { um modelo que inclui intenção } \\
\text { comportamental, controle comportamental } \\
\text { percebido e hábito. }\end{array}$ \\
\hline $\begin{array}{l}\text { Fila e Smith (2006), } \\
\text { International Journal of } \\
\text { Behavioral Nutrition and } \\
\text { Physical Activity. }\end{array}$ & $\begin{array}{l}\text { Este artigo investiga a eficácia da } T P B \\
\text { para prever o comportamento } \\
\text { alimentação saudável em um grupo de } \\
\text { jovens nativos norte-americanos } \\
\text { urbanos. Realizaram-se } 139 \text { entrevistas } \\
\text { autoadministradas com garotos e garotas } \\
\text { de } 9 \text { a } 18 \text { anos para avaliar o } \\
\text { comportamento de alimentação, usando } \\
\text { os construtos da } T P B \text { (intenção, atitude, } \\
\text { norma subjetiva, barreiras, autoeficácia e } \\
\text { controle comportamental percebido). }\end{array}$ & $\begin{array}{l}\text { Não se encontrou associação entre } \\
\text { intenção e comportamento de alimentação } \\
\text { saudável. No entanto, o comportamento } \\
\text { de alimentação saudável independente foi } \\
\text { correlacionado com barreiras }(0,46) \text {, } \\
\text { atitude }(0,44) \text {, controle comportamental } \\
\text { percebido }(0,35) \text { e norma subjetiva }(0,34) \text {. } \\
\text { As barreiras mais preditivas à alimentação } \\
\text { saudável incluíam disponibilidade e sabor } \\
\text { dos alimentos. A falta de associação entre } \\
\text { intenção e comportamento alimentar } \\
\text { saudável sugere que outros fatores que } \\
\text { não intenções podem direcionar o } \\
\text { comportamento alimentar saudável nos } \\
\text { jovens urbanos norte-americanos nativos. }\end{array}$ \\
\hline $\begin{array}{lll}\text { Barcellos } & \text { (2007), tese } \\
\text { UFRGS. } & \end{array}$ & $\begin{array}{l}\text { O objetivo principal desta tese foi testar } \\
\text { um modelo teórico que pudesse } \\
\text { relacionar os construtos atitude, norma }\end{array}$ & $\begin{array}{l}\text { Os resultados obtidos confirmaram a } \\
\text { relação existente, direta e estatisticamente } \\
\text { significante, entre os construtos atitude, }\end{array}$ \\
\hline
\end{tabular}




\begin{tabular}{|c|c|c|}
\hline & $\begin{array}{l}\text { subjetiva, hábito e intenção de } \\
\text { comportamento no consumo de carne } \\
\text { bovina. Também se propôs uma análise } \\
\text { do impacto das emoções antecipadas } \\
\text { (positivas e negativas), do grau de } \\
\text { envolvimento e de diferenças culturais } \\
\text { como variáveis moderadoras no modelo. } \\
\text { Buscou-se ainda contribuir com a TPB } \\
\text { em estudos sobre o consumo de } \\
\text { alimentos pela inclusão do construto } \\
\text { hábito como um regressor independente } \\
\text { no modelo e pela exclusão do construto } \\
\text { controle percebido de comportamento. }\end{array}$ & $\begin{array}{l}\text { hábito e norma subjetiva com o } \\
\text { comportamento de consumo de carne } \\
\text { bovina. No entanto, o papel mediador da } \\
\text { intenção de comportamento entre a atitude } \\
\text { e a norma subjetiva com o } \\
\text { comportamento, postulado pela TPB, não } \\
\text { foi confirmado. Uma relação direta do } \\
\text { hábito para atitude também foi um achado } \\
\text { teórico relevante. A inclusão de hábito } \\
\text { como uma extensão à TPB foi considerada } \\
\text { apropriada, pois ajudou a explicar o } \\
\text { comportamento de consumo de carne } \\
\text { bovina. Os consumidores de Porto Alegre } \\
\text { e da Austrália apresentaram a relação } \\
\text { entre atitude e comportamento mais } \\
\text { positiva e níveis de envolvimento mais } \\
\text { altos com carne bovina do que os } \\
\text { consumidores de São Paulo e Holanda. }\end{array}$ \\
\hline $\begin{array}{l}\text { Bonne et al (2007), British } \\
\text { Food Journal. }\end{array}$ & $\begin{array}{l}\text { O objetivo do trabalho foi investigar os } \\
\text { determinantes do consumo de carne } \\
\text { halal em uma população migrante } \\
\text { muçulmana, usando a TPB como quadro } \\
\text { conceitual. O papel da autoidentidade } \\
\text { como uma aculturação muçulmana e } \\
\text { dietética na cultura hospedeira é } \\
\text { explorado. Dados cross-seccionais foram } \\
\text { obtidos por meio de uma pesquisa com } \\
576 \text { muçulmanos vindos principalmente } \\
\text { do Norte da África e vivendo atualmente } \\
\text { na França. }\end{array}$ & $\begin{array}{l}\text { Uma atitude positiva pessoal na direção } \\
\text { do consumo de carne halal, a influência } \\
\text { dos pares e o controle percebido sobre o } \\
\text { consumo de carne halal previram a } \\
\text { intenção de comer carne halal entre os } \\
\text { muçulmanos. Limitações incluem o uso } \\
\text { de uma amostra por conveniência e o foco } \\
\text { em apenas duas características } \\
\text { relacionadas ao consumo de alimentos } \\
\text { religiosos, como a autoidentidade e a } \\
\text { aculturação dietética. }\end{array}$ \\
\hline $\begin{array}{l}\text { Cornélio et al (2009), } \\
\text { Revista Latino-Americana } \\
\text { de Enfermagem. }\end{array}$ & $\begin{array}{l}\text { Este estudo teve como objetivo } \\
\text { apresentar a análise da validade de } \\
\text { conteúdo e da confiabilidade de um } \\
\text { instrumento para estudo dos fatores } \\
\text { determinantes do consumo de sódio } \\
\text { entre hipertensos, baseado na extensão } \\
\text { da TPB. O instrumento foi submetido à } \\
\text { validade de conteúdo por três juízes e } \\
\text { pré-teste com cinco sujeitos. O } \\
\text { instrumento final, composto por três } \\
\text { comportamentos relacionados ao } \\
\text { consumo de sal e pelas variáveis } \\
\text { psicossociais correspondentes, foi } \\
\text { aplicado a } 32 \text { sujeitos para avaliação da } \\
\text { consistência interna e da estabilidade } \\
\text { temporal (intervalo de } 15 \text { dias). }\end{array}$ & $\begin{array}{l}\text { De maneira global, os dados apontaram } \\
\text { evidências de que as medidas das } \\
\text { variáveis psicossociais que formam a } \\
\text { intenção dos três comportamentos, bem } \\
\text { como a medida da própria intenção, são } \\
\text { confiáveis, segundo os critérios da } \\
\text { homogeneidade e da estabilidade. A } \\
\text { norma subjetiva, nos três } \\
\text { comportamentos, apresentou o mesmo } \\
\text { item como pouco relacionado ao escore } \\
\text { total. }\end{array}$ \\
\hline
\end{tabular}




\begin{tabular}{|c|c|c|}
\hline $\begin{array}{l}\text { Bonne et al (2009), } \\
\text { Journal of International } \\
\text { Food and Agribusiness } \\
\text { Marketing. }\end{array}$ & $\begin{array}{l}\text { O estudo investiga os determinantes do } \\
\text { consumo de carne halal em uma } \\
\text { população migrante muçulmana belga } \\
\text { usando a TPB como modelo conceitual, } \\
\text { com foco no papel da autoidentidade e } \\
\text { aculturação no país hospedeiro. Dados } \\
\text { cross-seccionais foram colhidos em uma } \\
\text { pesquisa com } 367 \text { muçulmanos } \\
\text { principalmente originários do norte da } \\
\text { África e vivendo na Bélgica. }\end{array}$ & $\begin{array}{l}\text { Descobriu-se que, em geral, uma atitude } \\
\text { positiva sobre a saúde em relação à carne } \\
\text { halal prevê a intenção de consumir essa } \\
\text { carne entre os muçulmanos. A falta de } \\
\text { medidas de segurança percebida ou a } \\
\text { crença fraca nos controles de segurança } \\
\text { parecem ser barreiras potenciais que } \\
\text { impedem consumidores muçulmanos de } \\
\text { comer carne halal. Muçulmanos pouco } \\
\text { aculturados baseiam-se fortemente em sua } \\
\text { atitude pessoal positiva em relação ao } \\
\text { status saudável da carne halal, enquanto } \\
\text { muçulmanos bastante aculturados } \\
\text { baseiam-se na atitude saudável, atitudes } \\
\text { em relação ao bem-estar animal e } \\
\text { segurança quando pretendem comer carne } \\
\text { halal. }\end{array}$ \\
\hline
\end{tabular}

\subsection{O Food Related Lifestyle (FRL)}

A fim de investigar melhor os hábitos e o estilo de vida dos consumidores de carne suína no Brasil, este trabalho utilizou o Food Related Lifestyle (FRL), que une o estudo do estilo de vida com a alimentação.

O Food Related Lifestyle (FRL) é um instrumento de pesquisa desenvolvido no início dos anos 1990, com base em uma conceitualização de estilo de vida da teoria do meio e fim (BRUNSO et $a l, 2004)$. Nela, o estilo de vida é visto como um sistema de estruturas cognitivas que se situa entre valores e categorias cognitivas abstratas de um lado, e categorias cognitivas abstratas específicas de percepções e comportamentos de produto de outro lado. O estilo de vida é visto como um construto específico que mostra como as pessoas usam certos bens (neste caso, comida) a fim de atingir valores básicos.

No topo da hierarquia cognitiva, os valores pessoais são definidos como categorias cognitivas agregadas abstratas e trans-situacionais. No nível inferior, as percepções de produto são definidas como entradas de situações específicas em um processo de categorização.

A premissa teórica reside no que motiva e direciona o comportamento do consumidor e o que distingue estilo de vida de valores e comportamento. O estilo de vida é visto como um construto 
mental (categorias cognitivas, papéis e suas associações) que explica o comportamento real, não como o próprio comportamento (específico para aquisições de alimentos, aqui) (BRUNSO; GRUNERT, 1998).

O instrumento FRL (BRUNSO; GRUNERT, 1995) consiste em um conjunto de 23 fatores, cada um pertencente a uma de cinco dimensões inter-relacionadas (as três primeiras medindo diferenças individuais no uso habitual de papéis e habilidades), cobrindo as seguintes áreas:

1. maneiras de comprar - onde e como as pessoas compram alimentos, e também se a decisão de comprar é feita por impulso ou se é a consequência de um planejamento deliberado, a influência de informação fornecida por rótulos, por especialistas em alimentos, rede de contatos sociais ou o próprio vendedor do alimento;

2. métodos de cozinhar - como os alimentos são transformados em refeições reais, o tempo gasto na preparação, se é uma tarefa da família, e se é planejada ou uma atividade criativa e espontânea;

3. situação de consumo - refere-se à companhia, local e momento do consumo do alimento;

4. aspectos de qualidade - referem-se a atributos de todos os alimentos como seus aspectos de saúde, frescor, sabor e o quanto o alimento é natural, estimando um esquema geral da importância dada aos atributos do produto;

5. motivos de compra falam sobre a expectativa dos consumidores sobre a refeição e o quão importantes são as normas sociais, hedonismo, tradição e senso de segurança. Mede as diferenças individuais sobre a importância dada a referências específicas de alimentos sobre valores sociais (BRUNSO; GRUNERT, 1998; SCHOLDERER et al, 2004).

Desde 1995 o instrumento FRL tem sido aplicado com sucesso a consumidores de diferentes culturas, incluindo ingleses, dinamarqueses, franceses, alemães, espanhóis, holandeses e croatas (por exemplo, GRUNERT et al, 1997; BRUNSO; GRUNERT, 1995; BREDAHL et al, 1996; BRUNSO; GRUNERT, 1998; KESIC; PIRI-RAJH, 2003; BRUNSO et al, 2004; HOEK et al, 2004). A intenção geral dessas comparações era produzir dados que permitissem um melhor entendimento dos consumidores de alimentos nesses países com respeito a como eles usam produtos alimentares para atingir valores em suas vidas (BRUNSO; GRUNERT, 2007). O FRL 
também foi aplicado com limitações em Cingapura e na Austrália (ASKEGAARD; BRUNSO, 1999; REID et al, 2001).

Estudo de Kehagia et al (2010) analisa a validade do instrumento fora das fronteiras europeias em países com padrões culturais claramente diferentes de acordo com Liang (2007). Tal investigação torna-se ainda mais crucial considerando o cenário de consumo e comércio de alimentos no mundo. Analisam-se dados de consumidores brasileiros e chineses porque, de acordo com Liang (2007), espera-se que esses dois países exibam diferenças culturais consideráveis. Estuda-se se empresas (mais especificamente empresas de alimentos) deveriam adaptar-se ou padronizar elementos do marketing mix em mercados emergentes.

\subsection{Satisfação}

Ainda sobre o comportamento do consumidor, importa saber se ele fica satisfeito ao consumir o produto que se esteja estudando. Assim, desenvolveu-se toda uma área sobre este assunto dentro do marketing, que será abordada com maior profundidade nesta seção. Vale observar que, por suas próprias características de alta variação em relação a diferentes momentos de tempo, ou ainda pela influência de fatores instáveis como a expectativa que se tenha a respeito do produto ou serviço, trata-se de um conceito bastante questionado e alvo de críticas. Ainda assim, optamos por incluí-lo em nossa análise, pela farta teoria existente a respeito.

Segundo Kotler (2000), o profissional de marketing deve estar atento com o que acontece com o produto e especialmente com seu comprador após a compra. As ações e a maneira como o produto é utilizado pelo consumidor depois de comprado devem ser monitoradas, pois determinarão em grande parte a satisfação ou não do consumidor em relação ao produto adquirido (MOWEN, 2002; BOONE; KURTZ, 1998; CHIUSOLI et al, 2008).

É a satisfação que fará com que esse mesmo consumidor volte a consumir o produto, tornando-o fiel e constante (o que é a situação mais desejável para a empresa fabricante ou vendedora); fiel, porém esporádico (o que também é interessante); ou insatisfeito, que não voltará a consumir o produto e pode até realizar a contrapropaganda, ou seja, falar mal do produto para outras pessoas, influenciando-as de maneira negativa e atrapalhando o consumo do produto por outros potenciais consumidores. 
Segundo Bearden e Teel (1983), a satisfação é um precursor da compra repetida, da comunicação "boca-a-boca" positiva e da lealdade do consumidor. Para os consumidores, adquirir um produto que lhe ofereça a maior probabilidade de satisfazê-lo facilita o processo de decisão de compra e reduz o risco de não satisfação (RESANO et al, 2010).

A satisfação ou insatisfação depende em grande parte das expectativas a respeito do produto (BOONE; KURTZ, 1998, p. 186). Se estas são atingidas, o consumidor tende a ficar satisfeito com o produto. Caso contrário, pode ocorrer uma dissonância cognitiva, uma reação comum do consumidor quando se pergunta se a alternativa escolhida era de fato a melhor, ocorrendo o sentimento de remorso do comprador (CHURCHILL; PETER, 2000). A maneira de reduzir a dissonância e confirmar o acerto da decisão seria buscar mais informações positivas e evitar informações negativas sobre a alternativa escolhida (CZINKOTA, 2001; CHIUSOLI et al, 2008).

De acordo com Mowen (2002), o modelo do processo de pós-compra do consumidor engloba cinco estágios importantes:

1. uso ou consumo do produto;

2. satisfação ou insatisfação do consumidor;

3. comportamento de reclamação do consumidor;

4. disposição de produtos;

5. formação de fidelidade à marca.

No primeiro estágio, surge o processo de satisfação ou insatisfação. Se ocorrer a satisfação, forma-se a fidelidade à marca e a intenção de compra futura. Por outro lado, caso haja insatisfação, ocorrerá o comportamento de reclamação e a disposição do produto.

Depois do consumo do produto, geram-se os sentimentos no consumidor. Trata-se do estágio 2, de satisfação ou insatisfação. Ao atingir o estado de satisfação, o consumidor possui alguma atitude referente ao produto e serviço. De acordo com Engel et al (2000), satisfação é a avaliação pós-consumo em que uma alternativa escolhida pelo menos atende ou mesmo excede a expectativa.

Já Solomon (2002) afirma que a satisfação ou insatisfação do consumidor é determinada pelas sensações gerais, ou atitudes, em relação a um produto após comprá-lo. O processo de satisfação 
ou insatisfação do consumidor inicia-se com o uso de um produto, bem como o uso de marcas do mesmo tipo de produto. Esse comportamento de uso e as mensagens transmitidas pelas empresas e pessoas, fazem com que os consumidores criem expectativas sobre como deveria ser o desempenho da marca e do produto (MOWEN, 2002).

O comportamento de reclamação do consumidor é um termo que, segundo Mowen (2002), abrange todas as diferentes ações dos consumidores quando estão insatisfeitos com uma compra. Engel et al (2000) ressalvam que, quando o consumidor atinge o estado de insatisfação, pode agir de três formas diferentes: por meio de respostas verbais, diretamente com o vendedor; por meio de repostas particulares conhecidas como o "boca a boca" negativo; as respostas de terceiros, com a tramitação de processos legais.

Para Mowen (2002), embora o quarto estágio no processo de pós-compra - a disposição do produto - seja uma parte fundamental do processo de decisão do consumidor, este tem basicamente três opções como alternativas após usar o produto por algum período de tempo: mantê-lo; livrar-se dele permanentemente; livrar-se dele por algum tempo.

No último estágio, a fidelidade da marca está intimamente ligada à satisfação do consumidor e a seu comportamento de reclamação, e sua definição é o grau em que um consumidor mantém uma atitude positiva em relação à marca. Essa fidelidade é diretamente influenciada pela satisfação ou insatisfação acumulada ao longo do tempo (MOWEN, 2002; CHIUSOLI et al, 2008).

Apesar de toda esta importante teoria, o tema satisfação é bastante controverso, uma vez que pode-se afirmar que a satisfação não é algo concreto ou permanente. De fato, ela depemde de vários fatores ocasionais, e um consumidor pode ficar satisfeito ao consumir um produto em determinado local e em determinado momento, baseado em um certo conjunto de expectativas. No entanto, em um momento e em companhia diferente, aquelas expectativas podem ser alteradas, e a satisfação com o produto também podem mudar. Assim, ainda que a compra repetida ou a "fidelidade" do consumidor (outro termo altamente questionável) sejam de certa maneira indicadores da satisfação, trata-se de algo que não pode ser objetivamente afirmado: “o consumidor está satisfeito com o produto". 


\subsection{Estudo do Comportamento do Consumidor de Alimentos}

Ao estudar-se o consumo de alimentos, alguns fatores devem ser incluídos, diferentes de um estudo usual sobre o comportamento do consumidor. Quando aquestão é o ato de comer, existem riscos e sentimentos complexos difíceis de ser interpretados, entre os quais estão as motivações, influências, hábitos, preferências e riscos percebidos, que se somam e se misturam, tornando os momentos da compra do alimento, do ato de cozinhar, do consumo do alimento, atividades com diversos significados, além do objetivo básico de matar a fome (ZAMBERLAN et al, 2008, p. 23).

Steenkamp (1993) propõe uma abordagem ainda mais focada no comportamento do consumidor de alimentos, com três determinantes que denomina como os mais relevantes do comportamento do consumidor relacionados ao próprio indivíduo e aos fatores do ambiente. Segundo o autor, a alimentação exerce um papel central na vida dos consumidores, por ser fonte de experiências hedônicas e de nutrição, além de suas funções social e cultural. O autor contempla ainda a importância econômica considerável da alimentação, já que parcela significativa da renda domiciliar é alocada para a compra de alimentos.

No entanto, as pessoas possuem características diferentes, personalidades próprias e isso influencia a maneira como percebem os atributos nos produtos. Assim, no processo de tomada de decisão, o consumidor compara entre as diferentes alternativas de produtos capazes de satisfazer suas necessidades, seleciona, integra e avalia informações relacionadas aos produtos para ponderar entre as opções consideradas.

De acordo com Zeithaml (1988), informações sobre os produtos podem enquadrar-se em duas categorias gerais de atributos: os intrínsecos e os extrínsecos. Entre os elementos intrínsecos estariam os componentes físicos e as características funcionais como design, cor, resistência, sabor e matéria prima; já os extrínsecos associam-se ao produto, mas não fazem parte da composição física, como preço, propaganda, marca e disposição no ponto de venda.

Compreende-se o papel dos atributos do produto quando eles são integrados em um modelo de meios e fim que reúne as concepções de atributos, benefícios, custos e valor, e funcionam como meios utilizados nas avaliações do consumidor, amparando a decisão de compra (o fim). Ao avaliar um produto ou serviço, o consumidor normalmente considera os atributos intrínsecos, como a cor ou a textura, e os atributos extrínsecos, como a embalagem e o preço. 
No caso dos alimentos, esses atributos incluem ainda o cheiro, sabor, teor de gordura, maciez, entre vários outros, sendo muito importante saber quais dentre esses atributos são os que mais influenciam as decisões de compra dos consumidores (ZAMBERLAN et al, 2009; PENA et al, 2010).

Para o consumidor, cada atributo tem um significado e isso pode favorecer ou não a decisão de compra do produto. A presença de um ou mais atributos é o que garantirá a geração de benefícios e valores para o consumidor (TIBOLA et al, 2004).

Quando o produto é consumido, o consumidor avalia os atributos intrínsecos e extrínsecos e define os benefícios e custos percebidos. Dessa forma, eles são representados pelo comprador com grau mais alto de abstração do que os atributos. Os benefícios representam comportamentos e situações específicas. Há um custo monetário percebido equivalente à percepção do consumidor sobre o preço; além deste, a aquisição e o uso do produto geram outros custos de natureza não monetária, como tempo e esforço (SCHIFFMAN; KANUK, 2000; FARINA, 2002; LARÁN; ESPINOZA, 2004).

A combinação desses dois tipos afeta a percepção do indivíduo em relação ao nível de sacrifício vinculado à compra e ao consumo da oferta. Um mesmo atributo pode afetar benefícios e custos. No último estágio do esquema, os atributos, os benefícios e os custos, combinados, determinam o valor percebido, definido como a avaliação do consumidor sobre o nível de vantagem, excelência ou superioridade do produto (ZAMBERLAN et al, 2008).

Segundo Zeithaml (1988), os consumidores são normalmente mais influenciados pelos atributos intrínsecos (como cor ou textura) do que pelos extrínsecos (como a embalagem ou o preço) em determinadas situações: no momento do consumo; em situações de pré-compra, quando os atributos intrínsecos são atributos de procura mais do que atributos de experimentação; quando os atributos intrínsecos têm alto valor preditivo.

Por outro lado, os consumidores dependem mais de atributos extrínsecos do que de atributos intrínsecos: em situações iniciais de compra, quando as pistas intrínsecas não estão disponíveis (por exemplo, em serviços); quando a avaliação de pistas intrínsecas requer mais esforço e tempo do que o consumidor percebe como valor; quando a qualidade é difícil de avaliar (a não ser pela experiência ou se forem bens de crença).

Somados à influência das ocasiões de consumo e de compra e da disponibilidade de recursos, que normalmente exercem grande influência no comportamento do consumidor, o perigo de ver 
a família consumir um produto sobre o qual se tenha uma percepção de qualidade inferior aliado à sensação de estar desperdiçando dinheiro com a aquisição de um produto de qualidade inferior, conduz o consumidor à compra de marcas líderes, apesar de estas comumente terem preço mais alto que as concorrentes (SILVA, 2009; SERRALVO; IGNACIO, 2004). Na falta de um selo ou certificação dada por uma entidade isenta em que o consumidor tenha confiança, a marca pode ser uma opção para oferecer essa garantia (VIEIRA, 2009; SPERS, 2003; REZENDE, 2003).

Isto vai de encontro à afirmação de Seragini e Carvalho (2001, p. 129-130), de que há uma tendência mundial para redução da diferença entre produtos e marcas, e que, nesse contexto, os consumidores estariam deixando de preferir as marcas líderes para eleger outras que ofereçam melhores condições de compras. No caso de alimentos, isso dificilmente se confirma (SERRALVO; IGNACIO, 2004).

Faria et al (2006) afirmam que a percepção do consumidor sobre a qualidade de um produto baseia-se em suas características físicas e nas informações sobre ele e que, nesse sentido, o carimbo do Serviço de Inspeção Federal (SIF), aqui no Brasil, ofereceria uma garantia de qualidade para os produtos de origem animal, já que informa ao consumidor que aquele produto foi inspecionado por um órgão que atesta se ele seguro para o consumo.

A credibilidade da marca ou da certificação (confiança na fonte de informação) exerce grande impacto na aceitação do produto e tende a ser maior quando vem de algum órgão do governo (McCARTHY et al, 2003, p. 1073). Segundo os mesmos autores, a crença na comida saudável e na avaliação da carne como um produto saudável são de fundamental importância na atitude e, portanto, na intenção de consumir carne.

Para Moura et al (2009, p. 50), as embalagens e os rótulos dos produtos de carne suína devem destacar as informações consideradas importantes e que gerem segurança e garantias para os consumidores, e o posicionamento de marca deve enfatizar uma diferenciação valorizada pelos consumidores. Também “o processo de comunicação deve enfatizar esses atributos relacionados aos aspectos sensoriais e de segurança e garantia para os consumidores".

Aaker (1998) define marca como um nome específico e/ou um símbolo que tem o objetivo de identificar bens e serviços de um vendedor ou de um grupo de vendedores e diferenciar o nome desses bens e serviços dos concorrentes. Assim, ela define a origem do produto ou do serviço e consegue proteger tanto o consumidor quanto o fabricante de algum produto semelhante fabricado por um concorrente (FERREIRA; BARCELLOS, 2003, p. 4). 
Sob uma perspectiva de consumidor, marcas são importantes dicas de qualidade e tornam mais fácil inferir qualidade (GRUNERT, 2001). Sistemas de rastreabilidade, marcas e rótulos podem ajudar a reduzir a dependência do consumidor em fatores de crença. Apesar disto, para Bernués et al (2003), a marca tem pouca relevância para a maioria dos consumidores.

Já Tybout e Carpenter (2001) afirmam que as marcas têm valor para os clientes, na medida em que asseguram qualidade, simplificam as escolhas e ajudam os consumidores a conseguir a satisfação das necessidades básicas entre outros benefícios.

Segundo Aaker (1998), é importante definir o grau de satisfação ou de insatisfação dos consumidores com relação à marca porque o valor de marca (conjunto de ativos e passivos ligados a ela, seu nome e seu símbolo, que se somam ou se subtraem do valor proporcionado por um produto ou serviço para uma empresa ou para seus consumidores) passa a existir para o consumidor somente a partir do momento em que ele passa a perceber as vantagens e desvantagens de uma determinada marca em relação aos concorrentes. As marcas trazem benefícios também às empresas que as criam (FERREIRA; BARCELLOS, 2003, p. 4).

Assim, a marca deve estar associada a algum benefício que tenha diferentemente dos concorrentes e que seja relevante para o cliente, devendo sintetizar a promessa, o benefício oferecido pelos produtos e serviços da empresa (AAKER, 2000).

Produtos sem marca como a carne suína fresca tornam mais difícil para o consumidor formar expectativas quanto à qualidade. Rótulos ou marcas podem oferecer ao consumidor outras formas de garantir experiência e características de crença aos produtos alimentares (GRUNERT, 2002).

Em estudo realizado por Saab (1999) que investiga os atributos que o consumidor valoriza na carne bovina, foi "criado" um selo de garantia de qualidade para a carne, como forma de incluir na pesquisa tal atributo (garantia de qualidade). Na pesquisa inicial feita com especialistas, esse atributo foi considerado extremamente importante, constatando-se que não poderia deixar de ser considerado no estudo. Como não existia nenhum tipo de certificação ou marca que pudesse atestar a qualidade do produto, foi utilizado esse selo, que poderia hipoteticamente ser conferido ao produto por um açougue, frigorífico ou associação.

De acordo com McCarthy et al (2003, p. 1072), fatores como gosto, preferência, aparência e atributos sensoriais contribuem para o nível individual de 'prazer de comer' quando se refere ao consumo de carne. Este seria, para vários autores (GRUNERT, 1997; LISTER, 1996; 
ZAMBERLAN et al, 2008), o atributo mais importante para os consumidores ao consumir carne. Vários estudos apontaram o sabor como o principal fator de influência na escolha do consumo de alimentos em geral (GRUNERT et al, 2000; RICHARDSON et al, 1994; SHEPHERD, 1990; URALA; LAHTEENMAKI, 2003).

Estudo realizado na Irlanda por Mahon et al (2006), afirma que a crença na comida saudável e na avaliação da carne como um produto saudável são de fundamental importância na atitude e, portanto, na intenção de consumir carne, e que questões relativas a preço não são determinantes significativos da atitude. No entanto percepções positivas de saúde e sabor resultam em atitudes positivas com relação à carne. Assim, realçar os benefícios à saúde e concentrar em garantir uma experiência positiva de sabor podem aumentar a demanda. Os autores afirmam também a importância do conselho de especialistas (médicos e nutricionistas) como influenciadores do consumo.

Segundo resultados de estudo realizado por MacBean (1996), as preferências do consumidor em favor de conveniência e segurança (saúde) eram mais fortes com relação à carne que com relação a outros alimentos, o que vai ao encontro do que afirma Lister (1996), cujo estudo determinou que a carne é comida para ser saboreada e não por qualquer valor nutricional que possa ter.

Cassotti (2001) afirma que o consumo de alimentos não é definido por uma relação de custobenefício das escolhas e, sim, por experiências adquiridas do consumo passado e presente.

Sobre a qualidade do produto, Grunert (1995, p. 171) propõe a distinção entre três tipos de qualidade:

- qualidade orientada para o produto, que seria medida por meio das características físicas do produto, como porcentagem de gordura, tamanho muscular da carne, conteúdo de células no leite, entre outros. Por ser possível medir no próprio produto por métodos fisiológicos, pode também ser chamada qualidade objetiva;

- qualidade orientada para o processo, que diz respeito à medida na qual a qualidade do produto se mantém estável em níveis preestabelecidos, e também pode ser chamada de qualidade objetiva;

- qualidade orientada para o usuário, que é a percepção subjetiva de um usuário, que pode ser o usuário final ou um intermediário na cadeia produtiva, como um varejista. Por ser 
passível de ser medida apenas pelo usuário, e poder ser diferente para o mesmo produto entre diferentes usuários, pode ser chamada de qualidade subjetiva.

O Total Food Quality Management (TFQM) é uma teoria criada por Grunert (1997), que também tem sido largamente utilizada no estudo do comportamento do consumidor de alimentos. Nela, faz-se uma distinção entre avaliações antes e depois da compra. Dimensões de qualidade são categorizadas em características de busca, experiência e crença:

- características de busca (aparência da carne) - podem ser avaliadas antes da compra;

- características de experiência (sabor da carne) - somente podem ser avaliadas depois da compra;

- características de crença (características saudáveis da carne) - não podem ser avaliadas, mas dependem da confiança do consumidor na informação oferecida.

Assim, a fim de fazer uma escolha, o consumidor desenvolverá expectativas sobre qualidade, o que poderá ser confirmado ou não somente após o consumo, e mesmo aí há limitações no caso de características de crença, como quando se fala a respeito das qualidades saudáveis do produto. A distinção entre antes e após a compra forma, então, a base do TFQM (GRUNERT et al, 2004). Grunert (1997, p. 157) afirma ainda que o grau de satisfação obtido pelo consumo de um produto é frequentemente apenas levemente relacionado às informações disponíveis na situação de compra. Para produtos alimentícios, o sabor é tipicamente uma característica de experiência (a menos que seja possível a degustação do produto antes da compra), enquanto o teor de gordura de um pedaço de carne é uma característica de busca.

O autor segue afirmando que pode haver um terceiro grupo de características, chamadas de características de crenças, a respeito das quais o consumidor não pode ter certeza nem após o consumo. São essas as características mais sujeitas ao fator credibilidade do produto e da marca ou da empresa fabricante.

Além de tantas teorias, outra importante área que vem se desenvolvendo no estudo do comportamento do consumidor é o Neuromarketing, que busca desvendar essa grande incógnita que é a mente do consumidor a fim de tentar prever seu comportamento utilizando a ciência como base (CAMARGO, 2009). 
O Quadro 2 traz alguns estudos realizados no Brasil sobre o comportamento do consumidor de carnes, incluindo artigos publicados em periódicos, apresentados em Congressos, teses e dissertações.

Quadro 2 - Estudos sobre o comportamento do consumidor de carnes no Brasil

\begin{tabular}{|c|c|c|}
\hline Autor(es)/Ano/Publicação & Objetivos/Método & Principais resultados \\
\hline $\begin{array}{l}\text { Barcellos (2002), dissertação de } \\
\text { Mestrado da UFRGS. }\end{array}$ & $\begin{array}{l}\text { Estudo realizado com } 400 \\
\text { consumidores de carne bovina em } \\
\text { Porto Alegre (RS). }\end{array}$ & $\begin{array}{l}\text { Identificou o churrasco como uma } \\
\text { "ocasião especial de consumo" para } 68 \% \\
\text { dos entrevistados. Os respondentes } \\
\text { reconheceram que o processo de compra } \\
\text { desse produto é diferenciado e requer } \\
\text { conhecimentos especiais; o açougue foi } \\
\text { o canal de distribuição preferido para } \\
\text { adquirir a carne bovina para essa ocasião } \\
\text { de consumo }\end{array}$ \\
\hline $\begin{array}{l}\text { Brisola e Castro }(2005) \text {, } \\
\text { REGE/USP. }\end{array}$ & $\begin{array}{l}\text { Pesquisa realizada na cidade de } \\
\text { Brasília com consumidores de carne } \\
\text { bovina para avaliar suas preferências } \\
\text { em relação ao ponto de venda e ao } \\
\text { produto pesquisado. }\end{array}$ & $\begin{array}{l}\text { Observou-se uma preferência dos } \\
\text { consumidores entrevistados pelos } \\
\text { supermercados como ponto de compra. } \\
\text { A higiene do ambiente, a conservação } \\
\text { dos produtos e a atuação de uma } \\
\text { fiscalização sanitária superam o baixo } \\
\text { preço oferecido pelo ponto de compra, } \\
\text { como aspectos preferenciais. Em relação } \\
\text { ao produto, os consumidores apreciam } \\
\text { mais os aspectos visuais (cores da carne } \\
\text { e da gordura), a limpeza da peça e } \\
\text { aspectos relacionados ao sabor e maciez, } \\
\text { do que informações sobre o produto e } \\
\text { sua origem apresentadas na embalagem. }\end{array}$ \\
\hline $\begin{array}{l}\text { Montini (2005), Informações } \\
\text { Econômicas. }\end{array}$ & $\begin{array}{l}\text { O trabalho, que aborda a } \\
\text { possibilidade de mudanças no } \\
\text { consumo de carne bovina na região } \\
\text { de Londrina (PR), utilizou o método } \\
\text { do estudo experimental. A pesquisa } \\
\text { foi realizada no município de } \\
\text { Londrina, e a aplicação dos } \\
\text { questionários foi feita nos quatro } \\
\text { hipermercados da cidade. }\end{array}$ & $\begin{array}{l}\text { A coleta de dados nos estabelecimentos } \\
\text { escolhidos para o estudo experimental } \\
\text { mostrou que os consumidores estão } \\
\text { dispostos a pagar mais por um produto } \\
\text { que venha com embalagem e com } \\
\text { certificado de origem. Os resultados } \\
\text { apontaram a falta de informação e de } \\
\text { ações de marketing no mercado interno } \\
\text { pelos consumidores, não somente para } \\
\text { aumentar o consumo, mas também para } \\
\text { esclarecer dúvidas e explicar sobre as } \\
\text { novas formas de manejo e sobre o } \\
\text { sistema de embalagem dos produtos. }\end{array}$ \\
\hline $\begin{array}{llll}\text { Barcellos } e t & a l & (2005), \\
\text { Proceedings } & \text { of } & \text { the } & \text { IAMA }\end{array}$ & $\begin{array}{l}\text { O objetivo principal da pesquisa } \\
\text { inicial foi propor e testar um modelo }\end{array}$ & $\begin{array}{l}\text { Os } \quad \text { especialistas } \quad \text { reconheceram a } \\
\text { importância do papel do envolvimento e }\end{array}$ \\
\hline
\end{tabular}




\begin{tabular}{|c|c|c|}
\hline Conference. & $\begin{array}{l}\text { teórico que relaciona envolvimento e } \\
\text { emoção no consumo de carne bovina, } \\
\text { analisando a influência da cultura } \\
\text { entre os consumidores de diferentes } \\
\text { países. Analisaram-se as percepções } \\
\text { de } 20 \text { especialistas sobre o assunto, } \\
\text { como estágio inicial de uma tese, } \\
\text { com objetivo exploratório na primeira } \\
\text { fase, feito como uma pesquisa } \\
\text { qualitativa por meio de entrevistas } \\
\text { em profundidade com especialistas da } \\
\text { cadeia de carne bovina, a fim de } \\
\text { validar as variáveis descritas na } \\
\text { literatura como parte dos construtos. }\end{array}$ & $\begin{array}{l}\text { das emoções no consumo de carne } \\
\text { bovina e validaram o questionário que } \\
\text { será aplicado no próximo estágio da } \\
\text { pesquisa. Descobriu-se também que a } \\
\text { cultura tem um papel importante no } \\
\text { entendimento do comportamento do } \\
\text { consumidor e será mais explorada no } \\
\text { trabalho final. }\end{array}$ \\
\hline $\begin{array}{l}\text { Novaes et al (2006), Anais do } \\
\text { XLIV Congresso da Sober. }\end{array}$ & $\begin{array}{l}\text { Este artigo analisa a evolução da } \\
\text { frequência declarada de consumo de } \\
\text { carne bovina e de hortaliças no } \\
\text { Brasil. Para isso, utilizou-se o método } \\
\text { dedutivo de pesquisa e a pesquisa } \\
\text { documental e de campo (survey) } \\
\text { como métodos de procedimento. } \\
\text { Foram aplicados } 1545 \text { questionários } \\
\text { em quatro capitais brasileiras. }\end{array}$ & $\begin{array}{l}\text { Os resultados apontam para um maior } \\
\text { consumo de hortaliças à medida que } \\
\text { aumentam os capitais econômico e } \\
\text { cultural, este último medido, neste } \\
\text { trabalho, pelo nível de escolaridade da } \\
\text { população. Uma maior frequência de } \\
\text { consumo de carne bovina é declarada } \\
\text { por consumidores com renda familiar } \\
\text { entre } 8 \text { e } 10 \text { salários mínimos mensais, } \\
\text { no entanto com menor nível de } \\
\text { escolaridade. Foi observado que, quando } \\
\text { comparados indivíduos com o mesmo } \\
\text { nível de renda, os de maior grau de } \\
\text { escolaridade consomem menos carne } \\
\text { bovina e mais hortaliças. }\end{array}$ \\
\hline $\begin{array}{l}\text { Zamberlan et al (2008), } \\
\text { Enanpad. }\end{array}$ & $\begin{array}{l}\text { Estudo realizado no Rio Grande do } \\
\text { Sul com consumidores de carne. } \\
\text { Incluiu uma fase qualitativa, com } \\
\text { pesquisa bibliográfica e focus group } \\
\text { além de fase qualitativa com } \\
\text { aplicação de } 444 \text { questionários para } \\
\text { avaliar o comportamento de consumo } \\
\text { da amostra. }\end{array}$ & $\begin{array}{l}\text { Analisaram-se os fatores que afetam e } \\
\text { determinam o comportamento do } \\
\text { consumidor de carne, em especial a } \\
\text { cultura, indicando a necessidade de as } \\
\text { instituições da cadeia da carne } \\
\text { aprofundarem o conhecimento sobre as } \\
\text { mudanças provocadas principalmente } \\
\text { pela globalização nos hábitos } \\
\text { alimentares. }\end{array}$ \\
\hline $\begin{array}{lll}\text { Vendrame } & \text { et } & \text { al }(2008), 6^{\circ} \\
\text { Congresso de } & \text { Pós-Graduação, } \\
\text { Unimep. } & & \end{array}$ & $\begin{array}{l}\text { O artigo buscou caracterizar } \mathrm{o} \\
\text { comportamento do consumidor de } \\
\text { carnes no Brasil através de pesquisa } \\
\text { bibliográfica. }\end{array}$ & $\begin{array}{l}\text { Conclui-se que conhecer o consumidor é } \\
\text { necessário para que se obtenha sucesso } \\
\text { em qualquer negócio e se possam } \\
\text { formular estratégias para várias cadeias } \\
\text { produtivas, inclusive a da carne bovina. }\end{array}$ \\
\hline $\begin{array}{l}\text { Truocchio e Antonialli (2008), } \\
\text { Anais do XLVI Congresso da }\end{array}$ & $\begin{array}{l}\text { O objetivo da pesquisa foi identificar } \\
\text { os atributos considerados importantes }\end{array}$ & $\begin{array}{l}\text { Como conclusões da pesquisa, destaca- } \\
\text { se que os compradores de carne suína }\end{array}$ \\
\hline
\end{tabular}




\begin{tabular}{|c|c|c|}
\hline Sober. & $\begin{array}{l}\text { na decisão de compra dos } \\
\text { compradores de carne suína em Belo } \\
\text { Horizonte (MG). Realizou-se uma } \\
\text { pesquisa de natureza quantitativa } \\
\text { cujos dados foram coletados por meio } \\
\text { de um levantamento do tipo survey } \\
\text { aplicando-se um questionário } \\
\text { estruturado a uma amostra de } 399 \\
\text { compradores de carne suína em Belo } \\
\text { Horizonte-MG. }\end{array}$ & $\begin{array}{l}\text { estão mais exigentes quanto à aparência, } \\
\text { qualidade e segurança alimentar, mas } \\
\text { também querem mais benefícios } \\
\text { agregados ao produto como comodidade } \\
\text { e praticidade. Espera-se que os } \\
\text { resultados da presente pesquisa } \\
\text { contribuam para ampliar a compreensão } \\
\text { do estudo sobre o comportamento de } \\
\text { compra de carne suína, bem como } \\
\text { subsidiar as estratégias de marketing dos } \\
\text { agentes dessa cadeia produtiva. }\end{array}$ \\
\hline $\begin{array}{l}\text { Silva (2009), Informativo da } \\
\text { Cadeia da Carne Bovina do } \\
\text { Pantanal Mato-Grossense. }\end{array}$ & $\begin{array}{l}\text { O trabalho buscou a identificação dos } \\
\text { valores que influenciam o } \\
\text { comportamento do consumidor de } \\
\text { carnes e respectivos benefícios e } \\
\text { atributos de produtos de duas marcas } \\
\text { líderes }\end{array}$ & $\begin{array}{l}\text { Os motivadores de compra que } \\
\text { influenciam o comportamento do } \\
\text { consumidor frente às marcas líderes do } \\
\text { segmento de produtos alimentícios, } \\
\text { consistem em valores como a busca por } \\
\text { realização pessoal e social, por respeito } \\
\text { em seu papel como consumidores, assim } \\
\text { como pela necessidade de } \\
\text { entretenimento e lazer. }\end{array}$ \\
\hline $\begin{array}{l}\text { Moura et al (2009), Informe } \\
\text { GEPEC. }\end{array}$ & $\begin{array}{l}\text { O objetivo deste trabalho foi } \\
\text { identificar quais os principais } \\
\text { atributos valorizados pelos } \\
\text { consumidores de carne suína. A } \\
\text { pesquisa dividiu-se em duas etapas: } \\
\text { na primeira, foram realizadas } \\
\text { entrevistas em profundidade com } \\
\text { consumidores, cujos resultados foram } \\
\text { utilizados para a confecção do } \\
\text { questionário. Depois foi realizado um } \\
\text { pré-teste para possíveis correções e } \\
\text { cálculo da amostra. Obtiveram-se } 456 \\
\text { questionários válidos. }\end{array}$ & $\begin{array}{l}\text { Por meio da análise fatorial, foram } \\
\text { identificados quatro fatores: "garantias e } \\
\text { segurança", "comodidade e } \\
\text { versatilidade", "aspectos nutricionais e } \\
\text { de saúde" e "aspectos sensoriais", } \\
\text { formados pelos } 27 \text { aspectos da carne } \\
\text { suína que os consumidores valorizam. } \\
\text { Observou-se que os dez atributos } \\
\text { considerados mais importantes estão } \\
\text { contidos nos fatores "aspectos } \\
\text { sensoriais" e "garantias e segurança". } \\
\text { Ainda na análise de dados, a análise de } \\
\text { cluster indicou dois grupos, formados } \\
\text { entre homens e mulheres, sendo as } \\
\text { mulheres mais exigentes em relação à } \\
\text { qualidade do produto do que os homens. }\end{array}$ \\
\hline
\end{tabular}

O objetivo deste capítulo foi, desta maneira, apresentar de maneira sucinta um pouco do que tem sido feito sobre o comportamento do consumidor, a variedade de teorias que existem para tentar entendê-lo e explicá-lo, e a importância que o seu estudo tem na administração de empresas. No entanto, dentre tantas e tão importantes teorias a respeito do comportamento do consumidor, utilizar-se-á somente parte da base teórica exposta até aqui, e como base prática fará a análise 
dos dados obtidos em pesquisa realizada dentro de um projeto da Comunidade Europeia, no qual foi feita uma pesquisa com consumidores de carne suína no Brasil.

Tendo como base a Teoria do Comportamento do Consumidor, em especial a Teoria Cognitiva, descrita no item 2.3, que aborda o consumo de maneira mais integrada entre produto, consumidor e ambiente, e estuda a influência de fatores como percepção, motivação, aprendizagem, memória, atitudes, valores e personalidade, além do estilo de vida dos consumidores, buscou-se replicar parcialmente um importante e abrangente projeto internacional no setor de carne suína, o projeto Q-PorkChains, que será mais bem descrito no item 2.8, a seguir.

\subsection{O Projeto Q-PorkChains}

O nome completo do projeto Q-PorkChains é: “Improving the quality of pork and pork products for the consumer: development of innovative, integrated, and sustainable food production chains of high quality pork products matching consumer demands".

Com o objetivo principal de melhorar a qualidade dos suínos e dos produtos de suínos ao longo de toda a cadeia produtiva, adaptando-os à demanda do consumidor, o Projeto Integrado $Q$ PorkChains teve início em janeiro de 2007 e é basicamente custeado pela Comunidade Europeia sob o Programa Sixth Framework para Pesquisa, Desenvolvimento Tecnológico e Atividades de Demonstração. Assim, envolve 54 instituições, entre universidades, institutos de pesquisa, associações, centros de estudos e empresas privadas, e compreende seis áreas distintas e integradas, chamadas de módulos, cada um coordenado por uma universidade diferente, dependendo da especialidade:

1. Análise do Consumidor e do Mercado - coordenado pelo prof. Klaus Grunert, da Universidade de Aarhus, da Dinamarca;

2. Diversidade, Flexibilidade e Sustentabilidade em Sistemas de Produção a Nível da Fazenda - coordenado pelo INRA - Instituto Nacional Francês para Pesquisas Agrícolas, da França; 
3. Desenvolvimento de Produtos - Qualidade, Nutrição e Conveniência - coordenado pelo IRTA - Instituto de Pesquisa e Tecnologia de Alimentos e Agricultura, da Espanha;

4. Integração e Gerenciamento Sustentável da Cadeia Produtiva - coordenado pelo prof. Jacques Trienekens, da Universidade de Wageningen, na Holanda;

5. A Nova Biologia como Ferramenta para Controle da Carne Suína - coordenado pelo Instituto Dinamarquês de Ciências Agrícolas, da Dinamarca;

6. Síntese do conhecimento existente em Qualidade, Segurança e Bem-estar dos Suínos coordenado pelo ASGV - Instituto de Ciência e Saúde Animal, da Holanda.

Além desses, haverá três módulos verticais, responsáveis por:

A. Cadeias Piloto e de Demonstração e Redes de Pequenas e Médias Empresas coordenado pelo GIQS, da Alemanha;

B. Educação, Treinamento e Disseminação - coordenado pela Universidade Real Agrícola e Veterinária - Universidade de Copenhagen, da Dinamarca;

C. Administração Geral - coordenado pela Universidade de Copenhagen, da Dinamarca.

O objetivo geral do projeto está expresso no título: 'Melhorando a qualidade da carne suína e produtos à base de carne suína para o consumidor: desenvolvimento de cadeias produtivas alimentares inovadoras, integradas e sustentáveis de produtos de carne suína de alta qualidade atendendo às demandas do consumidor'.

O projeto pretende contribuir com este objetivo geral para atingir o objetivo estratégico: 'Desenvolvimento e teste de abordagens avançadas e multidisciplinares para identificação, caracterização, previsão e controle da qualidade da carne suína e produtos à base de carne suína em diferentes estágios da cadeia da carne suína em diversos sistemas de produção’.

Também, objetiva-se obter resultados que permitam ao setor produzir produtos de suínos de maneira sustentável e seguros com qualidade e aspectos nutricionais melhorados, mais convenientes de preparar e de acordo com as demandas do consumidor por diversidade. Isso será feito por meio de estudos e do desenvolvimento de aspectos do comportamento e preferências do consumidor da cadeia de suínos, sistemas de produção sustentável, desenvolvimento de produtos, 
integração na cadeia produtiva e desenvolvimento de novos métodos em diversos países, inclusive na China e no Brasil.

O Módulo I, do qual esta pesquisa é parte integrante, tem como objetivo geral entender a participação da cadeia de suínos na vida dos consumidores, por meio de um entendimento profundo da maneira como cidadãos se relacionam com a produção de suínos. Pretende-se estudar os problemas que o setor enfrentará nos próximos anos, incluindo a sugestão de políticas a serem adotadas para o setor e desafios de comunicação. Além disso, o projeto investiga as maneiras como a carne suína e produtos feitos à base de carne suína são percebidos, escolhidos, preparados e consumidos na Europa, e ainda na China e no Brasil, incluindo tendências, necessidades emergentes, e falhas do mercado. O módulo tem como objetivos específicos:

$>$ identificar e mapear atitudes de cidadãos e sistemas de valores relevantes à produção de suínos;

$>$ investigar as diversas maneiras como a carne suína é inserida no consumo;

$>$ segmentar o mercado baseando-se nas atitudes dos cidadãos e comportamento dos consumidores;

$>$ determinar perfis de consumidores com base em dados sociodemográficos e estilo de vida;

$>$ determinar a atratividade dos segmentos delineados.

Para atingir esses objetivos, foi realizada uma pesquisa em cinco países europeus selecionados (Grécia, Bélgica, Dinamarca, Polônia e Alemanha), além de China e Brasil, com uma amostra de 480 respondentes, fixa para todos os países.

O questionário foi desenvolvido por meio de discussões entre os participantes do módulo, em dois eventos internacionais, incluindo a autora desta tese, tendo sido adaptado aos hábitos nacionais de consumo, principalmente quanto aos produtos específicos de cada país. Os produtos foram divididos em categorias:

frescos sem processamento: grandes peças, incluindo miúdos e fígado e rins;

frescos minimamente processados: carne fresca que já recebeu um tratamento mecânico, como moída ou cortada em pedaços; 
frescos mas processados: produtos ondem que a carne é menos visível, tendo recebido algum tratamento ou tendo sido adicionados outros produtos, como farinha de rosca no empanado;

$>$ pratos: pratos pré-preparados à base de suínos;

$>$ produtos de carne: todo tipo de carne processada (curada, defumada, etc.).

O comportamento do consumidor em relação à carne suína foi medido usando uma escala de frequência no consumo. As maneiras e a frequência com que a carne suína entra na alimentação, em que momentos do dia ou da semana isso ocorre, na companhia de outras pessoas/famílias/amigos, local do consumo (restaurante, casa, trabalho) e tipo do produto (diferença entre pratos feitos especificamente com carne suína e outros pratos em que a carne suína é "escondida") foram investigados.

Os resultados obtidos até o momento têm cumprido os objetivos propostos de entendimento do relacionamento dos cidadãos europeus, do Brasil e da China com a produção de suínos e os problemas do setor nos próximos anos.

No Brasil, os dados já foram concluídos e enviados à coordenação do módulo, porém nem todos foram analisados. As análises já realizadas pela equipe da qual fazem parte a pesquisadora desta tese e seus orientadores constam em um relatório feito para o Projeto Q-Pork Chains, chamado: "Pork consumption in Europe and Beyond: Comprehensive Report - Part B - Pork consumption in Brazil".

Apesar de haver utilizado os dados coletados no âmbito do projeto, esta tese realizou suas análises com base nos objetivos propostos especificamente para ela, que são diferentes dos objetivos do projeto.

O Apêndice B traz um quadro-resumo com alguns dos artigos e trabalhos feitos no âmbito do projeto na área de Marketing. 


\section{REVISÃO BIBLIOGRÁFICA: DESCRIÇÃO DO SISTEMA AGROINDUSTRIAL DA CARNE SUÍNA NO BRASIL}

\subsection{O SAG}

O estudo de cadeias e sistemas agroindustriais (SAGs) não é novo. Desde que Davis e Goldberg (1957) proferiram o termo agribusiness pela primeira vez, em 1957 na Universidade de Harvard, para denominar o conjunto de todos os SAGs de diversos produtos, ele foi firmado a partir de uma série de publicações posteriores no Brasil e no exterior (GOLDBERG, 1968; ARAÚJO et al, 1990; FARINA; ZYLBERSZTAJN, 1993; ZYLBERSZTAJN, 1993, 1995; ZYLBERSZTAJN; FARINA, 1997; NEVES et al, 2000).

No Brasil, adotou-se o termo agronegócio na falta de uma palavra que melhor traduzisse o agribusiness, definido por Shelman (1991, p.48) como "uma cadeia vertical de alimentos e fibras, inter-relacionada e interdependente, começando com o fornecedor da fazenda e terminando com o consumidor final".

A partir do estudo do agronegócio como um sistema composto por vários segmentos interligados é que se percebe a importância, para todos os participantes, de incluir nele o consumidor final como o principal ator do sistema. "O sistema de agribusiness existe para o propósito último de satisfazer as necessidades de alimentos e fibras do consumidor” (SHELMAN, 1991, p. 48).

Tendo como origem a Escola de Administração da Universidade de Harvard, o conceito de agribusiness propõe uma visão sistêmica do funcionamento das atividades relacionadas à agropecuária. Em seu conjunto, o agribusiness é composto por vários sistemas agroindustriais associados aos principais produtos. Sistema agroindustrial refere-se a um recorte feito em um determinado produto dentro do agribusiness ou agronegócio. Inclui todas as fases desde a produção de insumos até o consumidor final e pode ser visto como composto por seis conjuntos de atores: 1) agricultura, pecuária e pesca; 2) indústrias agroalimentares; 3) distribuição agrícola e alimentar; 4) comércio internacional; 5) consumidor; 6) indústria e serviços de apoio (BATALHA; SILVA 2007). 
As tecnologias utilizadas nas diferentes fases de um SAG podem ser adquiridas ou copiadas, e o produtor que não tem acesso a elas, por falta de recursos ou de escala, está seriamente prejudicado. Saber o que o consumidor deseja, como está mudando e levar essa informação a toda a cadeia, conseguindo coordenar a produção a fim de colocar no varejo exatamente aquilo que ele espera, vem-se tornando uma vantagem bastante importante, tanto para firmas individuais quanto para sistemas agroindustriais. Adaptá-los exige a coordenação de todo o SAG, o que implica, constantemente, utilizar a troca de informações ao longo do sistema, a fim de:

- identificar as mudanças;

- internalizar a informação;

- renegociar os contratos;

- reestruturar a coordenação do SAG (ZYLBERSZTAJN, 1995, p.158-159).

Entre os órgãos de coordenação atuantes nesse setor, destacam-se as firmas, as cooperativas, as associações de empresas e mesmo o mercado, já que para a economia dos custos de transação uma das bases para o estudo de coordenação de SAGs que mais tem sido utilizadas na literatura - o mercado e a firma são alternativas para realizar as transações. Por outro lado, entre os serviços de apoio, citam-se, entre outros, o crédito, a mão de obra, o transporte, a energia, a comercialização e o marketing. (FAVERET FILHO; SIFFERT FILHO, 1998).

Trienekens e Wognun (2009) utilizam o termo gerenciamento da cadeia (chain management) ao discutir sobre o que chamamos de coordenação e afirmam que esse gerenciamento está relacionado, em termos simples, a:

1. reduzir incerteza e risco - mudanças imprevistas na oferta e demanda são uma importante fonte de ineficiências na busca, produção, marketing e logística das operações da cadeia. As crescentes preocupações sobre segurança alimentar aumentaram a necessidade de haver rastreabilidade e oferecer garantia de qualidade ao longo de toda a cadeia alimentar;

2. economizar tempo - os mercados no mundo todo estão se tornando cada vez mais dinâmicos e os ciclos de vida dos produtos ficando menores, o que requer mais flexibilidade e agilidade; 
3. reduzir custos - a troca de informação confiável e rápida entre os parceiros na cadeia melhora a eficiência industrial, reduz estoques, melhora a efetividade da distribuição e elimina desperdícios;

4. aumentar a efetividade - saber o que o consumidor deseja torna possível, para todos os parceiros da cadeia, focar mais precisamente os gostos e necessidades do consumidor;

5. adicionar valor - a inovação no desenvolvimento de novos produtos e serviços permanece sendo a única fonte sustentável de vantagem competitiva, difícil de atingir, mas também a mais difícil de ser copiada;

6. melhorar a qualidade - a comparação de diferenças em qualidade entre as cadeias contribui com incentivos para melhorá-las.

Tomando-se como exemplo o setor de carnes no Brasil, percebe-se que existe uma considerável variedade de formas de coordenação entre seus diversos participantes, o que se traduz em sérios conflitos, como a falta de confiança entre as partes envolvidas nas transações (JANK, 1996; CALEMAN, 2010) provindas da escassez de relações duradouras entre as partes, mesmo em transações recorrentes, o que gera altos custos, como a necessidade de monitoramento e de barganha a cada nova transação.

Resulta daí uma latente necessidade de ações conjuntas no sentido de eliminar esses conflitos e produzir resultados que possibilitem ganhos a todos os envolvidos, já que a competitividade no chamado "complexo carnes" tem sido crescente, com flagrantes desvantagens para a carne de boi, especialmente em face da indústria do frango (SAAB, 1999; SAAB; CLÁUDIO, 2009). Com base nos estudos a respeito do consumidor, começa-se a perceber o que deve ser produzido, como deve ser produzido, e pode-se incluir aí um grande número de atributos ou características que valorizem o produto de maneira a aumentar a possibilidade de ele ser incluído na lista de produtos adquiridos pelo consumidor final (BARCELLOS, 2007).

Sendo a carne suína a mais consumida mundialmente (39\% do consumo total de carnes, segundo SAAB et al, 2009), seria de se esperar seu alto consumo no Brasil. Isso, no entanto, não acontece. A média de consumo mundial de carne suína em 2007 foi de 16 kg/hab/ano e, enquanto países como Áustria, Espanha, Alemanha e Dinamarca tiveram um consumo anual per capita acima de $66 \mathrm{~kg}$ (ABIPECS, 2008), no Brasil o consumo tem se mantido na média de 13 
kg/hab/ano (13,3 em 2006, 13 em 2007, 13,2 em 2008 e 13,6 em 2009, segundo o LSPS Levantamento Sistemático da Produção de Suínos (2009).

$\mathrm{O}$ aumento no consumo de qualquer tipo de produto (em especial dos alimentos) certamente traz benefícios a toda uma cadeia agroindustrial. Afinal, é com base no consumo que se comunica para as fases ou os segmentos anteriores da cadeia (varejo, atacado, indústria, produção rural, insumos) a necessidade de produzir mais ou menos do produto em questão.

Também é fundamental saber como esse produto deve ser produzido de modo a chegar ao consumidor da maneira que ele deseja (NEVES et al, 2001; NEVES, 2005). Tal processo, chamado de coordenação da cadeia, é a capacidade de descobrir o que o consumidor deseja, comunicar sua descoberta ao elo imediatamente anterior para que ele tenha condições de adaptar seu produto às novas necessidades e cuidar para que essa informação flua por toda a cadeia até seu início com base no mesmo objetivo, que deve ser sempre o consumidor final (SAAB, 1999). Assim, comparando-se o consumo brasileiro de carne suína com o de outros países, e sabendo-se que:

a) a renda nacional está aumentando e que a carne é um produto cujo consumo aumenta com a renda (FARIA et al, 2006; BARROS, 2010),

b) o Brasil é um grande produtor mundial de carne suína (o quarto maior produtor segundo a ABIPECS, 2009),

pode-se inferir que um aumento no consumo de carne suína no Brasil é possível. No entanto, conforme exposto anteriormente, não é o que vem acontecendo. Uma das hipóteses para essa estagnação nos níveis de consumo é a de que o produto não tem chegado ao consumidor da maneira como ele deseja consumi-lo (BRASIL, 2009).

O Brasil é um grande produtor de carnes suínas, bovinas e de frangos e compete diretamente com outros países no mercado internacional. Sua vantagem competitiva é fruto da grande disponibilidade de terras, mão de obra barata, elevada oferta de insumos, acesso às tecnologias de produção, além de aspectos como as estratégias empresariais e os avanços tecnológicos e organizacionais que vêm sendo incorporados ao longo das duas últimas décadas. Na produção primária, vêm ocorrendo mudanças estruturais com aumento de escala, especialização e 
tecnificação, tendências relacionadas à crescente integração com a estrutura industrial de abate e processamento (DESOUZART, 2010).

No caso da indústria dos suínos, várias mudanças ambientais vêm afetando a estratégia das empresas no Brasil. No entanto, a maior mudança nos últimos anos nesse segmento é a que vem ocorrendo ainda na imagem do produto junto ao consumidor final. Com o surgimento e o fortalecimento das grandes indústrias, houve uma grande mudança no sentido de que se passou a necessitar de uma oferta constante e com padrões definidos. Assim, as indústrias foram obrigadas a fomentar produção mais constante e de maior qualidade, mesmo porque, para oferecerem ao consumidor final o produto que este desejava, passaram a exigir esse padrão do produtor, já que, para que uma cadeia funcione de modo a oferecer ao consumidor final o produto que este necessita - objetivo principal de qualquer cadeia produtiva -, é necessário que todos os elos funcionem de maneira a seguir a mesma estratégia.

Com a governança forte das grandes indústrias, foi possível a realização de mudanças, desde a tecnologia genética dos animais, a fim de gerar ao final da cadeia produtiva um produto que tivesse os atributos que o consumidor gostaria de obter e pelo qual pagaria o valor que se queria cobrar por ele. Assim, conseguiu-se reduzir o tempo de maturação do produto (desde o nascimento do animal até o abate), o teor de gordura da carne, as condições fitossanitárias na produção, transporte, armazenagem e comercialização. No Brasil, o setor industrial ou de abate é bastante concentrado, sendo as três maiores indústrias responsáveis em 2008 por 44,13\% do total de abates de suínos no Brasil (ABIPECS, 2008). Mas essa concentração, com marcas fortes e bem reconhecidas nacionalmente, possibilitou que a carne suína e seus derivados passassem a ser não mais de comercialização exclusivamente local, mas nacional. As grandes indústrias, que seguiram a estratégia de fortalecer suas marcas e não seus produtos específicos, acabaram por trazer uma imagem de confiabilidade e segurança aos produtos in natura e aos derivados dos suínos (linguiça, presunto, salsicha).

Uma das bases dessas empresas líderes tem sido a constante inovação em produtos processados (presuntos, salsichas, mortadelas, salame) e produtos prontos para o consumo, fortemente baseados na marca da empresa. Esse mesmo grau de inovação não é encontrado na valorização da carne fresca para o mercado interno; mas a busca por mercados mais sofisticados, como o europeu ou o japonês, pode impor a necessidade de investimentos em novas linhas de produção que levem ao fornecimento de cortes nobres ao mercado interno (SAAB et al, 2009). 
Para isso, é importante a criação de um sistema de certificação que garanta ao consumidor a qualidade que ele deseja, como a iniciativa de estabelecer, em conjunto com a ABNT (Associação Brasileira de Normas Técnicas), as características mensuráveis de carcaças necessárias à produção de cortes nobres. Ações como essa, que demandam recursos (e aumentam custos), deveriam ser acompanhadas por uma promoção do certificado ou da marca, no sentido de capturar maior valor por meio de preços mais altos.

Entre as principais empresas e cooperativas agroindustriais que abatem suínos e processam sua carne no Brasil predomina o foco na marca e nos produtos processados para o mercado interno, enquanto para as exportações a atenção se volta para o custo e o respeito às questões de segurança alimentar (sobretudo sanitárias e de resíduos nos alimentos). Além da competição com outros países pelo mercado, há também a competição entre cadeias tanto no âmbito nacional como internacional (MIELE; WAQUIL, 2007; SAAB et al, 2009).

Cada vez mais a competição migrará de uma concorrência entre firmas para uma concorrência entre sistemas produtivos mais amplos que extrapolam os limites dessas empresas. Dessa forma, o desafio maior no futuro não será somente gerir eficientemente aspectos internos aos agentes do sistema, mas também gerenciar e garantir o funcionamento harmonioso e sustentável do próprio sistema (BATALHA; SILVA, 2007).

Tornar a cadeia agroindustrial eficiente e capaz de fornecer tais requisitos ao consumidor, ao mesmo tempo em que busca diminuir os desperdícios e perdas de insumos e alimentos ao longo das operações de processamento, depende de ações e práticas coordenadas de cada um de seus segmentos e agentes, além da correta gestão de bens de produção, serviços e informações. Nesse contexto, evidencia-se a importância de gerenciar a qualidade de maneira adequada ao longo das cadeias agroindustriais (BORRÁS; TOLEDO, 2006).

Segundo Caleman (2010, p.17), “a demanda por produtos de qualidade, com rastreabilidade e que atendam a padrões socioambientais somente será atendida por meio de uma adequada coordenação com a produção. Esse novo contexto impõe desafios à coordenação como fator gerador de competitividade".

De acordo com Borrás e Toledo (2006), a maior facilidade de acesso aos mais variados tipos de informações, a crescente preocupação com a saúde e a evolução do conceito de gestão integrada da cadeia de suprimentos tem levado uma parcela cada dia maior de consumidores a 
demandarem alimentos que possuam as características que eles esperam encontrar, como sabor, coloração, aroma e textura adequados, assim como segurança à saúde.

\subsection{Coordenação do SAG}

É nesse contexto que está inserida a coordenação do SAG, pois para satisfazer esse consumidor é necessário um crescente gerenciamento de todos os agentes do sistema (MIELE; WAQUIL, 2007). Para isso, segundo Batalha e Silva (2007), é fundamentalmente importante que todos os agentes que o compõem conheçam com profundidade os atributos de qualidade que os consumidores buscam nos produtos e serviços disponibilizados nesse sistema.

Os mesmos autores acrescentam que a sustentabilidade do SAG, além da oferta de produtos que atendam à necessidade do consumidor, está baseada na eficiência, pois os agentes devem ser capazes de disponibilizar seus produtos com um nível adequado de qualidade e preço.

Pode-se constatar que há diversas formas de coordenação nos mais variados SAGs, por vezes descoordenados e, por outras, bem gerenciados. A coordenação estaria relacionada às diversas transações que ocorrem entre todos os agentes da cadeia, sendo responsável por sua eficácia (MIELE; WAQUIL, 2007).

Segundo Moraes e Macedo (2009), “a constituição de alianças estratégicas, sob diversos formatos de governança, visa ampliar a coordenação dos agentes sem demandar os custos administrativos e os investimentos que a internalização de outras etapas da cadeia produtiva, por um agente líder, exigiria”.

Dentre as opções estratégicas das agroindústrias, usadas principalmente pelas cadeias avícolas e suínas, estão as alianças. Uma aliança é uma associação de caráter duradouro entre fornecedores de produtos ou serviços com clientes e/ou intermediários comerciais. Ela pode contribuir para a melhoria da qualidade de atendimento aos clientes, bem como viabilizar a diminuição de estoques em pontos da cadeia de abastecimento, pela reposição contínua de produtos e entrega just in time na distribuição ao varejo (ALVES, 1997 apud CARVALHO-ROCHA et al, 2001).

Um sistema de produção agroindustrial pode ser visto como uma rede de empresas que se forma, fundamentalmente, com base em alianças estratégicas internas a sua estrutura. As alianças estratégicas podem ainda ser vistas como empreendimentos de risco ao longo de uma escala que 
vai do processo de fusões e aquisições visando ao controle total de uma cadeia (integração vertical completa) até arranjos cooperativos informais. No primeiro caso, existiria uma interdependência extremamente alta entre os vários agentes do sistema, ao passo que no segundo essa interdependência seria muito baixa (BATALHA; SILVA, 2007).

Já a cadeia aparece como uma proposta de utilização para apresentação de uma sequência de atividades, que tem como base um produto e funciona incorporada à rede produtiva. A cadeia é descrita como parte de um conjunto de atividades mais complexo e dinâmico, compreendido pela rede (STURGEON, 2000).

Tomando-se o caso da suinocultura (que não apresenta grandes diferenças em relação a outros setores agrícolas e da pecuária), a coordenação pode ser obtida por meio de contratos de prestação que visam não só manter os elos da cadeia cativos tanto às demandas das empresas quanto aos requisitos de qualidade, sanidade e padronização, mas também evitar deseconomias de escala e rigidez na gestão dos estabelecimentos e recursos (ZYLBERSZTAJN; NEVES, 2000).

A eficácia das cadeias de valor tem origem em sua eficiência sistêmica, em oposição à ideia de eficiência em um ponto da cadeia apenas (KAPLINSKI; MORRIS, 2003). Segundo Caleman (2010, p.17), “a eficiência de um SAG fundamenta-se na capacidade de criação e sustentação de valor, sendo que, a esse respeito, aspectos de coordenação são imprescindíveis".

Cadeia seria então o mapeamento de uma sequência vertical de eventos que levam à entrega, consumo e manutenção de um bem ou serviço específico. Cadeias com frequência compartilham atores (uma mesma organização pode fazer parte de várias cadeias) e são dinâmicas (mudam conforme evoluem e conforme muda o ambiente político, econômico, legal, etc.).

Apesar de a literatura privilegiar cadeias simples de valor (Figura 5), na realidade a complexidade é muito maior, principalmente porque uma empresa pode estar presente em várias cadeias ao mesmo tempo. 


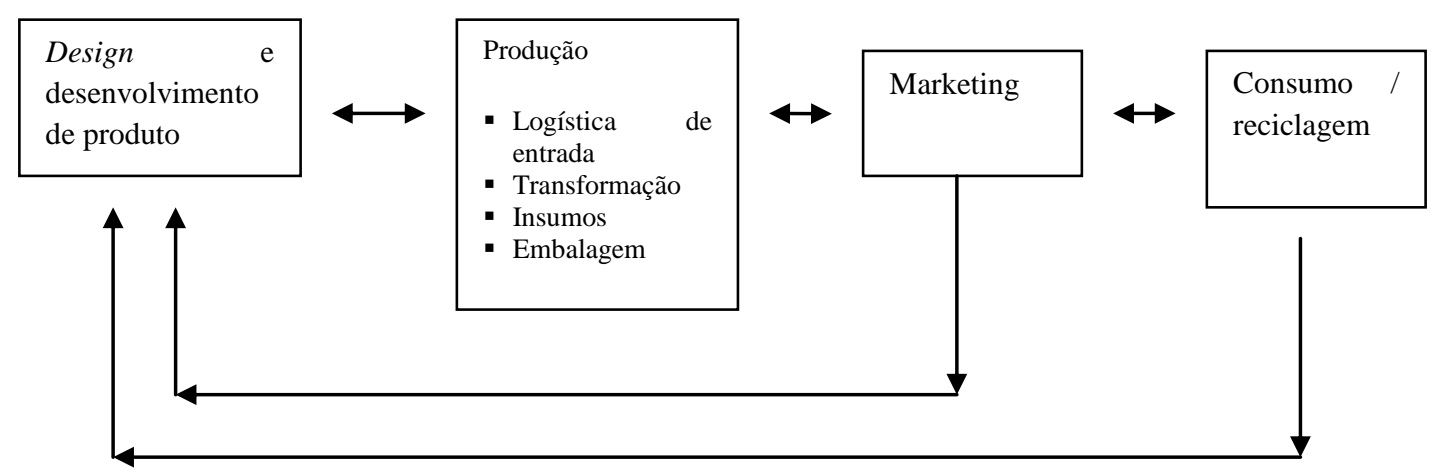

Figura 5 - Quatro elos em uma cadeia simples de valor FONTE: Kaplinski e Morris, 2003.

O conceito de cadeia global de valor (global value chain) adiciona ao conceito anterior de cadeias a conexão internacional e a governança. Trata da coordenação internacional das atividades de produção e distribuição, que explica sua existência e varia em função da centralização dos sistemas de coordenação e dos agentes dominantes. Além disso, suas características dependem da intensidade do capital, custos de transação e do trabalho (WHITLEY, 1996).

Um breve desenho da cadeia de suínos no Brasil procura mostrar sua real dimensão no país. 


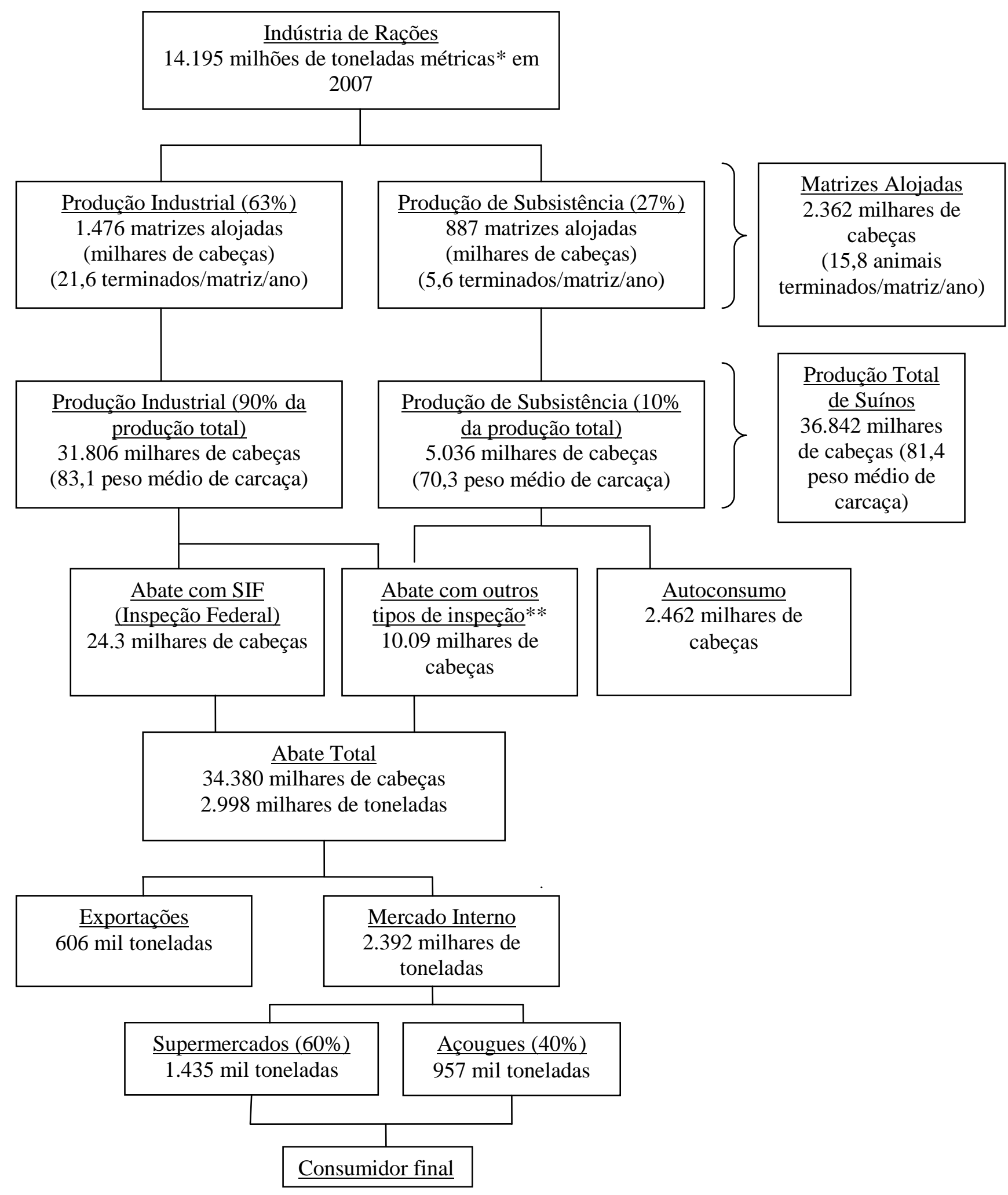

Figura 6 - Cadeia dos suínos no Brasil 
FONTE: SAAB; NEVES, 2009, p. 248.

Notas: * toneladas métricas: A tonelada métrica, cujo símbolo é t, consiste numa unidade de massa que não pertence ao sistema internacional (SI) e é equivalente a $10^{3} \mathrm{~kg}$. Por razões de extensão, o sistema internacional permite utilizá-la juntamente com suas unidades de massa.

**existem no Brasil estabelecimentos inspecionados por órgãos municipais (SIM - Sistema de Inspeção Municipal) e estaduais (SIE - Sistema de Inspeção Sanitária do Estado). A carne oriunda desses estabelecimentos somente pode ser comercializada no âmbito da inspeção a que foi submetida. Assim, os estabelecimentos inspecionados pelo sistema municipal são autorizados, apenas, a comercializar seus produtos dentro do próprio município. Já a carne oriunda de estabelecimento inspecionado pelo estado pode ser comercializada apenas no âmbito estadual. Somente a carne inspecionada pelo SIF (Sistema de Inspeção Federal) pode ser comercializada em nível nacional e para exportação.

\subsection{O Mercado da Carne Suína no Brasil - Consumo}

Apesar de ser a carne mais consumida no mundo (15,2 kg/hab/ano em 2009, de acordo com ROPPA, 2010a), o consumo de carne suína ainda ocupa apenas o terceiro lugar no Brasil. O consumo anual em 2009 foi de apenas 13,8 kg/hab/ano (PORKWORLD, 2010; ABIPECS, 2010), bastante baixo se comparado ao consumo no país de carne de frango e bovina (37 e 36 $\mathrm{kg} / \mathrm{hab} / \mathrm{ano}$ respectivamente, de acordo com ANUALPEC, 2009).

À medida que cresce a renda da população, no entanto, a tendência é que a qualidade da alimentação das pessoas melhore de uma maneira geral e, nesse contexto, a carne tem grande vantagem, já que normalmente é um item caro na cesta de consumo do consumidor de alimentos. Segundo Roppa (2010b), projeta-se entre 1990 e 2050 um crescimento no PIB mundial de US\$ 4.535,00 para US\$ 11.248,00, o que geraria um aumento no consumo de carnes de 34,1 kg/hab/ano para 68,8 kg/hab/ano. No caso da carne suína, entre 2007 e 2019, o consumo mundial passaria de 15,2 kg/hab/ano para 16,6 kg/hab/ano, concentrados nos países em desenvolvimento, que teriam um crescimento de 2,3\% ao ano (de 2010 a 2019), principalmente pelo aumento na população, crescimento da renda per capita, urbanização e mudanças nos hábitos alimentares.

Esse fenômeno vem ocorrendo também no Brasil. Porém, não se percebeu ainda um grande incremento no consumo de carnes em geral. Além do fator preço, uma das principais razões para o baixo consumo de carne suína no Brasil é a imagem do produto como pouco saudável, gorduroso e proveniente de um animal "sujo", alimentado com sobras de alimentos, mais conhecida como "lavagem", que vive em cercados chamados de "chiqueiros" (MIELE, 2007; 
SAAB et al, 2007; CARTILHA ABCS, 2006; SAAB et al, 2009). Trata-se de uma questão cultural (ROPPA, 2005; SILVA; SILVA, 2009).

Além disso, há o problema da maneira como o produto é comercializado no ponto final de venda: porções grandes e pouco convenientes, que apenas podem ser consumidas por uma família grande (o que é pouco comum hoje em dia), e que demandam um longo tempo de preparo; baixa variedade de cortes, o que proporciona pequenas margens ao varejo, que por outro lado não tem incentivo para mudar esse cenário (BRASIL, 2009).

Interessante notar que cerca de $65 \%$ do consumo brasileiro é baseado em embutidos (ROPPA, 2005), como salsichas, salame e presunto. As principais razões por que os cortes frescos não são os preferidos podem ser explicadas por aspectos culturais e históricos relacionados à imagem que os consumidores têm a respeito do sistema de produção de suínos, conforme já descrito acima. Até a metade do século XX, o uso da gordura animal na nutrição humana era comum no Brasil. Naquele tempo, a gordura do suíno (banha) era tão importante quanto o lombo ou o pernil. Os suínos tinham apenas de 40 a 45\% de carne magra na carcaça e de 5 a 6 centímetros de gordura externa. Com o desenvolvimento da gordura vegetal, como as margarinas, a gordura do suíno deixou de ser usada. Novas raças foram selecionadas para produzir um tipo de animal com carne magra.

O resultado foi uma mudança revolucionária na cadeia produtiva do suíno no Brasil, levando ao tipo moderno de suíno encontrado nos dias de hoje: um animal com 58 a $62 \%$ de carne magra na carcaça e apenas de 1,2 a 0,8 centímetros de gordura externa (ROPPA, 2005). Além disso, cortes de lombo, pernil e paleta de suínos, comparados com os cortes tradicionais, apresentaram redução de 20 a $24 \%$ no teor de gordura e ficaram $40 \%$ mais magros quando a gordura externa foi retirada, apresentando de 3 a 5\% de gordura por 100 g (BRAGAGNOLO; RODRIGUEZAMAYA, 2001).

A despeito de todas essas melhorias tecnológicas e desenvolvimentos genéticos pelos quais a cadeia vem passando (especialmente com relação à segurança do alimento e à produção de carne magra), os produtores e a indústria ainda não foram capazes de informar, inovar e cativar os consumidores (ALTMANN, 1997; WEYDMANN, 2004; MIELE, 2006; FARIA et al, 2006; MIELE; WAQUIL, 2007).

No entanto, o Brasil é um país com dimensões continentais $\left(8.514 .876 \mathrm{~km}^{2}\right)$ e tem uma população estimada em 193.733.795 habitantes (IBGE, 2010), podendo, portanto, ser visto 
mundialmente como um importante mercado para produtos de carne suína. Segundo dados da ABIPECS, em 2010, aproximadamente 2,5 milhões de toneladas em equivalente-carcaça de carne suína serão consumidas internamente (ABIPECS, 2010) e o país ficará em quinto lugar no consumo mundial de suínos.

\subsection{O Mercado de Suínos no Brasil - Produção}

O Brasil é também um ator importante em termos de produção mundial de suínos, sendo o quarto maior produtor (MIELE, 2007; ABIPECS, 2010) e o quarto maior exportador (ABIPECS, 2010). Ao contrário da maioria dos países europeus, onde a produção de suínos vem caindo (VERBEKE et al, 2008; ELMADFA; WEICHSELBAUM, 2005), no Brasil ela vem aumentando, sendo estimado um crescimento de $24 \%$ entre 2010 e 2019 (ROPPA, 2010a).

A produção de suínos de alta qualidade, chamada produção industrial (ao contrário da produção de subsistência, principalmente destinada ao consumo dentro da propriedade rural onde acontece), cresceu 9\% em 2009, tendo atingido 2,87 milhões de toneladas e já é responsável por 90\% de toda a produção brasileira de suínos (PORKWORLD, 2010). Esses resultados foram principalmente atingidos pelo significante aumento das exportações, já que os mercados externos exigem maiores níveis de qualidade (MIELE; GIROTTO, 2008).

A produção doméstica, ou de subsistência, presente principalmente nas regiões norte e nordeste, de fato vem caindo a uma taxa de $8 \%$ ao ano aproximadamente e, ainda que represente $26 \%$ do rebanho, teve uma participação de apenas $10 \%$ da produção de suínos em 2009, enquanto correspondia a $29 \%$ da produção em 2002.

Especialistas brasileiros também investiram na evolução genética da espécie por 20 anos, o que reduziu em $31 \%$ a gordura da carne, $10 \%$ do colesterol e $14 \%$ de calorias, tornando a carne suína brasileira mais magra e nutritiva, além de saborosa (ROPPA, 2006a).

Consequência de investimento, a produção vem crescendo em torno de $4 \%$ ao ano, sendo os estados de Santa Catarina, Paraná e Rio Grande do Sul os principais produtores de suínos do país. Atualmente, o Brasil representa $10 \%$ do volume exportado de carne suína no mundo, chegando a lucrar mais de US\$ 1 bilhão por ano. 
Esses fatores apontam para um crescimento ainda mais satisfatório: estima-se que a produção de carne suína atinja média anual de crescimento de 2,84\%, no período de 2008/2009 a 2018/2019, e seu consumo, 1,79\%. Em relação às exportações, a representatividade do mercado brasileiro de carne suína saltará de 10,1\%, em 2008, para 21\% em 2018/2019 (BRASIL, 2011).

Em 2008, o valor da produção brasileira de suínos chegou a cerca de US\$3,3 bilhões. A produção alcançou 2,71 milhões de toneladas de carne (o que corresponde a 32,8 milhões de cabeças abatidas). De 2000 a 2008, a produção total de suínos no Brasil cresceu 6,4\%. De acordo com a ABIPECS (2009), desde 2004 a produção de suínos tem apresentado grande crescimento, recobrando a queda de 2002, quando foi reduzida em cerca de 2,11\% devido aos altos custos do milho e da soja, principalmente. De 2005 a 2010 esse aumento foi de 21,8\%, acompanhando o crescimento da demanda interna e das exportações.

Segundo a Abipecs (2010), "o aumento da renda interna, o crescimento da população e das exportações são os três principais fatores que têm garantido uma sólida base de expansão da cadeia produtiva".

Um processo de concentração está acontecendo, reduzindo o número de produtores de suínos dedicados à atividade, mas mantendo altos níveis de produtividade (SILVEIRA; TALAMINI, 2007). Ainda assim, segundo estimativas da Faesp/Senar (Federação da Agricultura e Pecuária do Estado de São Paulo/Serviço Nacional de Aprendizagem Rural), mais de 730 mil pessoas dependem diretamente da suinocultura no Brasil, responsável pela renda de cerca de 2,7 milhões de pessoas (NOTÍCIAS FAESP/SENAR, 2010).

Além disso, o alojamento de matrizes de subsistência vem decrescendo. De qualquer maneira, o maior impulso na produção acontece por causa do crescimento da produtividade das matrizes industriais (entre 20,5 e 23 animais terminados/matriz/ano, dependendo da região).

Novas fazendas foram criadas no lugar de outras mais antigas e menos produtivas e foram intensificados os esforços no sentido de repor os rebanhos com animais de melhor potencial genético (ABIPECS, 2007).

A organização da cadeia de suínos difere entre as várias regiões no Brasil. A região sul é bastante tradicional na produção e nela estão concentrados os maiores produtores. Santa Catarina, localizada nessa região, é o maior estado produtor do Brasil, com aproximadamente $26 \%$ do total produzido no país. Em 2007, a região sul foi responsável por 47\% da produção brasileira de suínos, seguida pelo sudeste, com 18\% (IBGE, 2007). 
No entanto, nos últimos anos, a produção vem crescendo mais no centro-oeste do que nas regiões sul e sudeste. Entre 2004 e 2007, a produção no centro-oeste aumentou 42\%, enquanto o crescimento no sul foi de $8,2 \%$. As propriedades maiores e mais profissionalizadas e a proximidade da área agrícola (especialmente grãos, como milho e soja) mais os benefícios oferecidos pelo Estado e a tecnologia avançada impulsionaram o avanço da suinocultura na região. Esses fatores têm atraído produtores e grandes empresas a se instalarem na região.

Diferentemente do centro-oeste, o sul tem uma tradição de pequenas propriedades rurais, a maioria das quais são administradas pelas próprias famílias proprietárias. De acordo com a Scot Consultoria (2009), 81,7\% do rebanho suíno está localizado em propriedades com menos de 100 hectares e cerca de $40 \%$ dos produtores são integrados. Os outros $60 \%$ representam produtores independentes.

Produtores integrados têm acordos contratuais com a indústria, o que pode ser caracterizado por diferentes modelos de relacionamento. Os produtores independentes não têm nenhum acordo com a indústria, enquanto os chamados semi-integrados adquirem animais de terceiros para engorda ou venda. Em Santa Catarina, 82\% do total dos abates são originados de sistemas de integração. Os outros $18 \%$ são representados por produtores independentes.

Os custos de produção em Goiás (que se localiza na região centro-oeste) são normalmente mais altos que em Santa Catarina. Apesar dos custos mais baixos de alimentação em Goiás (o custo da ração de suínos era 5,4\% mais alto em Santa Catarina), os investimentos realizados na moderna estrutura de produção (instalações e equipamentos) em Goiás aumentam os custos fixos (CONSOLI et al, 2010).

O custo total de produção em Goiás em 2008 era 5\% mais alto que em Santa Catarina. Mas a estrutura de custo é bastante similar em ambos os estados: entre 70 e $78 \%$ dos custos totais referem-se a alimentação; de 6 a 7\% refere-se a mão de obra; de 3 a $6 \%$ a transporte; e de 2 a 3\% a produtos de saúde animal.

O custo do animal vivo no Brasil é o menor do mundo de acordo com estudos comparativos. É o mais barato mesmo quando comparado com outros grandes produtores, como China, Estados Unidos e Canadá. Comparando-se com a Europa, a diferença é maior ainda.

São também fatores de competitividade do Brasil a constante atualização do parque industrial nacional, principalmente pela indústria exportadora, e a mentalidade de usar todo o peso do animal vivo, enquanto outros países consideram muitas das saídas do processo industrial como 
subprodutos (MOURA et al, 2009; DESOUZART, 2009). No Brasil, todas as partes do suíno são utilizadas, o que torna o país altamente competitivo até a saída das granjas industriais de suínos. No entanto, a partir daí perde-se competitividade (estradas ruins, portos ineficientes, carga fiscal excessivamente elevada, os caminhões brasileiros duram menos que os de outros países, também devido às más condições de conservação das estradas). Muito do que se ganha no campo e indústria, perde-se com problemas no ambiente institucional (NORTH,1990), que é marcado por disputas entre o governo e a iniciativa privada, no sentido de que ambos julgam ser falha alheia os problemas estruturais encontrados principalmente quanto à estrutura logística nacional.

Entre 2006 e 2007, houve um crescimento de cerca de 4 a 5\% ao ano da oferta de carne suína na produção industrial e de 2 a $3 \%$ no rebanho total. Considerando dados do Departamento de Agricultura dos Estados Unidos (USDA, 2007) para os principais produtores e exportadores, o Brasil tem tido o mesmo desempenho que os Estados Unidos e Canadá, países considerados modelos de produção, juntamente com a Dinamarca, passando de 2,99\% da produção mundial em 2006 para 3,17\% em 2007.

Diretamente relacionada a melhoramentos genéticos, a inseminação artificial vem sendo largamente utilizada em sistemas de produção tecnicamente avançados. A inseminação artificial permite a rápida difusão das características desejadas no rebanho, a padronização da produção, melhor uso de capados superiores, entre muitas outras vantagens. Além disso, esse aumento confirma o crescimento no Brasil da suinocultura industrial, que se utiliza basicamente desta técnica, com o fim de obter maior padronização de seu rebanho. Por sua vez, na suinocultura de subsistência a inseminação artificial não é utilizada, e as consequências são inúmeras, inclusive a falta de padronização do rebanho e posteriormente da qualidade da carne.

A nutrição também tem apresentado grande progresso, com várias técnicas de análise de alimentos, sendo hoje uma ferramenta fundamental para a produção de suínos. A base de sua alimentação hoje no Brasil são o milho e a soja, suplementados por minerais e vitaminas. A incerteza dos preços desses cereais, porém, é uma grande vulnerabilidade, já que a alimentação representa cerca de 70\% do total dos custos de produção (MARKESTRAT, 2009). 


\subsection{Mercado Externo}

A carne suína tem uma produção mundial de 115 milhões de toneladas (ABIPECS, 2010). No entanto, é tradicionalmente um produto de comercialização interna, já que existe produção de suínos em quase todos os países do mundo (SORENSEN, 2007). Comparado ao de outros tipos de carnes, o comércio internacional é baixo, sendo que apenas 5,5\% da produção mundial de carne suína são comercializados internacionalmente, segundo o FAO Outlook (OECD-FAO AGRICULTURAL OUTLOOK 2009), bastante abaixo dos $10 \%$ das carnes bovina e de frango. Assim mesmo, o comércio internacional de carne suína movimenta 5,4 milhões de toneladas e gera uma receita anual de aproximadamente US\$ 11,9 bilhões, bastante concentrado em cinco países importadores (Japão, Federação Russa, México, Coreia do Sul e Hong Kong). Os Estados Unidos, a União Europeia, o Canadá, o Brasil e a China são responsáveis por $96 \%$ das exportações mundiais (ABIPECS, 2010).

O Brasil tem aumentado sua participação no mercado mundial, passando de $4 \%$ em 2000 para $11 \%$ em 2009. Assim, o país participa atualmente com 3\% da produção e $11 \%$ das exportações mundiais. As exportações têm crescido, apesar do grande número de barreiras comerciais e sanitárias impostas pelos países importadores, do aumento dos subsídios dos países europeus e do crescimento da concorrência internacional (ABIPECS, 2010).

Esse aumento deve-se basicamente às estratégias das empresas e aos avanços tecnológicos e organizacionais incorporados por elas e por toda a cadeia nos últimos anos (MIELE; WAQUIL, 2007), adequando-se aos países importadores e conquistando novos mercados.

Comparando com 1997, quando o país havia exportado 64 mil ton., o crescimento é de 900\%, em um período de 10 anos (ABIPECS, 2008). O fato de o preço médio ter aumentado 33,2\% de 2005 a 2007 também merece atenção e pode ser explicado, entre outros fatores, pela mudança na carne exportada, que costumava ser basicamente meias carcaças e atualmente compõe-se principalmente de cortes nobres e processados.

Tal fato explica-se pelos altos preços do mercado internacional e também pelas estratégias particulares das empresas, que priorizaram preço em vez de volume. 


\section{HIPÓTESE DE PESQUISA}

Com base no referencial teórico exposto até aqui, e após uma breve caracterização do SAG da carne suína no Brasil, pretende-se agora apresentar a hipótese que será testada neste estudo. Acredita-se que as atitudes dos consumidores brasileiros de carne suína em relação ao meio

ambiente e à natureza, à produção industrial de alimentos, ao progresso tecnológico e ao etnocentrismo sejam influenciadas pelos conceitos do Food Related Lifestyle (FRL - estilo de vida relacionado a alimentos) e Portrait Values Questionnaire ( $P V Q$ - questionário de valores ilustrados). Tanto essas atitudes, quanto os próprios conceitos de $F R L$ e $P V Q$ influenciam a maneira como o consumidor vê a produção de suínos. Somados todos esses fatores, são gerados os comportamentos de consumo do consumidor final de carne suína no Brasil.

\subsection{O Modelo da Pesquisa}

A Figura 7 traz um esquema que facilita a visualização da hipótese na qual se baseia o presente estudo. 

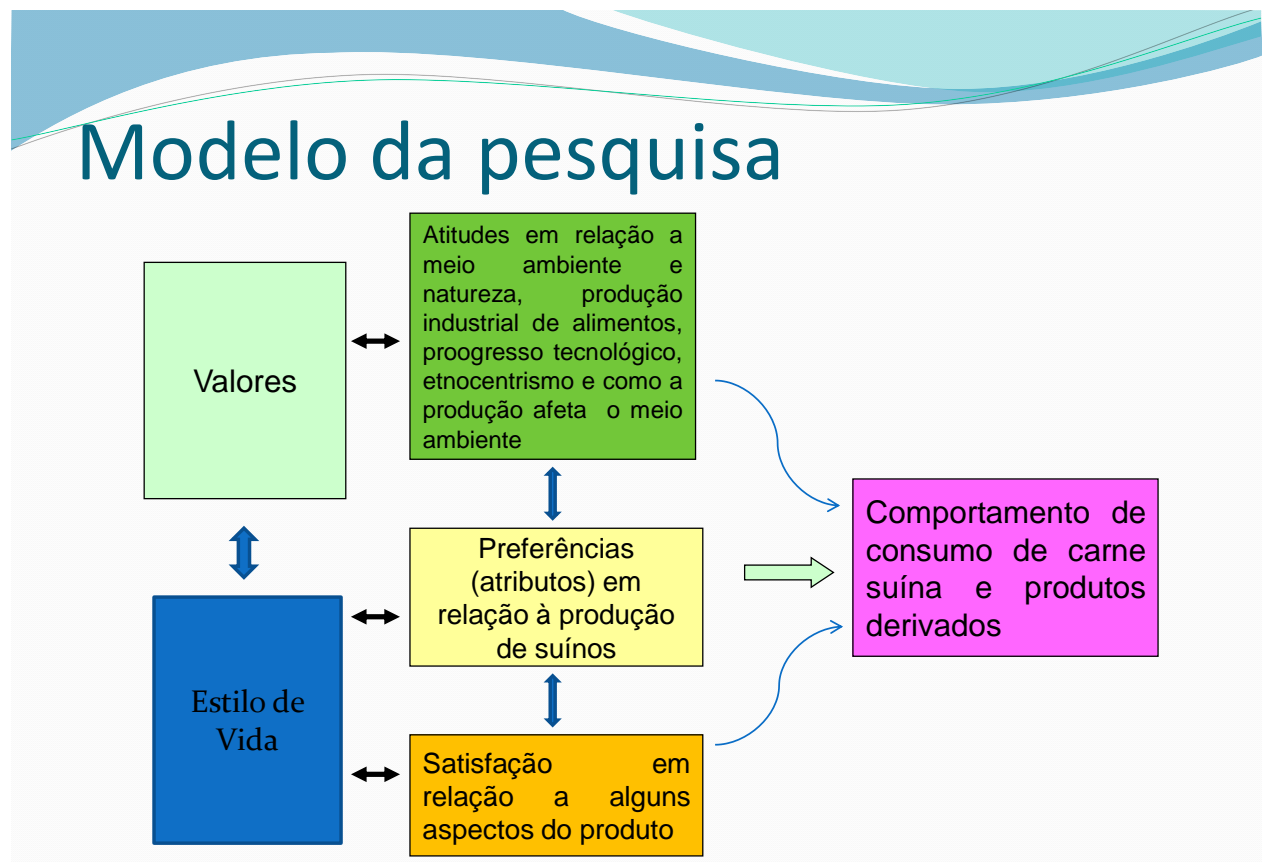

Figura 7 - O modelo da pesquisa 


\section{METODOLOGIA}

\subsection{Introdução}

A apresentação do método de pesquisa pressupõe uma descrição detalhada de todas as atividades e procedimentos adotados durante a realização do estudo (BARCELLOS, 2007).

De acordo com Rudio (1986), com o fim de conhecer a realidade empírica, a ciência utiliza a pesquisa, que, dentre outras formas, pode ser descritiva ou experimental. "A primeira tem por objetivo obter informação do que existe, a fim de poder descrever e interpretar a realidade"(RUDIO, 1986, p. 14). Já a experimental se interessa em ir mais além e interferir ou modificar os fatos, criando condições para tal. Assim, além de descrever os fenômenos como existem na realidade, a pesquisa experimental procura explicar o que ocorre quando dois ou mais fenômenos são relacionados, ou seja, o pesquisador manipula deliberadamente algum aspecto da realidade, dentro de condições previamente definidas, para observar se produz algum efeito (RUDIO, 1986).

Segundo o mesmo autor, para ser considerada científica, a pesquisa deve ser realizada de modo

sistematizado e, ainda que enfatize o valor da criatividade, deve submeter-se "tanto aos procedimentos do método como aos recursos da técnica” (RUDIO, 1986, p. 15).

Para Gil (2006), o delineamento da pesquisa envolve tanto sua diagramação quanto a previsão de análise e interpretação dos dados e divide-se em dois grandes grupos: "aqueles que se valem das chamadas fontes 'de papel' e aqueles cujos dados são fornecidos por pessoas. No primeiro grupo, estão a pesquisa bibliográfica e a pesquisa documental. No segundo, estão a pesquisa experimental, a pesquisa ex post facto, o levantamento e o estudo de caso" (GIL, 2006, p. 43).

As pesquisas bibliográfica e documental são muito parecidas, tendo como diferença a natureza das fontes. Enquanto a bibliográfica utiliza as contribuições de vários autores a respeito de determinado assunto, a documental usa material que pode ser reelaborado para adaptar-se aos objetivos da pesquisa, por ainda não ter recebido tratamento analítico (SAAB, 1999, p. 37).

O presente estudo fez uso da pesquisa bibliográfica, buscando realizar uma descrição do que tem sido feito a respeito do tema proposto, e também da pesquisa documental, quando se utilizaram 
dados estatísticos com o objetivo de fazer proposições a respeito das preferências dos consumidores.

Assim, o objetivo da pesquisa seria esclarecer questões com a finalidade de encontrar respostas para indagações que possam existir em todos os campos do conhecimento humano. Para aqueles que se submetem a pesquisar, há a necessidade de utilizar uma série de conhecimentos técnicos e práticos, de conhecer os métodos e outros tipos de procedimentos, a fim de alcançar resultados para as questões e perguntas formuladas e planejar uma investigação de acordo com as normas da Metodologia Científica, tanto em termos de forma quanto de conteúdo (OLIVEIRA, 1999, p. 117-118).

Este estudo foi realizado em duas fases: a primeira foi elaborada utilizando-se a pesquisa exploratória com abordagem no método qualitativo; a segunda, utilizando-se características da pesquisa descritiva com abordagem no método quantitativo.

Malhotra (2001, p. 155) define o método qualitativo como: "uma metodologia de pesquisa não estruturada, exploratória [...] que proporciona insights e compreensão do contexto do problema”. Já Richardson (1985, p. 38) afirma que o método qualitativo “difere, em princípio, do quantitativo, na medida em que não emprega um instrumental estatístico como base do processo de análise de um problema", isto porque não pretende numerar ou medir unidades ou categorias homogêneas. Para McDaniel e Gates (2003), a pesquisa qualitativa pode gerar sugestões e percepções sobre um objeto, quando se deseja aprofundar alguns pontos sobre ele que ainda não estão claros.

Na revisão bibliográfica foram consultados livros, artigos, periódicos, teses e dissertações, sites na Internet e demais bases com o fim de contribuir com o estudo proposto e de ampliar as fontes de conhecimento sobre o comportamento do consumidor, sobre atitudes e sobre a TPB, especificamente.

Malhotra (2001, p. 128) afirma que as vantagens de utilizar dados secundários na concepção da pesquisa residem no fato de que estes podem auxiliar o pesquisador a desenvolver uma abordagem do problema, identificando as variáveis-chave e interpretando posteriormente os dados primários com mais critério. Além disso, foi o método utilizado para desenvolver a descrição do SAG dos suínos, com dados atualizados, baseados principalmente em relatórios de associações e revistas setoriais. 
Já Goode e Hatt (apud RICHARDSON, 1985, p. 38) entendem que a pesquisa quantitativa é também, de certo modo, qualitativa, chegando a afirmar: "A pesquisa moderna deve rejeitar como uma falsa dicotomia a separação entre estudos 'qualitativos' e 'quantitativos', ou entre ponto de vista 'estatístico' e 'não estatístico'. Além disso, não importa quão precisas sejam as medidas, o que é medido continua a ser uma qualidade".

Os dois métodos complementam-se, pois

"no planejamento da pesquisa a discussão com o grupo que participará da investigação, o uso de entrevistas e a observação podem melhorar a formulação do problema, o levantamento de hipóteses e a determinação da amostra. [...] o questionário prévio pode ajudar a identificar características objetivas [...] que podem influir no contexto da pesquisa. $\mathrm{Na}$ análise da informação, as técnicas estatísticas podem contribuir para verificar informações e reinterpretar observações qualitativas, permitindo conclusões mais objetivas" (RICHARDSON,1985, p. 48).

Segundo Malhotra (2001), as vantagens de usar conjuntamente os dois métodos - qualitativo e quantitativo - residem no fato de poder-se verificar a representatividade e validade dos pontos levantados na pesquisa qualitativa; explicar resultados obtidos pela pesquisa quantitativa e, finalmente, enriquecer a visão do pesquisador quanto ao contexto pesquisado.

A Figura 8 traz uma breve descrição das etapas do trabalho. 
ETAPA EXPLORATÓRIA:

•Revisão da literatura

- Identificação da teoria base do estudo

-Definição do estudo a ser replicado

-Tradução do questionário original para o português

- Adaptação do questionário para o contexto brasileiro

-Participação em eventos do setor

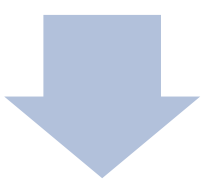

\section{ETAPA DESCRITIVA:}

-Pré-teste do questionário

•Ajuste do questionário com base no pré teste e avaliações

-Finalização do questionário

•Realização da pesquisa com consumidores

- Tratamento dos dados

-Análise dos dados

•Conclusões

Figura 8 - Etapas da concepção da pesquisa

\subsection{Etapa Exploratória}

A primeira etapa da pesquisa foi exploratória. Segundo Malhotra (2000, p. 105), o principal objetivo da pesquisa exploratória é prover a compreensão do tipo de problema enfrentado pelo pesquisador, sendo usada nos casos em que é necessário defini-lo com maior precisão, identificar cursos relevantes de ação ou obter dados adicionais, antes que se possa desenvolver uma abordagem.

Oliveira (2002, p. 134) afirma que na pesquisa exploratória "a ênfase é dada à descoberta de práticas ou diretrizes que precisam modificar-se na elaboração de alternativas que possam ser substituídas".

Utilizando a pesquisa exploratória, realizou-se a revisão da literatura, em que se buscou primeiramente fazer um breve esclarecimento sobre o tema Comportamento do Consumidor, 
com suas principais abordagens, até chegar à busca de artigos sobre o comportamento do consumidor de carnes no Brasil, além de estudos acerca do consumo de alimentos e da $T P B$ (Theory of Planned Behavior), parte da teoria do Comportamento do Consumidor escolhida para servir como base teórica do estudo. Utilizou-se nessa fase o método qualitativo de pesquisa.

Buscaram-se também dados secundários referentes principalmente ao sistema agroindustrial dos suínos, em especial dados sobre o mercado brasileiro atual. Além disso, como parte da etapa exploratória, procurou-se participar de feiras e eventos do setor, inclusive com a realização de algumas palestras sobre o assunto.

Outra ação importante como parte dessa fase foi a participação nas reuniões anuais realizadas pelo projeto $Q$-PorkChains, descritas a seguir:

1. Reunião anual realizada em Monnels, Espanha, no IRTA (Institut de Recerca $i$ Tecnologia Agroalimentàries), em novembro de 2007. Esta reunião, chamada de General Assembly (GA), reúne todos os participantes do projeto e foi a primeira após seu início, em janeiro de 2007. Nela a pesquisadora fez uma apresentação sobre o SAG dos suínos no Brasil, com o objetivo de passar aos demais participantes do Módulo I - Consumer/Market Analysis alguns dados que lhes permitissem contextualizar o Brasil no cenário mundial de carne suína para poderem contribuir nas discussões a respeito da adaptação do Questionário Master ao contexto brasileiro. Sobre os itens demográficos, em especial o nível educacional, determinaram-se as categorias referentes ao Brasil (ensino fundamental incompleto / ensino fundamental completo / ensino médio completo / faculdade e além). Sobre o FRL (Food Related Lifestyle): existem 23 dimensões - decidiu-se checar se alguma das dimensões era irrelevante ou se necessitava de mudanças - especialmente na parte sobre o ato de cozinhar. Sobre os itens dos valores de Schwartz, decidiu-se que não deveriam ser mudados, já que são bastante genéricos e testados em todo o mundo. Decidiu-se contatar o prof. Salom Schwartz diretamente e pedir uma tradução já pronta para o português, o que foi feito pela pesquisadora. Quanto às questões sobre atitudes, estavam corretas. Questionou-se ainda se as questões sobre bem-estar animal seriam válidas no Brasil, sendo observado por estudos anteriores (BARCELLOS, 2007) que não eram e portanto foram retiradas do questionário brasileiro, assim como foi feito 
com as questões sobre biotecnologia animal. Isso também facilitaria a aplicação do questionário, já que encurtaria o tempo da entrevista. No Brasil, diferentemente da Europa e por questões culturais, esta seria feita por meio de entrevistas pessoais. As partes sobre etnocentrismo e proteção ao meio ambiente foram mantidas e a parte da conjoint analysis (sistemas de produção animal) necessitava adaptação ao contexto brasileiro, uma vez que nem todos os itens/atributos/níveis fazem sentido no Brasil (por exemplo, o número médio de matrizes por propriedade rural). Na parte de produtos, várias mudanças também tiveram de ser feitas.

2. Reunião do Módulo I realizada no MAPP - Universidade de Aarhus, em Aarhus, na Dinamarca, em março de 2008. Tratou-se de uma reunião interna entre os participantes do Módulo I, em que se discutiram alguns aspectos práticos a respeito da realização da pesquisa. Além disso, o encontro possibilitou à pesquisadora conhecer in loco o lugar e toda a equipe participante do Módulo, inclusive a coorientadora deste trabalho, que havia iniciado há pouco como participante do projeto, pela Universidade de Aarhus.

3. Reunião Geral realizada em Rennes, na França, no INRA (Institut Nacionale de Recherche Agroalimentaire), em outubro de 2008. Nesta reunião os coordenadores da cada módulo fizeram apresentações com o intuito de mostrar a todos os participantes do projeto o que seu módulo em particular estava realizando. Com essas reuniões gerais anuais, possibilita-se a todos os participantes do projeto o conhecimento do trabalho como um todo e permite-se verificar possibilidades de ajuda mútua ou trabalhos em conjunto, já que se trata de um trabalho que integra áreas bastante diferentes entre si, porém todas com o objetivo comum de melhorar a qualidade da carne suína para o consumidor final.

4. Reunião Geral realizada em Bonn, na Alemanha, em novembro de 2009. Esta reunião, organizada pela Universidade de Bonn, realizou também a chamada Meat Week, da qual fez parte um seminário (Mid Term Seminar) com a participação de empresas do setor e a apresentação de trabalhos dos estudantes de pós-graduação 
participantes do projeto. Assim, a pesquisadora teve a oportunidade de apresentar um trabalho no formato de pôster, com as principais atividades já realizadas no âmbito do projeto.

Além dessas reuniões, a pesquisadora foi convidada a apresentar os resultados obtidos no projeto em um importante evento do setor de suínos no Brasil, a Pork Expo 2008, realizada em Curitiba, Paraná, em outubro de 2008. A partir dessa palestra, ocorrida no estande da ABCS (Associação Brasileira dos Criadores de Suínos), a pesquisadora foi entrevistada pela revista Pork World, uma conceituada e respeitada revista do setor, para a qual descreveu detalhadamente o projeto e os resultados obtidos, e também foi convidada a proferir palestra na sede da APCS (Associação Paulista dos Criadores de Suínos), em Campinas, São Paulo, em novembro de 2008.

Uma realização bastante importante derivada do estudo dos suínos foi a participação, em coautoria com o prof. Marcos Fava Neves, orientador desta tese, de um capítulo do livro European pork chains - Diversity and quality challenges in consumer-oriented production and distribution, em que se descreveram as cadeias de suínos do Brasil e Canadá. O livro foi publicado pela Wageningen Academic Publishers, da Holanda, em março de 2009.

\subsection{Etapa Descritiva}

Nesta etapa partiu-se para a fase aplicada do trabalho, com a finalização e aplicação do questionário, que foi precedida por um pré-teste. Por ser participante do projeto, esta pesquisadora participou também da elaboração do questionário, discussões sobre a necessidade de adaptação aos diferentes países onde foi aplicado, análises iniciais dos dados obtidos, cumprindo os objetivos específicos do projeto. No entanto, para a elaboração da tese foram propostos objetivos distintos daqueles determinados pelo projeto a fim de que, ainda que se utilizassem os mesmos dados, fossem feitas abordagens diferentes e específicas para a tese.

Por tratar-se de um questionário que envolve uma série de assuntos bastante distintos entre si, diferentes análises foram feitas para cada um deles, como estatística descritiva, análise fatorial, 
análise de correlação, análise conjunta, cada uma delas explicada no decorrer da apresentação dos resultados.

\subsubsection{O questionário}

Segundo Malhotra (2001, p. 179), o método de levantamento de dados (survey) consiste em "um questionário estruturado dado a uma amostra de uma população e destinado a coletar informações específicas dos entrevistados”.

O método survey baseia-se em entrevistar os participantes por meio de várias perguntas sobre suas atitudes, motivações e características demográficas. Neste estudo, o questionário estruturado permitiu a padronização na coleta e tabulação dos dados, apresentando as questões em uma ordem predeterminada e com respostas fechadas. As vantagens referentes ao método residem na simplicidade da aplicação e na confiabilidade dos dados, uma vez que as respostas são limitadas às alternativas mencionadas.

Uma das desvantagens desse método é que nem sempre os entrevistados podem ser capazes de responder as perguntas estipuladas e, assim, com as questões estruturadas e com as alternativas de resposta fixa, o resultado pode ser a perda de validade em certos tipos de dados.

Outra limitação do método, apontada por Richardson (1985), Churchill (1991) e Malhotra (2001), é a formulação adequada das escalas ou perguntas. Sobre esses dois pontos, e com o agravante de ter-se um questionário formulado em inglês para posterior tradução para o português, tentou-se minimizar as limitações do uso desse método por meio dos pré-testes, além de intensa discussão entre os participantes do projeto.

Um ponto importante foi o treinamento dos entrevistadores, uma vez que a pesquisa era longa, e portanto teria de ser feita de maneira a minimizar os efeitos do cansaço de ambos, entrevistador e entrevistado.

Malhotra (2001) comenta que, a despeito dessas desvantagens, a abordagem de survey ainda é o método mais comum e utilizado para coleta de dados em estudos mercadológicos.

Com base nos objetivos do projeto, e particularmente nos objetivos do Módulo I Consumer/Market Analysis, foi desenvolvido um questionário para medir o sistema de atitudes e valores dos cidadãos com respeito à carne suína e o comportamento de consumo com respeito a 
produtos em que a carne suína é um componente importante, incluindo medidas de estilo de vida relacionado a alimentos (FRL-Food Related Lifestyle) e dados demográficos.

O questionário foi desenvolvido pelos participantes do Módulo I do projeto Escola de Negócios da Universidade de Aarhus, na Dinamarca (sob a coordenação do Professor Klaus Grunert, Coordenador do Módulo I); Universidade de Ghent, na Bélgica (sob a Coordenação do Professor Wim Verbeke, Líder do WorkPackage I.1, responsável pela elaboração e aplicação do questionário); Universidade Agrícola de Atenas, na Grécia (sob a coordenação do Professor George Chryssochoidis, responsável pela análise dos dados referentes às atitudes do consumidor como cidadão); Universidade de Nápoles, na Itália; e Universidade de São Paulo, no Brasil, além da Vion Foods, grande empresa holandesa no setor de alimentos; Danish Crown, empresa dinamarquesa do setor de alimentos; e Matforsk, da Noruega (empresa de consultoria e pesquisa no setor de alimentos).

Sendo o inglês o idioma oficial de todo o projeto, o questionário Master foi desenvolvido nessa língua e posteriormente traduzido para as línguas nacionais dos países onde foi aplicado (Dinamarca, Bélgica, Grécia, Polônia, Alemanha, China e Brasil) pelo procedimento da tradução inversa (BRISLIN, 1970; MANEESRIWONGUL; DIXON, 2004).

Geisinger (1994) afirma que objetivando aplicar um instrumento já existente em um novo contexto, deve-se tomar o cuidado de desenvolver uma acurada tradução e adaptação cultural a fim de adequá-lo de forma apropriada. Para Malhotra (2006), a etapa de validação do conteúdo serve para que se possa averiguar se os itens das escalas utilizadas correspondem ao construto que está sendo mensurado naquele instrumento.

É importante notar que o questionário tem como objetivo principal mapear a maneira como produtos à base de carne suína entram nos padrões de consumo de alimentos dos consumidores. Com este fim, busca-se saber quais produtos as pessoas consomem, incluindo algumas medidas de frequência, e também como, onde, com quem e para qual finalidade o produto foi comprado, preparado e consumido. Por essa razão, o instrumento não pode ser comparado a tipos de questionários de frequência comumente usados em estudos que medem a ingestão de alimentos. Por tratar-se de um instrumento novo e não facilmente comparável a outros existentes, tem uma característica bastante exploratória e de certa maneira arriscada, o que aumenta a necessidade de extenso pré-teste. 
O questionário original consistia de nove seções, das quais oito permaneceram na versão brasileira:

1) características sociodemográficas e antropométricas (peso e altura autorreportados) do respondente;

2) questões de estilo de vida relacionadas a alimentos (Food Related Lifestyle - FRL);

3) questionário de Valor Ilustrado de Schwartz (Portrait Values Questionnaire - PVQ);

4) atitudes em relação a meio ambiente e natureza, produção industrial de alimentos e progresso tecnológico;

5) etnocentrismo;

6) atitudes em relação a como a produção de alimentos afeta o meio ambiente;

7) um estudo de Análise Conjunta (Conjoint Analysis) medindo a atitude do cidadão em relação aos sistemas de produção de suínos;

8) questionário sobre o consumo de carne suína e produtos à base de carne suína incluindo questões de:

a) frequência de consumo (11 produtos/categorias de produtos, divididos em cortes frescos, frescos e pouco processados, mais processados, refeições e produtos à base de carne suína);

b) maneira como o produto é comprado ou "como compra" (fresco/resfriado ou congelado);

c) local de compra ou "onde compra" (açougue, supermercado ou outro lugar);

d) ocasiões de consumo ou "quando consome" (uma vez por semana, qualquer dia, nos finais de semana, apenas em ocasiões especiais);

e) companhia ou "com quem consome" (sozinho, com a família, com amigos, em outra companhia);

f) local de consumo ou "onde" (em casa, em restaurante, andando - para viagem -, em outro lugar);

g) como costuma preparar os produtos em casa (é preparado em casa desde o início antes de ser consumido, é finalizado em casa antes de ser consumido, é comprado pronto para o consumo).

Em seguida, havia cinco questões utilizando uma escala de 1 a 7, a satisfação em relação a:

- o produto;

- o sabor do produto;

- as características saudáveis do produto;

- a facilidade em preparar uma refeição; 
- o preço.

E finalmente, com quais produtos costuma combinar os produtos de carne suína (13 produtos, divididos em guarnições, vegetais e bebidas).

O Quadro 3 apresenta um resumo do questionário, para melhor entendimento. O instrumento de pesquisa completo está apresentado no Apêndice A. 
Quadro 3 - Construtos e instrumentos utilizados na construção do questionário aplicado nesta pesquisa

\begin{tabular}{|c|c|c|}
\hline Seção & Construto & Instrumento de medida utilizado \\
\hline 1 & $\begin{array}{l}\text { Características sociodemográficas e } \\
\text { antropométricas do respondente }\end{array}$ & Questões diretas (peso e altura autorreportados) \\
\hline 2 & Estilo de vida dos respondentes & $\begin{array}{l}\text { Questões de estilo de vida relacionadas a alimentos (Food } \\
\text { Related Lifestyle - FRL) }\end{array}$ \\
\hline 3 & Valores & $\begin{array}{l}\text { Questionário de Valores Ilustrados de Schwartz (Portrait } \\
\text { Values Questionnaire - } P V Q \text { ) }\end{array}$ \\
\hline 4 & $\begin{array}{l}\text { Atitudes em relação a meio ambiente e } \\
\text { natureza, produção industrial de } \\
\text { alimentos e progresso tecnológico }\end{array}$ & $\begin{array}{l}\text { Novo Paradigma Ambiental (New Environmental Paradigm } \\
-N E P \text { ) }\end{array}$ \\
\hline 5 & Etnocentrismo & $\begin{array}{l}\text { CETSCALE (escala de medida para o etnocentrismo do } \\
\text { consumidor) }\end{array}$ \\
\hline 6 & $\begin{array}{l}\text { Atitudes em relação a como a produção } \\
\text { de alimentos afeta o meio ambiente }\end{array}$ & $\begin{array}{l}\text { Escala de três itens, baseada em Lindeman e Väänänen } \\
(2000)\end{array}$ \\
\hline 7 & $\begin{array}{l}\text { Atitude do cidadão em relação aos } \\
\text { sistemas de produção de suínos }\end{array}$ & Análise Conjunta (Conjoint Analysis) \\
\hline 8 & $\begin{array}{l}\text { Comportamento de consumo de carne } \\
\text { suína e produtos à base de carne suína }\end{array}$ & $\begin{array}{l}\text { Questionário incluindo questões de: } \\
\text { - frequência de consumo; } \\
\text { - maneira como o produto é comprado ou "como } \\
\text { compra"; } \\
\text { - local de compra ou "onde compra"; } \\
\text { - comiões de consumo ou "quando consome"; } \\
\text { - companhia ou "com quem consome"; } \\
\text { - cocal de consumo ou "onde"; } \\
\quad \text { como costuma preparar os produtos em casa }\end{array}$ \\
\hline 9 & Satisfação & $\begin{array}{l}\text { Satisfação em relação a: } \\
\text { - } \quad \text { o produto; } \\
\text { - o sabor do produto; } \\
\text { - } \quad \text { as características saudáveis do produto; } \\
\text { - } \quad \text { a facilidade em preparar uma refeição; } \\
\text { - o preço }\end{array}$ \\
\hline 10 & $\begin{array}{l}\text { Com quais produtos costuma combinar o } \\
\text { consumo de carne suína }\end{array}$ & $\begin{array}{l}\text { Inclui algumas categorias de produtos: } \\
\text { - guarnições; } \\
\text { - } \quad \text { vegetais; } \\
\text { - } \quad \text { acompanhamentos; } \\
\text { - bebidas }\end{array}$ \\
\hline
\end{tabular}

\section{Seção 1 - Características sociodemográficas e antropométricas (peso e altura autorreportados) do respondente - Itens 0 a 9 .}

Na primeira seção do questionário estão as características sociodemográficas dos respondentes, incluindo as antropométricas (peso e altura autorreportados), nos seguintes itens: 
0. Cidade do respondente, entre oito opções: Porto Alegre, Santa Rosa, Curitiba, Ponta Grossa, Cuiabá, Campo Verde, Goiânia e Rio Verde.

1. Gênero do respondente (masculino ou feminino)

2. Ano de nascimento

3. Estado civil (casado; não casado, mas morando junto; solteiro vivendo sozinho; divorciado; ou viúvo)

4. Escolaridade (fundamental incompleto; fundamental completo; ensino médio completo; faculdade ou pós-graduação)

5. Ocupação atual (10 opções, como produtor rural autônomo ou integrado; autônomo; estudante ou não trabalhando)

6. Peso em quilos autorreportado

7. Altura em centímetros autorreportada

8. Local de moradia do entrevistado, entre cidade grande, subúrbio de cidade grande, cidade pequena, fazenda

9. Quantas pessoas moram na residência, em cada uma dentre algumas faixas etárias apresentadas

10. Questões sobre a posse de itens no domicílio, para classificação econômica do respondente. Utilizou-se o Critério de Classificação Econômica Brasil (CCEB) ${ }^{5}$

\section{Seção 2 - Questões sobre o estilo de vida dos respondentes - Itens 1 a 69}

O instrumento utilizado para medir o estilo de vida do respondente em relação a alimentos foi o $F R L$, já descrito no item 2.5 deste trabalho.

Foi utilizada uma escala Likert de 7 pontos, onde 1 significa "discordo totalmente" e 7 significa "concordo totalmente", podendo também ser utilizado um número intermediário, entre o 1 e o 7 , o 4 significando "não concordo nem discordo".

As dimensões utilizadas estão descritas a seguir e a escala completa está no Apêndice B.

5 O CCEB é um critério largamente utilizado por agências de comunicação, empresas de pesquisa e por grande número de empresas. Foi desenvolvido e estatisticamente validado pela Abep (Associação Brasileira de Empresas de Pesquisa). O sistema CCEB tem o objetivo de ser uma forma única de avaliar o poder de compra de grupos de consumidores. Deixa de lado a pretensão de classificar a população em termos de "classes sociais" e divide o mercado exclusivamente em classes econômicas. 
Maneiras de comprar

Esta área cobre seis fatores relacionados à maneira como o consumidor planeja e realiza suas compras:

- Importância de informações sobre o produto;

- Atitudes em relação à propaganda;

- Satisfação em fazer compras;

- Lojas especializadas;

- Critérios de preços;

- Lista de compras.

Inclui afirmações como "eu adoro comprar comida", ou "eu sempre tento conseguir boa qualidade com o menor preço".

Métodos de cozinhar

Esta área também cobre seis fatores relacionados ao ato de cozinhar, como o planejamento, interesse, e se é uma tarefa familiar, incluindo afirmações como "gosto de ter bastante tempo na cozinha" e "considero a cozinha um domínio das mulheres". São eles:

- Interesse em cozinhar;

- Busca de novas maneiras de cozinhar;

- Conveniência;

- Tarefa familiar;

- Planejamento;

- Tarefa da mulher.

\section{$\underline{\text { Aspectos de qualidade }}$}

Inclui questões sobre saúde, sabor e frescor, com afirmações como: “acho importante o sabor dos alimentos" e "prefiro os produtos frescos a enlatados e congelados": 
- Saúde;

- Relação preço/qualidade;

- Novidade;

- Produtos orgânicos;

- Sabor;

- Frescor.

\section{$\underline{\text { Situação de consumo }}$}

Refere-se a se o consumidor tem refeições "estabelecidas" ou se, ao invés disso, come várias vezes em pequenas porções durante o dia ("lanches"). Também se o respondente tem hábitos sociais em relação à alimentação, como se compartilhar refeições é um aspecto importante de sua vida social. Inclui afirmações sobre o momento do consumo do alimento e em companhia de quem se consome, com frases como: "gosto de ir a restaurantes com minha família e amigos" ou “em nossa casa, temos o costume de 'beliscar', o que substitui o horário das refeições”. São:

- Lanches X refeições;

- Evento social.

\section{$\underline{\text { Motivos de compra }}$}

Possui três fatores, com afirmações sobre segurança do alimento, autorrealização com a comida, e relações sociais: "é possível ter uma conversa agradável durante uma refeição" e ainda "uma refeição em família me dá a sensação de segurança":

- Autorrealização com a comida;

- Segurança;

- Relacionamentos sociais. 


\section{Seção 3 - Sistema de valores dos respondentes}

O sistema de valores dos cidadãos foi medido usando escala intervalar não comparativa do tipo Likert. Quase todas as escalas foram balanceadas com um número ímpar de categorias de respostas, com o ponto médio representando uma categoria neutra.

Os valores foram medidos usando o Questionário de Valores Ilustrados (Portrait Values Questionnaire-PVQ) de Schwartz (2003), em uma versão de 21 itens da versão original de 40 itens, contendo dois a três itens por valor. As questões são diferentes para homens e mulheres. A escala mede dez valores humanos básicos: poder, realização, hedonismo, estímulo, autodireção, universalismo, benevolência, tradição, conformidade e segurança.

- Poder - refere-se à importância de prestígio social e status, controle ou domínio sobre pessoas e recursos.

- Realização - refere-se à importância do sucesso pessoal pela demonstração de competência.

- Hedonismo - refere-se à importância do prazer e gratificação sensual para um indivíduo.

- Estímulo - refere-se à importância da excitação, novidade e desafio na vida (ousadia, uma vida variada, uma vida excitante).

- Autodireção - é expressa como a importância do pensamento independente por meio da escolha de seus atos, criação e exploração.

- Universalismo - refere-se à importância de entender, apreciar, tolerar e proteger o bemestar de todas as pessoas e da natureza.

- Benevolência - diz respeito à importância da preservação e da melhoria de pessoas com as quais o indivíduo esteja em contato pessoal frequente.

- Tradição - refere-se à importância do respeito, comprometimento e aceitação dos costumes e ideias que a cultura ou religião tradicional proveem ao indivíduo.

- Conformidade - refere-se à importância da restrição de ações, inclinações e impulsos capazes de indispor ou prejudicar os outros e violar expectativas ou normas sociais.

- Finalmente, valores incluem segurança, com referência à importância da harmonia e estabilidade da sociedade, dos relacionamentos e do indivíduo. 
Todos os itens foram respondidos em uma escala de seis itens, indo de 1 ("exatamente como eu") a 6 ("não tem nada a ver comigo").

Uma desvantagem dessa escala curta é que muitos valores são medidos por apenas dois itens. Na análise fatorial confirmatória, um modelo de medida tão pequeno pode levar a sérios problemas de identificação, sendo necessário grande nível de conhecimento técnico para conseguir obter estimativas significativas com tais modelos (SCHOLDERER, 2007). Davidov et al (apud SCHOLDERER, 2007), em uma análise inicial das características do $P V Q$ de 21 itens em 20 países, escolheram uma solução bastante severa, reduzindo o número de fatores representando os tipos de valores de 10, como teoricamente postulado, para 6, o que acabou mudando o sentido inicial dos construtos. Para evitar isso, Scholderer (2007), em sua análise, mantém os 10 tipos de valores, representando-os pelos 10 fatores da teoria, e impondo restrições de identificação em partes que chamou de periféricas ao modelo de medida, evitando, assim, uma mudança no sentido dos construtos latentes.

O Quadro 4 mostra os 21 itens e as escalas.

\begin{tabular}{|l|l|l|}
\hline \multicolumn{2}{|c|}{ Quadro 4 - Valores Ilustrados de Schwartz (PVQ) } \\
\hline Escala & Item & $\begin{array}{l}\text { Um homem que acha que as pessoas devem fazer o que lhe } \\
\text { mandam. Acha que as pessoas devem cumprir sempre as regras } \\
\text { mesmo quando ninguém esteja vendo. }\end{array}$ \\
\hline Conformidade & V167 & $\begin{array}{l}\text { Um homem para quem é importante portar-se sempre da forma } \\
\text { certa. Evita fazer coisas que os outros digam que são erradas. }\end{array}$ \\
\hline Tradição & V9 & $\begin{array}{l}\text { Um homem para quem é importante ser humilde e modesto. Tenta } \\
\text { não chamar a atenção para si. }\end{array}$ \\
\hline Tradição & V20 & $\begin{array}{l}\text { Um homem que dá importância à tradição. Faz tudo o que pode } \\
\text { para agir de acordo com sua religião e sua família. }\end{array}$ \\
\hline Benevolência & V12 & $\begin{array}{l}\text { Um homem para quem é importante ajudar os que o rodeiam. } \\
\text { Gosta de zelar pelo seu bem-estar. }\end{array}$ \\
\hline Benevolência & V18 & $\begin{array}{l}\text { Um homem para quem é importante ser leal para com os amigos. } \\
\text { Dedica-se às pessoas que lhe são próximas. }\end{array}$ \\
\hline Universalismo & V03 & $\begin{array}{l}\text { Um homem que acha importante que todas as pessoas no mundo } \\
\text { sejam tratadas igualmente. Acredita que todos devem ter as } \\
\text { mesmas oportunidades na vida. }\end{array}$ \\
\hline Universalismo & V08 & $\begin{array}{l}\text { Um homem para quem é importante ouvir pessoas diferentes. } \\
\text { Mesmo quando discorda de alguém, continua querendo } \\
\text { compreender essa pessoa. }\end{array}$ \\
\hline Universalismo & V19 & $\begin{array}{l}\text { Um homem que acredita seriamente que as pessoas devem proteger } \\
\text { a natureza. Proteger o ambiente é importante para ele. }\end{array}$ \\
\hline Autodireção & V01 & $\begin{array}{l}\text { Um homem que dá importância a ter novas ideias e ser criativo. } \\
\text { Gosta de fazer as coisas à sua maneira. }\end{array}$ \\
\hline Autodireção & V11 & $\begin{array}{l}\text { Um homem para quem é importante tomar as próprias decisões } \\
\text { sobre o que faz. Gosta de ser livre e não ficar dependente dos } \\
\text { outros. }\end{array}$ \\
\hline
\end{tabular}




\begin{tabular}{|l|l|l|}
\hline Estímulo & V06 & $\begin{array}{l}\text { Um homem que gosta de surpresas e está sempre à procura de } \\
\text { coisas novas para fazer. Acha que é importante fazer muitas coisas } \\
\text { diferentes na vida. }\end{array}$ \\
\hline Estímulo & V15 & $\begin{array}{l}\text { Um homem que procura aventura e gosta de correr riscos. Quer ter } \\
\text { uma vida emocionante. }\end{array}$ \\
\hline Hedonismo & V10 & $\begin{array}{l}\text { Um homem para quem é importante passar bons momentos. Gosta } \\
\text { de tratar bem a si mesmo. }\end{array}$ \\
\hline Hedonismo & V21 & $\begin{array}{l}\text { Um homem que procura aproveitar todas as oportunidades para } \\
\text { divertir-se. É importante para ele fazer coisas que lhe dão prazer. }\end{array}$ \\
\hline Satisfação & V04 & $\begin{array}{l}\text { Um homem que dá muita importância a poder mostrar suas } \\
\text { capacidades. Quer que as pessoas admirem o que faz. }\end{array}$ \\
\hline Satisfação & V13 & $\begin{array}{l}\text { Um homem para quem é importante ter sucesso. Gosta de recer o } \\
\text { reconhecimento dos outros. }\end{array}$ \\
\hline Poder & V02 & $\begin{array}{l}\text { Um homem para quem é importante ser rico. Quer ter muito } \\
\text { dinheiro e coisas caras. }\end{array}$ \\
\hline Poder & V17 & $\begin{array}{l}\text { Um homem para quem é importante que os outros lhe tenham } \\
\text { respeito. Quer que as pessoas façam o que ele diz. }\end{array}$ \\
\hline Segurança & V05 & $\begin{array}{l}\text { Um homem que dá importância a viver num lugar onde se sinta } \\
\text { seguro. Evita tudo o que possa pôr sua segurança em risco. }\end{array}$ \\
\hline Segurança & V14 & $\begin{array}{l}\text { Um homem para quem é importante que o Governo garanta sua } \\
\text { segurança contra todas as ameaças. Quer que o Estado seja forte, } \\
\text { de modo a defender os cidadãos. }\end{array}$ \\
\hline
\end{tabular}

FONTE: Scholderer, 2007, p. 9.

\section{Seção 4 - Atitudes em relação a meio ambiente e natureza, produção industrial de alimentos e progresso tecnológico}

As atitudes em relação a cada item específico foram retiradas da literatura. Construtos relevantes incluem atitudes em relação a sistemas de produção intensiva e extensiva de suínos; importância percebida de sistemas de produção local, emprego rural, bem-estar econômico e convivência rural; atitudes com relação ao bem-estar animal; consciência ambiental; atitudes em relação a inovações e tecnologias; atitudes políticas, preocupações com as futuras gerações; e, finalmente, sistema de valores dos cidadãos.

A atitude em relação ao meio ambiente (proteção ao meio ambiente e à natureza) foi medida usando uma versão reduzida de 5 itens da escala New Environmental Paradigm (NEP - novo paradigma ambiental), de acordo com Dunlap (2000); por exemplo, "os humanos estão abusando muito do meio ambiente".

A atitude em relação à produção industrial de alimentos foi medida por 5 itens com base em Beckmann et al (2001), como, por exemplo, "a maioria dos alimentos são tão processados que perdem o valor nutricional". 
A atitude em relação ao progresso tecnológico foi medida por 5 itens de acordo com Hamstra (1991).

Diferentemente da seção referente a valores, os itens sobre atitudes foram respondidos em uma escala de 7 pontos variando de 1 ("concordo totalmente") a 7 ("discordo totalmente"), tendo sido incluída uma categoria neutra (4 - "não concordo e nem discordo").

\section{Seção 5 - Etnocentrismo}

Tratando-se de uma pesquisa (o Q-PorkChains) que envolvia a participação de respondentes de sete países de culturas distintas, e especialmente por tratar-se de três continentes diferentes (cinco países europeus, um asiático e um sul-americano), o etnocentrismo mostrou-se uma parte importante a ser investigada.

Segundo Marconi e Presotto (2005), “etnocentrismo (...) significa a supervalorização da própria cultura em detrimento das demais. Todos os indivíduos são portadores desse sentimento e a tendência na avaliação cultural é julgar as culturas segundo os moldes da sua própria" (MARCONI e PRESOTTO, 2005, p. 32).

Para investigar a respeito do etnocentrismo dos respondentes, utilizou-se parte do Consumer Ethnocentric Scale (CETSCALE - escala para medir o etnocentrismo do consumidor), de Shimp e Sharma (1987) incluindo cinco itens com respeito à economia local e três com respeito a emprego local. Por exemplo: "Consumidores brasileiros que compram produtos feitos em outros países são responsáveis por deixar os colegas brasileiros sem emprego".

Shimp e Sharma (1987, p. 280) construíram uma escala para medir o termo "etnocentrismo do consumidor", que, segundo os autores, foi adaptado do conceito original de etnocentrismo estudado há mais de 80 anos, com a finalidade de servir ao estudo do marketing e do comportamento do consumidor. Assim, o instrumento CETSCALE foi desenvolvido para medir as tendências etnocêntricas dos consumidores de adquirir produtos nacionais ou estrangeiros. 


\section{Seção 6 - Atitudes em relação a como a produção de alimentos afeta o meio ambiente}

As atitudes com relação a alimentos e meio ambiente foram medidas com uma escala de três itens obtida em um estudo maior de Lindeman e Väänänen (2000), como, por exemplo, "É importante que toda comida que eu como normalmente seja preparada de modo que não prejudique o meio ambiente".

Lindeman e Väänänen (2000) desenharam dois estudos para revisar a escala Food Choice Questionnaire (FCQ - questionário de escolha de alimentos), criada por Steptoe et al em 1995. Nessa escala, os autores avaliam nove motivos distintos na escolha de alimentos: saúde, humor, conveniência, apelo sensorial, conteúdo natural, preço, controle de peso, familiaridade e preocupação ética. No entanto, Lindeman e Väänänen julgam que o conceito de ética está subrepresentado na $F C Q$ e decidem melhorá-la incluindo questões sobre três fatores:

1. bem-estar ecológico (bem-estar animal e proteção ao meio ambiente);

2. valores políticos;

3. religião.

Destes, foram incluídos, na versão brasileira do questionário, os itens sobre proteção ao meio ambiente, um dos quais - "É embalado de maneira amigável ao meio ambiente" - fazia parte da $F C Q$ original.

\section{Seção 7 - Atitudes em relação aos sistemas de produção de suínos}

A parte referente aos sistemas de produção de suínos foi conduzida por meio de um experimento de análise conjunta (conjoint analysis $-C A)^{6}$. Entrevistas com especialistas em produção de suínos de vários países na Europa afiliados ao projeto Q-PorkChains forneceram a base da escolha dos atributos que compreendem os sistemas de produção. No estudo, os atributos escolhidos estão relacionados aos três aspectos da sustentabilidade, ou seja, o econômico, o social e o ambiental.

6 Para um melhor detalhamento da CA, ver Spers (1998) e Saab (1999). 
Vários atributos potenciais foram excluídos do estudo, como segurança e transporte, porque se presume que todos os consumidores queiram que a comida que consomem seja segura (em termos de saúde) e que ninguém queira que os animais sofram durante o transporte.

Algumas variáveis não mostraram variação entre os respondentes e, portanto, não são relevantes estatisticamente, apesar de poderem ser relevantes para as atitudes e o comportamento de consumidores e cidadãos.

Neste experimento em particular, o procedimento utilizado foi o seguinte: a todos os respondentes era apresentada uma série de sistemas de produção. Cada um dos sistemas continha uma descrição completa com cinco atributos, que definiam um sistema particular. Cada um desses atributos tinha três níveis. O respondente via uma combinação desses níveis, uma para cada atributo, e tinha de indicar o quanto gostava do sistema descrito em uma escala de menos 5 $(-5)$ a mais $5(+5)$. Os atributos eram:

a) densidade da produção ou tamanho do rebanho (DARBY et al, 2008; VANHONACKER et al, 2008; 2009);

b) tipo de piso (MILLET et al, 2005; VANHONACKER et al, 2008);

c) impacto da produção sobre o solo, água e ar (PETIT; VAN DER WERF, 2003);

d) saúde, em termos de gordura;

e) tipo de cadeia/qualidade do produto (MILLET et al, 2005).

O Quadro 5 apresenta os atributos e níveis utilizados na pesquisa.

Quadro 5 - Atributos-chave e seus níveis

\begin{tabular}{|c|c|}
\hline Atributos & Níveis \\
\hline 1. Densidade da produção & $\begin{array}{l}\text { 1. Considere uma fazenda pequena com menos de } 100 \text { suínos e outros } \\
\text { animais } \\
\text { 2. Considere uma fazenda com cerca de } 400 \text { suínos } \\
\text { 3. Considere uma fazenda com } 800 \text { suínos ou mais e trabalhadores } \\
\text { contratados }\end{array}$ \\
\hline $\begin{array}{l}\text { 2. Tipo de piso (onde os } \\
\text { suínos são alojados) }\end{array}$ & $\begin{array}{l}\text { 1. As baias na área onde os animais defecam no confinamento têm piso } \\
\text { ripado de madeira ou metal } \\
\text { 2. O alojamento é externo e tem piso de palha } \\
\text { 3. Há uma mistura de tipos de piso contendo ambos - piso ripado para a } \\
\text { área de defecação dos animais e piso de palha nas áreas externas }\end{array}$ \\
\hline & $\begin{array}{l}\text { 1. O esforço para reduzir o impacto ambiental do sistema de produção } \\
\text { no solo, água e ar é mínimo }\end{array}$ \\
\hline
\end{tabular}




\begin{tabular}{|c|c|}
\hline $\begin{array}{l}\text { 3. Impacto no solo, ar e } \\
\text { água }\end{array}$ & $\begin{array}{l}\text { 2. Existe algum esforço para reduzir o impacto ambiental do sistema de } \\
\text { produção no solo, água e ar } \\
\text { 3. O esforço para reduzir o impacto ambiental do sistema de produção } \\
\text { no solo, água e ar é máximo }\end{array}$ \\
\hline 4. Saúde - Gordura & $\begin{array}{l}\text { 1. A alimentação dos suínos visa produzir carne com um teor de gordura } \\
\text { padrão } \\
\text { 2. A alimentação dos suínos visa produzir carne com baixo teor de } \\
\text { gordura } \\
\text { 3. A alimentação dos suínos visa produzir carne com gordura saudável }\end{array}$ \\
\hline $\begin{array}{l}\text { 5. Tipo de cadeia e } \\
\text { qualidade de produto }\end{array}$ & $\begin{array}{l}\text { 1. A fazenda produz suínos com qualidade da carne similar todas as } \\
\text { vezes } \\
\text { 2. A fazenda produz suínos com qualidade da carne diferente por causa } \\
\text { de variações biológicas e mudanças nas condições locais } \\
\text { 3. A fazenda produz suínos com as qualidades demandadas apenas por } \\
\text { seus clientes principais }\end{array}$ \\
\hline
\end{tabular}

A variável dependente era: “Em uma escala de -5 a +5 , em que -5 é 'não gostei nem um pouco’, 0 é 'nem gostei nem desgostei' e +5 é 'gostei muito', quanto você gosta deste sistema de produção de suínos?”.

Os resultados deste método de classificação foram expressos em notas de utilidades parciais (part-worth) e seus desvios padrão para cada nível do fator. Já que as utilidades foram todas expressas em uma unidade comum, podem ser somadas para dar a utilidade total de qualquer combinação. Valores de utilidades mais altos indicaram maior preferência. No presente estudo, o número de estímulos potenciais (perfis completos) foi 243, o que era um número grande demais para os respondentes considerarem. O desenho fracional fatorial reduzido fornecido pelo software SPSS 16 identificou 15 combinações (cenários) apresentados aos respondentes (BARCELLOS et al, 2010), conforme demonstra o Quadro 6.

\section{Quadro 6 - Perfis completos utilizados na pesquisa}

1 - Considere uma granja com cerca de 400 suínos. Os animais são alojados em piso com palha. Há algum esforço para reduzir o impacto ambiental do sistema de produção no solo, água e ar. A alimentação dos suínos visa produzir carne com teor de gordura padrão. A granja cria os suínos sempre com qualidade da carne similar.

2 - Considere uma granja com cerca de 400 suínos. Os animais são alojados em piso ripado (de madeira ou metal). O esforço para reduzir o impacto ambiental do sistema de produção no solo, água e ar é máximo. A alimentação dos suínos visa produzir carne com teor de gordura padrão. A granja produz suínos com a qualidade da carne exigida por seus clientes principais.

3 - Considere uma granja pequena com menos de 100 suínos e outras criações. Os animais são alojados em piso com palha. O esforço para reduzir o impacto ambiental do sistema de produção no solo, água e ar é máximo. A alimentação dos suínos visa produzir carne com teor de gordura padrão. A granja produz suínos com qualidade diferente por causa de variações biológicas e mudança das condições locais. 
4 - Considere uma granja com mais de 800 suínos e mão de obra contratada. Os animais têm acesso a uma área externa (ao ar livre). O esforço para reduzir o impacto ambiental do sistema de produção no solo, água e ar é máximo. A alimentação dos suínos visa produzir carne com gordura saudável (com ômega 3, por exemplo). A granja cria suínos sempre com qualidade da carne similar.

5 - Considere uma granja pequena com menos de 100 porcos e outras criações. Os animais são alojados em piso ripado (de madeira ou metal). O esforço para reduzir o impacto ambiental do sistema de produção no solo, água e ar é mínimo. A alimentação dos suínos visa produzir carne com teor de gordura padrão. A granja cria suínos sempre com qualidade da carne similar.

6 - Considere uma granja pequena com menos de 100 suínos e outras criações. Os animais são alojados em piso ripado (de madeira ou metal). Há algum esforço para reduzir o impacto ambiental do sistema de produção no solo, água e ar. A alimentação dos suínos visa produzir carne com gordura saudável (com ômega 3, por exemplo). A granja cria suínos sempre com qualidade da carne similar.

7 - Considere uma granja com mais de 800 suínos com mão de obra contratada. Os animais são alojados em piso ripado (de madeira ou metal). Há algum esforço para reduzir o impacto ambiental do sistema de produção no solo, água e ar. A alimentação dos suínos visa produzir carne com teor de gordura padrão. A granja produz suínos com a qualidade exigida apenas por seus clientes principais.

8 - Considere uma granja pequena com menos de 100 suínos e outras criações. Os animais têm acesso a uma área externa (ao ar livre). O esforço para reduzir o impacto ambiental do sistema de produção no solo, água e ar é mínimo. A alimentação dos suínos visa produzir carne com baixo teor de gordura (light). A granja produz suínos com a qualidade exigida apenas por seus clientes principais.

9 - Considere uma granja pequena com menos de 100 suínos e outras criações. Os animais têm acesso a uma área externa (ao ar livre). Há algum esforço para reduzir o impacto ambiental do sistema de produção no solo, água e ar. A alimentação dos suínos visa produzir carne com teor de gordura padrão. A granja cria suínos com qualidade diferente por causa de variações biológicas e mudança das condições locais.

10 - Considere uma granja com cerca de 400 suínos. Os animais têm acesso a uma área externa (ao ar livre). O esforço para reduzir o impacto ambiental do sistema de produção no solo, água e ar é mínimo. A alimentação dos suínos visa produzir carne com teor de gordura padrão. A granja cria suínos sempre com qualidade da carne similar.

11 - Considere uma granja com mais de 800 suínos e mão de obra contratada. Os animais são alojados em piso ripado (de madeira ou metal). O esforço para reduzir o impacto ambiental do sistema de produção no solo, água e ar é mínimo. A alimentação dos suínos visa produzir carne com baixo teor de gordura (light). A granja cria suínos com qualidade diferente por causa de variações biológicas e mudança das condições locais.

12 - Considere uma granja com cerca de 400 suínos. Os animais são alojados em piso ripado (de madeira ou metal). O esforço para reduzir o impacto ambiental do sistema de produção no solo, água e ar é mínimo. A alimentação dos suínos visa produzir carne com gordura saudável (com ômega 3, por exemplo). A granja cria suínos com qualidade diferente por causa de variações biológicas e mudança das condições locais.

13 - Considere uma granja pequena com menos de 100 suínos e outras criações. Os animais são alojados em piso ripado (de madeira ou metal). O esforço para reduzir o impacto ambiental do sistema de produção no solo, água e ar é máximo. A alimentação dos suínos visa produzir carne com baixo teor de gordura (light). A granja cria suínos sempre com qualidade da carne similar. 
14 - Considere uma granja com mais de 800 suínos e mão de obra contratada. Os animais são alojados em piso com palha. O esforço para reduzir o impacto ambiental do sistema de produção no solo, água e ar é mínimo. A alimentação dos suínos visa produzir carne com teor de gordura padrão. A granja cria suínos sempre com qualidade da carne similar.

15 -Considere uma granja pequena com menos de 100 suínos e outras criações. Os animais são alojados em piso com palha. O esforço para reduzir o impacto ambiental do sistema de produção no solo, água e ar é mínimo. A alimentação dos suínos visa produzir carne com gordura saudável (com ômega 3, por exemplo). A granja cria suínos sempre com qualidade da carne similar.

\section{Seção 8 - Comportamento de consumo}

Para medir o comportamento de consumo, partiu-se de trabalhos anteriores sobre dietas alimentares e dados de ingestão de alimentos, usando escalas de frequência de consumo (BARCELLOS, 2007) e também das maneiras como o consumidor compra e consome a carne suína. $\mathrm{O}$ foco foi a maneira e frequência com que a carne suína entra nos padrões de consumo de alimentos dos consumidores. Dividiram-se os produtos em 11 itens, separados por tipo de produto.

1. Primeiros cortes frescos:

a. costela de porco;

b. paleta, lombo, bisteca;

c. pernil;

d. outros (miúdos, toucinho, rabo, orelha).

2. Frescos e pouco processados:

a. linguiças, espetinho, carne embalada a vácuo, salsichão, carne de porco moída.

3. Mais processados:

a. carne recheada, escalope, carne assada, espetinho, marinados, temperados.

\section{Refeições:}

a. lasanha, pizza, macarronada, feijoada.

5. Produtos de carne:

a. frios (salame, presunto, mortadela);

b. bacon;

c. salsichas e linguiças;

d. patê.

As dimensões incluíram: 
1. O tempo ou frequência (momento do dia, dia de semana versus final de semana, estação ou época do ano):
a. nunca;
b. 1 vez por ano ou menos;
c. várias vezes ao ano;
d. mensalmente;
e. muitas vezes no mês;
f. semanalmente;
g. muitas vezes na semana;
h. diariamente.

2. Como compra:
a. fresco/resfriado;
b. congelado.

3. Onde compra:
a. no açougue;
b. no supermercado;
c. em outro lugar.

4. Quando consome:
a. uma vez por semana;
b. qualquer dia;
c. nos finais de semana;
d. apenas em ocasiões especiais.

5. Na companhia de quem consome:
a. sozinho;
b. com a família;
c. com amigos;
d. em outra companhia.

6. Onde costuma comer:
a. em casa;
b. em um restaurante;
c. no caminho ("para viagem");
d. em outro lugar.

7. Como costuma preparar:

a. é preparado em casa desde o início, antes de ser consumido;

b. é finalizado em casa antes de ser consumido;

c. é comprado pronto para o consumo. 


\section{Seção 9 - Satisfação}

Então foram incluídas questões sobre a satisfação do consumidor em relação aos mesmos produtos, com a questão: "O quanto você está satisfeito com relação a diferentes aspectos de cada um desses produtos?", dividindo-se em:

1. o produto em geral;

2. o sabor do produto;

3. suas qualidades saudáveis;

4. a facilidade de preparar o produto, também chamada de conveniência;

5. o preço do produto.

Utilizou-se aqui uma escala Likert de 7 pontos, em que 1 é "Nem um pouco satisfeito"; 4, "Nem satisfeito nem insatisfeito"; 7 , "Muito satisfeito".

\section{Seção 10 - Com o que o respondente combina o consumo do produto}

Finalmente, foram incluídas questões sobre com quais produtos o respondente costuma combinar o consumo de carne suína e derivados:

1. Guarnições:
a. arroz;
b. batata;
c. salada;
d. massa;
e. feijão.

2. Vegetais:
a. batata-doce;
b. mandioca;
c. vegetais variados (cenoura, tomate, cebola, brócolis, ervilha);
d. acompanhamentos (condimentos, molhos, conservas, geleias).

3. Bebidas:

a. água 

b. bebida gelada (refrigerantes, sucos);
c. bebida quente (café, chá, capuccino);
d. alcoólicas (vinho, cerveja, destilados);
e. outros.

\subsubsection{Escalas utilizadas}

De acordo com Donegá (2004, p. 39), "independentemente do modelo estrutural utilizado, a forma com que se mede a atitude em relação aos objetos ou ao comportamento, é praticamente a mesma, variando apenas quanto ao tipo de resposta que se espera e quanto à técnica escolhida". Alguns autores (RICHARDSON, 1985; MATTAR, 2000; MALHOTRA, 2001) ligados à pesquisa social ou mercadológica, relacionam as escalas de Likert como escalas utilizadas para medir a atitude.

Ajzen (2002) apresenta algumas das técnicas mais utilizadas para medir atitudes ao longo da história da psicologia social, destacando como escalas mais utilizadas nos estudos sobre atitudes as escalas de diferencial semântico e Likert. O Quadro 7 apresenta as técnicas mais utilizadas para medir atitude.

\section{Quadro 7 - Técnicas comuns para medir atitude}

\begin{tabular}{ll}
\hline Tipos de Resposta & Técnica Representativa \\
\hline Explícita - direta & Autorrelato \\
Único item & Diferencial semântico \\
Múltiplos itens & Thurstone \\
Explícita - inferida & Likert \\
& Error-choice \\
Disfarçada & \\
Implícita & GSR, dilatação da pupila, batimentos cardíacos \\
\hline Respostas do corpo & \\
\hline
\end{tabular}

FONTE: Ajzen, 2002.

As escalas de diferencial semântico consistem na avaliação de determinado objeto por meio de escalas com pontos extremos associados a rótulos bipolares de sete pontos (MATTAR, 2000). Os itens individuais podem ser classificados segundo uma escala de -3 a +3 ou de 1 a 7 , e os dados 
resultantes são avaliados por uma análise de perfil (item por item) o que ajuda a determinar diferenças e semelhanças globais entre os objetos (MALHOTRA, 2001).

Já o diferencial semântico é um meio rápido de examinar os pontos fortes e fracos de um objeto. No entanto, os autores apontam para uma série de desvantagens quanto a sua utilização, como:

a) falta de uma padronização entre as escalas, tendo a técnica de ser adaptada a cada problema de pesquisa;

b) avaliação de um componente específico de imagem pode ser influenciada por uma impressão geral do entrevistado sobre o conceito que está sendo avaliado;

c) divisões das escalas podem ultrapassar a capacidade discriminatória do entrevistado.

Da mesma forma, as escalas de Likert apresentam uma série de itens, geralmente relacionados com as crenças relevantes ao objeto pesquisado, importantes para a formação da atitude (AJZEN, 2002).

Para cada item da escala, são atribuídas cinco categorias de respostas que vão de discordo totalmente a concordo totalmente, e para cada categoria de resposta, é atribuído um valor que pode variar de $-2 \mathrm{a}+2$ ou de 1 a 5 . A cada resposta é atribuído um número que indica a direção da atitude do respondente em relação à afirmação. A pontuação total da atitude (atitude global) é dada pelo somatório das pontuações obtidas em cada afirmação (MATTAR, 2000; MALHOTRA, 2001).

Selltiz et al (apud MATTAR, 2000, p. 104) aponta para as seguintes vantagens apresentadas pela utilização da escala de Likert:

a) permite o emprego de afirmações que não estão explicitamente ligadas à atitude estudada, pode-se incluir qualquer item que se verifique, empiricamente, ser coerente com o resultado total;

b) é de construção mais simples [...];

c) a amplitude das respostas permitidas apresenta informação mais precisa da opinião do respondente em relação a cada afirmação. 
A construção de uma escala Likert envolve a elaboração inicial de um extenso conjunto de afirmações que reflitam qualidades ou características do objeto de estudo que possivelmente influenciem a atitude da pessoa em relação a ele. O refinamento da escala é feito de forma a manter apenas as afirmações com maior capacidade de discriminar entre atitudes favoráveis e desfavoráveis (MALHOTRA, 2001).

Este trabalho utilizou primordialmente a escala de sete pontos, com o objetivo de oferecer uma quantidade maior de opções de resposta para os respondentes. O pré-teste mostrou que a escala era capaz de receber pontuação ao longo de toda sua extensão, e não só nos extremos, sugerindo ter sido compreendida e utilizada pelos respondentes.

Além disso, utilizou-se a amostragem não probabilística. As técnicas não probabilísticas produzem amostras cuja representatividade da população é desconhecida porque não se conhece a probabilidade de um dado elemento da população ser incluído na amostra. Assim, contrariamente ao que ocorre com as amostras probabilísticas, os resultados não podem ser inferidos para a população dentro de margens de confiança e erro estabelecidos.

Mattar (2000) descreve algumas das razões que justificam esse tipo de amostragem:

a) quando a população não está toda disponível para ser sorteada - trata-se de uma pesquisa realizada como parte de um projeto internacional, com o tamanho da amostra predeterminado pelas premissas do projeto. Assim, não havia como realizar as entrevistas com toda a população de consumidores de carne suína brasileira;

b) quando não se quer generalizar os dados obtidos - este estudo tem caráter exploratório, e não tem o objetivo de generalizar os resultados obtidos, mas sim aprofundar os conhecimentos a respeito dos consumidores de carne suína brasileiros. O tipo de amostragem utilizado foi por conveniência, no qual se escolhem os indivíduos que estiverem disponíveis (local, hora) para o entrevistador, de acordo com alguns parâmetros predeterminados, que neste caso foram sexo, idade e domicílio do respondente. 


\subsection{O Pré-teste}

O objetivo do pré-teste é a identificação de problemas, dificuldades de interpretação, eliminação e aperfeiçoamento do conteúdo e do enunciado de cada questão, além da sequência de apresentação, formato e preenchimento (MALHOTRA, 2006).

Assim, foi realizado um pré-teste pela própria pesquisadora, a fim de testar principalmente a facilidade no entendimento das questões e o tempo de realização de cada entrevista, além da familiaridade dos entrevistados quanto aos itens questionados (produtos, sistemas de produção, etc.).

Percebeu-se, então, que o tempo de realização das entrevistas estava muito longo, o que de certa maneira prejudicava a qualidade e mesmo a veracidade das respostas finais. Assim, optou-se por suprimir algumas partes do questionário que se julgavam menos importantes para o consumidor brasileiro (confirmando as discussões realizadas na reunião anual do projeto Q-PorkChains em Monnnels), como a parte de bem-estar animal e as questões de biotecnologia.

Além disso, os produtos foram adaptados ao contexto brasileiro, sendo retirados produtos que não existem no Brasil, como certos cortes frescos, embutidos como alguns tipos de linguiças e pratos prontos. Estes foram então agregados em 11 categorias de produtos que o consumidor vê como um único produto (SICHIERI et al, 2008).

O pré-teste foi realizado em fevereiro de 2008 , concomitantemente ao processo de adaptação do questionário ao Brasil, em um processo circular de revisões, consultas e correções, que envolveu a equipe do projeto no Brasil, a coordenação do Módulo I, na Universidade de Aarhus, e também os profissionais brasileiros da TNS-Interscience.

Já que os dados utilizados neste estudo foram retirados de um projeto maior, o Q-PorkChains, a coleta dos mesmos foi realizada por profissionais da empresa TNS-Interscience, especialmente contratados e treinados para esta pesquisa. Trata-se de uma questão de grande importância, já que os entrevistadores precisam estar bastante familiarizados com o questionário, suas diferentes questões e aspectos específicos. Especialmente neste caso, onde tem-se um questionário bastante extenso, que pode cansar o entrevistado e assim diminuir a qualidade das respostas. $\mathrm{O}$ entrevistador tem que saber responder a quaisquer dúvidas que o entrevistado possa apresentar, tanto em relação ao sentido das perguntas quanto aos tipos de produtos, sistemas de produção, a fim de evitar falhas nos resultados. 


\subsection{Definição da Amostra}

Por determinação do projeto, a fim de possibilitar a comparação entre os países onde a pesquisa foi aplicada, a amostra foi dividida igualmente entre os países participantes, cabendo 480 entrevistas para cada país.

No Brasil, no entanto, essa amostra seria pequena demais caso houvesse interesse em generalizar os resultados. Assim, decidiu-se limitar a realização das entrevistas a apenas algumas cidades que cumprissem certos requisitos, como possuírem criações de suínos nas proximidades, entre outros. Além disso, que possibilitassem encontrar respondentes que atendessem às cotas predeterminadas de gênero, idade, etc.

Os consumidores brasileiros são um grupo heterogêneo. Sendo um país de dimensões continentais $\left(8.514 .876,599 \mathrm{~km}^{2}\right.$, segundo o IBGE), e formado por pessoas descendentes de uma grande variedade de diferentes culturas, pode-se esperar uma significante variabilidade nos comportamentos dos consumidores de alimentos.

Diferenças regionais são fortemente marcantes no contexto de alimentação no Brasil. Pessoas da região nordeste têm hábitos alimentares bastante diferentes das pessoas dos estados do sul. No século XIX, a região sul teve a primeira grande onda de imigrantes vindos da Europa ${ }^{7}$ e muitos dos hábitos alimentares da região foram estabelecidos com base nessas influências.

Além disso, o consumo de carne suína é maior no sul e sudeste em comparação às regiões norte, nordeste e centro-oeste (SCHLINDWEIN; KASSOUF, 2006). O consumo de carne suína nas áreas rurais do Brasil também é maior que nas áreas urbanas, de acordo com o mesmo estudo de Schlindwein e Kassouf (2006). Segundo dados estatísticos brasileiros, $85 \%$ dos domicílios brasileiros situam-se em áreas urbanas e apenas 15\% em áreas rurais (IBGE, 2005).

Estudos anteriores (CARVALHO, 2009; FARIA et al, 2006) indicam que a renda familiar tem efeito altamente positivo e significante na probabilidade de consumo de carne suína no Brasil em nível domiciliar, ou seja, aumento na renda familiar aumenta a probabilidade de consumo de carne suína.

7 http://www.migrationinformation.org/Profiles/display.cfm?ID=311 
Os brasileiros têm boa disponibilidade de carne suína, uma vez que o consumo doméstico representa por volta de $87 \%$ da produção total. O excesso de $13 \%$ é exportado, principalmente para a Rússia e países asiáticos (ABIPECS, 2007).

$\mathrm{Na}$ tentativa de minimizar as importantes diferenças culturais descritas anteriormente, a pesquisa foi aplicada em quatro diferentes estados (Rio Grande do Sul, Paraná, Mato Grosso e Goiás), representando duas regiões diferentes do país, a região sul e o centro-oeste. Além disso, como uma importante parte da pesquisa era verificar a visão do consumidor em relação à produção de suínos, era importante que as cidades selecionadas estivessem em regiões com uma produção relevante desses animais.

Além de a proximidade com a produção aumentar a possibilidade de os consumidores conhecerem algum tipo de produção, também a possibilidade de serem afetados por ela seria maior. Presume-se que o consumidor de grandes centros urbanos como Rio de Janeiro e São Paulo, as maiores cidades do Brasil, estaria menos consciente a respeito da relação entre a produção rural e o consumo de alimentos.

Assim, buscou-se selecionar para a realização das entrevistas cidades que estivessem em regiões que fossem ao mesmo tempo importantes centros consumidores (como as capitais dos estados) e importantes centros de produção de suínos.

Ambas as regiões selecionadas representam sistemas de produção de suínos diferentes, já que a primeira é caracterizada por um tipo de produção bastante tradicional e familiar, com a maior parte de sua população descendente de imigrantes europeus, principalmente da Alemanha, Itália e Holanda.

Por outro lado, a região centro-oeste representa uma nova área de produção. Altamente industrial, com propriedades maiores, mais profissionalizadas e que utilizam mais tecnologias, essa região foi responsável por um crescimento de 176\% na produção de suínos de 1998 a 2004 (MIELE; GIROTTO, 2006). A região ainda está crescendo, já que está localizada no centro da área brasileira de produção de grãos. Isto faz bastante diferença em termos de custos de produção (MIELE, 2007; SILVEIRA; TALAMINI, 2007; MIELE; GIROTTO, 2008).

Essa região é bastante diferente, menos populosa, mas com crescimento rápido, uma vez que novas cidades vêm sendo criadas à medida que a indústria segue a expansão da produção agrícola e pecuária (bovinos, suínos e frangos). Pessoas têm migrado de outros estados para a região centro-oeste, resultando em uma larga variedade de culturas e hábitos. 
Assim, dados descritivos quantitativos foram coletados por meio de uma pesquisa de mercado em oito cidades brasileiras selecionadas nos quatro estados escolhidos, dois deles representando o sistema tradicional de produção de suínos (Rio Grande do Sul e Paraná) e dois outros das novas áreas produtoras (Mato Grosso e Goiás). O critério estabelecido para selecionar as cidades foi o de que para cada um dos estados ter-se-ia (1) uma cidade grande, a capital do estado, e também (2) uma cidade pequena com nível de produção de médio a alto. Por essa razão:

- Curitiba e Ponta Grossa foram selecionadas no estado do Paraná;

- Porto Alegre e Santa Rosa, no estado do Rio Grande do Sul;

- Cuiabá e Campo Verde, no estado do Mato Grosso;

- Goiânia e Rio Verde, no estado de Goiás. 


\section{RESULTADOS: APRESENTAÇÃO E ANÁLISE DOS DADOS}

\subsection{Caracterização da Amostra}

Os participantes foram selecionados por conveniência, por profissionais da empresa de pesquisa TNS-Interscience de acordo com cotas predeterminadas em relação a idade e região. A aplicação do questionário foi feita por meio de entrevistas pessoais, que tiveram duração entre 45 e 60 minutos.

A população-alvo foi dividida intencionalmente em três grupos diferentes (de 18 a 30 anos, de 31 a 50, e com mais de 50 anos), com cotas específicas de acordo com a idade e local de residência (igualmente divididas entre as oito cidades). Um número total de 482 pessoas respondeu à entrevista. As mulheres representaram 50,2\% da amostra total e os homens, 49,8\%.

A maior parte dos respondentes situava-se na faixa entre 35 e 55 anos $(39,6 \%$ dos homens e $43,8 \%$ das mulheres), seguidos por pessoas com menos de 35 anos (38,8\% dos homens e $38,4 \%$ das mulheres), a menor participação no total da amostra foi de pessoas com mais de 55 anos (21,7\% dos homens e 17,8\% das mulheres), de acordo com a Tabela 1.

Tabela 1 - Distribuição da amostra por idade e por gênero

\begin{tabular}{cccccc}
\hline Distribuição da amostra por idade e por gênero & \multicolumn{2}{c}{ Homens } & \multicolumn{2}{c}{ Mulheres } \\
& $\mathrm{N}$ & $\%$ & $\mathrm{~N}$ & $\%$ \\
\hline Menos de 35 anos & 93 & 38,8 & 93 & 38,4 \\
& & & & \\
\hline & 95 & 39,6 & 106 & 43,8 \\
Mais de 55 anos 55 anos & 52 & 21,7 & 43 & 17,8 \\
Total & 240 & 49,8 & 242 & 50,2 \\
\hline
\end{tabular}

De acordo com a cota predeterminada, 50\% dos respondentes vivem em áreas urbanas e 50\% em cidades pequenas com alta densidade de produção de suínos. A distribuição dos respondentes entre as cidades, por idade e gênero, está descrita na Tabela 2: 
Tabela 2 - Distribuição da amostra por idade, gênero e cidade

\begin{tabular}{lcccccccc}
\hline & \multicolumn{2}{c}{ Rio Grande do Sul } & \multicolumn{2}{c}{ Paraná } & \multicolumn{2}{c}{ Mato Grosso } & \multicolumn{2}{c}{ Goiás } \\
\hline Perfil & Porto & Santa & Curitiba & Ponta & Cuiabá & Campo & Goiânia & Rio \\
& Alegre & Rosa & & Grossa & & Verde & & Verde \\
\hline Masculino & 30 & 31 & 30 & 30 & 30 & 29 & 30 & 30 \\
Feminino & 30 & 31 & 30 & 30 & 30 & 31 & 30 & 30 \\
Total & 30 & 62 & 60 & 60 & 60 & 60 & 60 & 60 \\
\hline $18-30$ & 18 & 19 & 20 & 20 & 19 & 20 & 21 & 20 \\
$31-50$ & 23 & 24 & 21 & 21 & 23 & 20 & 21 & 20 \\
$51-65$ & 19 & 19 & 19 & 19 & 18 & 20 & 18 & 20 \\
Total & 60 & 62 & 60 & 60 & 60 & 60 & 60 & 60 \\
\hline
\end{tabular}

Como as questões envolviam certo conhecimento sobre a produção de suínos, perguntou-se ao entrevistado se conhecia algum produtor. O resultado está apresentado na Tabela 3, a seguir.

Tabela 3 - Quantidade de respondentes que conhecem produtores de suínos

\section{Conhece algum produtor de suínos?}

\begin{tabular}{ccc}
\hline Sim & 117 & $24,3 \%$ \\
Não & 355 & $73,7 \%$ \\
Não sei & 10 & $2,1 \%$ \\
\hline Total & $\mathbf{4 8 2}$ & $\mathbf{1 0 0 , 0 \%}$ \\
\hline
\end{tabular}

Também se questionou sobre o local ou a proximidade de residência do respondente em relação a alguma criação de suínos, o que está demonstrado na Tabela 4. 
Tabela 4 - Quantidade de respondentes que moram perto de alguma criação de suínos

\begin{tabular}{|ccc}
\hline & Mora perto de alguma criação de suínos? & $6,4 \%$ \\
\hline Sim & 31 & $91,9 \%$ \\
Não & 439 & $2,5 \%$ \\
\hline Não sei & 12 & $\mathbf{1 0 0 , 0 \%}$ \\
\hline Total & $\mathbf{4 8 2}$ & \\
\hline
\end{tabular}

A totalidade dos respondentes afirmou serem consumidores de carne suína.

Setenta e cinco por cento dos respondentes não vivem sozinhos (50\% casados, $25 \%$ não casados, mas vivendo com um parceiro), enquanto o restante dos respondentes inclui solteiros (10\%), viúvos $(6 \%)$ ou divorciados (9\%). A maioria dos respondentes tem ensino médio (44,5\%), seguido por ensino fundamental completo $(29,1 \%), 14,9 \%$ possuem ensino fundamental incompleto, e apenas $11,6 \%$ cursaram faculdade e estudos posteriores (pós-graduação, mestrado, Doutorado, etc.).

Tabela 5 - Distribuição da amostra por situação familiar e nível de escolaridade

\begin{tabular}{cc}
\hline Distribuição da amostra por situação familiar e nível de & Amostra n=482 \\
escolaridade & $\%$ \\
\hline Situação familiar & 50 \\
Casado & 25 \\
Vive com parceiro & 10 \\
Solteiro & 6 \\
Viúvo & 9 \\
Divorciado & 14,5 \\
Nível de escolaridade & 29,1 \\
Ensino fundamental incompleto & 44,5 \\
Ensino fundamental completo & 11,6 \\
Ensino médio completo & \\
Faculdade e além & \\
\hline
\end{tabular}


Dividindo-se a amostra por estado, percebe-se que foi igualmente distribuída entre os quatro estados (24,9\% em cada, com exceção do Rio Grande do Sul, com 25,3\%). O grau de educação não teve variação expressiva entre os diferentes estados e a ordenação foi a mesma para todos. A exceção foi o estado de Goiás, onde a amostra continha mais respondentes com educação superior (faculdade e pós-graduação) do que ensino fundamental incompleto. 
Tabela 6 - Características sociodemográficas dos respondentes da amostra por estado

\begin{tabular}{|c|c|c|c|c|c|c|c|c|}
\hline & $\begin{array}{c}\text { Rio } \\
\text { Grande do } \\
\text { Sul }\end{array}$ & & Paraná & & $\begin{array}{c}\text { Mato } \\
\text { Grosso }\end{array}$ & & Goiás & \\
\hline & $\mathrm{N}$ & $\%$ & $\mathrm{~N}$ & $\%$ & $\mathrm{~N}$ & $\%$ & $\mathrm{~N}$ & $\%$ \\
\hline \multicolumn{9}{|l|}{ Gênero do respondente } \\
\hline Homens & 61 & 50,0 & 60 & 50,0 & 59 & 49,2 & 60 & 50,0 \\
\hline Mulheres & 61 & 50,0 & 60 & 50,0 & 61 & 50,8 & 60 & 50,0 \\
\hline \multicolumn{9}{|l|}{ Localidade } \\
\hline Urbano & 60 & 50,8 & 60 & 50,0 & 61 & 50,8 & 60 & 50,0 \\
\hline Não urbano & 62 & 49,2 & 60 & 50,0 & 59 & 49,2 & 60 & 50,0 \\
\hline \multicolumn{9}{|l|}{ Nível de escolaridade } \\
\hline Ensino fundamental incompleto & 24 & 19,7 & 20 & 16,7 & 20 & 16,7 & 13 & 10,8 \\
\hline Ensino fundamental completo & 38 & 31,1 & 32 & 26,7 & 35 & 29,2 & 34 & 28,3 \\
\hline Ensino médio completo & 49 & 40,2 & 56 & 46,7 & 49 & 40,8 & 58 & 48,3 \\
\hline Faculdade e além & 11 & 9,0 & 12 & 10,0 & 16 & 13,3 & 15 & 12,5 \\
\hline \multicolumn{9}{|l|}{ Situação financeira da família } \\
\hline Bem de vida A1 & 0 & 0,0 & 0 & 0,0 & 0 & 0,0 & 1 & 0,8 \\
\hline Bem de vida A2 & 12 & 9,8 & 11 & 9,2 & 12 & 10,0 & 11 & 9,2 \\
\hline
\end{tabular}




\begin{tabular}{|c|c|c|c|c|c|c|c|c|}
\hline Razoável B1 & 11 & 9,0 & 13 & 10,8 & 11 & 9,2 & 12 & 10,0 \\
\hline Modesto B2 & 29 & 23,8 & 24 & 20,0 & 28 & 23,3 & 24 & 20,0 \\
\hline Difícil C1 & 42 & 34,4 & 42 & 35,0 & 38 & 31,7 & 48 & 40,0 \\
\hline Ruim C2 & 28 & 23,0 & 30 & 25,0 & 31 & 25,8 & 24 & 20,0 \\
\hline \multicolumn{9}{|l|}{ Ocupação atual } \\
\hline Produtor rural autônomo ou integrado & 1 & 0,8 & 0 & 0,0 & 6 & 5,0 & 2 & 1,7 \\
\hline Autônomo em geral & 39 & 32,0 & 27 & 22,5 & 26 & 21,7 & 28 & 23,3 \\
\hline Supervisor/gerente & 2 & 1,6 & 0 & 0,0 & 1 & 0,8 & 1 & 0,8 \\
\hline Trabalhador assalariado & 26 & 21,3 & 41 & 34,2 & 20 & 16,7 & 28 & 23,3 \\
\hline Trabalhador qualificado & 9 & 7,4 & 8 & 6,7 & 17 & 14,2 & 16 & 13,3 \\
\hline Trabalhador não qualificado & 3 & 2,5 & 2 & 1,7 & 4 & 3,3 & 0 & 0 \\
\hline Estudante & 5 & 4,1 & 8 & 6,7 & 7 & 5,8 & 9 & 7,5 \\
\hline Aposentado & 15 & 12,3 & 7 & 5,8 & 16 & 13,3 & 12 & 10,0 \\
\hline Desempregado ou em transição & 3 & 2,5 & 4 & 3,3 & 2 & 1,7 & 16 & 13,3 \\
\hline Não trabalha & 12 & 9,8 & 20 & 16,7 & 10 & 8,3 & 6 & 5,0 \\
\hline Outros & 7 & 5,7 & 3 & 2,5 & 11 & 9,2 & 2 & 1,7 \\
\hline
\end{tabular}


A situação financeira é difícil (C1) para a maioria da amostra (31 a 40\%), seguida por ruim (C2, por volta de 25\%) e modesta (B2, por volta de 24\%). A maior parte da amostra (11\%) é considerada bem de vida e dentro dessa classificação apenas $0,8 \%$ da amostra corresponde à elite (bem de vida A1) em Goiás.

Em todos os estados, a maior parte da amostra é composta de trabalhadores autônomos em geral e trabalhadores assalariados, em termos de ocupação atual. As amostras no Mato Grosso e em Goiás têm mais produtores rurais autônomos e trabalhadores qualificados que as amostras do Rio Grande do Sul e Paraná. Goiás, por sua vez, apresenta a mais alta taxa de desempregados entre os estados.

A maioria dos respondentes reportou ter peso normal (56,6\% das mulheres e 46,3\% dos homens). Grande parte dos homens (41,3\%) está acima do peso e 12,2\% são obesos. Apenas $0,4 \%$ está abaixo do peso. Entre as mulheres, $5 \%$ estão abaixo do peso, $26 \%$ acima e $12,4 \%$ são obesas (Tabela 7).

Tabela 7 - Situação nutricional da amostra por gênero

\begin{tabular}{ccccc}
\hline $\begin{array}{c}\text { Situação } \\
\text { Nutricional }\end{array}$ & \multicolumn{2}{c}{ Mulheres } & \multicolumn{2}{c}{ Homens } \\
& $\mathrm{N}$ & $\%$ & $\mathrm{~N}$ & $\%$ \\
\hline Normal & 137 & 56,6 & 111 & 46,3 \\
Baixo peso & 12 & 5,0 & 1 & 0,4 \\
Sobrepeso & 63 & 26,0 & 99 & 41,3 \\
Obeso & 30 & 12,4 & 29 & 12,1 \\
\hline
\end{tabular}

Entre os estados, os resultados indicam que a maior parte dos respondentes tem peso normal (especialmente no Rio Grande do Sul e Paraná, com mais de 50\%) seguida por quase $40 \%$ acima do peso. De 6,6 a 15,8\% da amostra é obesa (Mato Grosso e Goiás com 15\% ou mais) e apenas de 2,5 a 3,3\% da amostra está abaixo do peso. Tais resultados são preocupantes se for considerado o nível agregado de sobrepeso e obesidade dos respondentes. Neste caso, Mato Grosso tem mais de $50 \%$ da amostra como acima do peso e obesos. 
Tabela 8 - Situação nutricional da amostra por estado

\section{Rio}

Grande do

Sul

$$
\mathrm{N}
$$

$\mathrm{N} \quad \%$

Status Nutricional

\begin{tabular}{cccccccccc} 
Peso normal & 73 & 59,8 & 64 & 53,3 & 51 & 42,5 & 60 & 50,0 \\
Baixo peso & 3 & 2,5 & 3 & 2,5 & 3 & 2,5 & 4 & 3,3 \\
Sobrepeso & 38 & 31,1 & 39 & 32,5 & 47 & 39,2 & 38 & 31,7 \\
Obeso & 8 & 6,6 & 14 & 11,7 & 19 & 15,8 & 18 & 15,0 \\
\hline
\end{tabular}

O Gráfico 1 uma melhor visualização desses resultados, distribuídos por cidade. Considerando somente obesos e não obesos, percebe-se que nenhuma cidade apresenta níveis preocupantes em termos de peso. 


\section{Bar Chart}

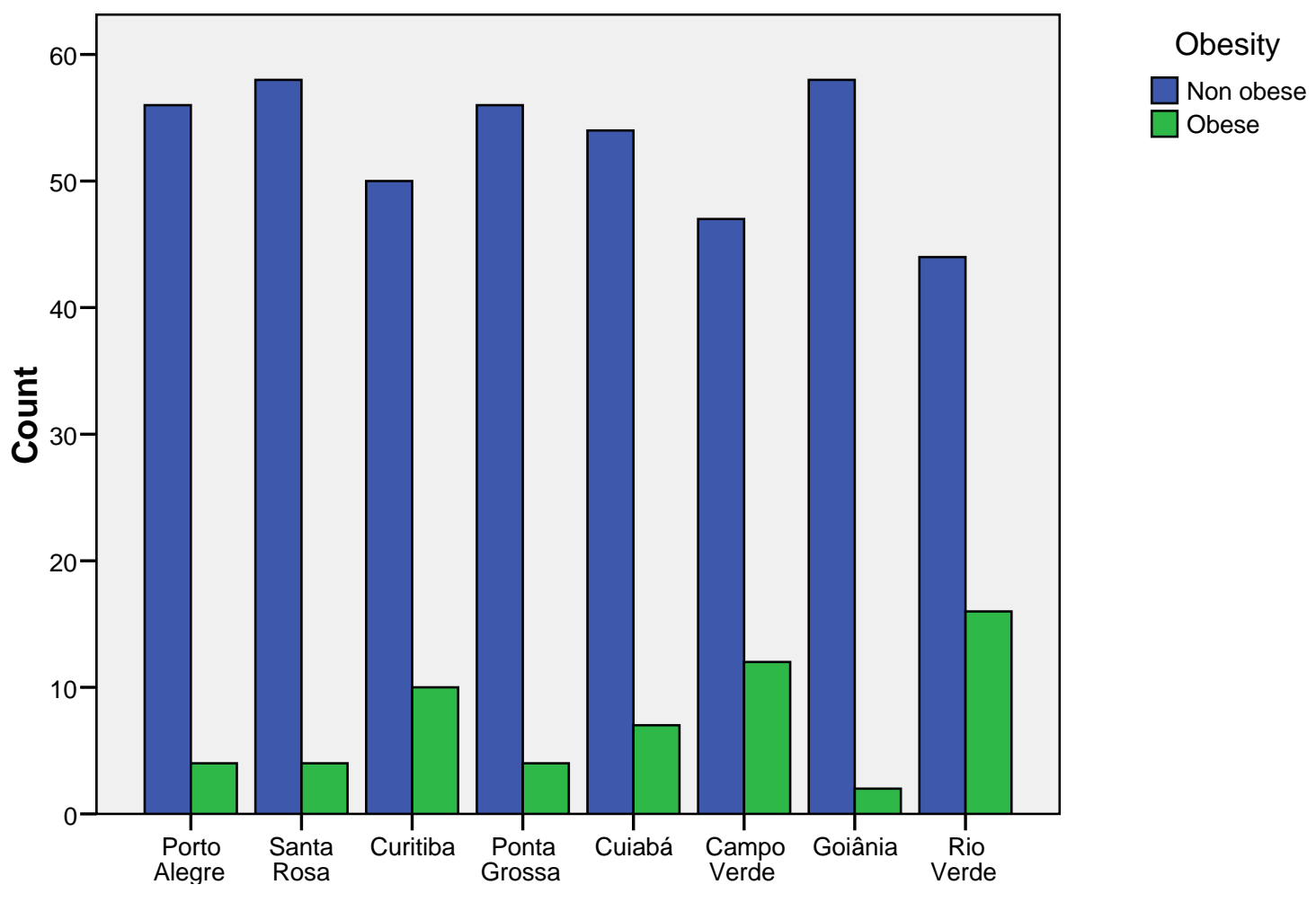

Gráfico 1 - Situação nutricional da amostra por cidade

Com relação à massa corporal, a média das mulheres apresentou índice de massa corporal (IMC) de $24,5 \mathrm{~kg} / \mathrm{m}^{2}$, e os homens, $25,7 \mathrm{~kg} / \mathrm{m}^{2}$, o que resultou em uma média de $25,1 \mathrm{~kg} / \mathrm{m}^{2}$. A Tabela 9 demonstra esses valores e também o peso e a altura autorreportados dos respondentes. A média de peso entre as mulheres foi de $64,3 \mathrm{~kg}$ e de homens, $77 \mathrm{~kg}$. A altura média das mulheres era de $1,62 \mathrm{~m}$ e entre os homens, de 1,73m, perfazendo uma média geral de $1,68 \mathrm{~m}$. 
Tabela 9 - Medidas antropométricas e IMC por gênero

\begin{tabular}{cccccccccc}
\hline & Mulheres & \multicolumn{3}{c}{ Homens } & \multicolumn{5}{c}{ Total } \\
& Média & DP & N & Média & DP & N & Média & DP & N \\
& & & & & & & & & \\
\hline $\begin{array}{c}\text { Índice de Massa Corporal } \\
\left(\mathrm{kg} / \mathrm{m}^{2}\right)\end{array}$ & 24,5 & 4,5 & 242 & 25,7 & 3,9 & 240 & 25,1 & 4,2 & 482 \\
Peso $(\mathrm{kg})$ & 64,3 & 11,7 & 242 & 77,0 & 12,1 & 240 & 70,6 & 13,5 & 482 \\
Altura $(\mathrm{cm})$ & 162 & 7,5 & 242 & 173 & 6,8 & 240 & 168 & 9,0 & 482 \\
\hline
\end{tabular}

Algumas observações feitas pelo pessoal que aplicou a pesquisa merecem atenção:

- na cidade de Campo Verde (MT), a imagem da suinocultura e da carne suína é ruim, pois existe lá um criador que vende carne sem inspeção pelos órgãos do Ministério da Agricultura;

- em especial em Goiânia e Rio Verde foram notadas dificuldades em relação à extensão do questionário, considerado muito extenso e pouco objetivo. Os respondentes afirmavam estar cansados e confusos;

- nas cidades de Curitiba e Ponta Grossa, cidades de população predominantemente católica e alemã, as pessoas têm o hábito de comer alimentos à base de carne suína, e não se ouve falar em doenças;

- alguns respondentes relataram comer alimentos feitos à base de carne suína sem saber do que eram feitos, como presunto, mortadela e bacon.

\subsection{Tratamento dos Dados}

Antes de analisar quaisquer tipos de dados utilizando técnicas estatísticas multivariadas, deve-se primeiramente proceder a um tratamento desses dados, a fim de aumentar sua capacidade de previsão (HAIR JR. et al, 2006). A seguir estão descritos os tratamentos preliminares realizados nesta pesquisa. 


\subsubsection{Dados omissos}

Os dados omissos (missing values) são dados faltantes na base de dados. Essa ocorrência pode ter diversas causas, entre elas erros na digitação da base de dados, falha do pesquisador na aplicação do questionário, recusa do respondente em responder a determinada questão, entre outras, devendo, para ser passível de tratamento, não ultrapassar o nível de $10 \%$ dos itens (KLINE, 2005).

Neste estudo foi utilizada a técnica de missing values proposta por Kline (2005): o método de expectation maximization (maximização da expectação), que estima os dados omissos por máxima verossimilhança (maximum likelihood) por meio de um processo interativo (HOPPE, 2010); não houve dados faltantes, de forma a se obterem 482 casos válidos para a análise.

\subsubsection{Outliers}

Outliers são casos extremos ou observações numericamente distantes do resto do dados. Neste trabalho, os outliers foram verificados por meio da distância de Mahalanobis (medida de distância baseada nas correlações entre variáveis com as quais distintos padrões podem ser identificados e analisados). Considerando-se o nível de significância de 0,1\%, indicado por Kline (2005), não se verificaram outliers nos dados.

Por tratar-se de uma base de dados bastante heterogêneos entre si, uma vez que o questionário é composto de várias seções com diferentes escalas e instrumentos de pesquisa, optou-se por realizar os tratamentos posteriores de acordo com cada grupo de dados. 


\subsection{Resultados Obtidos}

A seguir serão apresentados os resultados obtidos com a realização da pesquisa.

\subsubsection{Estilo de vida}

A primeira parte do questionário, logo após as questões iniciais de caracterização da amostra, continha questões sobre o estilo de vida dos consumidores de carne suína no Brasil. O instrumento utilizado foi o $F R L$, descrito na seção 2.5 deste trabalho. O questionário completo, incluindo as questões sobre estilo de vida, está descrito no Apêndice A.

A Tabela 10 mostra as médias e desvios padrão das dimensões do $F R L$, bem como a confiabilidade do instrumento utilizado na pesquisa, calculada pelo teste alfa de Cronbach, medida de consistência interna baseada na média da correlação entre os itens que compõem uma escala. De acordo com Hair Jr. et al (2006), um resultado desejável para essa medida é próximo de 1 , sendo aceitáveis os que fiquem acima de 0,60.

Entretanto, alguns autores impõem outros limites, como 0,5 (GEORGE, 2003). De maneira geral, considerando as 23 dimensões investigadas da escala, os valores do alfa de Cronbach variaram entre 0,031 e 0,810, o que indica confiabilidade considerada de moderada (alfa de Cronbach >_0,5) a satisfatória (alfa de Cronbach >_ 0,7). Neste caso, deve-se levar em consideração que a confiabilidade dos instrumentos designados para aplicações em diferentes culturas é mais baixa por causa da variação remanescente entre culturas. 


\begin{tabular}{|c|c|c|c|}
\hline Dimensões do $F R L$ & Média & $\begin{array}{l}\text { Desvio } \\
\text { Padrão }\end{array}$ & Alfa de Cronbach \\
\hline Saúde & 5,09 & 1,10 & 0,479 \\
\hline Relação preço/qualidade* & 5,91 & 0,98 & 0,520 \\
\hline Novidade & 3,95 & 0,98 & 0,365 \\
\hline Produtos orgânicos** & 4,25 & 1,43 & 0,712 \\
\hline Sabor & 5,10 & 0,94 & 0,168 \\
\hline Frescor & 5,37 & 1,08 & 0,432 \\
\hline Autorrealização com a comida & 5,03 & 1,19 & 0,424 \\
\hline Segurança & 5,58 & 0,98 & 0,336 \\
\hline Relacionamentos sociais & 5,13 & 0,96 & 0,149 \\
\hline Interesse pela culinária & 4,25 & 0,92 & 0,241 \\
\hline Busca de novas maneiras (inovação)* & 4,69 & 1,27 & 0,568 \\
\hline Conveniência* & 3,72 & 1,55 & 0,662 \\
\hline Envolvimento de toda a família & 4,83 & 1,34 & 0,434 \\
\hline Planejamento* & 3,82 & 1,31 & 0,519 \\
\hline Tarefa feminina* & 4,17 & 1,47 & 0,616 \\
\hline $\begin{array}{l}\text { Importância de informação sobre o } \\
\text { produto }\end{array}$ & 5,28 & 1,07 & 0,367 \\
\hline Atitudes em relação a propaganda & 4,66 & 1,20 & 0,413 \\
\hline Prazer de comprar & 4,51 & 1,12 & 0,031 \\
\hline Lojas especializadas** & 3,78 & 1,55 & 0,714 \\
\hline Critério de preços & 5,43 & 1,11 & 0,462 \\
\hline Lista de compras** & 4,56 & 1,82 & 0,810 \\
\hline Lanches $v s$. refeições* & 4,11 & 1,36 & 0,584 \\
\hline Evento social** & 4,59 & 1,43 & 0,700 \\
\hline
\end{tabular}

Notas: *Confiabilidade moderada

**Confiabilidade satisfatória

Os resultados indicam que para os entrevistados, os fatores 'relação preço-qualidade', 'segurança', e 'critério de preços' são os mais importantes, sinalizando que são conscientes em relação a preços e tradicionais em sua maneira de se alimentarem. 'Frescor', 'importância de informações sobre o produto', 'relacionamentos sociais', 'sabor' e 'saúde' também são importantes. 
Quanto à confiabilidade da escala, percebe-se que apenas quatro de suas dimensões possuem índices que podem ser considerados satisfatórios: 'produtos orgânicos', 'lojas especializadas', 'lista de compras' e 'evento social'. Considerando-se as dimensões com alfa acima de 0,5, que se chamou de confiabilidade moderada, tem-se mais 6: 'relação preço/qualidade', 'busca de novas maneiras (inovação)', 'conveniência', 'planejamento', 'tarefa feminina' e 'lanches versus refeições'.

\subsubsection{Valores e atitudes}

\subsubsection{Análise fatorial exploratória}

Optou-se por realizar apenas uma análise exploratória para analisar os valores e atitudes, verificando-se, assim, quais eram os mais importantes para a amostra entrevistada. Essa análise obteve índice de KMO (Keiser-Meyer-Olkin) de 0,761. O índice de KMO é uma medida de adequação da amostra, que testa se as correlações parciais entre as variáveis em análise são pequenas (HAIR JR. et al, 2006).

Realizou-se então, o teste de esfericidade de Bartlett, que, segundo Hair Jr. et al (2006), verifica se a matriz de correlação é uma matriz de identidade, o que indicaria que o modelo fatorial é inapropriado. Neste caso, o teste rejeita a hipótese nula, ou seja, as correlações entre as variáveis são suficientemente fortes para que a análise fatorial possa ser aplicada. As medidas de adequação das variáveis individuais são adequadas, assim como as comunalidades são satisfatórias.

A rotação varimax é um método de rotação ortogonal que minimiza o número de variáveis com cargas altas em cada fator, facilitando a interpretação dos resultados (HAIR JR. et al, 2006). Aqui, aplicou-se a análise dos componentes principais com rotação varimax, obtendo-se oito fatores com eigenvalue (autovalor) maior que um, que explicam 62,602\% da variância dos dados.

Os fatores analisados possuem confiabilidade satisfatória, mensurada pelo índice Alfa de Cronbach. Neste caso, no entanto, optou-se por eliminar apenas os que ficavam abaixo de 0,50. 
O Quadro 8 apresenta a análise fatorial e os fatores com suas dimensões. A carga fatorial representa quanto o item é importante para a amostra estudada. Na última linha do quadro estão apresentados os coeficientes Alfa de Cronbach obtidos para cada fator. 
Quadro 8 - Análise fatorial dos valores e atitudes da pesquisa e suas dimensões

\begin{tabular}{|c|c|c|c|c|c|c|c|c|}
\hline & $\begin{array}{l}\text { Fator } 1- \\
\text { Etnocentris } \\
\text { mo }\end{array}$ & $\begin{array}{l}\text { Fator 2 - } \\
\text { Atitudes em } \\
\text { relação a } \\
\text { como a } \\
\text { produção de } \\
\text { alimentos } \\
\text { afeta o meio } \\
\text { ambiente }\end{array}$ & $\begin{array}{l}\text { Fator 3 - } \\
\text { Atitudes em } \\
\text { relação à } \\
\text { produção } \\
\text { industrial de } \\
\text { alimentos }\end{array}$ & $\begin{array}{l}\text { Fator } 4- \\
\text { Valores }- \\
\text { Conformida } \\
\text { de, Poder e } \\
\text { Segurança }\end{array}$ & $\begin{array}{l}\text { Fator 5 - } \\
\text { Valores }- \\
\text { Estímulo, } \\
\text { Realização e } \\
\text { Hedonismo }\end{array}$ & $\begin{array}{l}\text { Fator 6 - } \\
\text { Atitudes em } \\
\text { relação ao } \\
\text { meio } \\
\text { ambiente e à } \\
\text { natureza }\end{array}$ & $\begin{array}{l}\text { Fator } 7- \\
\text { Valores - } \\
\text { Universalis } \\
\text { mo e } \\
\text { Benevolênci } \\
\text { a }\end{array}$ & $\begin{array}{l}\text { Fator } 8- \\
\text { Atitudes em } \\
\text { relação aos } \\
\text { avanços } \\
\text { tecnológicos }\end{array}$ \\
\hline $\begin{array}{l}\text { q4_5 - Um brasileiro de verdade } \\
\text { deve comprar sempre produtos } \\
\text { feitos no Brasil }\end{array}$ & 0,797 & & & & & & & \\
\hline $\begin{array}{l}\text { q4_6 - Devemos comprar produtos } \\
\text { feitos no Brasil ao invés de deixar } \\
\text { outros países ficarem ricos às } \\
\text { nossas custas }\end{array}$ & 0,794 & & & & & & & \\
\hline $\begin{array}{l}\text { q4_4 - Produtos brasileiros acima } \\
\text { de tudo }\end{array}$ & 0,785 & & & & & & & \\
\hline $\begin{array}{l}\text { q4_8 - Isso pode me custar a longo } \\
\text { prazo, mas prefiro apoiar produtos } \\
\text { brasileiros }\end{array}$ & 0,726 & & & & & & & \\
\hline $\begin{array}{l}\mathrm{q} 4 \text { 4_7 - É sempre melhor comprar } \\
\text { produtos brasileiros }\end{array}$ & 0,634 & & & & & & & \\
\hline \begin{tabular}{lcc} 
q4_3 - & Comprar & \multicolumn{2}{c}{ produtos } \\
produzidos no Brasil ajuda no \\
sustento de comunidades locais
\end{tabular} & 0,618 & & & & & & & \\
\hline $\begin{array}{l}\text { q4_2 - Consumidores brasileiros } \\
\text { que compram produtos feitos em } \\
\text { outros países são responsáveis por } \\
\text { deixarem colegas brasileiros sem } \\
\text { emprego }\end{array}$ & 0,589 & & & & & & & \\
\hline $\begin{array}{l}\text { q5_1 - É importante que a comida } \\
\text { que eu como normalmente...seja } \\
\text { preparada de modo que não } \\
\text { prejudique o meio ambiente. }\end{array}$ & & 0,878 & & & & & & \\
\hline $\begin{array}{l}\text { q5_2 - É importante que a comida } \\
\text { que eu como normalmente... seja } \\
\text { produzida de modo que não } \\
\text { interfira no equilíbrio da natureza. }\end{array}$ & & 0,842 & & & & & & \\
\hline q5_3- É importante que a comida & & 0,798 & & & & & & \\
\hline
\end{tabular}




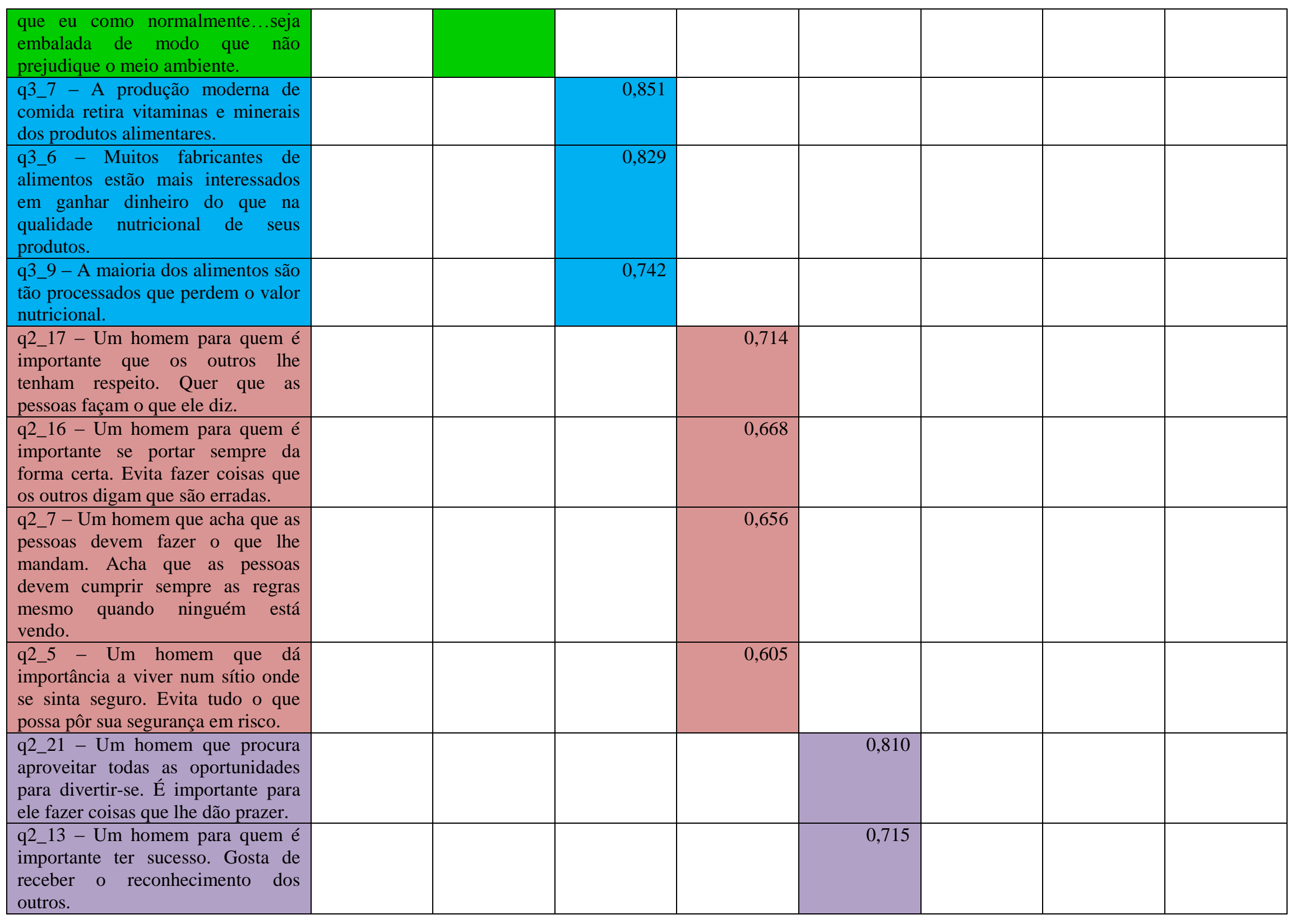




\begin{tabular}{|c|c|c|c|c|c|c|c|c|}
\hline $\begin{array}{l}\text { q2_15 - Um homem que procura } \\
\text { aventura e gosta de correr riscos. } \\
\text { Quer ter uma vida emocionante. }\end{array}$ & & & & & 0,599 & & & \\
\hline $\begin{array}{l}\text { q2_6 - Um homem que gosta de } \\
\text { surpresas e está sempre à procura } \\
\text { de coisas novas para fazer. Acha } \\
\text { que é importante fazer muitas } \\
\text { coisas diferentes na vida. }\end{array}$ & & & & & 0,582 & & & \\
\hline $\begin{array}{l}\text { q3_2 - O equilíbrio da natureza é } \\
\text { forte o bastante para aguentar os } \\
\text { impactos das nações } \\
\text { industrializadas modernas. }\end{array}$ & & & & & & 0,806 & & \\
\hline $\begin{array}{l}\text { q3_3 - A chamada "crise } \\
\text { ecológica" diante da humanidade } \\
\text { tem sido muito exagerada. }\end{array}$ & & & & & & 0,734 & & \\
\hline $\begin{array}{l}\text { q3_1 - Os humanos estão abusando } \\
\text { muito do meio ambiente. }\end{array}$ & & & & & & 0,521 & & \\
\hline $\begin{array}{l}\text { q2_3-Um homem que acha } \\
\text { importante que todas as pessoas no } \\
\text { mundo sejam tratadas igualmente. } \\
\text { Acredita que todos devem ter as } \\
\text { mesmas oportunidades na vida. }\end{array}$ & & & & & & & 0,727 & \\
\hline $\begin{array}{l}\text { q2_12 - Um homem para quem é } \\
\text { importante ajudar os que o rodeiam. } \\
\text { Gosta de zelar pelo seu bem-estar. }\end{array}$ & & & & & & & 0,690 & \\
\hline $\begin{array}{l}\text { q3_14 - Através dos tempos, o } \\
\text { conhecimento tecnológico tem sido } \\
\text { a arma mais importante na luta pela } \\
\text { vida. }\end{array}$ & & & & & & & & 0,701 \\
\hline $\begin{array}{l}\text { q3_13- No Brasil, estamos } \\
\text { provavelmente melhores que nunca, } \\
\text { graças aos grandes avanços da } \\
\text { tecnologia. }\end{array}$ & & & & & & & & 0,540 \\
\hline Alfa de Cronbach & $1(0,843)$ & $2(0,811)$ & $3(0,773)$ & $4(0,651)$ & $5(0,667)$ & $6(0,624)$ & $7 *$ & $8 *$ \\
\hline
\end{tabular}

Notas: Método de Extração: Análise de Componente Principal.

Método de Rotação: Varimax com Normalização Kaiser.

a. Rotação convergiu em 7 interações.

* Para os fatores que possuem apenas dois itens, não se recomenda calcular o alfa de Cronbach.. 
Os resultados demonstram que nem todas as escalas se confirmaram na pesquisa realizada aqui no Brasil, segundo as escalas originais. Assim, essas foram excluídas da análise.

No fator 'Etnocentrismo', por exemplo, a dimensão representada pela questão 1 (“Compre produtos feitos no Brasil. Mantenha o país funcionando.") teve de ser retirada por apresentar um índice de confiabilidade muito baixo.

Já o fator 'Atitudes em relação a como a produção de alimentos afeta o meio ambiente'mantevese totalmente, com valores superiores aos demais. Isso indica que tal atitude é importante para a amostra entrevistada.

No fator 'Atitudes em relação à produção industrial de alimentos', apesar de os resultados demonstrarem valores altos, uma dimensão foi retirada ('A indústria alimentícia está muito preocupada com o valor nutricional de seus produtos'). As outras três dimensões foram mantidas.

Os valores 'Conformidade', 'Poder' e 'Segurança' foram agrupados em um único item, e mantiveram-se as duas dimensões do valor 'Conformidade', porém retiraram-se uma dimensão do valor 'Poder' ('Um homem para quem é importante ser rico. Quer ter muito dinheiro e coisas caras.') e uma dimensão do valor 'Segurança' ('Um homem para quem é importante que o Governo garanta sua segurança, contra todas as ameaças. Quer que o Estado seja forte, de modo a defender os cidadãos.').

Os valores 'Estímulo', 'Realização’ e 'Hedonismo' foram também agrupados, porém somente se manteve com os dois itens da escala original o valor 'Estímulo', tendo ficado fora da análise os itens 'Um homem para quem é importante passar bons momentos. Gosta de tratar bem de si mesmo', do valor 'Hedonismo', e 'Um homem que dá muita importância a poder mostrar as suas capacidades. Quer que as pessoas admirem o que faz'.

No fator 'Atitudes em relação ao meio ambiente e à natureza', composto inicialmente de cinco itens, apenas três foram mantidos na análise, com relação à escala inicial, tendo sido retirados os itens 'A Terra é como uma espaçonave com pouco espaço e recursos limitados' e 'Se as coisas continuarem como estão, logo teremos uma grande catástrofe ecológica', porém a dimensão 1 ('Os humanos estão abusando muito do meio ambiente') obteve um valor bastante baixo (0,521), indicando pouca importância para a amostra pesquisada. 
Os valores 'Universalismo' e 'Benevolência' foram agrupados em um único fator, porém foi mantida apenas uma dimensão de cada um: 'Um homem que acha importante que todas as pessoas no mundo sejam tratadas igualmente. Acredita que todos devem ter as mesmas oportunidades na vida', do valor 'Universalismo', e 'Um homem para quem é importante ajudar os que o rodeiam. Gosta de zelar pelo seu bem-estar', do valor 'Benevolência'. Trata-se, portanto, de valores considerados menos importantes dentro da amostra entrevistada.

Nas 'Atitudes em relação aos avanços tecnológicos', dentre os cinco itens originais, apenas dois se mantiveram: 'No Brasil, estamos provavelmente melhores que nunca, graças aos grandes progressos da tecnologia' e 'Através dos tempos, o conhecimento tecnológico tem sido a arma mais importante na luta pela vida'. Isso demonstra que tais itens são importantes para a amostra pesquisada.

\subsubsection{Análise de correlação - Valores e Atitudes X Consumo}

Com base nesses resultados, fez-se uma "aglomeração de variáveis", de acordo com suas médias, e então foi rodada uma análise de correlação (ou medida da força da associação) entre as variáveis, utilizando o coeficiente de correlação de Pearson.

A correlação entre duas variáveis reflete o grau em que essas variáveis estão relacionadas. A medida mais comum é a correlação de Pearson Product Moment Correlation (usualmente chamada de correlação de Pearson). Quando calculado em uma amostra, é designado pela letra "R" e às vezes é chamado de $\mathrm{R}$ de Pearson e reflete o grau de relação ou dependência linear entre duas variáveis $\mathrm{X}$ e $\mathrm{Y}$. Ele varia de 1 a -1 , a correlação 1 significando que existe uma relação linear positiva perfeita entre as variáveis, ou seja, Y aumenta à medida que $\mathrm{X}$ aumenta. $\mathrm{O}$ valor zero implica que não existe correlação linear entre as variáveis, e -1 implica que Y diminui à medida que X aumenta (UNIVERSITY OF THE WEST OF ENGLAND, 2007). Assim, quanto mais próximo de 1 for o resultado, maior a correlação positiva entre as variáveis. Os resultados estão expressos na Tabela 11. 
Tabela 11 - Análise de correlação entre as variáveis aglomeradas de Valores e Atitudes

\begin{tabular}{|c|c|c|c|c|c|c|c|c|c|}
\hline & \begin{tabular}{|l} 
Atitudes em \\
relação a \\
como a \\
produção de \\
alimentos \\
afeta o meio \\
ambiente \\
\end{tabular} & $\begin{array}{l}\text { Atitudes em } \\
\text { relação à } \\
\text { produção } \\
\text { industrial de } \\
\text { alimentos }\end{array}$ & $\begin{array}{l}\text { Atitudes em } \\
\text { relação aos } \\
\text { avanços } \\
\text { tecnológicos }\end{array}$ & \begin{tabular}{|} 
Atitudes em \\
relação ao \\
meio \\
ambiente e à \\
natureza
\end{tabular} & \begin{tabular}{|c|} 
\\
Atitudes \\
Etnocentrism \\
$\mathrm{o}$
\end{tabular} & \begin{tabular}{|c|} 
Valores - \\
Conformidade, \\
Poder e \\
Segurança
\end{tabular} & \begin{tabular}{|c} 
Valores - \\
Universalis \\
mo e \\
Benevolênci \\
a
\end{tabular} & \begin{tabular}{|c|} 
Valores - \\
Estímulo, \\
Realização e \\
Hedonismo
\end{tabular} & $\begin{array}{l}\text { Freq.consumo_ } \\
\text { frescos }\end{array}$ \\
\hline $\begin{array}{l}\text { Atitudes em } \\
\text { relação à produção } \\
\text { industrial de } \\
\text { alimentos }\end{array}$ & $-0,103^{*}$ & & & & & & & & \\
\hline $\begin{array}{l}\text { Atitudes em } \\
\text { relação aos } \\
\text { avanços } \\
\text { tecnológicos }\end{array}$ & $-0,245^{* *}$ & $-0,134^{* *}$ & & & & & & & \\
\hline $\begin{array}{l}\text { Atitudes em } \\
\text { relação ao meio } \\
\text { ambiente e à } \\
\text { natureza }\end{array}$ & 0,082 & $0,104^{*}$ & $-0,028$ & & & & & & \\
\hline $\begin{array}{l}\text { Atitudes } \\
\text { Etnocentrismo }\end{array}$ & $-0,158^{* * *}$ & $0,166^{* * *}$ & 0,010 & $0,143^{* * *}$ & & & & & \\
\hline $\begin{array}{l}\text { Valores - } \\
\text { Conformidade, } \\
\text { Poder e Segurança } \\
\end{array}$ & $-0,324^{* * *}$ & $-0,012$ & $0,215^{* *}$ & $0,103^{*}$ & $0,128^{* *}$ & & & & \\
\hline $\begin{array}{l}\text { Valores - } \\
\text { Universalismo e } \\
\text { Benevolência }\end{array}$ & $-0,045$ & 0,081 & $-0,167^{* *}$ & $-0,025$ & $0,206^{* *}$ & $0,159^{* *}$ & & & \\
\hline $\begin{array}{l}\text { Valores - } \\
\text { Estímulo, } \\
\text { Realização e } \\
\text { Hedonismo } \\
\end{array}$ & $-0,211^{* * *}$ & 0,049 & 0,058 & 0,021 & 0,055 & $0,303^{* * *}$ & $0,212^{* * *}$ & & \\
\hline $\begin{array}{l}\text { Freq.consumo } \\
\text { frescos } \\
\end{array}$ & 0,009 & $-0,096^{*}$ & 0,078 & 0,049 & 0,047 & 0,064 & 0,036 & $-0,112^{*}$ & \\
\hline $\begin{array}{l}\text { Freq.consumo } \\
\text { processados }\end{array}$ & 0,040 & $0,110^{*}$ & $-0,037$ & $-0,050$ & 0,060 & $-0,171^{* *}$ & 0,026 & $-0,009$ & $0,357^{* *}$ \\
\hline
\end{tabular}

Notas: * Correlação significante ao nível de 0,05 .

** Correlação significante ao nível de 0,01 . 
Os valores encontrados são todos bastantes baixos. Percebe-se pelos resultados que a correlação ou dependência entre as variáveis analisadas é baixa, ou seja, as atitudes e valores não são bons parâmetros para explicar o consumo.

\subsubsection{Análises de regressão entre atitudes e valores e o consumo de produtos frescos e processados}

Realizou-se então uma análise de regressão a fim de verificar se existe relação entre alguns grupos de variáveis identificadas no estudo. Os pressupostos da regressão foram verificados e os resíduos considerados normais.

A análise de regressão estuda o relacionamento entre uma variável chamada dependente e uma ou várias outras chamadas independentes. No presente estudo, utilizaram-se as mesmas aglomerações de atitudes e valores obtidas na seção anterior, como variáveis independentes (preditores), e o nível de escolaridade como variável de controle.

\section{Produtos processados}

Utilizando-se a frequência de consumo de produtos processados como variável dependente,

obteve-se um $\mathrm{R}^{2}$ de 0,078 , e o $\mathrm{R}$ ajustado de 0,060 , com erro padrão estimado de 1,15172 . Isso indica que $7,8 \%$ da variância da frequência de consumo de produtos processados pela amostra pesquisada pode ser explicada pela variância das variáveis independentes do modelo (valores e atitudes). Ou simplesmente que o modelo explica 7,8\% da variação da frequência de consumo de produtos de carne suína da categoria processados.

Utilizando o software PASW Statistics 18, procedeu-se à análise de variância (ANOVA), que é um teste estatístico amplamente difundido e visa fundamentalmente verificar se existe uma diferença significativa entre médias e se os fatores exercem influência em alguma variável dependente. Os fatores propostos podem ser de origem qualitativa ou quantitativa, mas a variável dependente necessariamente deverá ser contínua.

A tabela ANOVA gerada na regressão mostra um valor de $\mathrm{F}=4,440 \mathrm{com}$ um p-valor $<0,000$ (nível de significância estatística dos dados). Esses resultados permitem rejeitar a hipótese nula 
de que todos os coeficientes, exceto o beta zero, sejam iguais a zero e admite-se a hipótese alternativa de que pelo menos um dos coeficientes seja diferente de zero.

Os resultados mostraram que os únicos itens com significância estatística (p-valor <0,05) foram a 'Atitude em relação à produção industrial de alimentos', que obteve coeficiente beta padronizado de 0,103 (correlação positiva com a variável dependente) e nível de significância de 0,025, o que significa que, a cada variação de uma unidade de desvio padrão na variável 'Atitude em relação à produção industrial de alimentos', ocorrerá a variação de 0,103 unidades de desvio padrão na variável de frequência de consumo de produtos processados. Observe-se que, como se está tratando do coeficiente beta padronizado, fala-se em unidades de desvio padrão e não em unidades da variável.

Essa correlação positiva indica que os consumidores da amostra que possuem atitude positiva em relação à produção industrial de alimentos possuem também uma frequência positiva de consumo de produtos processados. Isso faz bastante sentido, uma vez que os produtos processados são muito industrializados e, portanto, devem ser mais consumidos por pessoas que apoiam esse tipo de produção.

Também os valores morais e hierárquicos ('Conformidade', 'Poder' e 'Segurança'), com beta padronizado de $-0,180$ (correlação negativa) e nível zero de significância. Isso mostra que a cada variação de uma unidade de desvio padrão na variável 'Valores - Conformidade, Poder e Segurança', ocorrerá a variação negativa de 0,180 unidades de desvio padrão da frequência de consumo de produtos processados.

Novamente, nota-se que as pessoas com valores mais tradicionais tendem a evitar os produtos mais processados, uma vez que se imagina que não se sabe ao certo "o que está incluído" no produto, quais foram os ingredientes utilizados, de que maneira foi preparado, e as pessoas tradicionais normalmente preferem preparar os produtos que consomem em casa desde o início, o que não é possível para os produtos processados.

\section{Produtos frescos}

Ao colocar como variável dependente a frequência de consumo de produtos frescos, obteve-se um $\mathrm{R}^{2}$ de 0,044 , ajustado como 0,026, com erro estimado padrão de 1,20747, o que significa que $4,4 \%$ da frequência de consumo de produtos processados pode ser explicada pelos valores e atitudes utilizados na análise. 
A análise de variância mostrou resultados importantes novamente para 'Atitude em relação à produção industrial', que obteve coeficiente beta padronizado de -0,94, com nível de significância de 0,046, e valores 'Estímulo', 'Realização' e 'Hedonismo' com beta padronizado de -0,146 ao nível de significância de 0,003. Novamente, esses resultados implicam que, a cada variação de uma unidade de desvio padrão na variável 'Atitude em relação à produção industrial', ocorrerá uma variação negativa de 0,94 unidades de frequência de consumo de produtos processados. Também, a cada variação de uma unidade de desvio padrão na variável 'Valores de Estímulo, Realização e Segurança', ocorrerá uma variação em sentido contrário de 0,146 unidades de desvio padrão da variável frequncia de consumo de produtos frescos. Aqui também se percebe que o consumo varia negativamente em relação a atitude em relação à produção industrial, o que confirma o resultado encontrado acima, ou seja, quem valoriza a produção industrial de alimentos tende a evitar produtos frescos. Também quem tem os valores que incluem 'hedonismo' tem características de mais “aventureiro", gosta de ter tempo livre para suas aventuras e, portanto, evita os produtos que dêem trabalho pra preparar, que é o caso dos produtos frescos.

\subsubsection{Análise de regressão entre atitudes e valores com os respondentes separados por gênero}

Separou-se, então, a amostra em gêneros para observar-se se havia algum resultado importante:

\section{Produtos frescos}

Ao dividir a amostra estudada entre os gêneros, obtiveram-se os seguintes resultados (mantidos como variáveis independentes os valores e atitudes, como variável de controle o nível de escolaridade, e como variável dependente a frequência de consumo de produtos frescos):

- mulheres: $\mathrm{R}^{2}$ igual a 0,060 , com $\mathrm{R}^{2}$ ajustado de 0,023 , e erro padrão estimado de 1,24579. Assim, 6\% da frequência de consumo de produtos frescos entre as mulheres da amostra pode ser explicada pelos valores e atitudes utilizados na análise. Houve apenas 
um fator ('Estímulo', 'Hedonismo’ e 'Realização') com importância observada pelo grau de significância, de 0,024, tendo obtido um coeficiente beta padronizado de -0,154. Implica que a cada variação de uma unidade de desvio padrão na variável 'Estímulo, Hedonismo e Realização', ocorrerá uma variação negativa de 0,154 unidades de desvio padrão da frequência de consumo de produtos frescos.

- homens: $\mathrm{R}^{2}$ de $0,051, \mathrm{R}^{2}$ ajustado de 0,014 e erro padrão estimado de 1,17761 . Novamente o mesmo fator foi o único que teve significância de 0,046 e beta padronizado de $-0,146$. Esses resultados significam que $5,1 \%$ da frequência de consumo de produtos frescos pelos homens da amostra pesquisada pode ser explicada pelos valores e atitudes incluídos na análise, e que a cada variação de uma unidade de desvio padrão da variável 'Estímulo, Hedonismo e Realização' ocorrerá uma variação em sentido contrário de 0,146 unidades de desvio padrão da frequência de consumo de produtos frescos.

Aqui novamente confirma-se que, independentemente do sexo, as pessoas com valores 'aventureiros' tendem a evitar os produtos frescos, que são mais trabalhosos e demandam mais tempo para ser preparados. Também pode ser porque os produtos frescos não possuem os atributos bastante valorizados atualmente por pessoas que gostam de dispor de tempo livre para lazer, que são a rapidez e facilidade no preparo, a conveniência e menor perecibilidade.

\section{Produtos processados}

Mantendo-se as variáveis independentes anteriormente analisadas, de valores e atitudes, e como variável de controle o nível de escolaridade, e incluindo como variável dependente a frequência de consumo de produtos processados, tem-se que:

- para as mulheres da amostra, obteve-se um $\mathrm{R}^{2}$ de 0,108 com erro padrão estimado de 1,15912, mostrando que $10,8 \%$ da frequência de consumo de produtos processados pode ser explicada pelos valores e atitudes utilizados na pesquisa. Obtiveram-se níveis de significância próximos de zero os fatores:

○ 'Valores de Conformidade, Poder e Segurança' - p-valor $=0,001$, com beta padronizado de -0,249, implicando que, a cada variação de uma unidade de desvio padrão da variável 'Valores de Conformidade, Poder e Segurança', ocorrerá uma variação negativa de 0,249 unidades de desvio padrão da 
frequência de consumo de produtos processados. Isso permite inferir que as mulheres com valores mais tradicionais tendem a consumir menos produtos processados, talvez por preferirem prepará-los 'em casa desde o início', tendo, portanto, controle sobre os ingredientes e a maneira de preparo do alimento que irá consumir.

○ 'Nível de Escolaridade' - p-valor = 0,001 e beta padronizado de 0,210, o que implica que, a cada variação de uma unidade de desvio padrão da variável 'Nível de Escolaridade', haverá uma variação de 0,210 unidades de desvio padrão da frequência de consumo de produtos processados. Daí pode-se imaginar que, conforme aumenta o grau de escolaridade da mulher, menos tempo ou menos disponibilidade ela terá para dispender cozinhando, o que faz aumentar o consumo de produtos processados. Talvez também ela tenha mais discernimento ao ler rótulos, notando que o que se acredita que as empresas “injetem” nos produtos não seja assim tão nocivo a sua saúde e à de sua família.

- para os homens da amostra, o $\mathrm{R}^{2}$ obtido foi de 0,095 com erro padrão de 1,13218. Temse daí que $9,5 \%$ da frequência de consumo de produtos processados pode ser explicada pelos valores e atitudes incluídos na pesquisa. Para esta análise, mais fatores tiveram níveis de significância estatística próximos de zero:

○ 'Atitudes em relação à produção industrial de alimentos' obteve um p-valor = 0,008 e beta padronizado de 0,175. Mais uma vez, pessoas com atitude favorável à industrialização de alimentos tendem a consumir mais produtos processados.

○ 'Atitudes em relação à preservação ambiental', com p-valor $=0,031$ e beta padronizado de $-0,143$, implicando que, para cada variação de uma unidade de desvio padrão da variável em questão, haverá uma variação negativa de 0,031 unidades de desvio padrão da variável frequência de consumo de produtos processados. Ou seja, pessoas (neste caso, homens) que são ditas "mais ambientalistas" tendem a evitar o consumo de produtos processados.

○ 'Valores de Conformidade, Poder e Segurança' ( $\mathrm{p}$-valor $=0,048$ ) com beta padronizado de $-0,138$, o que implica que, para cada variação de uma unidade de desvio padrão da variável em questão, haverá uma variação negativa de 0,138 unidades de desvio padrão da variável frequência de consumo de produtos 
processados. Aqui, novamente, homens com valores mais tradicionais também tendem a evitar consumir produtos processados, preferindo prepará-los em casa desde o início e saberem com o que e como foram preparados.

○ 'Nível de Escolaridade' - p-valor = 0,029 e beta padronizado de 0,141, o que implica que, a cada variação de uma unidade de desvio padrão da variável 'Nível de Escolaridade', haverá uma variação de 0,141 unidades de desvio padrão da frequência de consumo de produtos processados. Neste caso, assim como as mulheres, conforme aumenta o nível de escolaridade dos homens, estes tendem a aumentar o consumo de produtos processados.

Mesmo com esses resultados, os valores encontrados em geral são baixos. Assim, percebe-se que os valores e atitudes e o gênero são preditores fracos para a frequência de consumo de carne suína e produtos derivados, tanto para produtos frescos quanto para processados, ainda que para os produtos processados os valores de $\mathrm{R}$ de Pearson tenham sido bem mais elevados que os de produtos frescos.

\subsubsection{Análise de regressão entre atitudes e valores com os respondentes separados por idade}

\section{Produtos frescos}

Mantendo-se as variáveis independentes de valores e atitudes anteriormente analisadas, o nível de escolaridade como variável de controle, variável dependente a frequência de consumo de produtos frescos, a divisão por gênero, e incluindo uma divisão por idades, tem-se que:

- Para as mulheres da amostra pesquisada com mais de 55 anos, foram encontrados três resultados estatisticamente significantes:

○ 'Valores Estímulo, Hedonismo e Realização' obtiveram nível de significância de 0,043 e beta padronizado de 0,281 - anteriormente obteve-se uma correlação negativa em relação aos produtos frescos para mulheres com os valores 
denominados "aventureiros". No entanto, ao inserir-se a variável idade, este passou a ser positivo, o que pode significar que as mulheres mais velhas, ainda que tenham valores "aventureiros", disponham de mais tempo para cozinhar que as com menos idade e portanto ainda prefiram consumir produtos frescos, que possam preparar em casa desde o início.

- 'Valores de Conformidade, Poder e Segurança', com nível de significância de 0,004 e beta padronizado de $-0,420$ - na análise de regressão anterior, para as mulheres em geral, não foram encontrados valores de beta padronizado significativos em relação a produtos frescos, porém com relação aos produtos processados ela foi negativa. Já neste caso, para mulheres com mais de 55 anos, a correlação passou a ser negativa também em relação a produtos frescos, mostrando que mulheres com esses valores, com maior sentido moral e hierárquico, consomem menos produtos frescos de carne suína.

- 'Atitudes em relação ao meio ambiente', com nível de significância de 0,061 e beta padronizado de -0,265 - aqui mais uma vez encontra-se correlação negativa entre atitudes e o consumo de produtos frescos. Somado ao item anterior, em que aparece novamente a correlação negativa entre mulheres com mais de 55 anos e o consumo de produtos frescos, poder-se-ia imaginar que essa diminuição no consumo deve-se mais à idade que aos valores propriamente ditos, e isso seria contrariado somente pelas mulheres que apresentam elevados valores “aventureiros", já que tenderiam a um maior consumo dos produtos frescos.

- Entre os homens da amostra com mais de 55 anos, não houve nenhum resultado significativo estatisticamente.

- Entre as mulheres de 35 a 55 anos houve dois resultados significativos:

- 'Atitudes em relação ao meio ambiente', com nível de significância de 0,050 e beta padronizado de 0,287 - para as mulheres nesta idade, uma mais alta atitude "ambientalista" leva a um maior consumo de alimentos frescos, que são considerados mais naturais. Isso confirma o resultado encontrado anteriormente, porém entre os homens e sem distinção de idade.

○ 'Valores Estímulo, Hedonismo e Realização' obtiveram nível de significância de 0,005 e beta padronizado de $-0,398$ - conforme o resultado anterior relacionando mulheres aos valores "aventureiros e de liberdade", sem distinção de idade, 
tem-se que estes variam negativamente em relação ao consumo de produtos frescos, provavelmente pelos mesmos motivos apresentados anteriormente, de que mulheres com esses valores querem maior tempo livre e portanto preferem consumir produtos de mais fácil e rápido preparo, maior conveniência e menor perecibilidade, atributos que não estão presentes nos produtos frescos.

- Entre os homens de 35 a 55 anos, foram observados três resultados significantes estatisticamente:

- 'Atitudes em relação à preservação ambiental', cujo nível de significância foi de 0,046 e beta padronizado de -0,314 - indica que os homens dessa idade com valores "ambientalistas" consomem menos produtos frescos, possivelmente porque, principalmente nos estados da região sul, a produção de suínos tem causado danos significativos ao meio ambiente.

○ 'Atitudes em relação ao etnocentrismo', com nível de significância de 0,044 e beta padronizado de 0,316 - é possível que essas pessoas com atitudes favoráveis ao etnocentrismo tenham um maior consumo de produtos frescos por olharem pelo lado agregado da cadeia produtiva, bastante importante na geração de empregos para o país, e que conta com grandes empresas nacionais que crescentemente estão investindo na venda de cortes frescos de carne suína.

○ 'Valores Estímulo, Hedonismo e Realização' obtiveram nível de significância de 0,005 e beta padronizado de -0,546 - novamente encontra-se uma correlação negativa entre os valores "aventureiros e de liberdade" e o consumo de produtos frescos, possivelmente indicando entre as pessoas com esses valores uma maior preferência por produtos mais convenientes, fáceis de preparar e menos perecíveis, ao contrário dos produtos frescos.

- Para as mulheres com menos de 35 anos, encontraram-se dois resultados significativos:

○ 'Atitudes em relação à produção industrial', com nível de significância de 0,010 e beta padronizado de -0,271 - indica que as pessoas com atitudes positivas em relação à produção industrial vão preferir produtos processados em detrimento dos produtos frescos.

○ 'Valores Estímulo, Hedonismo e Realização' obtiveram nível de significância de 0,034 e beta padronizado de $-0,215$ - novamente aparece a mesma correlação 
negativa entre tais valores e o consumo de produtos frescos, confirmando o já exposto anteriormente.

- Entre os homens com menos de 35 anos, nenhum resultado estatisticamente significativo foi encontrado. Isto quer dizer que não há correlação estatisticamente significativa entre os valores e atitudes da pesquisa, a frequência de consumo e o sexo ou a idade dos respondentes na amostra pesquisada.

Testaram-se ainda as diferenças entre os índices do Índice de Massa Corporal (IMC) e não foram encontrados resultados significativos. Também entre as cidades não apareceram resultados significativos na regressão analisada.

Analisando-se entre os diferentes estados, percebeu-se que todos são diferentes entre si em relação ao meio ambiente. Também percebeu-se que a média de consumo do Rio Grande do Sul é maior que a de todos os outros estados, o que confirma pesquisas divulgadas de que o consumo de carne suína naquele estado é muito maior do que a média brasileira, situando-se em 22 kg/hab/ano, enquanto a média nacional é de $13 \mathrm{~kg} / \mathrm{hab} / \mathrm{ano}$ (CANAL DO PRODUTOR, 2011). Segundo a publicação, "é uma questão cultural. O sul é a maior região consumidora pela presença germânica".

De todos esses resultados, pode-se inferir que a correlação entre as variáveis é bastante baixa, ou seja, confirma-se mais uma vez, conforme já testado anteriormente neste trabalho, que as atitudes e valores dos consumidores não são bons preditores da frequência de compra de carne suína. Em outras palavras, o que os consumidores pensam a respeito dos valores questionados (estímulo, poder, segurança, etc.), ou das atitudes (em relação ao meio ambiente ou à produção industrial de alimentos, entre várias outras) tem pouco poder de explicar a frequência de consumo de produtos de carne suína.

Talvez se tivessem sido incluídos construtos como o hábito, a cultura ou a renda dos consumidores, fosse possível ter encontrado resultados mais relevantes estatisticamente. Segundo Levi-Strauss (1973, apud ALMEIDA et al, 2009): “[...] nossos hábitos alimentares fazem parte de um sistema cultural repleto de símbolos, significados e classificações, de modo que nenhum alimento está livre das associações culturais que a sociedade lhes atribui”. Barcellos também confirma a importância da cultura (2007, p. 227) e do hábito (2007, p. 222) na relação entre os consumidores e os alimentos. 


\subsubsection{Atitudes do cidadão em relação aos sistemas de produção de suínos}

Foi realizado um estudo de análise conjunta (Conjoint Analysis) a fim de avaliar as atitudes dos respondentes em relação aos sistemas de produção de suínos. A tabela abaixo demonstra os resultados obtidos.

Tabela 12 - Média e desvio padrão das utilidades da pesquisa

\begin{tabular}{|c|c|c|}
\hline \multicolumn{3}{|l|}{ Utilidades } \\
\hline & Média & $\begin{array}{l}\text { Desvio } \\
\text { padrão }\end{array}$ \\
\hline Baixa densidade de produção (< 100 suínos) & ,076 & ,887 \\
\hline Densidade média (400 suínos) & 016 & ,930 \\
\hline Alta densidade (>800 suínos) &,- 091 &, 812 \\
\hline Alojamento em piso ripado & ,289 & 1,047 \\
\hline Alojamento em palha &,- 483 & 1,628 \\
\hline Alojamento ao ar livre & ,194 & 1,101 \\
\hline Esforço mínimo para reduzir impacto ambiental &,- 636 & 1,214 \\
\hline Esforço médio para reduzir impacto ambiental & 047 &, 850 \\
\hline $\begin{array}{l}\text { Esforço máximo para reduzir impacto } \\
\text { ambiental }\end{array}$ &, 589 & 1,296 \\
\hline $\begin{array}{l}\text { Alimentação animal para produção de carne } \\
\text { com teor de gordura padrão }\end{array}$ &,- 434 & ,993 \\
\hline $\begin{array}{l}\text { Alimentação animal para produção de carne } \\
\text { com baixo teor de gordura (light) }\end{array}$ & ,099 & 1,012 \\
\hline $\begin{array}{l}\text { Alimentação animal para produção de carne } \\
\text { com teor de gordura saudável }\end{array}$ & ,335 & ,906 \\
\hline Produção de suínos com qualidade constante & ,112 & ,674 \\
\hline Produção de suínos com qualidade diferente & ,016 & ,811 \\
\hline $\begin{array}{l}\text { Produção de suínos com qualidade exigida pelo } \\
\text { cliente }\end{array}$ &,- 128 &, 781 \\
\hline
\end{tabular}

Observa-se maior utilidade ou nível de preferência para os atributos baixa densidade de produção, alojamento em piso ripado, esforço máximo para reduzir o impacto ambiental, alimentação animal para produção de carne com teor de gordura saudável e produção de suínos com qualidade constante. 
Os gráficos a seguir ilustram essas utilidades.

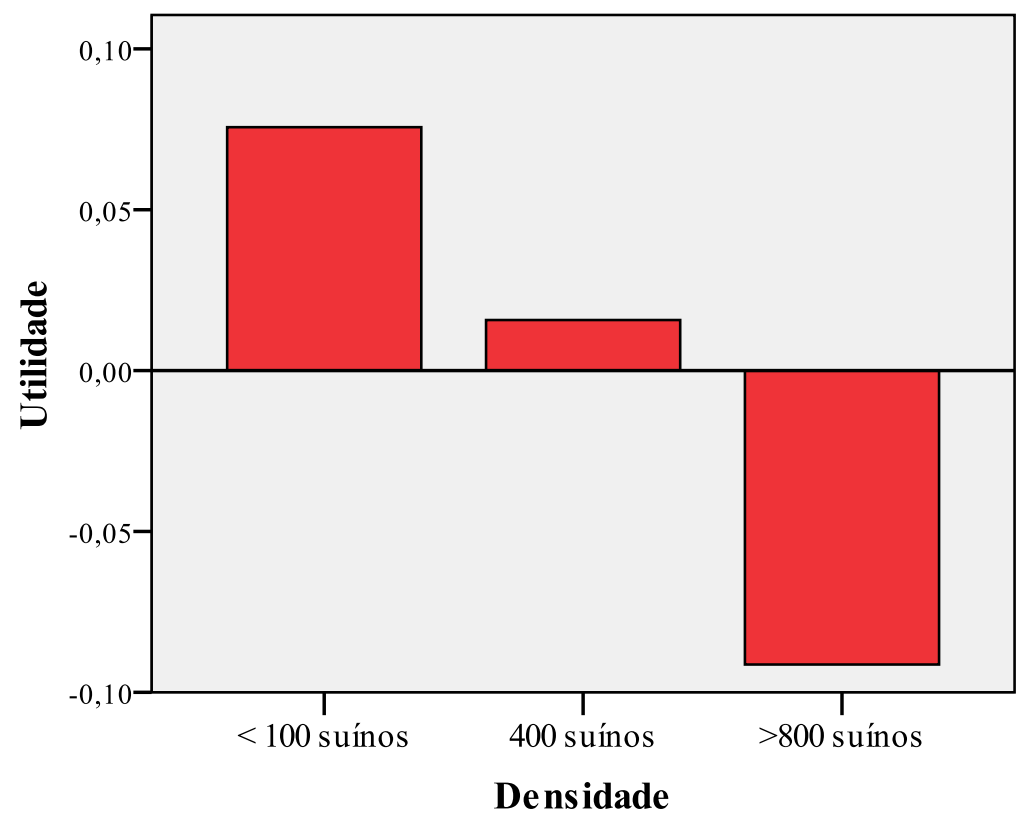

Gráfico 2 - Utilidades da densidade da produção de suínos

De maneira geral, a mais baixa densidade (até 100 suínos) é a preferida, seguida pela média (por volta de 400 suínos), enquanto a alta densidade (acima de 800 suínos) chega a ter preferência negativa. 


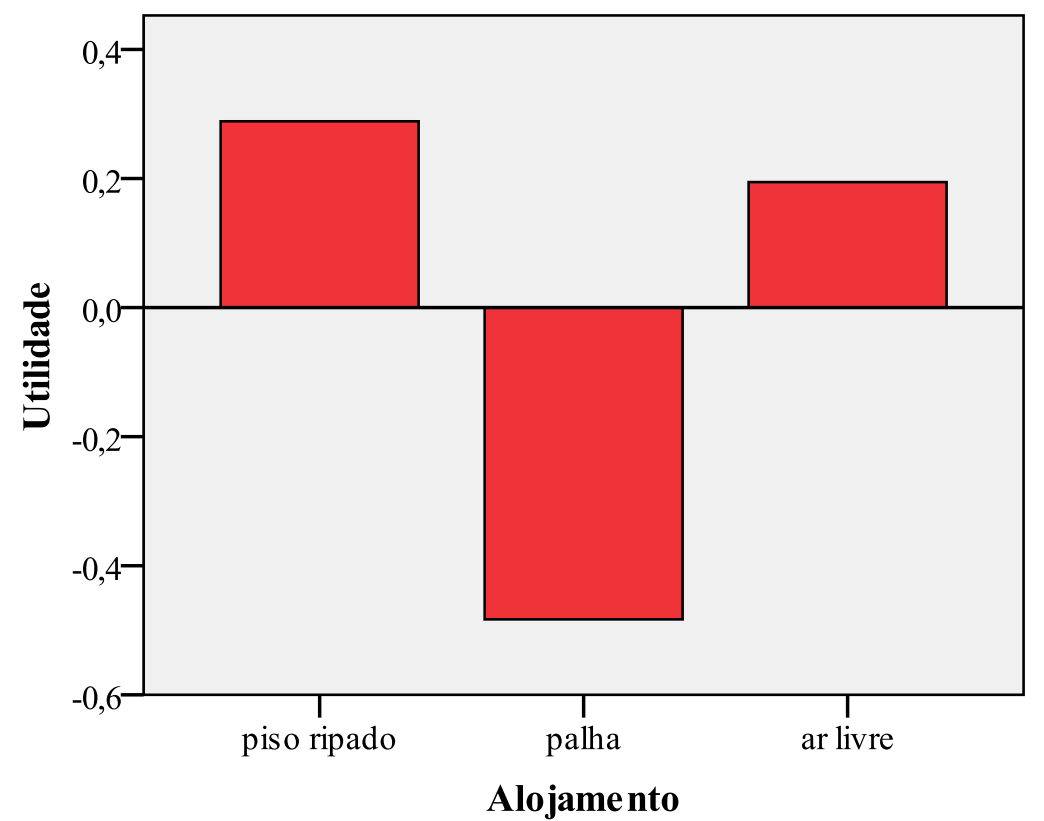

Gráfico 3 - Utilidades do alojamento da produção

Observa-se que há pouca diferença de preferências entre o alojamento da produção de suínos em piso ripado e ao ar livre, mas que o de palha (possivelmente relacionado à antiga criação de suínos nos chamados "chiqueiros") tem preferência negativa.

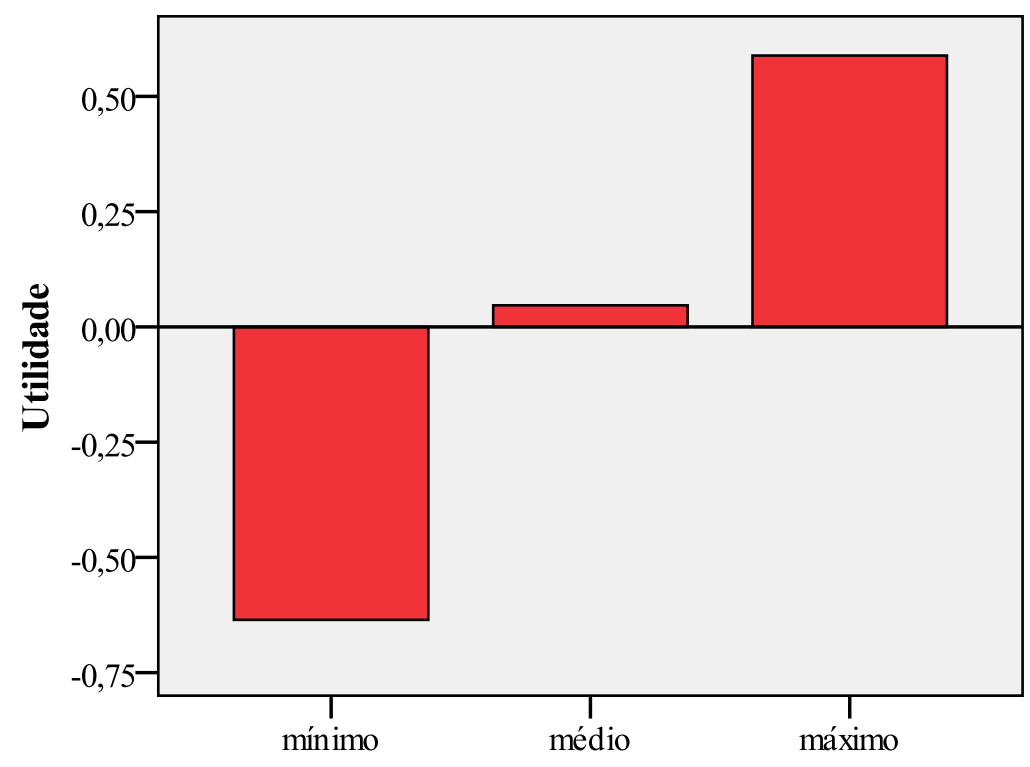

Esforço para reduzir impacto ambiental

Gráfico 4 - Utilidades do esforço para diminuir impacto ambiental 
O esforço para reduzir o impacto ambiental varia de preferência do consumidor conforme sua utilização, ou seja, o máximo esforço é o preferido, o médio tem pouca preferência e o mínimo é de certa maneira rejeitado pelo consumidor da amostra estudada.

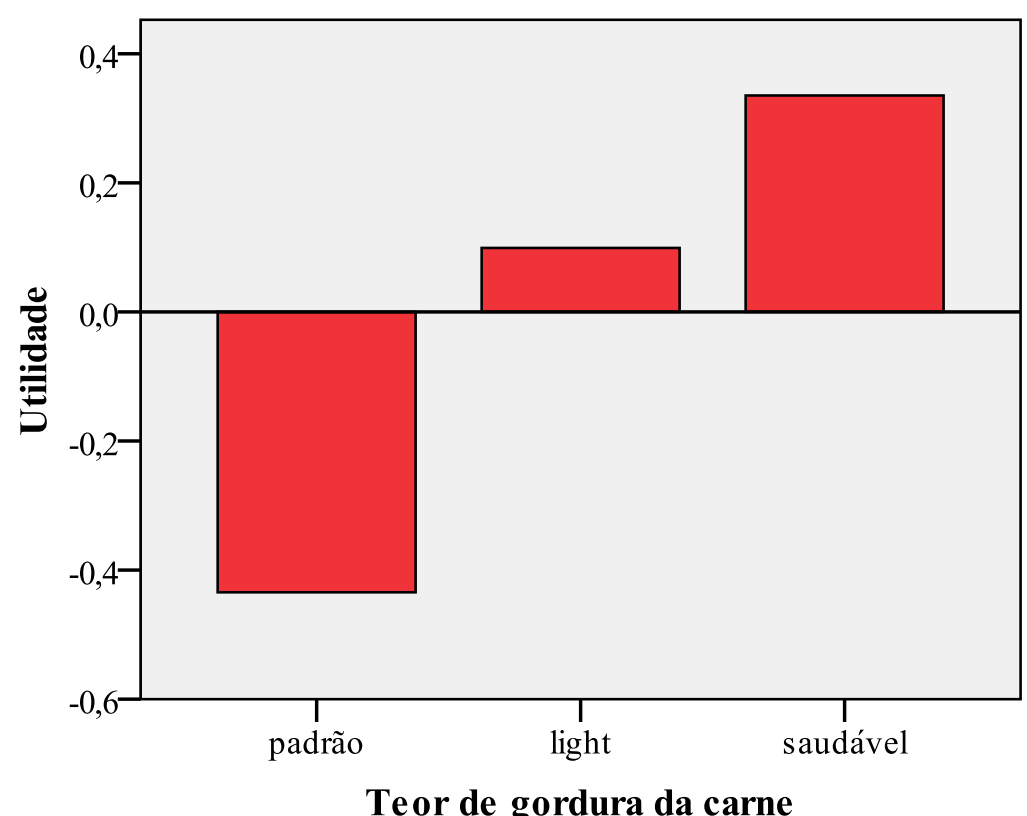

Gráfico 5 - Utilidades para o teor de gordura da carne

Quanto ao teor de gordura da carne, o suíno criado para oferecer teor de gordura saudável é o preferido, provavelmente porque se sabe que a gordura também está relacionada ao sabor do produto. Assim, um pouco de gordura, em níveis considerados "saudáveis" tem alguma preferência sobre a gordura chamada de light e muita preferência sobre a produção de suínos para obtenção de animais com gordura 'padrão'. 


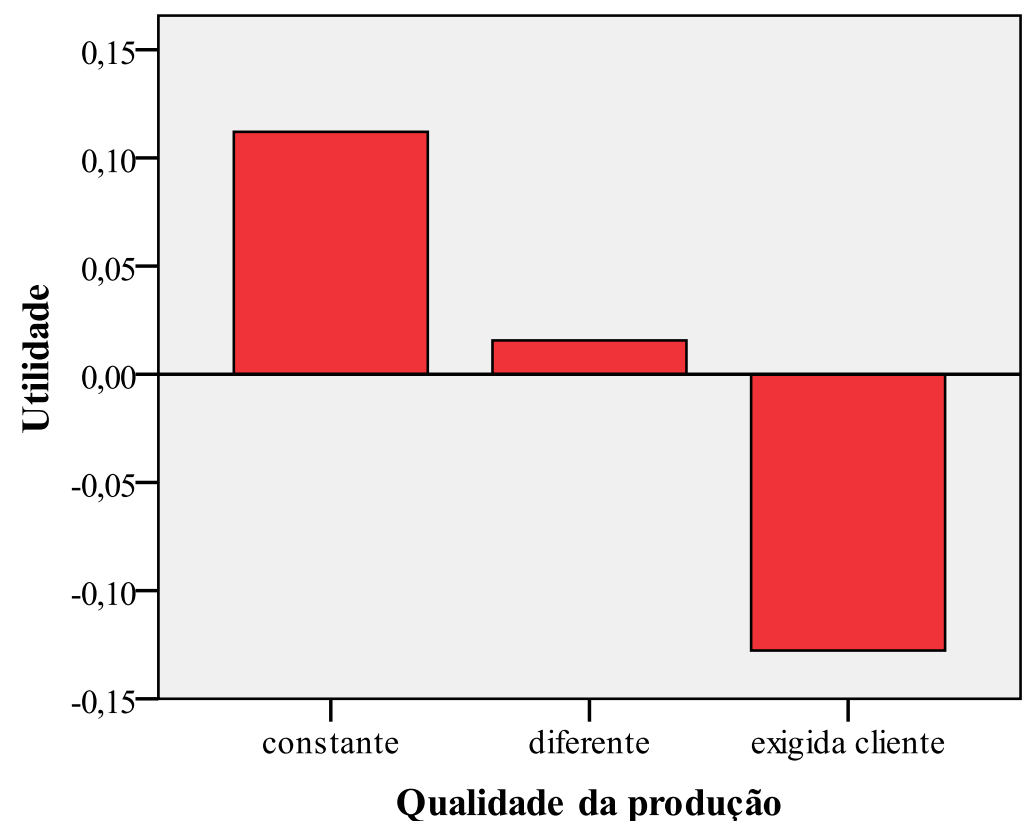

Gráfico 6 - Utilidades para a qualidade da produção

Quanto à qualidade da produção, o consumidor da amostra estudada prefere a produção visando a uma qualidade constante nos animais produzidos.

Observa-se no gráfico a seguir que, dentre todos os atributos do estudo, o esforço para reduzir o impacto ambiental é a variável mais relevante no modelo (24,73\%), seguida pelo tipo de alojamento $(22,36 \%)$ e pelo teor de gordura da carne $(20,74 \%)$. Ou seja, esses são os atributos preferidos pelo consumidor da amostra estudada. 


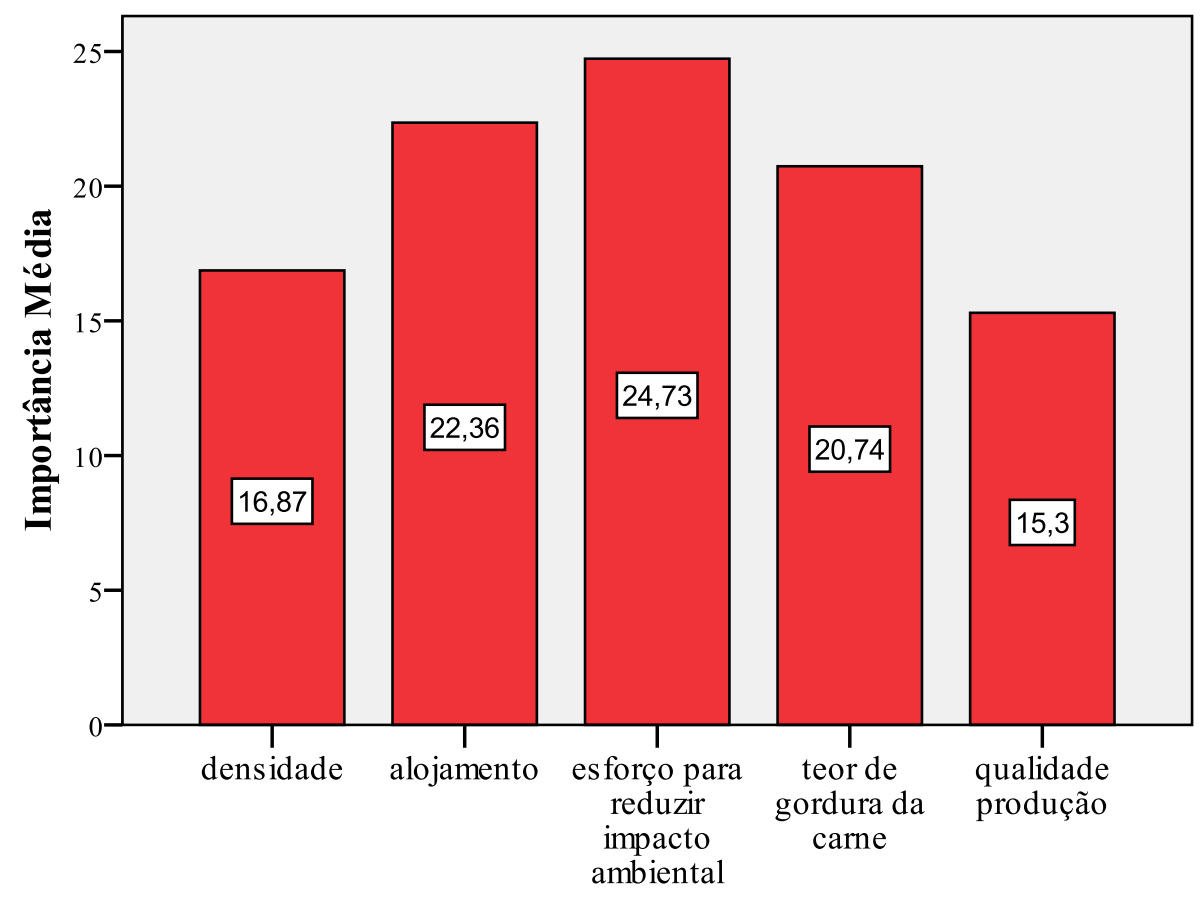

Gráfico 7 - Utilidades da pesquisa

A Tabela 13, a seguir, apresenta as utilidades médias por cidade. Observa-se diferença de comportamento entre elas.

Tabela 13 - Utilidades médias da amostra por cidade

\begin{tabular}{|c|c|c|c|c|c|c|c|c|}
\hline & $\begin{array}{l}\text { Porto } \\
\text { Alegre }\end{array}$ & $\begin{array}{l}\text { Santa } \\
\text { Rosa }\end{array}$ & Curitiba & $\begin{array}{l}\text { Ponta } \\
\text { Grossa }\end{array}$ & Cuiabá & \begin{tabular}{|l|} 
Campo \\
Verde
\end{tabular} & Goiânia & \begin{tabular}{|l} 
Rio \\
Verde
\end{tabular} \\
\hline $\begin{array}{l}\text { Baixa densidade de produção }(< \\
100 \text { suínos) }\end{array}$ &,- 142 &, 055 & ,289 &,- 019 & $\mathbf{0 8 9}$ &,- 168 & ,244 & ,277 \\
\hline Densidade média (400 suínos) &,- 031 &,- 067 &, 004 &,- 004 &,- 081 & ,253 &,- 056 &, 130 \\
\hline Alta densidade (>800 suínos) & ,173 &, 012 &,- 292 &, 022 &,- 008 &,- 085 &,- 188 &,- 407 \\
\hline Alojamento em piso ripado &,- 085 & 1,847 &,- 030 &,- 059 &, 050 & ,327 & ,259 &,- 091 \\
\hline Alojamento na palha &, 024 & $-3,762$ &,- 040 &,- 060 &, 151 &,- 055 &,- 189 & ,258 \\
\hline Alojamento ao ar livre & ,061 & 1,915 & ,070 & ,119 &,- 202 &,- 272 &,- 070 &,- 167 \\
\hline $\begin{array}{l}\text { Esforço mínimo para reduzir } \\
\text { impacto ambiental }\end{array}$ &,- 525 & $-1,606$ &,- 086 &,- 040 &,- 865 & $-1,300$ &,- 569 &, 005 \\
\hline $\begin{array}{l}\text { Esforço médio para reduzir impacto } \\
\text { ambiental }\end{array}$ &,- 014 &, 361 & ,139 & ,058 &,- 106 & ,063 &,- 218 & ,090 \\
\hline
\end{tabular}




\begin{tabular}{|c|c|c|c|c|c|c|c|c|}
\hline $\begin{array}{l}\text { Esforço máximo para reduzir } \\
\text { impacto ambiental }\end{array}$ & ,539 & 1,246 &,- 053 &,- 018 & ,971 & 1,237 & ,786 &,- 095 \\
\hline $\begin{array}{l}\text { Alimentação animal para produção } \\
\text { de carne com teor de gordura } \\
\text { padrão }\end{array}$ &,- 227 &,- 523 &,- 207 & ,037 &,- 902 &,- 884 &,- 477 &,- 270 \\
\hline $\begin{array}{l}\text { Alimentação animal para produção } \\
\text { de carne com baixo teor de gordura } \\
\text { (light) }\end{array}$ & ,056 & , 145 &,- 025 &,- 183 & ,170 & ,178 & ,150 & ,327 \\
\hline $\begin{array}{l}\text { Alimentação animal para produção } \\
\text { de carne com teor de gordura } \\
\text { saudável }\end{array}$ & ,171 & ,377 & ,232 & 147 & ,732 & ,706 & ,327 &,- 057 \\
\hline $\begin{array}{l}\text { Produção de suínos com qualidade } \\
\text { constante }\end{array}$ &,- 028 & ,407 & ,273 &,- 025 &,- 037 & ,192 & ,044 & 057 \\
\hline $\begin{array}{l}\text { Produção de suínos com qualidade } \\
\text { diferente }\end{array}$ & ,027 &,- 420 &,- 008 & ,016 & ,206 & ,137 & ,108 & ,081 \\
\hline $\begin{array}{l}\text { Produção de suínos com qualidade } \\
\text { exigida pelo cliente }\end{array}$ & ,002 &, 012 &,- 265 & ,008 &,- 169 &,- 329 &,- 152 &,- 137 \\
\hline
\end{tabular}

$\mathrm{O}$ ajuste do modelo é mensurado pelo $\mathrm{R}$ de Pearson. $\mathrm{O}$ modelo possui $\mathrm{R}=0,993$, o que indica ajuste adequado do modelo.

Tabela 14 - Valores médios e desvio padrão das utilidades agregadas

\begin{tabular}{lc|c}
\hline \multicolumn{1}{l}{ Utilidades } & Média & Desvio Padrão \\
\hline Baixa densidade da produção (<100 suínos) & $\mathbf{0 , 1 3 6}$ & 0,081 \\
Densidade média (400 suínos) & $-0,081$ & 0,091 \\
Alta densidade (>800 suínos) & $-0,055$ & 0,091 \\
\hline Alojamento em piso ripado & $\mathbf{0 , 3 3 8}$ & 0,083 \\
Alojamento na palha & $-0,567$ & 0,096 \\
Alojamento ao ar livre & 0,229 & 0,091 \\
\hline Esforço mínimo para reduzir impacto ambiental & $-0,576$ & 0,081 \\
\hline Esforço médio para reduzir impacto ambiental & $-0,050$ & 0,091 \\
\hline Esforço máximo para reduzir impacto ambiental & $\mathbf{0 , 6 2 6}$ & 0,091 \\
\hline $\begin{array}{l}\text { Alimentação animal para produção de carne com teor de } \\
\text { gordura padrão }\end{array}$ & $-0,373$ & 0,083 \\
\hline
\end{tabular}




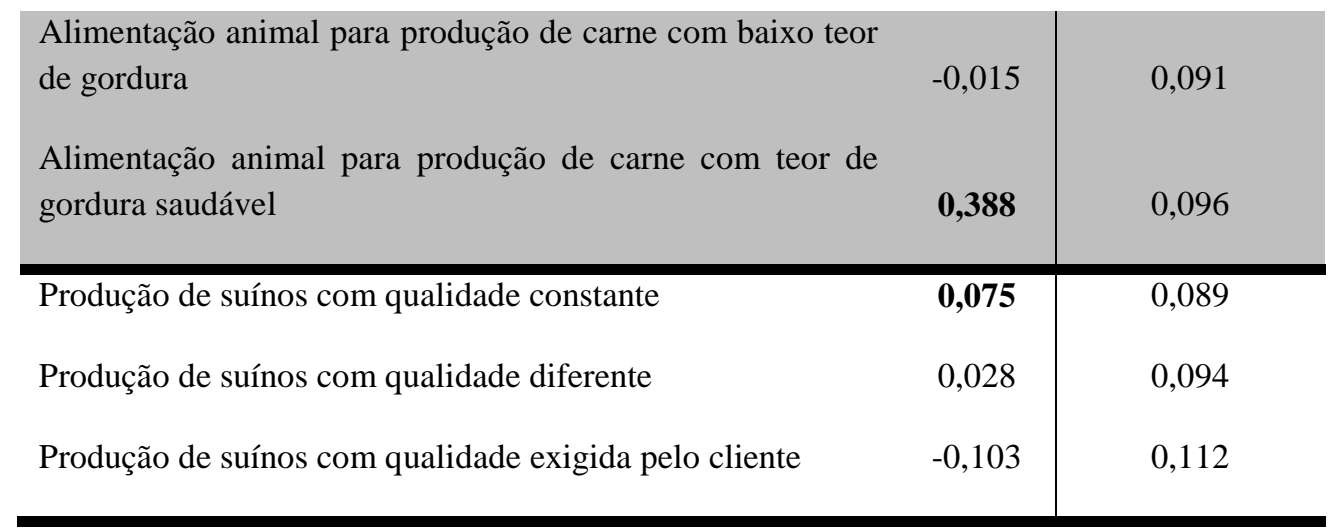

* $\mathrm{R}$ de Pearson $(0,987)$ e tau de Kendall $(0.943)$

Percebe-se que os consumidores preferem produções com máximo esforço para reduzir o impacto ambiental (utilidade média de 0,626) e criações com baixa densidade de produção (menos de 100 animais). Já com relação ao tipo de piso, o piso ripado (de madeira ou metal) e o alojamento com acesso ao ar livre são os preferidos (0,338 e 0,229, respectivamente). A limpeza do alojamento pode ser um fator importante para explicar esse resultado, uma vez que normalmente, nesse sistema, o esterco não ficaria em contato com os animais. Além disso, o alojamento externo é a maneira tradicional da criação de suínos no Brasil, devido à facilidade do clima.

Finalmente, criações onde os animais são alimentados de forma a produzirem carne com gordura saudável e qualidade constante são as preferidas.

Assim, um tipo de produção ideal para agradar ao consumidor brasileiro, com base na amostra estudada, teria as seguintes características:

- máximo esforço para reduzir o impacto ambiental;

- baixa densidade de produção (menos de 100 animais);

- $\quad$ piso ripado (de madeira ou metal);

- alojamento com acesso ao ar livre;

- animais são alimentados de forma a produzirem carne com gordura saudável e qualidade constante.

A Tabela 15 apresenta ainda os valores médios das utilidades agregadas geral e por cidade. 
Tabela 15 - Valores médios das utilidades agregadas (geral e por cidade)

\begin{tabular}{|c|c|c|c|c|c|c|c|c|c|}
\hline Utilidades/Cidades & $\begin{array}{l}\text { Brasil } \\
(\mathrm{n}=48 \\
2)\end{array}$ & $\begin{array}{l}\text { Porto } \\
\text { Alegre } \\
(n=60)\end{array}$ & $\begin{array}{l}\text { Santa } \\
\text { Rosa } \\
(n=62)\end{array}$ & $\begin{array}{l}\text { Curitiba } \\
(n=60)\end{array}$ & $\begin{array}{l}\text { Ponta } \\
\text { Grossa } \\
(n=60)\end{array}$ & $\begin{array}{l}\text { Cuiabá } \\
(n=61)\end{array}$ & $\begin{array}{l}\text { Campo } \\
\text { Verde } \\
(n=59)\end{array}$ & $\begin{array}{l}\text { Goiânia } \\
(\mathrm{n}=60)\end{array}$ & $\begin{array}{c}\text { Rio } \\
\text { Verde } \\
(n=60)\end{array}$ \\
\hline $\begin{array}{l}\text { Baixa densidade de } \\
\text { produção }(<100 \text { suínos) }\end{array}$ & 0,136 & $-0,118$ & 0,142 & 0,315 & $-0,029$ & $\mathbf{0 , 1 7 3}$ & $-0,090$ & $\mathbf{0 , 3 2 8}$ & 0,367 \\
\hline $\begin{array}{l}\text { Densidade média (400 } \\
\text { suínos)* }\end{array}$ & $-0,081$ & $-0,078$ & $-0,194$ & $-0,033$ & $-0,012$ & $-0,216$ & 0,094 & $-0,149$ & $-0,048$ \\
\hline $\begin{array}{l}\text { Alta densidade (>800 } \\
\text { suínos) }\end{array}$ & $-0,055$ & 0,197 & 0,052 & $-0,283$ & 0,041 & 0,042 & $-0,004$ & $-0,179$ & $-0,319$ \\
\hline $\begin{array}{l}\text { Alojamento em piso } \\
\text { ripado }\end{array}$ & $\mathbf{0 , 3 3 8}$ & $-0,051$ & 1,911 & $-0,020$ & $-0,065$ & $\mathbf{0 , 1 0 7}$ & 0,519 & 0,299 & $-0,083$ \\
\hline Alojamento na palha & $-0,567$ & $-0,021$ & $-3,873$ & $-0,068$ & $-0,015$ & $-0,038$ & $-0,261$ & $-0,235$ & 0,147 \\
\hline Alojamento ao ar livre & 0,229 & 0,072 & 1,962 & $\mathbf{0 , 0 8 8}$ & $\mathbf{0 , 0 8 0}$ & $-0,069$ & $-0,258$ & $-0,064$ & $-0,064$ \\
\hline $\begin{array}{lr}\text { Esforço } & \text { mínimo para } \\
\text { reduzir } & \text { impacto } \\
\text { ambiental } & \end{array}$ & $-0,576$ & $-0,490$ & $-1,528$ & $-0,068$ & $-0,014$ & $-0,687$ & $-1,200$ & $-0,618$ & 0,080 \\
\hline $\begin{array}{lr}\text { Esforço } & \text { médio para } \\
\text { reduzir } & \text { impacto } \\
\text { ambiental } & \end{array}$ & $-0,050$ & $-0,059$ & 0,232 & 0,101 & 0,097 & $-0,287$ & $-0,133$ & $-0,297$ & $-0,058$ \\
\hline $\begin{array}{lr}\text { Esforço } & \text { máximo para } \\
\text { reduzir } & \text { impacto } \\
\text { ambiental } & \end{array}$ & 0,626 & 0,549 & 1,296 & $-0,033$ & $-0,083$ & 0,975 & $1, \mathbf{3 3 3}$ & $\mathbf{0 , 9 1 5}$ & $-0,023$ \\
\hline Gordura padrão & $-0,373$ & $-0,201$ & $-0,360$ & $-0,186$ & 0,032 & $-0,781$ & $-0,721$ & $-0,506$ & $-0,235$ \\
\hline Baixo teor de gordura* & $-0,015$ & 0,022 & $-0,110$ & $-0,079$ & $-0,120$ & $-0,094$ & 0,029 & 0,083 & 0,157 \\
\hline Gordura saudável & 0,388 & 0,179 & 0,470 & 0,265 & $\mathbf{0 , 0 8 8}$ & 0,875 & 0,692 & 0,424 & 0,078 \\
\hline Qualidade constante & 0,075 & $-0,036$ & 0,361 & 0,251 & $-0,018$ & $-0,114$ & 0,233 & $-0,022$ & $-0,069$ \\
\hline Qualidade diferente & 0,028 & 0,042 & $-0,413$ & $-0,011$ & $-0,005$ & 0,286 & 0,187 & $\mathbf{0 , 0 8 5}$ & 0,067 \\
\hline $\begin{array}{l}\text { Qualidade } \\
\text { customizada* }\end{array}$ & $-0,103$ & $-0,006$ & 0,052 & $-0,240$ & 0,023 & $-0,172$ & $-0,420$ & $-0,064$ & 0,001 \\
\hline
\end{tabular}

Notas: As utilidades preferidas estão em negrito.

*Nenhuma diferença estatisticamente significativa entre as cidades. 
Algumas diferenças encontradas entre as regiões sul e centro-oeste indicam que os consumidores no sul são mais favoráveis à criação intensiva, porém também mais favoráveis ao bem-estar animal, que estaria ligado ao acesso externo.

Na região sul, o Paraná e o Rio Grande do Sul diferem em relação ao impacto ambiental das criações de suínos; os consumidores do Rio Grande do Sul são mais favoráveis a criações com baixo impacto ambiental.

O impacto do sistema de produção de suínos no meio ambiente (solo, ar e água) é o fator mais importante para os consumidores brasileiros $(24,0 \%)$ e a densidade da produção é o menos importante $(17,3 \%)$ quando considerada a preferência geral.

\subsubsection{Comportamento de consumo}

\subsubsection{Penetração de mercado}

Inicialmente, verificaram-se os níveis de penetração de mercado dos produtos pesquisados, obtendo-se alguns resultados interessantes:

- em geral, os brasileiros comem produtos de suínos pelo menos uma vez por ano. O pernil tem a mais alta penetração na amostra observada, entre os 11 produtos;

- embutidos, como salames, presunto e mortadela, também têm alta penetração, seguidos de costela de porco, lombo e bisteca, salsichas e alguns pratos como feijoada;

- patê é o produto menos consumido entre os pesquisados, com uma penetração de menos de $50 \%$, seguido de miúdos (rabo, toucinho, orelha);

- os produtos da categoria de frescos primariamente processados (carne recheada, carne assada, marinados, temperados) também têm pequena penetração e podem representar uma boa oportunidade para as indústrias introduzirem uma variedade maior desse tipo de produto no Brasil, e até mesmo desenvolver produtos desse tipo mais de acordo com o paladar do brasileiro;

- outra oportunidade é aumentar a disponibilidade desses produtos no ponto de venda, principalmente supermercados e açougues. 
É importante observar que a penetração não mostra frequência de consumo ou níveis reais de consumo. De fato, diz mais a respeito da familiaridade do respondente com o produto do que se ele gosta ou não do produto.

O Gráfico 8 facilita a visualização deste conceito.

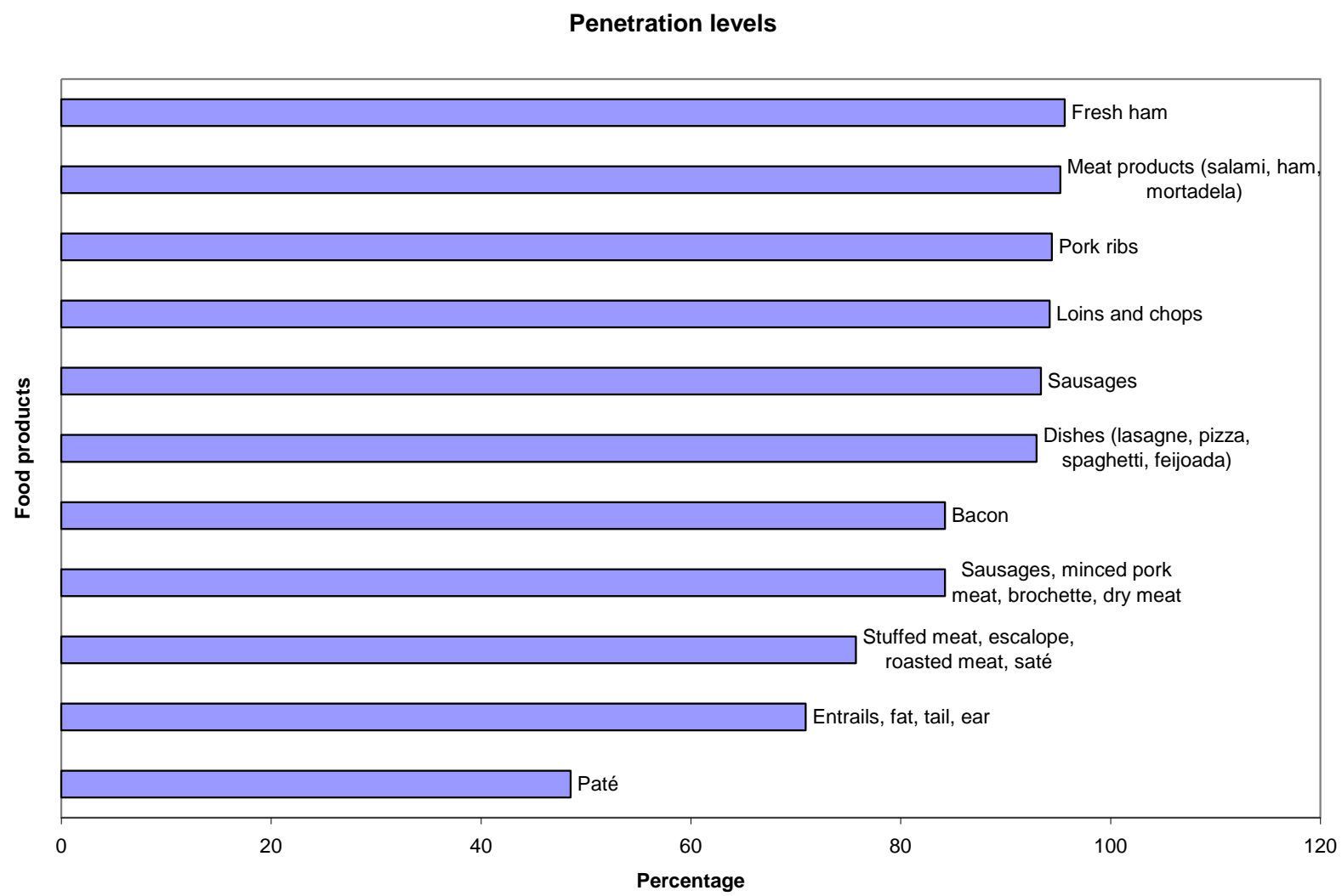

Gráfico 8 - Níveis de penetração (\%) de mercado dos produtos utilizados na pesquisa

A fim de investigar o comportamento de consumo dos respondentes, incluíram-se questões a respeito da frequência de consumo e das preferências dos consumidores, conforme expostas na Tabela 16. 
Tabela 16 - Frequência de consumo $(\%)$

\begin{tabular}{|c|c|c|c|c|c|c|c|c|}
\hline & \\
\hline & Nunca & $\begin{array}{c}\text { Uma vez } \\
\text { por ano } \\
\text { ou } \\
\text { menos } \\
\text { frequente }\end{array}$ & $\begin{array}{c}\text { Várias } \\
\text { vezes } \\
\text { ao ano }\end{array}$ & $\begin{array}{l}\text { Uma vez } \\
\text { por mês }\end{array}$ & $\begin{array}{c}\text { Várias } \\
\text { vezes por } \\
\text { mês }\end{array}$ & $\begin{array}{c}\text { Uma } \\
\text { vez por } \\
\text { semana }\end{array}$ & $\begin{array}{c}\text { Várias } \\
\text { vezes } \\
\text { por } \\
\text { semana }\end{array}$ & Diariamente \\
\hline Costela de porco & 5,6 & 29,9 & 23,7 & 19,1 & 85 & 11,6 & 0,6 & 1,0 \\
\hline Paleta, lombo, bisteca & 5,8 & 31,1 & 23,0 & 18,5 & 7,1 & 11,0 & 1,7 & 1,9 \\
\hline Pernil & 4,4 & 47,7 & 20,5 & 11,8 & 6,2 & 7,1 & 0,6 & 1,7 \\
\hline Outros (miúdos, toucinho, rabinho, orelha) & 29,0 & 33,6 & 13,7 & 10,8 & 3,5 & 8,5 & 0,4 & 0,4 \\
\hline $\begin{array}{l}\text { Salsichas, carne de porco moída, brochete, } \\
\text { carne seca }\end{array}$ & 15,5 & 34,4 & 15,4 & 12,4 & 11,4 & 7,9 & 1,7 & 1,0 \\
\hline $\begin{array}{l}\text { Carne recheada, escalope, carne assada, } \\
\text { espetinho }\end{array}$ & 24,3 & 35,9 & 12,2 & 11,4 & 8,3 & 6,0 & 0,8 & 1,0 \\
\hline Pratos (lasanha, pizza, espaguete, feijoada) & 7,1 & 21,6 & 17,8 & 19,9 & 16,4 & 14,9 & 1,7 & 0,6 \\
\hline Embutidos (salame, presunto, mortadela) & 4,8 & 7,7 & 11,8 & 12,2 & 11,8 & 22,8 & 10,2 & 18,7 \\
\hline Bacon & 15,8 & 24,1 & 12,7 & 15,8 & 10,0 & 14,7 & 3,9 & 3,1 \\
\hline Linguiças & 6,6 & 13,5 & 14,5 & 13,7 & 14,1 & 25,1 & 7,9 & 4,6 \\
\hline Patê & 51,5 & 21,4 & 6,8 & 4,6 & 5,0 & 5,8 & 2,9 & 2,1 \\
\hline
\end{tabular}

Pelos resultados, percebe-se que é bastante significativo o número de pessoas que nunca consome alguns itens de carne suína. No caso do patê, por exemplo, a quantidade de respondentes que nunca consome o produto supera a metade da amostra (51,5\%). No item outros (miúdos, toucinho), chega a 29\%, e nos mais processados (carne recheada, escalope), 24,3\% afirmaram nunca consumirem o produto.

Se forem somadas as opções 'nunca', 'uma vez por ano ou menos' e 'várias vezes ao ano', somente os itens embutidos, pratos e linguiças apresentam valores abaixo de $50 \%$ das respostas (24,3\% para embutidos, $46,5 \%$ para pratos e $34,6 \%$ para linguiças). Isso corrobora as pesquisas que afirmam que cerca de $65 \%$ do consumo de carne suína no Brasil ocorre na forma de embutidos (ROPPA, 2005). Aliás, os embutidos são o único item cuja frequência 'diariamente' aparece para uma parcela significativa da amostra (18,7\%). No entanto, ao se somarem as maiores frequências, ou seja, as opções 'diariamente', 'várias vezes por semana' e 'uma vez por 
semana', encontram-se frequências bem maiores, como 51,7\% para embutidos, seguida de 37,6\% para linguiças, $21,7 \%$ para bacon e 17,2\% para pratos (lasanha, pizza, feijoada).

Na Tabela 17 são mostrados os resultados em relação à maneira como o respondente compra os produtos.

Tabela 17 - Como você compra (\%)

\begin{tabular}{|c|c|c|c|}
\hline & Fresca & Congelada & Ambos \\
\hline Costela de porco & 88,7 & 10,3 & 1,0 \\
\hline Paleta, lombo, bisteca & 89,5 & 10,5 & 0 \\
\hline Pernil & 84,0 & 13,9 & 2,2 \\
\hline Outros (miúdos, toucinho, rabinho, orelha) & 88,3 & 11,1 & 0,6 \\
\hline $\begin{array}{l}\text { Salsichas, carne de porco moída, brochete, } \\
\text { carne seca }\end{array}$ & 88,8 & 10,8 & 0,4 \\
\hline $\begin{array}{l}\text { Carne recheada, escalope, carne assada, } \\
\text { espetinho }\end{array}$ & 84,9 & 15,1 & 0 \\
\hline Pratos (lasanha, pizza, espaguete, feijoada) & 79,9 & 20,1 & 0 \\
\hline Embutidos (salame, presunto, mortadela) & 96,4 & 3,6 & 0 \\
\hline Bacon & 93,8 & 6,2 & 0 \\
\hline Linguiças & 92,7 & 7,3 & 0 \\
\hline Patê & 93,1 & 6,9 & 0 \\
\hline
\end{tabular}

Percebe-se que a diferença entre as compras congelada e fresca são enormes, uma vez que para todos os itens a maioria dos respondentes afirma comprar $80 \%$ ou mais dos produtos frescos.

$\mathrm{Na}$ Tabela 18, os resultados apresentados referem-se ao local de compra de carne suína e confirmam a crescente participação dos supermercados como principal local de compra de alimentos (CONSOLI et al, 2010). Para todos os itens questionados, a participação dos supermercados supera a metade da amostra (de 57,6\% para costela a 89,8\% para embutidos e 96,2\% para patês). Para a opção 'outro lugar', os valores significativos $(18,9 \%$ e 14,1\%) aparecem respectivamente para 'pratos' como lasanha, pizza ou feijoada, e 'carne recheada, escalope, espetinho', que são, pela própria natureza, mais consumidos em restaurantes. 
Tabela 18 - Onde você compra $(\%)$

\begin{tabular}{|c|c|c|c|}
\hline & \\
\hline & \multicolumn{3}{|c|}{ No } \\
\hline & No açougue & supermercado & Outro lugar \\
\hline Costela de porco & 41,2 & 57,6 & 1,3 \\
\hline Paleta, lombo, bisteca & 45,7 & 52,6 & 1,6 \\
\hline Pernil & 32,5 & 65,4 & 2,2 \\
\hline Outros (miúdos, toucinho, rabinho, orelha) & 37,8 & 58,3 & 3,9 \\
\hline Salsichas, carne de porco moída, brochete, carne seca & 19,6 & 78,8 & 1,7 \\
\hline Carne recheada, escalope, carne assada, espetinho & 20,3 & 65,6 & 14,1 \\
\hline Pratos (lasanha, pizza, espaguete, feijoada) & 5,2 & 75,9 & 18,9 \\
\hline Embutidos (salame, presunto, mortadela) & 8,1 & 89,8 & 2,1 \\
\hline Bacon & 20,0 & 79,3 & 0,7 \\
\hline Linguiças & 19,0 & 80,3 & 0,8 \\
\hline Patê & 3,8 & 96,2 & 0 \\
\hline
\end{tabular}

Na Tabela 19 apresentam-se os resultados da questão sobre a ocasião de consumo dos produtos de carne suína.

Tabela 19 - Quando você consome $(\%)$

\begin{tabular}{|c|c|c|c|c|}
\hline & \\
\hline & $\begin{array}{l}\text { Em dia de } \\
\text { semana }\end{array}$ & $\begin{array}{l}\text { Qualquer } \\
\text { dia }\end{array}$ & $\begin{array}{l}\text { Nos finais } \\
\text { de semana }\end{array}$ & $\begin{array}{c}\text { Somente em } \\
\text { ocasiões especiais }\end{array}$ \\
\hline Costela de porco & 17,0 & 57,2 & 20,9 & 4,8 \\
\hline Paleta, lombo, bisteca & 11,5 & 67,1 & 15,1 & 6,3 \\
\hline Pernil & 9,1 & 50,2 & 23,4 & 17,3 \\
\hline Outros (miúdos, toucinho, rabinho, orelha) & 10,0 & 75,6 & 13,9 & 0,6 \\
\hline Salsichas, carne de porco moída, brochete, carne seca & 10,0 & 65,4 & 21,3 & 3,3 \\
\hline Carne recheada, escalope, carne assada, espetinho & 8,9 & 46,9 & 32,3 & 12,0 \\
\hline
\end{tabular}




\begin{tabular}{lcccc} 
Pratos (lasanha, pizza, espaguete, feijoada) & 8,1 & 40,4 & 48,3 & 3,2 \\
Embutidos (salame, presunto, mortadela) & 6,4 & 87,9 & 4,7 & 0,9 \\
Bacon & 7,2 & 80,0 & 11,0 & 1,7 \\
Linguiças & 6,5 & 85,2 & 7,3 & 1,0 \\
Patê & 11,5 & 77,1 & 11,5 & 0 \\
\hline
\end{tabular}

Os resultados demonstram que os itens são, em sua maioria, consumidos principalmente em 'qualquer dia'. O produto 'pernil' apresenta o maior consumo 'em ocasiões especiais' entre todos os itens $(17,3 \%)$, seguido dos mais processados, como 'carne recheada, escalope, carne assada e espetinho' (12\%). Esse resultado era esperado, já que pelo próprio tamanho e por ser tradicionalmente preparado de maneira mais lenta, o pernil costuma ser consumido em ocasiões especiais, principalmente nas festas de final de ano, como o Natal e Ano Novo, quando se reúne uma grande quantidade de pessoas.

Já os pratos, como lasanha, pizza, espaguete e feijoada, e também os mais processados, são os que aparecem com mais frequência como consumidos nos finais de semana (48,3 e 32,3\% respectivamente). As massas são tradicionais refeições de domingo no Brasil, principalmente nas famílias de descendência italiana (e aí estão incluídos a lasanha e o espaguete), a feijoada é tradicionalmente um item consumido aos sábados, como prato único, e a pizza é um programa 'de domingo' para grande parte da população urbana no Brasil.

Na Tabela 20, demonstram-se os resultados da questão a respeito da companhia na qual os respondentes consomem os itens de carne suína. Nos resultados, percebe-se que a maioria dos respondentes consome os alimentos com a família, e o único item em que o consumo 'com a família' é menor que 70\% é 'pratos', que inclui pizza (tradicionalmente consumida em pizzarias, e, portanto, onde amigos costumam encontrar-se) e feijoada, um prato bastante escolhido para confraternizações e eventos entre amigos. O item com nível de consumo mais significante 'sozinho' é o ‘embutidos', que, pelas próprias características é bastante compreensível, já que os embutidos são comumente inseridos em sanduíches e outros alimentos consumidos rapidamente e fora de casa. 
Tabela 20 - Com quem (\%)

\begin{tabular}{lcccc} 
& Sozinho & $\begin{array}{c}\text { Com a } \\
\text { família }\end{array}$ & $\begin{array}{c}\text { Com } \\
\text { amigos }\end{array}$ & Com outros \\
\hline Costela de porco & 6,4 & 89,4 & 4,2 & 0 \\
Paleta, lombo, Bbisteca & 5,9 & 87,2 & 6,9 & 0 \\
Pernil & 5,6 & 84,8 & 9,1 & 0,6 \\
Outros (miúdos, toucinho, rabinho, orelha) & 6,7 & 85,0 & 7,8 & 0 \\
\hline Salsichas, carne de porco moída, brochete, carne seca & 5,8 & 82,9 & 11,3 & 0 \\
Carne recheada, escalope, carne assada, espetinho & 7,8 & 73,4 & 18,8 & 0,6 \\
Pratos (lasanha, pizza, espaguete, feijoada) & 4,1 & 64,2 & 31,1 & 0 \\
Embutidos (salame, presunto, mortadela) & 18,0 & 78,7 & 3,3 & 0,3 \\
\hline Bacon & 11,7 & 85,2 & 2,8 & 0 \\
\hline Linguiças & 12,5 & 84,9 & 2,6 & 0 \\
\hline Patê & 16,0 & 82,4 & 1,5 & \\
\hline
\end{tabular}

A Tabela 21 apresenta os resultados da questão sobre onde se consomem os alimentos à base de carne suína. Pelas próprias características da amostra, que incluiu cidades bem próximas ao ambiente rural e capitais de porte médio, onde os níveis de refeições fora do lar são baixos e ainda é costume que as pessoas façam suas refeições em casa, a prevalência de respostas 'em casa' é bastante grande, chegando a 98,5\% para patês, e 95,9\% para bacon. Novamente, os itens mais consumidos em restaurantes $(21,4 \%$ e $18,9 \%)$ são 'carne recheada, escalope, espetinho’ ou os mais processados, e os 'pratos' (pizza e feijoada). 
Tabela 21 - Onde você come (\%)

\begin{tabular}{lcccc} 
& Em casa & $\begin{array}{c}\text { Em um } \\
\text { restaurante }\end{array}$ & No caminho & $\begin{array}{c}\text { Algum outro } \\
\text { lugar }\end{array}$ \\
\cline { 2 - 5 } Costela de porco & 91,3 & 7,1 & 0,6 & 1,0 \\
Paleta, lombo, bisteca & 91,4 & 6,3 & 0 & 2,3 \\
Pernil & 87,4 & 7,8 & 0,4 & 4,3 \\
Outros (miúdos, toucinho, rabinho, orelha) & 85,6 & 12,2 & 0,6 & 1,7 \\
Salsichas, carne de porco moída, brochete, carne seca & 82,9 & 12,9 & 2,9 & 1,3 \\
Carne recheada, escalope, carne assada, espetinho & 68,2 & 21,4 & 7,3 & 3,1 \\
Pratos (lasanha, pizza, espaguete, feijoada) & 61,9 & 18,9 & 9,6 & 9,6 \\
Embutidos (salame, presunto, mortadela) & 94,5 & 4,7 & 0 & 0,7 \\
\hline Bacon & 95,9 & 3,4 & 0 & 0,7 \\
\hline Linguiças & 93,8 & 5,2 & 0,3 & 0,8 \\
\hline Patê & 98,5 & 1,5 & 0 & 0 \\
\hline
\end{tabular}

Na Tabela 22, onde são demonstradas as respostas referentes ao grau de preparação do alimento em casa, percebe-se que os embutidos e os patês, logicamente, são comprados 'prontos para comer', mas que a maior parte dos itens, especialmente os cortes frescos como costela $(80,1 \%)$, paleta, lombo e bisteca $(81,6 \%)$ ou pernil $(75,3 \%)$, são principalmente 'preparados em casa desde o início'. No item pratos, há uma boa distribuição entre os graus de preparo, sendo 39,2\% 'preparada em casa desde o início', 25,9\% 'finalizada em casa antes de comer' e 34,9\% 'comprada pronta para comer'. 
Tabela 22 - Quanto de preparo (\%)

\begin{tabular}{lcc|c} 
& $\begin{array}{c}\text { É preparada em } \\
\text { casa desde o } \\
\text { início }\end{array}$ & $\begin{array}{c}\text { É finalizada } \\
\text { em casa antes } \\
\text { de comer }\end{array}$ & $\begin{array}{c}\text { É comprada } \\
\text { pronta pra } \\
\text { comer }\end{array}$ \\
\hline Costela de porco & 80,1 & 16,7 & 3,2 \\
\hline Paleta, lombo, bisteca & 81,6 & 16,1 & 2,3 \\
\hline Pernil & 75,3 & 21,2 & 3,5 \\
\hline Outros (miúdos, toucinho, rabinho, orelha) & 66,7 & 30,0 & 3,3 \\
\hline Salsichas, carne de porco moída, brochete, carne seca & 62,1 & 23,8 & 14,2 \\
\hline Carne recheada, escalope, carne assada, espetinho & 50,5 & 33,3 & 16,1 \\
\hline Pratos (lasanha, pizza, espaguete, feijoada) & 39,2 & 25,9 & 34,9 \\
\hline Embutidos (salame, presunto, mortadela) & 26,8 & 18,2 & 55,0 \\
\hline Bacon & 46,2 & 27,2 & 26,6 \\
\hline Linguiças & 43,1 & 27,0 & 29,9 \\
\hline Patê & 24,4 & 19,1 & 56,5 \\
\hline
\end{tabular}

Demonstra-se, assim, que quanto mais processado o produto, menor seu preparo pelo consumidor e, ao contrário, quanto menos processado, maior o preparo pelo consumidor de carne suína.

\subsubsection{Frequência de consumo dos itens frescos e processados}

Apesar de estarem separados em 11 produtos diferentes, optou-se por dividir os alimentos utilizados na pesquisa em 'frescos' e 'processados', ao invés da separação inicialmente proposta no desenvolvimento do questionário. Assim, os itens 1 (costela de porco), 2 (paleta, lombo, bisteca), 3 (pernil) e 4 (outros - miúdos, toucinho, rabo, orelha) foram classificados como 'frescos', os itens 5 (linguiças, salsichão, carne embalada a vácuo, carne moída), 6 (carne recheada, escalope, carne assada, espetinho), 7 (lasanha, pizza, macarronada, feijoada) e 8.1 (frios - salame, presunto, mortadela) foram classificados como 'processados', e os itens 8.2 
(bacon, que tem baixo consumo), 8.3 (salsichas e linguiças, que apareciam novamente), e 8.4 (patês, que também têm o consumo muito baixo) foram excluídos da análise por apresentarem níveis muito baixos de consumo.

Nesta nova análise, o índice KMO obtido foi de 0,770, e o teste de esfericidade de Bartlett rejeita a hipótese nula. A variância total explicada foi de 55,204\% no segundo fator.

A tabela 23 mostra a carga fatorial (correlação que cada variável tem com seu fator) e seus alfa de Cronbach.

Tabela 23 - Análise fatorial da frequência de consumo dos itens frescos e processados e seus alfas de Cronbach

\begin{tabular}{ccc}
\hline & Frescos & Processados \\
\hline Nunca & $\mathbf{0 , 8 4 0}$ & \\
\hline Uma vez por ano ou menos & 0,801 & \\
Muitas vezes por ano & 0,799 & \\
Uma vez por mês & 0,666 & 0,696 \\
Muitas vezes por mês & & $\mathbf{0 , 7 3 3}$ \\
Uma vez por semana & & 0,711 \\
Muitas vezes por semana & & 0,532 \\
Diariamente & 0,8 & 0,6 \\
\hline Alfa de Cronbach & & \\
\hline
\end{tabular}

Notas: Método de extração: Análise de componente principal. Método de rotação: Varimax com normalização Kaiser. A rotação convergiu em três interações.

Alguns resultados interessantes podem ser observados, como o alto valor obtido para respondentes que Nunca consomem produtos frescos $(\mathbf{0 , 8 4 0})$, bem como os respondentes que consomem produtos processados Uma vez por semana $(\mathbf{0 , 7 3 3})$. Uma das explicações pode residir no fato de que grande parte dos entrevistados afirmaram consumir muito pouco de produtos frescos, geralmente encontrados em grandes cortes, e quanto aos processados, há grande parte da amostra que afirma consumir embutidos diariamente, o que deve ter influenciado os resultados. 


\subsubsection{Satisfação}

Quanto à satisfação em relação aos produtos, os resultados demonstram que em geral todos os itens apresentam bons níveis de satisfação geral e sabor, confirmando pesquisas que afirmam que a carne suína é considerada mais saborosa pelo consumidor, entre as mais consumidas (carne bovina, suína e de frango) (ROJO, 1994). O preço é o item que apresenta níveis mais baixos de satisfação do consumidor, demonstrando que a carne ainda é considerada um produto caro na cesta de consumo dos brasileiros. Confirmam-se aqui os resultados encontrados em Belo Horizonte por Faria et al (2006).

A seguir apresentam-se as estatísticas descritivas da satisfação dos respondentes em relação a cada um dos produtos pesquisados. As estatísticas descritivas incluem medidas de tendência central (médias, mediana e moda) e medidas de variabilidade em torno da média (escala e desvio padrão). Elas oferecem ao leitor uma visão geral, ou uma "fotografia" dos dados coletados e usados na pesquisa. A Tabela 24 apresenta as médias e desvio padrão do item em questão. 
Tabela 24 - Percepção de qualidade e níveis de satisfação por produto

\begin{tabular}{|c|c|c|c|c|c|c|c|c|c|c|}
\hline & \multicolumn{2}{|c|}{$\underline{\text { Geral }}$} & \multicolumn{2}{|c|}{$\underline{\text { Sabor }}$} & \multicolumn{2}{|c|}{$\underline{\text { Saúde }}$} & \multicolumn{2}{|c|}{$\underline{\text { Conveniência }}$} & \multicolumn{2}{|c|}{$\underline{\text { Preço }}$} \\
\hline & Média & DP & Média & $\mathrm{DP}$ & Média & DP & Média & $\mathrm{DP}$ & Média & DP \\
\hline Costela de porco & 6,0 & 1,1 & 6,2 & 1,0 & 5,1 & 2,0 & 5.6 & 1.4 & 4.1 & 1.9 \\
\hline Paleta, lombo, bisteca & 5,9 & 1,1 & 6,2 & 1,1 & 5,1 & 1,9 & 5.7 & 1.4 & 4.1 & 2.0 \\
\hline Pernil & 6,0 & 1,1 & 6,2 & 1,1 & 5,1 & 2,0 & 5.7 & 1.6 & 3.9 & 2.1 \\
\hline Outros (miúdos, toucinho, rabinho, orelha) & 5,8 & 1,2 & 6,1 & 1,1 & 4,5 & 2,3 & 5.5 & 1.5 & 4.2 & 2.2 \\
\hline Salsicha, carne de porco moída, brochete, carne seca & 5,9 & 1,1 & 5,9 & 1,2 & 5,3 & 1,8 & 5.8 & 1.3 & 4.3 & 1.8 \\
\hline Carne recheada, escalope, carne assada, espetinho & 6,0 & 1,2 & 6,1 & 1,1 & 5,3 & 1,7 & 5.5 & 1.6 & 4.0 & 1.9 \\
\hline Lasanha, pizza, espaguete, feijoada & 6,0 & 1,1 & 6,4 & 1,0 & 5,4 & 1,7 & 5.9 & 1.4 & 4.4 & 2.0 \\
\hline Embutidos (salame, presunto, mortadela) & 6,0 & 1,1 & 6,1 & 1,1 & 5,2 & 1,9 & 6.1 & 1.2 & 4.4 & 2.0 \\
\hline Bacon & 5,9 & 1,2 & 6,0 & 1,2 & 4,9 & 2,1 & 6.0 & 1.2 & 4.2 & 2.2 \\
\hline Linguiças & 6,0 & 1,2 & 6,1 & 1,1 & 5,1 & 2,0 & 6.1 & 1.2 & 4.6 & 2.0 \\
\hline Patê & 6,1 & 1,0 & 6,1 & 1,1 & 5,7 & 1,4 & 6.3 & 1.0 & 5.2 & 1.7 \\
\hline
\end{tabular}


Realizou-se em seguida a divisão por cidades, para verificar a existência ou não de diferenças entre elas. Primeiramente efetuou-se uma análise fatorial às variáveis que compõem a dimensão "primeiros cortes frescos", com o objetivo de verificar se poderiam ser agrupadas em apenas uma variável. Observou-se que a correlação entre as variáveis é alta, tornando o agrupamento adequado. A variável condensada "produtos frescos" foi calculada pela média aritmética entre as variáveis originais (costela de porco, paleta/lombo/bisteca, pernil, outros). O mesmo procedimento foi aplicado à dimensão "produtos de carne", sendo a variável condensada, a média aritmética entre as variáveis: frios, bacon, salsichas/linguiças, patê.

\subsubsection{Satisfação geral}

A Tabela 25, a seguir, apresenta as estatísticas descritivas de cada dimensão por cidade, em relação à satisfação geral com os produtos.

Tabela 25 - Estatísticas descritivas de cada dimensão por cidade

\begin{tabular}{|c|c|c|c|c|c|c|}
\hline \multicolumn{7}{|c|}{ Satisfação Geral } \\
\hline \multicolumn{2}{|l|}{ Cidade } & $\begin{array}{c}\text { Produtos } \\
\text { Frescos }\end{array}$ & $\begin{array}{c}\text { Frescos } \\
\text { Pouco } \\
\text { Processados }\end{array}$ & $\begin{array}{c}\text { Mais } \\
\text { Processados }\end{array}$ & Refeições & $\begin{array}{c}\text { Produtos } \\
\text { de } \\
\text { Carne }\end{array}$ \\
\hline \multirow{3}{*}{$\begin{array}{l}\text { Porto } \\
\text { Alegre }\end{array}$} & Média & 5,89 & 5,47 & 5,39 & 6,08 & 5,86 \\
\hline & $\begin{array}{l}\text { Desvio } \\
\text { padrão }\end{array}$ & 0,76 & 0,84 & 0,69 & 0,62 & 0,89 \\
\hline & $\begin{array}{l}\text { Coef. } \\
\text { Variação }\end{array}$ & $13 \%$ & $15 \%$ & $13 \%$ & $10 \%$ & $15 \%$ \\
\hline \multirow{3}{*}{$\begin{array}{l}\text { Santa } \\
\text { Rosa }\end{array}$} & Média & 6,50 & 6,46 & 6,91 & 6,69 & 6,64 \\
\hline & $\begin{array}{l}\text { Desvio } \\
\text { padrão }\end{array}$ & 0,81 & 0,72 & 0,29 & 0,58 & 0,61 \\
\hline & $\begin{array}{l}\text { Coef. } \\
\text { Variação }\end{array}$ & $12 \%$ & $11 \%$ & $4 \%$ & $9 \%$ & $9 \%$ \\
\hline \multirow[t]{3}{*}{ Curitiba } & Média & 5,89 & 5,56 & 5,79 & 6,25 & 5,68 \\
\hline & $\begin{array}{l}\text { Desvio } \\
\text { padrão }\end{array}$ & 1,09 & 1,37 & 1,22 & 1,00 & 1,20 \\
\hline & $\begin{array}{l}\text { Coef. } \\
\text { Variação }\end{array}$ & $19 \%$ & $25 \%$ & $21 \%$ & $16 \%$ & $21 \%$ \\
\hline Ponta & Média & 5,98 & 6,06 & 5,80 & 6,06 & 5,91 \\
\hline
\end{tabular}




\begin{tabular}{|c|c|c|c|c|c|c|}
\hline \multirow[t]{2}{*}{ Grossa } & $\begin{array}{l}\text { Desvio } \\
\text { padrão }\end{array}$ & 0,98 & 0,77 & 1,23 & 0,84 & 0,92 \\
\hline & \begin{tabular}{|l|} 
Coef. \\
Variação
\end{tabular} & $16 \%$ & $13 \%$ & $21 \%$ & $14 \%$ & $16 \%$ \\
\hline \multirow[t]{3}{*}{ Cuiabá } & Média & 5,39 & 5,61 & 5,65 & 5,72 & 5,82 \\
\hline & $\begin{array}{l}\text { Desvio } \\
\text { padrão }\end{array}$ & 1,28 & 1,53 & 1,50 & 1,43 & 1,20 \\
\hline & \begin{tabular}{|l|} 
Coef. \\
Variação
\end{tabular} & $24 \%$ & $27 \%$ & $26 \%$ & $25 \%$ & $21 \%$ \\
\hline \multirow{3}{*}{$\begin{array}{l}\text { Campo } \\
\text { Verde }\end{array}$} & Média & 5,55 & 6,27 & 6,18 & 5,48 & 5,65 \\
\hline & $\begin{array}{l}\text { Desvio } \\
\text { padrão }\end{array}$ & 1,17 & 0,90 & 1,25 & 1,09 & 0,94 \\
\hline & \begin{tabular}{|l|} 
Coef. \\
Variação
\end{tabular} & $21 \%$ & $14 \%$ & $20 \%$ & $20 \%$ & $17 \%$ \\
\hline \multirow[t]{3}{*}{ Goiânia } & Média & 5,86 & 5,74 & 6,00 & 6,34 & 6,15 \\
\hline & $\begin{array}{l}\text { Desvio } \\
\text { padrão }\end{array}$ & 1,08 & 1,06 & 0,73 & 0,72 & 1,15 \\
\hline & $\begin{array}{l}\text { Coef. } \\
\text { Variação }\end{array}$ & $18 \%$ & $19 \%$ & $12 \%$ & $11 \%$ & $19 \%$ \\
\hline \multirow{3}{*}{$\begin{array}{c}\text { Rio } \\
\text { Verde }\end{array}$} & Média & 6,08 & 6,15 & 5,95 & 5,90 & 5,97 \\
\hline & $\begin{array}{l}\text { Desvio } \\
\text { padrão }\end{array}$ & 1,24 & 0,88 & 1,32 & 1,35 & 1,31 \\
\hline & $\begin{array}{l}\text { Coef. } \\
\text { Variação }\end{array}$ & $20 \%$ & $14 \%$ & $22 \%$ & $23 \%$ & $22 \%$ \\
\hline
\end{tabular}

Aplicou-se o teste de Kruskall Wallis (teste não paramétrico de análise de variância usado para comparar as médias de diferentes grupos, sendo os dados substituídos por suas posições ou postos) para verificar a existência de diferença significativa de satisfação entre as cidades estudadas nas diferentes dimensões de produtos. $\mathrm{O}$ teste indicou que há diferença significativa para pelo menos um par de cidades em todas as categorias de produtos ( $\mathrm{p}$-valor frescos $=0,000$; $\mathrm{p}$-valor pouco processados $=0,001 ; \mathrm{p}$-valor mais processados $=0,000$; $\mathrm{p}$-valor refeições $=0,000$, p-valor carne $=0,000$ ). A Tabela 26 , a seguir, apresenta as cidades com diferença significativa de satisfação geral, considerando 5\% de significância. 
Tabela 26 - Cidades com diferenças significativas de satisfação geral

\begin{tabular}{|c|c|c|c|c|c|}
\hline Combinação & Frescos & Pouco Proc. & Mais Proc. & Refeição & Prod.Carne \\
\hline $\begin{array}{l}\text { Porto Alegre X Santa } \\
\text { Rosa }\end{array}$ & $\mathrm{SR}>\mathrm{PA}$ & $\mathrm{SR}>\mathrm{PA}$ & $\mathrm{SR}>\mathrm{PA}$ & $\mathrm{SR}>\mathrm{PA}$ & $\mathrm{SR}>\mathrm{PA}$ \\
\hline \multicolumn{6}{|l|}{ Porto Alegre X Curitiba } \\
\hline $\begin{array}{l}\text { Porto Alegre X Ponta } \\
\text { Grossa }\end{array}$ & & PG>PA & & & \\
\hline Porto Alegre X Cuiabá & $\mathrm{PA}>\mathrm{CB}$ & & & & \\
\hline $\begin{array}{l}\text { Porto Alegre X Campo } \\
\text { Verde }\end{array}$ & & $\mathrm{CV}>\mathrm{PA}$ & $\mathrm{CV}>\mathrm{PA}$ & $\mathrm{CV}>\mathrm{PA}$ & \\
\hline \multicolumn{6}{|l|}{ Porto Alegre X Goiânia } \\
\hline $\begin{array}{llll}\text { Porto } & \text { Alegre } & X & \text { Rio } \\
\text { Verde } & & & \\
\end{array}$ & & $\mathrm{RV}>\mathrm{PA}$ & & & \\
\hline Santa Rosa X Curitiba & $\mathrm{SR}>\mathrm{CR}$ & $\mathrm{SR}>\mathrm{CR}$ & $\mathrm{SR}>\mathrm{CR}$ & $\mathrm{SR}>\mathrm{CR}$ & $\mathrm{SR}>\mathrm{CR}$ \\
\hline $\begin{array}{llll}\text { Santa Rosa } & \text { X } & \text { Ponta } \\
\text { Grossa } & & & \\
\end{array}$ & $\mathrm{SR}>\mathrm{PG}$ & & $\mathrm{SR}>\mathrm{PG}$ & $\mathrm{SR}>\mathrm{PG}$ & $\mathrm{SR}>\mathrm{PG}$ \\
\hline Santa Rosa X Cuiabá & $\mathrm{SR}>\mathrm{CB}$ & $\mathrm{SR}>\mathrm{CB}$ & $\mathrm{SR}>\mathrm{CB}$ & $\mathrm{SR}>\mathrm{CB}$ & $\mathrm{SR}>\mathrm{CB}$ \\
\hline $\begin{array}{l}\text { Santa Rosa X Campo } \\
\text { Verde }\end{array}$ & $\mathrm{SR}>\mathrm{CV}$ & & & $\mathrm{SR}>\mathrm{CV}$ & $\mathrm{SR}>\mathrm{CV}$ \\
\hline Santa Rosa X Goiânia & SR>GN & SR>GN & SR>GN & & SR>GN \\
\hline Santa Rosa X Rio Verde & $\mathrm{SR}>\mathrm{RV}$ & & $\mathrm{SR}>\mathrm{RV}$ & SR>RV & SR>RV \\
\hline \multicolumn{6}{|l|}{ Curitiba X Ponta Grossa } \\
\hline Curitiba X Cuiabá & $\mathrm{CR}>\mathrm{CB}$ & & & $\mathrm{CR}>\mathrm{CB}$ & \\
\hline Curitiba X Campo Verde & & & & $\mathrm{CR}>\mathrm{CV}$ & \\
\hline Curitiba X Goiânia & & & & & $\mathrm{GN}>\mathrm{CR}$ \\
\hline Curitiba X Rio Verde & & $\mathrm{RV}>\mathrm{CR}$ & & & \\
\hline Ponta Grossa X Cuiabá & $\mathrm{PG}>\mathrm{CB}$ & & & & \\
\hline $\begin{array}{l}\text { Ponta Grossa X Campo } \\
\text { Verde }\end{array}$ & & & & $\mathrm{PG}>\mathrm{CV}$ & \\
\hline \multicolumn{6}{|l|}{ Ponta Grossa X Goiânia } \\
\hline \multicolumn{6}{|l|}{$\begin{array}{llll}\text { Ponta } & \text { Grossa } & \text { X } & \text { Rio } \\
\text { Verde } & & & \end{array}$} \\
\hline \multicolumn{6}{|l|}{ Cuiabá X Campo Verde } \\
\hline Cuiabá X Goiânia & $\mathrm{GN}>\mathrm{CB}$ & & & $\mathrm{CN}>\mathrm{CB}$ & \\
\hline Cuiabá X Rio Verde & $\mathrm{RV}>\mathrm{CB}$ & $\mathrm{RV}>\mathrm{CB}$ & & & \\
\hline Campo Verde X Goiânia & & & & $\mathrm{GN}>\mathrm{CV}$ & $\mathrm{GN}>\mathrm{CV}$ \\
\hline $\begin{array}{llll}\text { Campo Verde X Rio } \\
\text { Verde }\end{array}$ & $\mathrm{RV}>\mathrm{CV}$ & & & & \\
\hline Goiânia X Rio Verde & & & & & \\
\hline
\end{tabular}

Assim, percebe-se que, comparando os resultados de Porto Alegre e Santa Rosa, os respondentes de Santa Rosa apresentam maior satisfação geral que os de Porto Alegre em relação a todos os produtos. Comparando Porto Alegre e Ponta Grossa, encontrou-se diferença significativa de satisfação somente em relação aos produtos pouco processados, sendo a satisfação dos respondentes de Ponta Grossa maior que a daqueles de Porto Alegre.

Comparando Porto Alegre e Cuiabá, percebe-se que os respondentes de Porto Alegre estão significativamente mais satisfeitos do que os de Cuiabá apenas no item produtos frescos. Entre 
Porto Alegre e Campo Verde, os respondentes de Campo Verde apresentam maior satisfação geral do que os de Porto Alegre com os produtos pouco processados, mais processados e refeições.

Na comparação entre Porto Alegre e Rio Verde, os respondentes de Rio Verde apresentam satisfação significativamente maior apenas com relação aos produtos pouco processados.

Já entre Santa Rosa e Curitiba, os respondentes de Santa Rosa apresentam maior satisfação geral que Curitiba em relação a todos os produtos, o mesmo acontece na comparação entre Santa Rosa e Cuiabá. Comparando Santa Rosa e Ponta Grossa, não há diferença significativa apenas em relação aos produtos pouco processados, e Santa Rosa apresenta novamente maior satisfação geral. O mesmo acontece na comparação entre Santa Rosa e Rio Verde. Entre Santa Rosa e Campo Verde, Santa Rosa só não apresenta satisfação significativamente maior nos produtos pouco processados e mais processados; e entre Santa Rosa e Goiânia, apenas não há diferença significativamente maior a favor de Santa Rosa em relação ao item refeições.

Comparando Curitiba e Cuiabá, encontrou-se diferença significativa entre os produtos frescos e refeições, sendo os respondentes de Curitiba mais satisfeitos de maneira geral com os produtos de carne suína do que os de Cuiabá. Os respondentes de Curitiba apresentam maior satisfação geral que os de Campo Verde no item refeições, que os de Goiânia no item produtos de carne e que os de Rio Verde nos produtos pouco processados.

Já Ponta Grossa apresenta maior satisfação geral do que Cuiabá nos produtos frescos, e do que Campo Verde no item refeições. Comparando Cuiabá com as outras cidades, percebe-se diferença significativa com Goiânia nos itens frescos e refeições, sendo os respondentes de Goiânia mais satisfeitos de maneira geral que os de Cuiabá nos dois itens. Cuiabá também perde em satisfação para os respondentes de Rio Verde nos itens frescos e pouco processados.

Entre Goiânia e Campo Verde, há diferença significativa nos itens refeições e produtos de carne, sendo os respondentes de Goiânia mais satisfeitos. Finalmente, na comparação entre Rio Verde e Campo Verde, há diferença significativa nos produtos frescos, sendo maior a satisfação dos respondentes de Rio Verde. 


\subsubsection{Satisfação com o sabor}

Em relação à satisfação com o sabor, têm-se as estatísticas descritivas apresentadas na Tabela 27, a seguir, para as cidades do estudo.

Tabela 27 - Estatísticas descritivas da satisfação com o sabor para as cidades do estudo

\begin{tabular}{|c|c|c|c|c|c|c|}
\hline \multicolumn{7}{|c|}{ Satisfação com Sabor } \\
\hline \multicolumn{2}{|l|}{ Cidade } & $\begin{array}{c}\text { Produtos } \\
\text { Frescos }\end{array}$ & $\begin{array}{c}\text { Frescos } \\
\text { Pouco } \\
\text { Processados }\end{array}$ & $\begin{array}{c}\text { Mais } \\
\text { Processados }\end{array}$ & Refeições & $\begin{array}{c}\text { Produtos } \\
\text { Carne }\end{array}$ \\
\hline \multirow{3}{*}{$\begin{array}{c}\text { Porto } \\
\text { Alegre }\end{array}$} & Média & 6,10 & 5,66 & 5,79 & 6,44 & 6,11 \\
\hline & $\begin{array}{l}\text { Desvio } \\
\text { padrão }\end{array}$ & 0,69 & 0,87 & 0,69 & 0,68 & 0,65 \\
\hline & $\begin{array}{l}\text { Coef. } \\
\text { Variação }\end{array}$ & $11 \%$ & $15 \%$ & $12 \%$ & $11 \%$ & $11 \%$ \\
\hline \multirow{3}{*}{$\begin{array}{l}\text { Santa } \\
\text { Rosa }\end{array}$} & Média & 6,61 & 6,41 & 6,85 & 6,78 & 6,62 \\
\hline & $\begin{array}{l}\text { Desvio } \\
\text { padrão }\end{array}$ & 0,77 & 0,82 & 0,36 & 0,48 & 0,66 \\
\hline & $\begin{array}{l}\text { Coef. } \\
\text { Variação }\end{array}$ & $12 \%$ & $13 \%$ & $5 \%$ & $7 \%$ & $10 \%$ \\
\hline \multirow[t]{3}{*}{ Curitiba } & Média & 6,32 & 6,03 & 6,41 & 6,44 & 5,64 \\
\hline & $\begin{array}{l}\text { Desvio } \\
\text { padrão }\end{array}$ & 1,06 & 1,26 & ,91 & 1,07 & 1,31 \\
\hline & $\begin{array}{l}\text { Coef. } \\
\text { Variação }\end{array}$ & $17 \%$ & $21 \%$ & $14 \%$ & $17 \%$ & $23 \%$ \\
\hline \multirow{3}{*}{$\begin{array}{l}\text { Ponta } \\
\text { Grossa }\end{array}$} & Média & 6,05 & 6,06 & 6,00 & 6,40 & 5,92 \\
\hline & $\begin{array}{l}\text { Desvio } \\
\text { padrão }\end{array}$ & 0,88 & 1,09 & 1,05 & 0,68 & 1,02 \\
\hline & $\begin{array}{l}\text { Coef. } \\
\text { Variação }\end{array}$ & $14 \%$ & $18 \%$ & $18 \%$ & $11 \%$ & $17 \%$ \\
\hline \multirow[t]{3}{*}{ Cuiabá } & Média & 6,33 & 5,03 & 5,65 & 6,26 & 5,88 \\
\hline & $\begin{array}{l}\text { Desvio } \\
\text { padrão }\end{array}$ & 1,02 & 1,40 & 1,45 & 1,23 & 1,14 \\
\hline & $\begin{array}{l}\text { Coef. } \\
\text { Variação }\end{array}$ & $16 \%$ & $28 \%$ & $26 \%$ & $20 \%$ & $19 \%$ \\
\hline \multirow{3}{*}{$\begin{array}{l}\text { Campo } \\
\text { Verde }\end{array}$} & Média & 5,57 & 5,64 & 5,73 & 5,96 & 5,77 \\
\hline & $\begin{array}{l}\text { Desvio } \\
\text { padrão }\end{array}$ & 1,27 & 1,36 & 1,68 & 1,10 & 0,99 \\
\hline & $\begin{array}{l}\text { Coef. } \\
\text { Variação }\end{array}$ & $23 \%$ & $24 \%$ & $29 \%$ & $18 \%$ & $17 \%$ \\
\hline \multirow[t]{2}{*}{ Goiânia } & Média & 5,99 & 6,03 & 5,94 & 6,55 & 6,54 \\
\hline & $\begin{array}{l}\text { Desvio } \\
\text { padrão }\end{array}$ & 1,29 & 0,91 & 0,93 & 0,87 & 0,79 \\
\hline
\end{tabular}




\begin{tabular}{c|l|r|r|r|r|r|} 
& $\begin{array}{l}\text { Coef. } \\
\text { Variação }\end{array}$ & $21 \%$ & $15 \%$ & $16 \%$ & $13 \%$ & $12 \%$ \\
\hline \multirow{2}{*}{ Rio } & Média & 6,18 & 6,35 & 6,29 & 6,23 & 6,14 \\
\cline { 2 - 7 } & $\begin{array}{l}\text { Desvio } \\
\text { padrão }\end{array}$ & 1,15 & 0,89 & 0,72 & 0,97 & 1,17 \\
\cline { 2 - 7 } & $\begin{array}{l}\text { Coef. } \\
\text { Variação }\end{array}$ & $19 \%$ & $14 \%$ & $11 \%$ & $16 \%$ & $19 \%$ \\
\hline
\end{tabular}

Aplicou-se novamente o teste de Kruskall Wallis para verificar a existência de diferença significativa de satisfação entre as cidades estudadas nas diferentes dimensões de produtos. $\mathrm{O}$ teste indicou que há diferença significativa para pelo menos um par de cidades em todas as categorias de produtos ( $\mathrm{p}$-valor frescos $=0,000 ; \mathrm{p}$-valor pouco processados $=0,000 ; \mathrm{p}$-valor mais processados $=0,000 ; \mathrm{p}$-valor refeições $=0,000, \mathrm{p}$-valor carne $=0,000)$. A tabela que apresenta as cidades com diferença significativa de satisfação com o sabor, considerando 5\% de significância, está descrita no Apêndice B.

\subsubsection{Satisfação com as qualidades saudáveis}

A Tabela 28 apresenta as estatísticas descritivas com relação à satisfação com as qualidades saudáveis do produto.

Tabela 28 - Satisfação com as qualidades saudáveis do produto

\begin{tabular}{|c|c|c|c|c|c|c|}
\hline \multicolumn{7}{|c|}{ Satisfação com as qualidades saudáveis do produto } \\
\hline \multicolumn{2}{|l|}{ Cidade } & $\begin{array}{c}\text { Produtos } \\
\text { Frescos }\end{array}$ & $\begin{array}{c}\text { Frescos } \\
\text { Pouco } \\
\text { Processados }\end{array}$ & $\begin{array}{c}\text { Mais } \\
\text { Processados }\end{array}$ & Refeições & $\begin{array}{c}\text { Produtos } \\
\text { Carne }\end{array}$ \\
\hline \multirow{3}{*}{$\begin{array}{c}\text { Porto } \\
\text { Alegre }\end{array}$} & Média & 5,48 & 5,38 & 5,29 & 5,59 & 5,84 \\
\hline & $\begin{array}{l}\text { Desvio } \\
\text { padrão }\end{array}$ & 1,10 & 1,04 & 0,90 & 1,07 & 0,92 \\
\hline & $\begin{array}{l}\text { Coef. } \\
\text { Variação }\end{array}$ & $20 \%$ & $19 \%$ & $17 \%$ & $19 \%$ & $16 \%$ \\
\hline \multirow{3}{*}{$\begin{array}{l}\text { Santa } \\
\text { Rosa }\end{array}$} & Média & 6,62 & 6,56 & 6,85 & 6,78 & 6,63 \\
\hline & $\begin{array}{l}\text { Desvio } \\
\text { padrão }\end{array}$ & 0,89 & 0,72 & 0,36 & 0,42 & 0,74 \\
\hline & $\begin{array}{l}\text { Coef. } \\
\text { Variação }\end{array}$ & $13 \%$ & $11 \%$ & $5 \%$ & $6 \%$ & $11 \%$ \\
\hline Curitiba & Média & 4,89 & 5,06 & 5,26 & 5,22 & 4,63 \\
\hline
\end{tabular}




\begin{tabular}{|c|c|c|c|c|c|c|}
\hline & $\begin{array}{l}\text { Desvio } \\
\text { padrão }\end{array}$ & 1,29 & 1,46 & 1,37 & 1,24 & 1,55 \\
\hline & $\begin{array}{l}\text { Coef. } \\
\text { Variação }\end{array}$ & $26 \%$ & $29 \%$ & $26 \%$ & $24 \%$ & $34 \%$ \\
\hline \multirow{3}{*}{$\begin{array}{c}\text { Ponta } \\
\text { Grossa }\end{array}$} & Média & 5,94 & 5,97 & 5,60 & 5,85 & 5,73 \\
\hline & $\begin{array}{l}\text { Desvio } \\
\text { padrão }\end{array}$ & 0,89 & 1,35 & 1,07 & 0,96 & 0,91 \\
\hline & $\begin{array}{l}\text { Coef. } \\
\text { Variação }\end{array}$ & $15 \%$ & $23 \%$ & $19 \%$ & $16 \%$ & $16 \%$ \\
\hline \multirow[t]{3}{*}{ Cuiabá } & Média & 3,49 & 3,97 & 3,94 & 4,19 & 3,59 \\
\hline & $\begin{array}{l}\text { Desvio } \\
\text { padrão }\end{array}$ & 2,48 & 2,28 & 2,15 & 2,22 & 2,37 \\
\hline & $\begin{array}{l}\text { Coef. } \\
\text { Variação }\end{array}$ & $71 \%$ & $57 \%$ & $54 \%$ & $53 \%$ & $66 \%$ \\
\hline \multirow{3}{*}{$\begin{array}{l}\text { Campo } \\
\text { Verde }\end{array}$} & Média & 3,87 & 5,45 & 4,64 & 5,22 & 4,42 \\
\hline & $\begin{array}{l}\text { Desvio } \\
\text { padrão }\end{array}$ & 2,24 & 1,75 & 1,57 & 2,07 & 2,20 \\
\hline & $\begin{array}{l}\text { Coef. } \\
\text { Variação }\end{array}$ & $58 \%$ & $32 \%$ & $34 \%$ & $40 \%$ & $50 \%$ \\
\hline \multirow[t]{3}{*}{ Goiânia } & Média & 4,99 & 4,90 & 5,38 & 5,62 & 5,07 \\
\hline & $\begin{array}{l}\text { Desvio } \\
\text { padrão }\end{array}$ & 1,95 & 1,76 & 1,45 & 1,54 & 1,76 \\
\hline & $\begin{array}{l}\text { Coef. } \\
\text { Variação }\end{array}$ & $39 \%$ & $36 \%$ & $27 \%$ & $27 \%$ & $35 \%$ \\
\hline \multirow{3}{*}{$\begin{array}{c}\text { Rio } \\
\text { Verde }\end{array}$} & Média & 4,98 & 5,31 & 5,52 & 5,07 & 5,18 \\
\hline & $\begin{array}{l}\text { Desvio } \\
\text { padrão }\end{array}$ & 2,07 & 1,98 & 1,81 & 1,96 & 1,95 \\
\hline & $\begin{array}{l}\text { Coef. } \\
\text { Variação }\end{array}$ & $42 \%$ & $37 \%$ & $33 \%$ & $39 \%$ & $38 \%$ \\
\hline
\end{tabular}

Novamente Santa Rosa apresenta os maiores níveis de satisfação em relação aos produtos.

Foi aplicado então o teste de Kruskall Wallis para verificar a existência de diferença significativa de satisfação entre as cidades estudadas, sendo indicado que há diferença significativa para pelo menos um par de cidades em todas as categorias de produtos ( $\mathrm{p}$-valor frescos $=0,000$; $\mathrm{p}$-valor pouco processados $=0,000 ; \mathrm{p}$-valor mais processados $=0,000 ; \mathrm{p}$-valor refeições $=0,000, \mathrm{p}$-valor carne $=0,000)$. A tabela contendo as cidades com diferença significativa de satisfação com as qualidades saudáveis dos produtos, considerando 5\% de significância, está no Apêndice C. 


\subsubsection{Satisfação com a facilidade de preparo}

A Tabela 29 apresenta as estatísticas descritivas sobre a satisfação com a facilidade de preparo dos produtos.

Tabela 29 - Satisfação com a facilidade de preparo

\begin{tabular}{|c|c|c|c|c|c|c|}
\hline \multicolumn{7}{|c|}{ Satisfação com a Facilidade de Preparo } \\
\hline \multicolumn{2}{|l|}{ Cidade } & $\begin{array}{c}\text { Produtos } \\
\text { Frescos }\end{array}$ & $\begin{array}{c}\text { Frescos } \\
\text { Pouco } \\
\text { Processados }\end{array}$ & $\begin{array}{c}\text { Mais } \\
\text { Processados }\end{array}$ & Refeições & $\begin{array}{c}\text { Produtos } \\
\text { Carne }\end{array}$ \\
\hline \multirow{3}{*}{$\begin{array}{c}\text { Porto } \\
\text { Alegre }\end{array}$} & Média & 5,53 & 5,50 & 5,14 & 5,49 & 6,39 \\
\hline & \begin{tabular}{|l|} 
Desvio \\
padrão
\end{tabular} & 1,32 & 1,14 & 1,56 & 1,41 &, 72 \\
\hline & \begin{tabular}{|l|} 
Coef. \\
Variação
\end{tabular} & $24 \%$ & $21 \%$ & $30 \%$ & $26 \%$ & $11 \%$ \\
\hline \multirow{3}{*}{$\begin{array}{l}\text { Santa } \\
\text { Rosa }\end{array}$} & Média & 5,56 & 6,03 & 5,36 & 5,50 & 6,85 \\
\hline & $\begin{array}{l}\text { Desvio } \\
\text { padrão }\end{array}$ & 1,02 &, 81 & ,93 & 1,00 &, 48 \\
\hline & \begin{tabular}{|l} 
Coef. \\
Variação
\end{tabular} & $18 \%$ & $13 \%$ & $17 \%$ & $18 \%$ & $7 \%$ \\
\hline \multirow[t]{3}{*}{ Curitiba } & Média & 5,10 & 5,47 & 5,33 & 5,87 & 6,15 \\
\hline & \begin{tabular}{|l|} 
Desvio \\
padrão
\end{tabular} & 1,53 & 1,61 & 1,77 & 1,38 & 1,08 \\
\hline & \begin{tabular}{|l|} 
Coef. \\
Variação
\end{tabular} & $30 \%$ & $29 \%$ & $33 \%$ & $23 \%$ & $18 \%$ \\
\hline \multirow{3}{*}{$\begin{array}{l}\text { Ponta } \\
\text { Grossa }\end{array}$} & Média & 6,11 & 6,23 & 6,00 & 6,19 & 6,24 \\
\hline & $\begin{array}{l}\text { Desvio } \\
\text { padrão }\end{array}$ & ,74 & ,76 & ,94 & ,74 & ,58 \\
\hline & \begin{tabular}{|l|} 
Coef. \\
Variação
\end{tabular} & $12 \%$ & $12 \%$ & $16 \%$ & $12 \%$ & $9 \%$ \\
\hline \multirow[t]{3}{*}{ Cuiabá } & Média & 5,24 & 5,71 & 5,32 & 6,11 & 5,90 \\
\hline & $\begin{array}{l}\text { Desvio } \\
\text { padrão }\end{array}$ & 1,57 & 1,64 & 1,93 & 1,45 & 1,37 \\
\hline & $\begin{array}{l}\text { Coef. } \\
\text { Variação }\end{array}$ & $30 \%$ & $29 \%$ & $36 \%$ & $24 \%$ & $23 \%$ \\
\hline \multirow{3}{*}{$\begin{array}{l}\text { Campo } \\
\text { Verde }\end{array}$} & Média & 5,35 & 5,73 & 5,91 & 5,85 & 5,30 \\
\hline & $\begin{array}{l}\text { Desvio } \\
\text { padrão }\end{array}$ & 1,33 & 1,19 & 1,04 & 1,62 & 1,20 \\
\hline & \begin{tabular}{|l|} 
Coef. \\
Variação
\end{tabular} & $25 \%$ & $21 \%$ & $18 \%$ & $28 \%$ & $23 \%$ \\
\hline Goiânia & Média & 5,76 & 5,68 & 5,56 & 5,79 & 6,15 \\
\hline
\end{tabular}




\begin{tabular}{c|l|r|r|r|r|r} 
& $\begin{array}{l}\text { Desvio } \\
\text { padrão }\end{array}$ & 1,39 & 1,35 & 1,55 & 1,32 & 1,20 \\
\cline { 2 - 7 } & $\begin{array}{l}\text { Coef. } \\
\text { Variação }\end{array}$ & $24 \%$ & $24 \%$ & $28 \%$ & $23 \%$ & $19 \%$ \\
\hline \multirow{2}{*}{$\begin{array}{c}\text { Rio } \\
\text { Verde }\end{array}$} & Média & 6,02 & 5,69 & 5,86 & 5,83 & 6,01 \\
\cline { 2 - 7 } & $\begin{array}{l}\text { Desvio } \\
\text { padrão }\end{array}$ & 1,42 & 1,72 & 1,74 & 1,62 & 1,42 \\
\cline { 2 - 7 } & $\begin{array}{l}\text { Coef. } \\
\text { Variação }\end{array}$ & $24 \%$ & $30 \%$ & $30 \%$ & $28 \%$ & $24 \%$ \\
\hline
\end{tabular}

Aplicou-se o teste de Kruskall Wallis para verificar a existência de diferença significativa de satisfação entre as cidades estudadas nas diferentes dimensões de produtos. O teste indicou que há diferença significativa para pelo menos um par de cidades em todas nas categorias "produtos frescos", "refeições" e "produtos de carne" (p-valor frescos $=0,001$; p-valor pouco processados $=0,000 ; \mathrm{p}$-valor mais processados $=0,000 ; \mathrm{p}$-valor refeições $=0,013$, p-valor carne $=0,000)$. A tabela que apresenta as cidades com diferença significativa de satisfação com a facilidade de preparo dos produtos, considerando 5\% de significância, está no Apêndice D.

\subsubsection{Satisfação com o preço}

A Tabela 30 a seguir apresenta as estatísticas descritivas sobre a satisfação com relação ao preço dos produtos.

Tabela 30 - Satisfação com o preço do produto

\begin{tabular}{c|l|r|r|r|r|r}
\hline \multicolumn{2}{|c|}{ Satisfação com o preço do produto } \\
\hline \multirow{2}{*}{$\begin{array}{c}\text { Cidade } \\
\text { Produtos } \\
\text { Frescos }\end{array}$} & $\begin{array}{c}\text { Frescos } \\
\text { Pouco } \\
\text { Processados }\end{array}$ & $\begin{array}{c}\text { Mais } \\
\text { Processados }\end{array}$ & Refeições & $\begin{array}{c}\text { Produtos } \\
\text { Carne }\end{array}$ \\
\hline \multirow{2}{*}{$\begin{array}{c}\text { Porto } \\
\text { Alegre }\end{array}$} & Média & 4,98 & 4,38 & 4,75 & 5,03 & 5,36 \\
\cline { 2 - 8 } & $\begin{array}{l}\text { Desvio } \\
\text { padrão }\end{array}$ & 1,46 & 1,07 & 1,65 & 1,53 & 1,24 \\
\cline { 2 - 8 } & $\begin{array}{l}\text { Coef. } \\
\text { Variação }\end{array}$ & $29 \%$ & $24 \%$ & $35 \%$ & $30 \%$ & $23 \%$ \\
\hline \multirow{2}{*}{$\begin{array}{c}\text { Santa } \\
\text { Rosa }\end{array}$} & Média & 4,67 & 4,74 & 4,58 & 4,47 & 5,42 \\
\cline { 2 - 8 } & $\begin{array}{l}\text { Desvio } \\
\text { padrão }\end{array}$ & 0,85 & 0,72 & 0,66 & 1,18 & 1,05 \\
\hline
\end{tabular}




\begin{tabular}{|c|c|c|c|c|c|c|}
\hline & $\begin{array}{l}\text { Coef. } \\
\text { Variação }\end{array}$ & $18 \%$ & $15 \%$ & $14 \%$ & $26 \%$ & $19 \%$ \\
\hline \multirow[t]{3}{*}{ Curitiba } & Média & 3,79 & 3,94 & 3,21 & 3,42 & 3,96 \\
\hline & $\begin{array}{l}\text { Desvio } \\
\text { padrão }\end{array}$ & 1,68 & 1,88 & 1,76 & 1,97 & 1,77 \\
\hline & \begin{tabular}{|l|} 
Coef. \\
Variação \\
\end{tabular} & $44 \%$ & $48 \%$ & $55 \%$ & $58 \%$ & $45 \%$ \\
\hline \multirow{3}{*}{$\begin{array}{l}\text { Ponta } \\
\text { Grossa }\end{array}$} & Média & 5,10 & 5,65 & 4,60 & 5,62 & 5,15 \\
\hline & $\begin{array}{l}\text { Desvio } \\
\text { padrão }\end{array}$ & 1,50 & 1,23 & 1,07 & 1,15 & 1,50 \\
\hline & $\begin{array}{l}\text { Coef. } \\
\text { Variação }\end{array}$ & $29 \%$ & $22 \%$ & $23 \%$ & $21 \%$ & $29 \%$ \\
\hline \multirow[t]{3}{*}{ Cuiabá } & Média & 2,96 & 3,47 & 2,88 & 3,43 & 2,87 \\
\hline & $\begin{array}{l}\text { Desvio } \\
\text { padrão }\end{array}$ & 2,31 & 2,50 & 2,36 & 2,34 & 2,35 \\
\hline & $\begin{array}{l}\text { Coef. } \\
\text { Variação }\end{array}$ & $78 \%$ & $72 \%$ & $82 \%$ & $68 \%$ & $82 \%$ \\
\hline \multirow{3}{*}{$\begin{array}{l}\text { Campo } \\
\text { Verde }\end{array}$} & Média & 3,73 & 5,45 & 5,27 & 4,80 & 4,15 \\
\hline & $\begin{array}{l}\text { Desvio } \\
\text { padrão }\end{array}$ & 2,44 & 1,81 & 2,41 & 2,52 & 2,41 \\
\hline & \begin{tabular}{|l|} 
Coef. \\
Variação
\end{tabular} & $65 \%$ & $33 \%$ & $46 \%$ & $53 \%$ & $58 \%$ \\
\hline \multirow[t]{3}{*}{ Goiânia } & Média & 4,05 & 3,97 & 4,38 & 4,69 & 4,68 \\
\hline & $\begin{array}{l}\text { Desvio } \\
\text { padrão }\end{array}$ & 1,55 & 1,43 & 1,67 & 1,26 & 1,47 \\
\hline & $\begin{array}{c}\text { Coef. } \\
\text { Variação }\end{array}$ & $38 \%$ & $36 \%$ & $38 \%$ & $27 \%$ & $31 \%$ \\
\hline \multirow{3}{*}{$\begin{array}{l}\text { Rio } \\
\text { Verde }\end{array}$} & Média & 3,25 & 3,62 & 3,81 & 3,87 & 3,94 \\
\hline & $\begin{array}{l}\text { Desvio } \\
\text { padrão }\end{array}$ & 1,96 & 2,00 & 1,83 & 1,74 & 2,03 \\
\hline & $\begin{array}{l}\text { Coef. } \\
\text { Variação }\end{array}$ & $60 \%$ & $55 \%$ & $48 \%$ & $45 \%$ & $52 \%$ \\
\hline
\end{tabular}

Mais uma vez foi aplicado o teste de Kruskall Wallis para verificar a existência de diferença significativa de satisfação entre as cidades estudadas nas diferentes dimensões de produtos. $\mathrm{O}$ teste indicou que há diferença significativa para pelo menos um par de cidades em todas as categorias de produtos ( $\mathrm{p}$-valor frescos $=0,000 ; \mathrm{p}$-valor pouco processados $=0,000 ; \mathrm{p}$-valor mais processados $=0,000 ; p$-valor refeições $=0,000, p$-valor carne $=0,000$ ). A tabela que apresenta as cidades com diferença significativa de satisfação com o preço, considerando $5 \%$ de significância, está no Apêndice E.

Realizaram-se regressões lineares stepwise (modelo de regressão em que a escolha de variáveis preditivas é realizada por um procedimento automático) com caráter exploratório, com o objetivo 
de verificar a relação das variáveis "sabor", "qualidades saudáveis do produto", "facilidade de preparo" e "preço", sobre a satisfação e geral do consumidor em relação a cada categoria de produto: frescos, pouco processados, mais processados, refeições e produtos de carne. Ressaltase que não se comprovaram os requisitos da regressão, como a homocedasticidade de variância e normalidade dos resíduos; apenas se analisaram os valores de beta padronizado (valor absoluto, que mostra qual variável é mais importante) para verificar quais seriam as variáveis de maior impacto sobre a satisfação. Os modelos não possuem caráter de previsão.

Tabela 31 - Variáveis de influência e Beta padronizado para as categorias de produto

\begin{tabular}{|c|c|c|}
\hline Produtos & Variáveis de influência & Valor Beta Padronizado \\
\hline \multirow[t]{2}{*}{ Frescos } & Sabor & 0,391 \\
\hline & Qualidades Saudáveis & 0,359 \\
\hline \multirow[t]{2}{*}{ Pouco Processados } & Sabor & 0,371 \\
\hline & Qualidades Saudáveis & 0,155 \\
\hline \multirow[t]{2}{*}{ Mais Processados } & Sabor & 0,286 \\
\hline & Qualidades Saudáveis & 0,271 \\
\hline \multirow[t]{3}{*}{ Refeições } & Qualidades Saudáveis & 0,256 \\
\hline & Sabor & 0,226 \\
\hline & Preço & 0,128 \\
\hline \multirow[t]{2}{*}{ Produtos de Carne Suína } & Sabor & 0,480 \\
\hline & Facilidade de Preparo & 0,210 \\
\hline
\end{tabular}

Pelas regressões, observa-se que, para produtos frescos, pouco processados e mais processados, as variáveis que influenciam a satisfação do consumidor são apenas o sabor e as qualidades saudáveis. Para as refeições, há influência das qualidades saudáveis, sabor e preço. Por fim, os produtos de carne são influenciados pelo sabor e pela facilidade de preparo. 


\subsubsection{Com quais produtos o respondente combina o consumo de carne suína}

Apresentam-se a seguir as estatísticas gerais de preferências por acompanhamentos aos produtos suínos. Como acompanhamento mais frequente para a costela de porco, $90 \%$ dos entrevistados citam o arroz; como segundo acompanhamento, $35,9 \%$ das pessoas citam feijão e 30,2\%, batata.

Tabela 32 - Estatísticas gerais de preferências por acompanhamentos aos produtos suínos

\begin{tabular}{|c|c|c|c|c|c|c|c|c|c|c|}
\hline \multirow[t]{2}{*}{ Produto } & \multicolumn{2}{|c|}{ Mais frequente } & \multicolumn{2}{|c|}{$\begin{array}{l}\text { Segundo mais } \\
\text { frequente }\end{array}$} & \multicolumn{2}{|c|}{$\begin{array}{l}\text { Terceiro mais } \\
\text { frequente }\end{array}$} & \multicolumn{2}{|c|}{$\begin{array}{l}\text { Quarto mais } \\
\text { frequente }\end{array}$} & \multicolumn{2}{|l|}{$\begin{array}{l}\text { Quinto } \\
\text { frequente }\end{array}$} \\
\hline & Acomp. & $\%$ & Acomp. & $\%$ & Acomp. & $\%$ & Acomp. & $\%$ & Acomp. & $\%$ \\
\hline $\begin{array}{ll}\text { Costela } & \text { de } \\
\text { porco } & \end{array}$ & Arroz & 90 & $\begin{array}{l}\text { Feijão } \\
\text { Batata }\end{array}$ & $\begin{array}{l}35,9 \\
30,2\end{array}$ & $\begin{array}{l}\text { Massa } \\
\text { Feijão }\end{array}$ & $\begin{array}{l}33,1 \\
24,6\end{array}$ & $\begin{array}{l}\text { Beb. gel. } \\
\text { Mandioca }\end{array}$ & $\begin{array}{l}25,5 \\
20,8\end{array}$ & Beb. gel. & 42,3 \\
\hline $\begin{array}{l}\text { Paleta, } \\
\text { lombo, } \\
\text { bisteca }\end{array}$ & Arroz & 92,1 & $\begin{array}{l}\text { Feijão } \\
\text { Batata }\end{array}$ & $\begin{array}{l}43,7 \\
26,9\end{array}$ & $\begin{array}{l}\text { Massa } \\
\text { Feijão }\end{array}$ & $\begin{array}{l}33,5 \\
21,9\end{array}$ & $\begin{array}{l}\text { Beb. gel. } \\
\text { Massa }\end{array}$ & $\begin{array}{l}35,9 \\
17\end{array}$ & Beb.g el. & 39,5 \\
\hline Pernil & Arroz & 84,4 & $\begin{array}{l}\text { Feijão } \\
\text { Batata }\end{array}$ & $\begin{array}{l}42,3 \\
30,5\end{array}$ & $\begin{array}{l}\text { Massa } \\
\text { Feijão }\end{array}$ & $\begin{array}{l}29,8 \\
25,4\end{array}$ & $\begin{array}{l}\text { Beb. gel. } \\
\text { Mandioca }\end{array}$ & $\begin{array}{l}40,7 \\
15,9\end{array}$ & Beb. gel. & 43,8 \\
\hline Outros & Arroz & 70 & $\begin{array}{l}\text { Feijão } \\
\text { Massa }\end{array}$ & $\begin{array}{l}36 \\
29,3\end{array}$ & $\begin{array}{l}\text { Massa } \\
\text { Mandioca }\end{array}$ & $\begin{array}{l}43,4 \\
16,4\end{array}$ & $\begin{array}{l}\text { Beb. gel. } \\
\text { Mandioca }\end{array}$ & $\begin{array}{l}31 \\
24,1\end{array}$ & $\begin{array}{l}\text { Beb. gel. } \\
\text { Vegetais }\end{array}$ & $\begin{array}{l}32 \\
22\end{array}$ \\
\hline $\begin{array}{l}\text { Pouco } \\
\text { processados }\end{array}$ & Arroz & 92,1 & $\begin{array}{l}\text { Feijão } \\
\text { Batata }\end{array}$ & $\begin{array}{l}33,6 \\
33,2\end{array}$ & $\begin{array}{l}\text { Massa } \\
\text { Feijão }\end{array}$ & $\begin{array}{l}28 \\
27\end{array}$ & $\begin{array}{l}\text { Beb. gel. } \\
\text { Massa }\end{array}$ & $\begin{array}{l}36 \\
20\end{array}$ & Beb. gel. & 36 \\
\hline $\begin{array}{l}\text { Mais } \\
\text { processados }\end{array}$ & Arroz & 91,1 & $\begin{array}{l}\text { Feijão } \\
\text { Batata }\end{array}$ & $\begin{array}{l}33,1 \\
32,6\end{array}$ & $\begin{array}{l}\text { Feijão } \\
\text { Massa }\end{array}$ & $\begin{array}{l}30,1 \\
23,9\end{array}$ & $\begin{array}{l}\text { Beb. gel. } \\
\text { Salada }\end{array}$ & $\begin{array}{l}35,4 \\
17,3\end{array}$ & Beb. gel. & 33,3 \\
\hline Refeições & Arroz & 68 & $\begin{array}{l}\text { Feijão } \\
\text { Beb.gel. }\end{array}$ & $\begin{array}{l}33,7 \\
16,5\end{array}$ & $\begin{array}{l}\text { Beb.gel. } \\
\text { Massa }\end{array}$ & $\begin{array}{l}34 \\
24,5\end{array}$ & $\begin{array}{l}\text { Beb. gel. } \\
\text { Mandioca }\end{array}$ & $\begin{array}{l}25,7 \\
25,7\end{array}$ & $\begin{array}{l}\text { Beb. gel. } \\
\text { Vegetais }\end{array}$ & $\begin{array}{l}31,8 \\
28,2\end{array}$ \\
\hline Frios & $\begin{array}{l}\text { Salada } \\
\text { Beb. gel. }\end{array}$ & $\begin{array}{l}24,9 \\
19,7\end{array}$ & $\begin{array}{l}\text { Beb. gel. } \\
\text { Condimento }\end{array}$ & $\begin{array}{l}19,4 \\
10,4\end{array}$ & $\begin{array}{l}\text { Beb. gel. } \\
\text { Massa }\end{array}$ & $\begin{array}{l}27,7 \\
14,9\end{array}$ & $\begin{array}{l}\text { Beb. gel. } \\
\text { Mandioca }\end{array}$ & $\begin{array}{l}19 \\
19\end{array}$ & $\begin{array}{l}\text { Beb. gel. } \\
\text { Mandioca }\end{array}$ & $\begin{array}{l}25 \\
22,2\end{array}$ \\
\hline
\end{tabular}




\begin{tabular}{l|l|l|l|l|l|l|l|l|l|l}
\hline & Arroz & 13,7 & & & & & & & & \\
& Condimento & 13,7 & & & & & & & \\
\hline Bacon & Arroz & 57,2 & Massa & 26,1 & Massa & 31,1 & Beb. gel. & 44,6 & Beb. gel. & 35,8 \\
& Massa & 26,9 & Feijão & 23,5 & Condimento & 16,2 & & & & \\
\hline Salsichas & Arroz & 73,2 & Feijão & 29,3 & Massa & 38,3 & Beb. gel. & 40,4 & Beb. gel. & 36,7 \\
\hline Patê & Condimento & 31,3 & Beb.gel. & 23,8 & Beb.gel. & 20,7 & & & & \\
\hline
\end{tabular}

Nota: * O quarto e quinto acompanhamentos mais frequentes do patê não são mencionados, pois houve menos de 10 respostas nessas questões.

Observa-se que o arroz é o acompanhamento mais citado pelos entrevistados para os produtos suínos, com exceção dos frios e patês. Os outros acompanhamentos mais citados são o feijão, massas e bebidas frias. Tradicionalmente, o brasileiro consome arroz diariamente em suas refeições. Aliás, a refeição mais usual é arroz e feijão com algum acompanhamento, que neste caso é a carne suína. A massa também costuma ser acompanhada de alguma proteína, especialmente a carne. E pelo fato de ser um país com altas temperaturas na maior parte do ano, o acompanhamento de bebidas geladas é uma consequência natural.

Apresentados os resultados analisados por esta tese, parte-se agora para a descrição de algumas implicações teóricas e gerenciais que esses resultados geraram, com o fim de aprofundar o conhecimento do consumidor de carne suína e produtos derivados no Brasil. Percebe-se que algumas suposições práticas que se faziam a respeito do consumidor puderam ser confirmadas pelas análises estatísticas, enquanto queoutras novas foram encontradas. Isso gera uma série de informações que, se utilizadas de maneira eficiente, podem possibilitar um melhor direcionamento das ações de vários agentes da cadeia de carne suína no Brasil. 


\section{IMPLICAÇÕES TEÓRICO-CIENTÍFICAS E GERENCIAIS}

\subsection{Implicações Teórico-científicas}

Pelos resultados obtidos, percebe-se que várias das escalas utilizadas não puderam ser validadas na amostra brasileira, ou não tiveram todas as suas dimensões confirmadas, como o $F R L$ ou o $P V Q$. Isto implica a necessidade de buscar outras escalas, ou mesmo de criá-las, a fim de possibilitar um melhor entendimento sobre o consumidor brasileiro de carne suína.

Vale também replicar esta pesquisa a outros produtos a fim de testar as escalas e verificar se não foram validadas com o produto carne suína especificamente, ou se se trata de um problema de adaptação das próprias escalas.

Além disso, mesmo para as dimensões validadas, em geral os resultados estatísticos mostraram valores considerados baixos, o que demonstra que, pela metodologia e pelas escalas utilizadas, tratava-se de preditores fracos do consumo do produto. Assim, seria interessante realizar novos estudos que incluíssem na pesquisa outros fatores, como os hábitos culturais e de consumo ou o efeito da renda e das mudanças de renda dos consumidores de carne suína no Brasil.

Estudos posteriores deveriam ser feitos também envolvendo uma amostra maior, explorando inclusive localidades diferentes no país, como as grandes cidades e grandes centros consumidores como Rio de Janeiro e São Paulo, onde muito provavelmente se encontrará outro tipo de consumidor. Também as características desse consumidor deveriam ser estudadas a fim de identificar as características sociodemográficas associadas ao consumo de carne suína.

\section{Para a formatação de políticas públicas}

A carne suína é ainda muito pouco consumida no Brasil, apesar de ser um item bastante importante na alimentação humana por seu alto valor nutricional, principalmente por apresentar uma alta e crescente produção de boa qualidade no país e de ser bem aceita pela população (NEVES et al, 2008). Iniciativas como a introdução da carne suína e derivados na merenda escolar, recentemente aprovada no estado do Rio Grande do Sul (PORTAL DO AGRONEGÓCIO, 2010) e que vem sendo discutida em várias outras regiões, ou reduzir as altas 
taxas de juros por toda a cadeia produtiva a fim de incentivar o suinocultor e possibilitar a diminuição de preços ao consumidor podem ser rápida e facilmente implementadas a fim de aumentar a demanda pelo produto, além de melhorar a situação nutricional da população brasileira.

Sabe-se, também, que existem em certas regiões do país grandes áreas onde as tradicionais produções agrícolas foram substituídas pela produção de cana-de-açúcar. No entanto, brevemente será obrigatório que a colheita da cana seja totalmente mecanizada, mas há certas áreas produtivas aonde as máquinas não conseguem chegar. A suinocultura pode surgir aí como uma opção de ocupação dessas áreas, uma vez que o espaço necessário para a instalação de uma granja, dependendo do seu porte, não é tão grande.

\subsection{Implicações Gerenciais da Pesquisa: Mensagens ao SAG da Carne Suína}

De maneira geral, a imagem do suíno como um animal gorduroso, criado em condições precárias e alimentado inadequadamente está começando a mudar. Produtores pequenos e não especializados que tinham a atividade como secundária estão sendo confrontados com o surgimento e fortalecimento da produção suína industrial e profissional, que começaram a demandar uma oferta constante, com padrões de produção muito bem definidos (MIELE, 2007). Comparando os sistemas de produção entre Brasil e Dinamarca (considerado um dos países mais avançados em termos de produção de suínos no mundo), o que foi possível nas reuniões e visitas realizadas pela autora desta tese aos dois países, percebe-se que em ambos os sistemas de produção são praticamente idênticos (da criação das matrizes até a engorda dos leitões); as instalações, bastante parecidas, tendo, no entanto, as variações inerentes às enormes diferenças de clima entre os países, já que no Brasil é possível a criação a céu aberto durante grande parte do ano, acontecendo o inverso na Dinamarca.

Algumas das grandes diferenças encontradas entre ambos os sistemas de produção referem-se basicamente às tecnologias utilizadas para a distribuição de ração aos animais. Outra diferença refere-se à utilização da inseminação artificial, que é mais frequente no Brasil, nas granjas de suínos. Isso ocorre principalmente por problemas de bem-estar animal, que já é uma séria 
preocupação nos países europeus, mas ainda tem pouco efeito no Brasil. Na Dinamarca privilegiam-se os aspectos mais naturais da produção, como a monta natural.

Outro fator diferencial entre os dois países está no uso de mão de obra, que é mais intenso no Brasil, enquanto na Dinamarca ela é substituída por equipamentos modernos e automatizados. Ainda assim, os suinocultores brasileiros estão sendo desafiados a utilizar mais novas tecnologias e mudar para se adaptar, a fim de satisfazer a indústria e, consequentemente, as necessidades dos consumidores.

Alguns dos principais problemas do baixo consumo de carne suína no Brasil incluem a baixa adaptação aos atributos que os consumidores desejam, como maior variedade de cortes, o que demonstra a necessidade de treinar os varejistas para que ofereçam esses cortes, e não apenas os três tipos de cortes grandes e de preparo lento comumente encontrados no varejo, que são o lombo, o pernil e a costela, todos vendidos inteiros e não em pedaços, em bifes ou moídos, o que já facilitaria o preparo, agregando valor ao produto, na visão do consumidor.

O consumidor também quer cortes menores, porcionados, para que possam fazer parte de seu cardápio diário e não apenas em ocasiões especiais, conforme foi revelado pela pesquisa no item frequência de consumo, que indicou que o consumidor consome carne suína 'em qualquer dia'. Ele também revelou consumir 'em casa' e 'com a família', possivelmente pela falta de opções de pratos de carne suína em restaurante e principalmente em lanchonetes e redes de fast food. Estas, por sua crescente importância e aceitação, poderiam funcionar como geradores de hábitos de consumo, ao oferecer mais e diferentes produtos aos consumidores.

Estes também querem maior conveniência. No entanto, há muito poucos produtos prontos para cozinhar no mercado brasileiro (BARCELLOS et al, 2008). Aqui surge mais uma oportunidade para as empresas que desejarem introduzir novos produtos em seu portfólio, para atender a esse consumidor cada vez mais exigente e objetivo.

Encontrou-se na pesquisa um baixo consumo de produtos processados (pratos), o que, acreditase, deve-se à falta de variedade desses produtos nos pontos de venda. Isso indica uma grande oportunidade para as empresas brasileiras que desejem investir na criação desse tipo de produto para o consumidor brasileiro.

Além disso, há outras preocupações dos consumidores, como saúde e forma física, o que faz com que os consumidores procurem cada vez mais produtos com menores quantidades de gordura (existente na carne do suíno tradicional) e sódio (existente em grandes teores nos produtos 
processados, especialmente os embutidos), porém com altos níveis de qualidade e segurança alimentar (DALLARI, 2007; MILAN, 2008).

No entanto, pouco se tem divulgado a respeito de algumas das qualidades nutricionais da carne suína, que, além do alto valor nutricional oferecido e da quantidade de ferro, importante para a saúde humana, também apresenta os menores teores de sódio entre os tipos mais consumidos de proteína animal (ROPPAb, 2006), o que é bastante importante para problemas de saúde pública, como a hipertensão.

Pelos níveis de penetração dos produtos e pela satisfação encontrada, principalmente com relação aos aspectos gerais dos produtos e a seu sabor, percebe-se que, tendo os produtos disponíveis para venda e com níveis razoáveis de preços em comparação com os produtos concorrentes (de outras carnes, por exemplo), não será tarefa árdua aumentar o consumo de carne suína e derivados no Brasil.

Os brasileiros estão em geral satisfeitos com os produtos listados no questionário. Em termos de posicionamento de produto e do desenvolvimento de novos produtos, a indústria deveria levar em consideração questões acerca dos aspectos percebidos da produção, hábitos culturais de consumo e disponibilidade geral dos produtos, em termos de pouca variedade de cortes, cortes grandes e pouco atrativos e nenhuma conveniência.

Além disso, deveria investir em pesquisas que possibilitassem a diminuição dos teores de gordura e sódio nos produtos industrializados, diminuindo assim a rejeição ao produto pelas pessoas cuja preocupação básica é a saúde.

Ainda, faltam ações coletivas no sentido de promover ações para aumentar o consumo do produto em geral. Na verdade, a maior ação nesse sentido de que se tem notícia vem sendo promovida por uma associação de produtores e não da indústria: o Programa Nacional de Desenvolvimento da Suinocultura (PNDS), de iniciativa da Associação Brasileira de Criadores de Suínos (ABCS).

É absolutamente necessário que se divulguem ao consumidor os avanços por que vem passando a suinocultura brasileira em termos de manejo e alojamento dos animais, limpeza das instalações, cuidados com a higiene e a saúde dos animais nas granjas onde se pratica a chamada suinocultura industrial. Somente assim se conseguirá diminuir o preconceito que ainda existe em relação ao animal que era porco, mas “fez regime e virou suíno” (ROPPAb, 2006). 
A tendência esperada, de que quanto menos processado é o produto mais ele tende a ser preparado ou finalizado em casa, é também confirmada pelo consumidor brasileiro. E quanto mais processados, mais os produtos tendem a ser somente finalizados em casa ou comprados prontos para ser consumidos.

Informações corretas deveriam ser divulgadas sobre as enormes mudanças que ocorreram nos últimos anos em todas as fases da produção de suínos no Brasil, da criação à industrialização dos produtos, e também sobre os benefícios do consumo de carne suína e os eventuais riscos associados aos diferentes tipos de carne e produtos derivados. Deveriam ser adotadas estratégias de colocação de preços e para melhorar a conveniência da carne fresca e dos produtos processados, a fim de melhorar a satisfação dos respondentes em relação aos produtos de carne suína.

\section{Exemplo a ser seguido}

O Q-PorkChains é um bom conceito a ser seguido. Em geral, os pesquisadores focam apenas um aspecto dos produtos e o estudam em detalhe, esquecendo-se das interações com outros importantes aspectos dentro do campo científico. O Q-PorkChains lida com uma larga variedade de diferentes aspectos dentro da produção de suínos e de carne suína, com especialistas interagindo a partir de áreas distintas como a genética animal, a produção industrial e estudos sobre o consumidor final.

É claro que não se podem resolver todos os problemas, mas qualquer que seja o avanço obtido por alguma das áreas dentro do projeto, em pequena ou larga escala, ele é comunicado a toda a cadeia, já que do projeto participam universidades e institutos de pesquisa, ao lado de empresas. Assim, a troca é constante e altamente enriquecedora para ambos os lados: a indústria transforma o conhecimento em produtos e know-how, baseada no conhecimento sintetizado oferecido pelos pesquisadores. Estes explicam a razão por que aquilo funciona, e a ciência beneficia-se. Por sua vez, a indústria ajuda a apontar os importantes temas do mercado para serem estudados academicamente.

Seria altamente benéfico para o Brasil, que tem um baixo consumo de carne suína, a formatação de um projeto nesses moldes, unindo empresas, associações e universidades com o objetivo comum de melhorar a qualidade da carne, divulgar essas melhorias e assim aumentar o consumo geral do produto. 


\subsection{Síntese dos Resultados}

O Quadro 9 apresenta uma síntese dos resultados encontrados e algumas possíveis implicações acadêmicas e de marketing.

Quadro 9 - Síntese dos resultados encontrados e suas implicações

\begin{tabular}{|c|c|c|c|}
\hline Resultado & Significado & $\begin{array}{c}\text { Implicações Acadêmicas } \\
\text { e Científicas }\end{array}$ & Implicações para o Marketing \\
\hline $\begin{array}{l}\text { Entre as } 23 \text { dimensões da } \\
\text { escala } F R L \text {, apenas quatro } \\
\text { apresentaram confiabilidade } \\
\text { satisfatória na amostra } \\
\text { brasileira. }\end{array}$ & $\begin{array}{l}\text { O estilo de vida dos } \\
\text { consumidores tem } \\
\text { pouca influência no } \\
\text { consumo de carne } \\
\text { suína. }\end{array}$ & $\begin{array}{l}\text { Criação/busca de outras } \\
\text { escalas de estilo de vida } \\
\text { relacionado a alimentos } \\
\text { para novos testes e } \\
\text { análises. }\end{array}$ & $\begin{array}{l}\text { Utilização de outras bases para } \\
\text { as ações de marketing. }\end{array}$ \\
\hline $\begin{array}{l}\text { Entre os } 10 \text { valores da } \\
\text { escala de Schwartz, apenas } \\
\text { nove puderam ser validados } \\
\text { na amostra brasileira, e } \\
\text { ainda assim de maneira } \\
\text { agregada } \\
\text { consistente. }\end{array}$ & $\begin{array}{l}\text { Os valores dos } \\
\text { consumidores têm } \\
\text { pouca influência no } \\
\text { consumo de produtos } \\
\text { de carne suína. }\end{array}$ & $\begin{array}{l}\text { Criação/busca de outras } \\
\text { escalas de valores para } \\
\text { novos testes e análises. }\end{array}$ & $\begin{array}{l}\text { Deixar de enfatizar valores dos } \\
\text { consumidores como indutores de } \\
\text { consumo nas ações de marketing } \\
\text { das empresas. }\end{array}$ \\
\hline $\begin{array}{l}\text { Entre as } 23 \text { dimensões da } \\
\text { escala de atitudes, apenas } \\
\text { três confirmaram-se na } \\
\text { amostra brasileira. }\end{array}$ & $\begin{array}{lr}\text { Atitudes } & \text { são } \\
\text { preditores } & \text { fracos do } \\
\text { consumo de carne } \\
\text { suína e produtos } \\
\text { derivados. }\end{array}$ & $\begin{array}{l}\text { Criação/busca de outras } \\
\text { escalas de valores para } \\
\text { futuros testes e análises. }\end{array}$ & $\begin{array}{l}\text { Não enfatizar atitudes dos } \\
\text { consumidores como indutores de } \\
\text { consumo nas ações de marketing } \\
\text { das empresas. }\end{array}$ \\
\hline $\begin{array}{l}\text { É bastante significativo o } \\
\text { número de pessoas que } \\
\text { nunca consome alguns itens } \\
\text { de carne suína. }\end{array}$ & $\begin{array}{l}\text { Existe espaço para } \\
\text { aumentar o consumo } \\
\text { de carne suína no } \\
\text { Brasil. }\end{array}$ & $\begin{array}{l}\text { Confirmam-se estudos que } \\
\text { afirmam que um dos } \\
\text { fatores do baixo consumo } \\
\text { de carne suína no Brasil é } \\
\text { a pouca disponibilidade } \\
\text { dos produtos no varejo. }\end{array}$ & $\begin{array}{l}\text { É importante que se façam } \\
\text { campanhas institucionais para } \\
\text { aumentar o consumo de carne } \\
\text { suína no Brasil }\end{array}$ \\
\hline $\begin{array}{l}\text { Embutidos são o único item } \\
\text { que aparece com } \\
\text { significativa frequência de } \\
\text { consumo diário. }\end{array}$ & $\begin{array}{lr}\text { Produtos } & \text { como } \\
\text { presunto e mortadela } \\
\text { fazem parte } & \text { do } \\
\text { cardápio diário dos } \\
\text { consumidores } \\
\text { amostra. }\end{array}$ & $\begin{array}{l}\text { Confirmam-se afirmações } \\
\text { de que grande parte do } \\
\text { consumo de carne suína no } \\
\text { Brasil é de embutidos. }\end{array}$ & $\begin{array}{l}\text { Reafirma-se o fator conveniência } \\
\text { como grande tendência de } \\
\text { consumo de alimentos. }\end{array}$ \\
\hline A carne suína é comprada & consumidores & culturais & Necessidade de informar \\
\hline
\end{tabular}




\begin{tabular}{|c|c|c|c|}
\hline em sua maioria fresca. & $\begin{array}{l}\text { preferem comprar } \\
\text { carne fresca, talvez } \\
\text { ligando essa } \\
\text { característica a saúde. }\end{array}$ & $\begin{array}{l}\text { tradicionais ainda } \\
\text { prevalecem na mente do } \\
\text { consumidor brasileiro em } \\
\text { favor de produtos frescos e } \\
\text { não congelados. }\end{array}$ & $\begin{array}{l}\text { consumidor sobre as vantagens } \\
\text { do produto congelado em termos } \\
\text { de conveniência e durabilidade. }\end{array}$ \\
\hline $\begin{array}{l}\text { A maior parte dos } \\
\text { consumidores compra carne } \\
\text { suína e produtos derivados } \\
\text { nos supermercados. }\end{array}$ & $\begin{array}{l}\text { Os supermercados } \\
\text { são o local de compra } \\
\text { preferido no varejo de } \\
\text { alimentos. }\end{array}$ & $\begin{array}{l}\text { Confirma-se a tendência } \\
\text { mundial em favor de one } \\
\text { stop shop, favorecendo a } \\
\text { compra em um só local. }\end{array}$ & $\begin{array}{l}\text { Fortalecer a presença dos } \\
\text { produtos nos supermercados. }\end{array}$ \\
\hline $\begin{array}{l}\text { A maior parte dos produtos } \\
\text { de carne suína é consumida } \\
\text { 'em qualquer dia'. }\end{array}$ & $\begin{array}{l}\text { O consumo de } \\
\text { produtos de carne } \\
\text { suína não está tão } \\
\text { ligado a ocasiões } \\
\text { especiais. }\end{array}$ & $\begin{array}{l}\text { Este resultado é muito } \\
\text { favorável, já que se } \\
\text { conjectura que o aumento } \\
\text { de consumo só ocorrerá } \\
\text { quando fizer parte do } \\
\text { hábito diário dos } \\
\text { consumidores. }\end{array}$ & $\begin{array}{l}\text { Diversificar ainda mais os cortes } \\
\text { à disposição dos consumidores } \\
\text { nos locais de venda no varejo. }\end{array}$ \\
\hline $\begin{array}{l}\text { O pernil é consumido } \\
\text { principalmente 'em ocasiões } \\
\text { especiais'. }\end{array}$ & $\begin{array}{l}\text { Trata-se de um corte } \\
\text { que, por seu tamanho } \\
\text { e maneira de preparo } \\
\text { favorece essa ocasião } \\
\text { de consumo. }\end{array}$ & $\begin{array}{llr}\text { Realizar } & \text { estudos } & \text { que } \\
\text { busquem } & \text { maneiras } & \text { de } \\
\text { diversificar a apresentação } & \\
\text { do produto. } & \end{array}$ & $\begin{array}{l}\text { Facilitar o consumo mais } \\
\text { diversificado, por exemplo } \\
\text { vendendo-o sem osso. }\end{array}$ \\
\hline $\begin{array}{l}\text { Em relação à companhia e } \\
\text { local de consumo, os } \\
\text { produtos são consumidos } \\
\text { principalmente 'com a } \\
\text { família' e 'em casa'. }\end{array}$ & $\begin{array}{l}\text { Isto parece } \\
\text { demonstrar mais uma } \\
\text { vez que o consumo de } \\
\text { carne suína ainda é } \\
\text { feito principalmente } \\
\text { em casa, que é onde } \\
\text { as famílias se reúnem. }\end{array}$ & $\begin{array}{lcr}\text { Realizar } & \text { estudos } & \text { sobre } \\
\text { novos } & \text { produtos } & \text { que } \\
\text { possam } & \text { ser consumidos } \\
\text { fora de casa }\end{array}$ & $\begin{array}{l}\text { Criar produtos novos para serem } \\
\text { consumidos em bares e } \\
\text { restaurantes, e em happy hour } \\
\text { com amigos. Aumentar a } \\
\text { presença de produtos de carne } \\
\text { suína em restaurantes e } \\
\text { lanchonetes. }\end{array}$ \\
\hline $\begin{array}{l}\text { Com relação à produção, os } \\
\text { consumidores preferem } \\
\text { produções com máximo } \\
\text { esforço para reduzir o } \\
\text { impacto ambiental, baixa } \\
\text { densidade de produção, piso } \\
\text { ripado, alojamento com } \\
\text { acesso ao ar livre, animais } \\
\text { alimentados de forma a } \\
\text { produzirem carne com } \\
\text { gordura saudável e } \\
\text { qualidade constante. }\end{array}$ & $\begin{array}{l}\text { Os consumidores } \\
\text { estão cada vez mais } \\
\text { preocupados com o } \\
\text { impacto ambiental da } \\
\text { produção, bem-estar } \\
\text { dos animais e saúde. }\end{array}$ & $\begin{array}{l}\text { Passar essas informações } \\
\text { aos produtores para que se } \\
\text { adaptem a esse tipo de } \\
\text { produção. } \\
\text { produtores } \\
\text { funcionários }\end{array}$ & $\begin{array}{l}\text { Incluir no marketing dos } \\
\text { produtos informações sobre o } \\
\text { tipo de produção utilizado. }\end{array}$ \\
\hline $\begin{array}{l}\text { Consumidores no } \text { sul são } \\
\text { mais favoráveis à } \\
\text { intensiação } \\
\text { externo e baixo impacto }\end{array}$ & $\begin{array}{l}\text { Existem diferenças de } \\
\text { preferência para os } \\
\text { consumidores em } \\
\text { relação aos sistemas }\end{array}$ & $\begin{array}{l}\text { Realizar mais estudos que } \\
\text { expliquem melhor essas } \\
\text { diferenças. }\end{array}$ & $\begin{array}{l}\text { Verificar quais são essas } \\
\text { diferenças e adaptar o marketing } \\
\text { regional a elas, enfatizando nas } \\
\text { informações ao consumidor os }\end{array}$ \\
\hline
\end{tabular}




\begin{tabular}{|c|c|c|c|}
\hline ambiental. & produtivos. & & aspectos favoráveis da produção. \\
\hline $\begin{array}{l}\text { Os fatores mais importantes } \\
\text { para a amostra estudada são } \\
\text { o impacto do sistema de } \\
\text { produção de suínos sobre o } \\
\text { meio ambiente (solo, ar e } \\
\text { água); a densidade da } \\
\text { produção é o menos } \\
\text { importante } \\
\text { considerada a preferência } \\
\text { geral. }\end{array}$ & $\begin{array}{l}\text { O fator meio } \\
\text { ambiente vem se } \\
\text { tornando cada vez } \\
\text { mais importante para } \\
\text { o consumidor final de } \\
\text { carne suína. }\end{array}$ & $\begin{array}{l}\text { Realizar estudos que } \\
\text { minimizem os impactos da } \\
\text { produção sobre o meio } \\
\text { ambiente e capacitar os } \\
\text { produtores no sentido de } \\
\text { implantá-los. }\end{array}$ & $\begin{array}{l}\text { Informar aos consumidores sobre } \\
\text { as ações dos produtores em } \\
\text { busca de reduzir o impacto } \\
\text { ambiental da produção de suínos. }\end{array}$ \\
\hline $\begin{array}{l}\text { Para os produtos frescos, } \\
\text { pouco processados e mais } \\
\text { processados, as variáveis } \\
\text { que influenciam a satisfação } \\
\text { do consumidor são apenas o } \\
\text { sabor e as qualidades } \\
\text { saudáveis. }\end{array}$ & $\begin{array}{l}\text { Confirma-se que, no } \\
\text { item alimentos, o } \\
\text { sabor ainda influencia } \\
\text { bastante a escolha; a } \\
\text { saúde tem se tornado } \\
\text { cada vez mais } \\
\text { importante. }\end{array}$ & 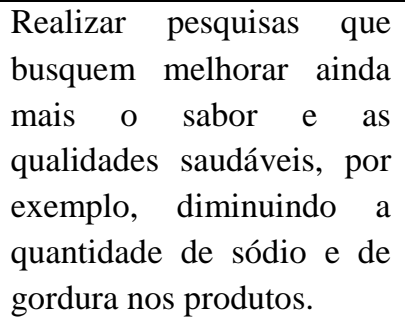 & $\begin{array}{lcc}\text { Lançar } & \text { novos } & \text { produtos } \\
\text { enfatizando } & \text { no } & \text { marketing o } \\
\text { aumento } & \text { suas } & \text { qualidades } \\
\text { saudáveis. } & & \\
\end{array}$ \\
\hline $\begin{array}{l}\text { Para as refeições, há } \\
\text { influência das qualidades } \\
\text { saudáveis, sabor e preço na } \\
\text { satisfação } \\
\text { consumidores. }\end{array}$ & $\begin{array}{lr}\text { Os } & \text { atributos } \\
\text { preferidos } & \text { pelos } \\
\text { consumidores não são } \\
\text { os mesmos para todos } \\
\text { os produtos. }\end{array}$ & $\begin{array}{l}\text { Além do exposto no item } \\
\text { anterior, realizar estudos } \\
\text { para que o preço dos } \\
\text { produtos não seja } \\
\text { aumentado em virtude da } \\
\text { inclusão ou melhora nos } \\
\text { atributos dos produtos. }\end{array}$ & $\begin{array}{l}\text { Além do exposto no item } \\
\text { anterior, cuidar para que o preço } \\
\text { dos produtos seja compatível } \\
\text { com suas qualidades e com o de } \\
\text { seus concorrentes, em especial as } \\
\text { outras proteínas. }\end{array}$ \\
\hline $\begin{array}{l}\text { Produtos de carne são } \\
\text { influenciados pelo sabor e } \\
\text { pela facilidade de preparo. }\end{array}$ & 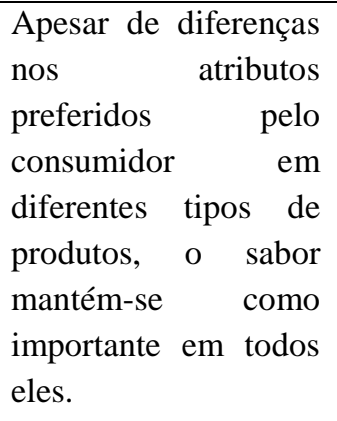 & $\begin{array}{l}\text { Confirma-se a tendência } \\
\text { mundial para alimentos em } \\
\text { geral, de busca por } \\
\text { alimentos de preparo fácil } \\
\text { e rápido. Assim, é } \\
\text { importante que se } \\
\text { desenvolvam produtos } \\
\text { com esse atributo. }\end{array}$ & $\begin{array}{l}\text { Mostrar aos consumidores essas } \\
\text { qualidades dos produtos, e } \\
\text { informá-los das maneiras de } \\
\text { preparo. }\end{array}$ \\
\hline $\begin{array}{l}\text { Arroz é o acompanhamento } \\
\text { mais citado pelos } \\
\text { entrevistados para os } \\
\text { produtos suínos. }\end{array}$ & $\begin{array}{l}\text { Os consumidores têm } \\
\text { poucas opções de } \\
\text { acampanhamento } \\
\text { específico para } \\
\text { produtos de carne } \\
\text { suína. }\end{array}$ & $\begin{array}{l}\text { Realizar maiores e mais } \\
\text { profundas pesquisas com o } \\
\text { consumidor final a fim de } \\
\text { investigar mais a fundo } \\
\text { quais seriam suas } \\
\text { preferências de consumo. }\end{array}$ & $\begin{array}{l}\text { Mostrar aos consumidores as } \\
\text { opções de acompanhamento para } \\
\text { os produtos, e criar embalagens } \\
\text { onde eles sejam vendidos juntos: } \\
\text { o produto de carne e o } \\
\text { acompanhamento. }\end{array}$ \\
\hline
\end{tabular}




\section{CONCLUSÕES}

A proposta desta tese foi aprofundar o conhecimento a respeito de como se comportam os consumidores de carne suína no Brasil com relação às maneiras e preferências de compra e consumo (onde compram, como compram, onde consomem, na companhia de quem consomem, com que frequência consomem, como preparam). Descobriu-se que os produtos pesquisados têm um bom nível de penetração entre os consumidores da amostra, o que indica que são conhecidos, mas não necessariamente que sejam consumidos. Porém isso confirma o conceito de que a carne suína é aceita pelos consumidores e que seu consumo não é mais alto por fatores culturais e também de disponibilização dos produtos nos pontos de venda, falta de variedade de cortes e de produtos processados, entre outros.

Também foi analisada a satisfação do consumidor com o produto em geral, com seu sabor, suas características em relação à saúde do consumidor, a facilidade de preparo ou conveniência, o preço, além de com quais outros alimentos a carne suína combina no momento do consumo. Daí pôde-se perceber que, apesar de o consumidor estar satisfeito com o produto em geral, poderiam ser melhorados os aspectos preço, saúde e conveniência, sendo sabor o atributo no qual o consumidor encontra mais satisfação ao consumir o produto.

Outro aspecto investigado pela pesquisa foi a visão que o consumidor tem sobre a produção de suínos e os impactos dessa visão no consumo da carne suína e de seus derivados. Assim como os resultados obtidos na pesquisa realizada na Europa, percebeu-se que existe pouca relação entre essa visão e o consumo propriamente dito. Ou seja, o que o consumidor pensa a respeito da produção de suínos tem pouca influência no consumo do produto.

Além disso, buscou-se investigar a relação entre o estilo de vida dos consumidores e o consumo dos produtos pesquisados. Descobriu-se aqui que, assim como em relação à produção de suínos, o consumo tem baixa relação com o estilo de vida dos consumidores, de acordo com a escala utilizada $(F R L)$. Dentre as dimensões investigadas:

- Maneiras de comprar;

- Métodos de cozinhar;

- Aspectos de qualidade;

- Situação de consumo; 
- Motivos de compra, tem-se como resultados principais que:

- Os fatores 'relação preço/qualidade', 'segurança' e 'critério de preços' são os mais importantes - consumidores são conscientes quanto ao preço e tradicionais na sua maneira de se alimentar.

- 'Frescor' e 'importância de informações sobre o produto', 'relacionamentos sociais', 'sabor' e 'saúde' também representam fatores importantes.

Em termos de confiabilidade da escala, os itens 'produtos orgânicos', 'lojas especializadas', 'lista de compras' e 'evento social’ obtiveram níveis satisfatórios.

Buscou-se também relacionar as atitudes e valores dos consumidores de carne suína e o consumo, separando os produtos em frescos e processados, divindo a análise da amostra entre os gêneros (masculino e feminino) e por idades. Alguns resultados interessantes foram encontrados, como a relação positiva entre produtos processados e a atitude favorável em relação à produção industrial. Ou ainda a relação negativa entre o consumo de alimentos frescos e valores de "liberdade" e "hedonismo", mostrando que possivelmente pessoas com esses valores prefiram alimentos mais fáceis e rápidos de preparar a fim de ter tempo disponível para suas atividades de lazer, o que não é o caso dos produtos frescos. Resultados gerais:

- Atitude positiva com relação à produção industrial de alimentos - consumo de produtos processados

- Valores 'estímulo', 'realização' e 'hedonismo' - consumidores tendem a evitar produtos frescos

- Quanto maior o grau de escolaridade - maior o consumo de processados

- Valores 'conformidade', 'poder' e 'segurança' - entrevistados da amostra tendem a evitar produtos processados

- Teste de diferenças entre IMC e cidades não apresentaram resultados significativos

- Consumo da região Sul é maior que das outras regiões

Foram comparados os resultados encontrados em diferentes regiões do Brasil, tendo-se encontrado poucas diferenças significativas entre eles. 
O trabalho atingiu os objetivos a que se propôs, mesmo que os resultados encontrados não tenham sido exatamente os esperados. A impossibilidade de validação de alguns dos construtos utilizados não invalida os resultados obtidos de maneira geral.

Também, a hipótese da pesquisa, exposta no capítulo 4, não se confirmou. Segundo ela, as atitudes dos consumidores brasileiros de carne suína em relação ao meio ambiente e à natureza, à produção industrial de alimentos, ao progresso tecnológico e ao etnocentrismo seriam influenciadas pelos conceitos do $F R L$ e $P V Q$. Tanto essas atitudes, quanto os próprios conceitos de FRL e $P V Q$ influenciariam a maneira como o consumidor vê a produção de suínos; tudo isto somado, seriam gerados os comportamentos de consumo do consumidor final de carne suína no Brasil. Foi encontrada uma baixa relação entre os construtos pesquisados e o consumo de carne suína.

A utilização da TPB como parte da base teórica é também um importante aspecto do estudo, uma vez que, conforme observado no capítulo 2, ainda existem poucos que utilizam esta teoria utilizando como objeto de análise o conportamento do consumidor de carne suína.

\subsection{Limitações e Contribuições}

Toda pesquisa de caráter acadêmico deve ser considerada dentro das limitações da metodologia utilizada. No presente estudo, um importante fator limitador foi o pequeno tamanho da amostra. No contexto brasileiro, uma amostra de 480 respondentes dividida em quotas de idade, gênero e região torna-se um tanto restrita. Tentou-se minimizar esse problema restringindo a aplicação a apenas duas regiões do país. De qualquer maneira, porém, os resultados não podem ser generalizados para toda a população brasileira.

Além disso, por se estar realizando a replicação de uma pesquisa internacional comparativa entre diferentes culturas (cross-cultural), deve-se estar ciente de que o contexto inicial pode não ser compatível com o novo contexto que se está analisando. Por isso mesmo são tão importantes e necessárias as etapas de adaptação, validação e testes do instrumento de pesquisa.

Ainda assim, trata-se de um importante indicador de tendências gerais de consumo. Pela velocidade das mudanças por que passa o consumidor de alimentos e da transmissão de 
informações entre diferentes países, pode-se prever que as tendências de consumo nos países desenvolvidos sejam rapidamente transformadas em realidade nos outros países.

Uma importante contribuição acadêmica foi a replicação de uma pesquisa internacional crosscultural. Steenkamp e Baumgartner (1998) e Netemeyer et al (1991) afirmam ser crucial que modelos desenvolvidos em um país possam ser estendidos a outros, não esquecendo o cuidado com a equivalência de construtos, amostra e mensuração.

Outra contribuição do trabalho foi a realização de uma pesquisa empírica com o consumidor final de alimentos. Conforme citado no decorrer do trabalho, trata-se de uma área bastante carente de pesquisas acadêmicas (MACHADO FILHO, 2000; GARCIA; BLISKA, 2000; BRISOLA; CASTRO, 2005; BARCELLOS, 2007; SILVA, 2009) que indiquem tendências ou ofereçam "pistas" sobre o comportamento do consumidor de carne suína, suas preferências, formas de compra e de consumo, a maneira como o consumidor vê a produção de suínos em seus diferentes papéis, tanto como consumidor quanto como cidadão, e especialmente como isso tudo afeta o consumo efetivo dos produtos.

\subsection{Sugestões}

Uma importante sugestão para pesquisas futuras seria um trabalho que efetivamente comparasse os resultados obtidos no Brasil com os obtidos na Europa e em especial na China, que entrou no projeto Q-PorkChains como o outro país externo, além do Brasil. Em um dos resultados do Projeto, foram feitas análises comparativas entre os países europeus nos itens relativos a frequência de consumo, porém há uma enorme quantidade de informações ainda não analisadas, tanto obtidas na amostra brasileira quanto em termos de comparações entre os países.

É muito importante para as empresas dos países produtores, como o Brasil, obterem dados sobre os consumidores dos países desenvolvidos, uma vez que, além de importantes consumidores de nossos produtos, por meio da exportação, são indicadores de tendências de consumo, o que hoje é rapidamente disseminado globalmente. Somente conhecendo os consumidores, sabendo o que desejam nos produtos que consomem, de que maneira consomem, onde, com quem, quão satisfeitos estão com os produtos consumidos, os produtores poderão oferecer-lhes aqueles que serão aceitos e que voltarão a ser consumidos por eles. 
Seria muito importante também a realização de uma pesquisa nos moldes desta, porém com uma seleção um pouco diferente de tópicos, que incluísse, por exemplo, uma seção sobre aspectos culturais influenciando o consumo de alimentos, hábitos de consumo ou mudanças na renda dos consumidores. Também, que fosse aplicada a uma amostra maior de respondentes. Poderiam ser incluídas amostras nos grandes centros do Brasil, onde certamente tem-se um perfil de consumidores bastante diferente em termos de estilo de vida e percepções sobre a produção de suínos. Por estarem bastante distantes da produção, os consumidores dos grandes centros urbanos possivelmente não relacionam o alimento que encontram à disposição no ponto de venda com o animal criado nas propriedades rurais, com os quais provavelmente nunca tiveram contato.

Outra sugestão refere-se à replicação desta pesquisa para outros produtos que não a carne suína. Além de validar os instrumentos, poder-se-iam descobrir importantes aspectos sobre o consumidor desses alimentos. 


\section{REFERÊNCIAS}

AAKER, David A. Marcas - Brand Equity: Gerenciando o valor da marca. São Paulo: Negócio, 1998.

; JOACHIMSTHALER, Erich.Como construir marcas líderes. São Paulo: Futura, 2000.

. Strategic market management. $6^{\text {th }}$ ed. Berkeley (CA): John Wiley \& Sons, 2001.

AGÊNCIA BRASIL. 2010. Disponível em: 〈http://www.ebc.com.br〉. Acesso em: 05 out. 2010.

2001.

Nature and operation of attitudes. Annual Review of Psychology, v. 52, p. 27-58,

; FISHBEIN, Martin. Understanding attitudes and predicting social behavior. Englewood Cliffs, New Jersey: Prentice-Hall, 1980.

; Attitudes and the attitude-behavior relation: Reasoned and automatic processes. In STROEBE, W.; HEWSTONE, M. (Eds.). European Review of Social Psychology. John Wiley \& Sons, p. 1-33, 2000.

. Constructing a TPB Questionnaire: Conceptual and methodological considerations. mimeo. Disponível em: <http://www-unix.oit.umass.edu/ aizen/tpb.html>. Revisado em Janeiro, 2006. Brief Description of the Theory of Planned Behavior, 2002.

ALMEIDA, Marco Antonio Bettine de et al. Comentários sociológicos da cultura alimentar. In: MENDES, Roberto Teixeira et al (Orgs.). Qualidade de vida e cultura alimentar. Cap. 6. Campinas: Ipes Editorial, 2009. Disponível em: <http://www.fef.unicamp.br/departamentos/deafa/qvaf/livros/foruns_interdisciplinares_saude/cul tura/cultura_alimentarcap6.pdf $>$. Acesso em: 13 nov. 2010.

ALTMANN, Roberto. A agricultura familiar e os contratos: reflexões sobre os contratos de integração, a concentração da produção e a seleção de produtores. Florianópolis: Palotti, 1997. $112 \mathrm{p}$.

ALVES, Maria Rita Pontes Assumpção. Logística agroindustrial. In: BATALHA, Mário Otávio. Gestão agroindustrial. São Paulo: Atlas, 1997.

ANTONIDES, Gerrit; VAN RAAIJ, W. Fred. Consumer behavior: a European perspective. England: John Wiley \& Sons, 1998. 617 p.

ANUÁRIO DA PECUÁRIA BRASILEIRA - ANUALPEC. São Paulo: Instituto FNP, 2009.

ARAÚJO, Ney Bittencourt et al. Complexo agroindustrial: o agribusiness brasileiro. São Paulo: Agroceres, 1990. 
ARGUMENTO SUÍNO. Carne suína: agora com os olhos só para o cliente. Brasília, ano I, n. 6, 2006.

ASKEGAARD, S.; BRUNSO, Karen. Food-related life styles in Singapore: Preliminary testing of a Western European research instrument in Southeast Asia. Journal of Euromarketing, v. 7 , p. 65-86, 1999.

ASSOCIAÇÃO BRASILEIRA DA INDÚSTRIA PRODUTORA E EXPORTADORA DE CARNE SUÍNA - ABIPECS. Carne suína: a conquista do mercado interno. Brasília: março, 2009.

- Relatório anual ABIPECS 2007. Disponível em <http://www.abipecs.org.br/relatorios/ABIPECS_relatorio_2007_en.pdf>. Acesso em: 20 jun. 2008.

. Relatório anual ABIPECS 2008. Disponível em <http://www.abipecs.org.br/relatorios/ABIPECS_relatorio_2008_en.pdf>. Acesso em: 10 ago. 2009.

$\begin{array}{lllll} & \text { Relatório anual } & \text { ABIPECS } & 2009 . & \text { Disponível em }\end{array}$ <http://www.abipecs.org.br/relatorios/ABIPECS_relatorio_2009_en.pdf>. Acesso em: 20 jun 2010.

. Relatório anual ABIPECS 2010. Disponível em <http://www.abipecs.org.br/relatorios/ABIPECS_relatorio_2010_en.pdf>. Acesso em: 06 ago. 2010.

Página institucional. Disponível em <http://www.abipecs.com.br>. Vários Acessos.

BAPTISTA, Paulo de Paula. Lealdade do consumidor e os seus antecedentes: um estudo aplicado ao setor varejista na internet. São Paulo. 2005. Tese (Doutorado em Administração) Programa de Pós-Graduação em Administração, Departamento de Administração da Faculdade de Administração, Economia e Contabilidade da Universidade de São Paulo.

BARCELlOS, Márcia Dutra de. Processo decisório de compra de carne bovina na cidade de Porto Alegre. Porto Alegre. 2002. Dissertação (Mestrado em Agronegócios) - Programa de PósGraduação em Agronegócios da Universidade Federal do Rio Grande do Sul.

Beef lovers: um estudo cross-cultural sobre o comportamento de consumo de carne bovina. Porto Alegre. 2007. Tese (Doutorado em Agronegócios) - Programa de Pós-Graduação em Agronegócios da Universidade Federal do Rio Grande do Sul.

et al. New consumer approach: understanding emotions and involvement in beef consumption. In: INTERNATIONAL AGRIBUSINESS MANAGEMENT ASSOCIATION CONFERENCE - IAMA. Proceedings... Chicago, 2005. 
et al. Food innovation: Perspectives for the poultry chain in Brazil. In: INTERNATIONAL CONFERENCE ON MANAGEMENT IN AGRIFOOD CHAINS AND NETWORKS, 8., 2008, Wageningen. Proceedings... Wageningen: Wageningen Academic Publishers, 2008.

et al. Attitudes of Brazilian citizens towards pig production systems: a comparison with European realities. In: INTERNATIONAL PENSA CONFERENCE, 7., 2009, São Paulo. Proceedings... São Paulo, 26-28 novembro, 2009.

et al. Investigating the gap between citizens' sustainability attitudes and food purchasing behaviour: empirical evidence from the Brazilian pork consumers. Submetido ao International Journal of Consumer Studies, 2010.

BARROS, Alexandre Mendonça de. A nova classe média brasileira. Revista DBO Rural, p. 28, set 2010 .

BATALHA, Mário Otávio; SILVA, Andrea Lago da. Gerenciamento de sistemas agroindustriais In: BATALHA, Mário Otávio. Gestão agroindustrial. 3. ed. São Paulo: Atlas, 2007. p. 1-64.

BEARDEN, W. O.; TEEL, J. E. Selected determinants of consumer satisfaction and complaint reports. Journal of Marketing Research, v. 20, p. 21-28, 1983.

BECKMANN, Suzanne C. et al. Danish consumers and organic foods. Copenhagen: Copenhagen Business School, 2001.

BERNDSEN, Mariette; PLIGT, Joop van der. Ambivalence towards meat. Appetite, v. 42, p. 7178, 2004.

BERNUÉS, A. et al. Labelling information demanded by European consumers and relationship with purchasing motives, quality and safety of food. Meat Science, 65, 1095-1106.

BONNE, Karijn et al. Determinants of halal meat consumption in France. British Food Journal, v. 109, n. 5, p. 367-386, 2007.

et al. Determinants of halal meat consumption in Belgium. Journal of International

Food and Agribusiness Marketing. v. 21, n. 1, p. 5-26, Jan. 2009.

BOONE, Louis E.; KURTZ, David L. Marketing contemporâneo. Rio de Janeiro: LTC, 1998.

BORRÁS, Miguel Angel; TOLEDO, José Carlos. A coordenação de cadeias agroindustriais In: ZUIN, Luis Fernando Soares; QUEIROZ, Timóteo Ramos. Agronegócios gestão e inovação. São Paulo: Saraiva, 2006. p. 23-50.

BRAGAGNOLO, Neusa; RODRIGUEZ-AMAYA, Délia. Teores de colesterol, lipídios totais e ácidos graxos em cortes de carne suína. Campinas: Faculdade de Engenharia de Alimentos Universidade de Campinas (Unicamp), 2001. 
BRASIL. Ministério da Agricultura, Pecuária e Abastecimento. Assessoria de Gestão Estratégica (AGE). Projeções do Agronegócio Brasil 2009/2010 a 2019/2020. Brasília, fev. 2010.

. Suínos. Disponível em: <http://www.agricultura.gov.br/portal/page/portal/InternetMAPA/pagina-inicial/animal/especies/suinos>. Acesso em: 10 jan. 2011.

- Ministério do Desenvolvimento, Indústria e Comércio Exterior. Carne Suína: a conquista do mercado interno. Brasília, março 2009.

BREDAHL, Lone et al. Food-related lifestyle in Spain (MAPP project paper). Aarhus: The Aarhus School of Business, 1996.

BRISLIN, Richard W. Back-translation for cross-cultural research. Journal of Cross-cultural Psychology, v. 1, p. 185-216, 1970.

BRISOLA, Marlon Vinícius; CASTRO, Antônio Maria Gomes de. Preferências do consumidor de carne bovina do Distrito Federal pelo ponto de compra e pelo produto adquirido. Revista de Gestão USP. REGE-USP, São Paulo, v. 12, n. 1,: mar. 2005. Disponível em: <http://www.revistasusp.sibi.usp.br/scielo $>$. Acesso em: 28 maio 2010.

BROWN, Kelly McCormack. Theory of Reasoned Action/Theory of Planned Behaviour. University of South Florida. 1999. Disponível em: <http://hsc.usf.edu/ kmbrown/TRA_TPB.htm>. Acesso em: dia abr. 2010.

BRUNSO, Karen; GRUNERT, Klaus G. Development and testing of a cross-culturally valid instrument: Food-related lifestyle. Advances in Consumer Research. v. 22, p. 475-480, 1995.

; _ Cross-cultural similarities and differences in shopping for food. Journal of Business Research. v. 42, p. 145-150, 1998.

; Consumer attitude measures and food product development. In: MacFIE, H. (Ed.), Consumer-led food product development. Cambridge: Woodhead Publishing, 2007. p. 197-222.

et al. Testing relationships between values and food-related lifestyle: results from two European countries. Appetite. v. 43, p. 195-205, 2004.

CALEMAN, Sílvia. Falhas de coordenação em sistemas agroindustriais complexos: uma aplicação na agroindústria da carne bovina. São Paulo, 2010. Tese (Doutorado em Administração) - Departamento de Administração da Faculdade de Economia, Administração e Contabilidade da Universidade de São Paulo.

CAMARGO, Pedro. Neuromarketing: descodificando a mente do consumidor. Porto, Portugal: Instituto Português de Administração de Marketing. Jun, 2009. 147 p.

CAMARGO NETO, Pedro. O desafio de ampliar o mercado externo. Disponível em $<$ http://www.abipecs.org.br/news/62/97/O-desafio-de-ampliar-o-mercado-externo.html>. Acesso em 16 nov. 2010. 
CANAL DO PRODUTOR. 2011. Disponível em: <http://www.canaldoprodutor.com.br/comunicacao/noticias/campanha-pretende-aumentarconsumo-de-carne-suina-no-brasil>. Acesso em: 10 jan. 2011.

CANTON, Adolpho W. P. et al. Avaliando os níveis de envolvimento dos consumidores. In: ENCONTRO ANUAL DA ASSOCIAÇÃO NACIONAL DE PÓS-GRADUAÇÃO EM ADMINISTRAÇÃO - ENANPAD, 1989, Belo Horizonte. Anais... p. 741-752, Belo Horizonte, setembro de 1989.

CARTILHA ABCS. Associação Brasileira dos Criadores de Suínos (2006). Disponível em: <http://www.abcs.org.br/portal/mun_car/marketing/novo_olhar/index.jsp>. Acesso em: 15 mar. 2009.

CARVALHO, Thiago Bernardino de. Estudo da elasticidade-renda da demanda de carne bovina, suína e de frango no Brasil. Dissertação (Mestrado em Economia Aplicada). Universidade de São Paulo. Piracicaba - SP. 2007.

CARVALHO-ROCHA, Josyanne C. Marajó de et al. Experiências com alianças verticais na coordenação da cadeia produtiva da carne bovina no Brasil. In: CONGRESSO INTERNACIONAL DE ECONOMIA E GESTÃO DE NEGÓCIOS, 3., 2001, Ribeirão Preto. Anais... Ribeirão Preto: FEA-USP, 2001.

CASOTTI, Letícia Moreira. Comportamento do consumidor de alimentos: adoção de novos produtos e riscos associados. In: ENCONTRO NACIONAL DA ASSOCIAÇÃO NACIONAL DE PÓS-GRADUAÇÃO EM ADMINISTRAÇÃO - ENANPAD, 2001, Campinas. Anais... Campinas, 2001.

CEPEA/ESALQ/USP. Pib_Cepea_1994_2009. Disponível em: <http://www.cepea.esalq.usp.br/pib/>. Acesso em: 15 out 2010.

CEPEA-ESALQ/USP. Boletim do suíno. Ano 1, n. 1, out. 2010.

CHIUSOLI, Cláudio Luiz et al. Comportamento do consumidor e as contribuições do modelo estímulo e resposta na orientação das ações de marketing: um estudo dirigido para produto de uso feminino. SEMINÁRIOS EM ADMINISTRAÇÃO - SEMEAD, 7., 2008, São Paulo. Anais... São Paulo: $\quad$ FEA/USP, 2008. Disponível em: $<$ http://www.ead.fea.usp.br/Semead/7semead/MKT21_Comportamento_consumidor_est_dirig_P rod.PDF>. Acesso em: 14 ago. 2010.

CHURCHILL, Gilbert A. Jr. Marketing research: methodological foundations. London: The Dryden Press, 1991.

CHURCHILL, Gilbert A. Jr.; PETER, Paul J. Marketing: criando valor para os clientes. 2. ed. São Paulo: Saraiva, 2000.

CONSOLI, Matheus Alberto et al. An analysis of the Brazilian meat chain: structure, features and quantification. In: INTERNATIONAL FOOD AND AGRIBUSINESS MANAGEMENT ASSOCIATION SYMPOSIUM, 20., 2010, Boston. Proceedings... 2010, Boston. 
CORNÉLIO, Marília Estevam et al. Desenvolvimento e confiabilidade de instrumento para mensuração dos fatores psicossociais determinantes do consumo de sal entre hipertensos. Revista Latino-Americana de Enfermagem. Ribeirão Preto, v.17, n. 5, p. 701-707, set./out. 2009.

CUNHA, Lilian. No churrasco da crise, linguiça rouba espaço da picanha. Jornal Valor Econômico. 21 jan. 2009.

CZINKOTA, Michael R. Marketing: as melhores práticas. Porto Alegre: Bookman, 2001.

DAHER, Eduardo. A agricultura que o Brasil almeja. Folha de S.Paulo. São Paulo, 03 set. 2010. Disponível em: <http://porkworld.com.br/artigos/post/a-agricultura-que-o-brasil-almeja〉. Acesso em: 14 set. 2010.

DALLARI, Milton. Demandas do consumidor final e como o varejo vê o mercado. International Meat Congress. São Paulo, Maio 2007. CD-ROM.

DARBY, K. et al. Decomposing local: a conjoint analysis of locally produced foods. American Journal of Agricultural Economics. v. 90, p. 476-486, 2008.

DAVIS, John H.; GOLDBERG, Ray A. A concept of agribusiness. Boston: Division of Research. Graduate School of Business Administration. Harvard University, 1957. 136 p.

DESOUZART, Osler. Várias comunicações pessoais, 2009 e 2010.

DONEGÁ, Ricardo Angelotti. Atitudes em relação a sites de leilão online: um estudo exploratório com internautas brasileiros. São Paulo, 2004. Dissertação (Mestrado em Administração) - Faculdade de Economia, Administração e Contabilidade da Universidade de São Paulo.

DOUGLAS, Evan J. Managerial economics: analysis and strategy. 4. ed., USA: Prentice Hall, 1992.

DUNLAP, Riley E. et al. Measuring endorsement of the new ecological paradigm: a revised NEP scale. Journal of Social Issues. n. 3, v. 56, p. 425-442, 2000.

ECKHARDT, Octávio Henrique Orlovsky. et al. Iniciativas do sistema agroindustrial da carne suína para sinalizar excelência. Pork World, ed. 46, 2009. Disponível em: <www.porkworld.com.br〉. Acesso em: 15 abr. 2009.

ELMADFA, Ibrahim; WEICHSELBAUM, Elisabeth. On the nutrition and health situation in the European Union. Journal of Public Health. n. 2, v. 13, p. 62-68, Feb 2005.

ENGEL, James F. et al. Consumer behavior. 8th. ed. Forth Worth: The Dryden, 1995. 995 p. . Comportamento do consumidor. Rio de Janeiro: LTC, 2000. 
FARIA, I. G. et al. Mercado consumidor de carne suína e derivados em Belo Horizonte. Arquivo Brasileiro de Medicina Veterinária e Zootecnia. Belo Horizonte, n. 2, v. 58, abr. 2006.

FARINA, Elizabeth Maria Mercier Querido; ZYLBERSZTAJN, Decio. Competitividade e organização das cadeias agroindustriais. São Paulo: PENSA/FIA/FEA/USP, 1993.

et al. Competitividade: mercado, estado e organizações. São Paulo: Singular, 1997.

. Consolidation, multinationalisation and competition in Brazil: impacts on horticulture and dairy products systems. Development Policy Review. Oxford, v. 20, n. 40, p. 441-458, 2002.

FAVERET FILHO, Paulo; SIFFERT FILHO Nelson. O sistema agroindustrial de carnes: competitividade e estruturas de governança. In: SEMINÁRIO SOBRE COMPETITIVIDADE NA INDÚSTRIA DE ALIMENTOS, 1998, Campinas. Anais... Campinas, 1998.

FERREIRA, Gabriela Cardozo; BARCELLOS, Márcia Dutra de. Alianças estratégicas em cadeias agroindustriais: estudo de caso na cadeia da carne bovina. In: ENCONTRO NACIONAL DA ASSOCIAÇÃO NACIONAL DE PÓS-GRADUAÇÃO EM ADMINISTRAÇÃO ENANPAD, 28., 2004, Curitiba. Anais... Curitiba: ANPAD, 2004.

FILA, Stephanie; SMITH, Chery. Applying the Theory of Planned Behavior to healthy eating behaviors in urban Native American youth. International Journal of behavioral nutrition and Physical activity. v. 3, 2006.

FISHBEIN, Martin; AJZEN, Icek. Belief, attitude, intention and behavior: an introduction to theory and research. Boston: Addison-Wesley, 1975.

; MIDDLESTADT, Susan. Noncognitive effects on attitude formation and change: fact or artifact? Journal of Consumer Psychology. v. 4, p. 181-202, 1995.

GARCIA, Renato Ferraz, BLISKA, Flávia Maria de Mello. Caracterização do consumo de carnes no Brasil. Revista Nacional da Carne. São Paulo, Ano XXV, n. 284, p. 108-109, out. 2000 .

GEISINGER, K.F. Cross-cultural normative assessment: translation and adaptation issues influencing the normative interpretation of assessment instruments. Psychological Assessment, v. 6, n. 4, p. 304-312, 1994.

GEORGE, D., MALLERY, P. SPSS for Windows step by step: a simple guide and reference. 4th ed. Boston: Allyn \& Bacon, 2003.

GIL, Antonio Carlos. Como elaborar projetos de pesquisa. 4. ed. São Paulo: Atlas, 2006.

GOLDBERG, Ray A. Agribusiness coordination. Boston: Harvard University, 1968. 
GREENWALD, A. G. Why are attitudes important? In: PRATKANIS, A. R.: BRECKLER, S. J.: GREENWALD, A. G. (Eds.). Attitude structure and function. Hillsdale, NJ: Erlbaum, 1989. p. 1-10.

GRUNERT, Klaus. What's in a steak? A cross-cultural study on the quality perception of beef. Food Quality and Preference. Great Britain, n. 3, v. 8, p. 157-174, 1997. $176,1995$.

Food quality: a means-end perspective. Food Quality and Preference. v. 6, p. 171Current issues in the understanding of consumer food choice. In: INTERNATIONAL CONFERENCE ON AGRI-FOOD CHAIN/NETWORKS ECONOMICS AND MANAGEMENT, 3., 2001, Ribeirão Preto, SP. Proceedings... Ribeirão Preto: PENSA, 2001, p. 13-33.

Current issues in the understanding of consumer food choice. Trends in Food Science \& Technology. n. 8, v. 13, p. 275-285, 2002.

Food quality and safety: consumer perception and demand. European Review of Agricultural Economics. n. 3, v. 32, p. 369-391, 2005.

Future trends and consumer lifestyles with regard to meat consumption. Meat Science. v. 74, n. 1, p. 149-160, 2006.

How changes in consumer behaviour and retailing affect competence requirements for food producers and processors. Economía y Recursos Naturales. v. 6, n. 11, p. 3-22, 2007.

Consumer trends and markets: attaining competitive advantage on European food markets. Promoting Agro-Food Industry Competitiveness. Ljubljana, Eslovenia, June 2008. Disponível em: <http:www.ec.europa.eu/enterprise/sectors/food/files/...2008/klausgfrunert_en.pdf>. Acesso em: maio 2010.

GRUNERT, KLAUS et al. Food-related lifestyle: development of a cross-culturally valid instrument for market surveillance. In KAHLE, L.; CHIAGOURIS, C. (Eds.), Values, lifestyles, and psychographics. Mahwah, NJ: Erlbaum, 1997. p.337-354.

Three issues in consumer quality perception and acceptance of dairy products. International Dairy Journal. v. 10, p. 575-584, 2000.

Food-related lifestyle: a segmentation approach to European food consumers. In: FREWER,Lynn J. E. et al. Food, people and society: an European perspective of consumers' food choices. London: Springer Verlag, 2001. p. 211-230.

Consumer perception of meat and quality implications for product development in the meat sector - a review. Meat Science. v. 66, p. 259-272, 2004.

HAIR JR., Joseph F. et al. Multivariate data analysis. New Jersey: Prentice Hall, 1998. 
. Multivariate data analysis. 6th ed. Upper Saddle River, NJ: Prentice-Hall, 2006. 897p.

HAMSTRA, Anneke M. Biotechnology in foodstuffs: towards a model of consumer acceptance. Den Haag: Swoka, 1991.

HAWKINS, Del I. et al. Comportamento do consumidor: construindo a estratégia de marketing. Rio de Janeiro: Elsevier, 2007.

HOEK, Annet C. et al. Food-related lifestyle and health attitudes of Dutch vegetarians, nonvegetarian consumers of meat substitutes, and meat consumers. Appetite. v. 42, p. 265-272, 2004.

HOPPE, Alexia. Comportamento do consumidor de produtos orgânicos em Porto Alegre em dois canais de distribuição. São Leopoldo, 2010. Dissertação (Mestrado em Administração) Programa de Pós-Graduação em Administração da Unidade Acadêmica de Pesquisa e PósGraduação da Universidade do Vale do Rio dos Sinos.

HOUSTON, John. Field to Plate. Palestra proferida no Congresso Del Campo al Plato, Montevideo, Uruguai, 23 e 24 nov. 2004. Organização LATU/INIA/INAC. Apresentação em Power Point.

INSTITUTO BRASILEIRO DE GEOGRAFIA E ESTATÍSTICA - IBGE. Banco de dados agregados. Disponível em: <http://www.sidra.ibge.gov.br/bda/>. Acesso em: 28 maio 2008.

. Países. Disponível em: 〈http://www.ibge.gov.br/paisesat>. Acesso em: 16 nov. 2010.

JANK, Marcos Sawaya. Competitividade do agribusiness brasileiro: discussão teórica e evidências no sistema carnes. São Paulo, 1996. Tese (Doutorado em Administração) - Programa de Pós-Graduação em Administração, Departamento de Administração, Faculdade de Economia, Administração e Contabilidade da Universidade de São Paulo.

JUNG, Carl. Tipos psicológicos. Rio de Janeiro: Zahar, 1974.

KAPLINSKI, Raphael; MORRIS, Mike. A handbook for value chain research. Brighton: Institute of Development Studies (IDS), 2003.Disponível em: <http://www.ids.ac.uk/ids/global/pdfs/VchNov01.pdf>. Acesso em: mar. 2006.

KARSAKLIAN, Elaine. Comportamento do consumidor. São Paulo: Atlas, 2000.

KATZ, K. The functional approach to the studies of attitudes. Public Opinion Quarterly. v. 24, p. 163-204, 1960. In PRATKANIS, A. R.; BRECKLER, S. J.; GREENWALD, A. G. (Eds.). Attitude, structure and function. Hillsdale, New Jersey: Lawrence Erlbaum, 1960. KEHAGIA, Olga et al. Marketing adaptation for large emerging markets comparing data from Europe, Brazil and China. Deliverable D I.1.11 Report comparing the data from Europe, Brazil and China. Documento interno do Projeto Integrado Q-PorkChains, 2010.

KESIC, Tanja; PIRI-RAJH, Suncana. Market segmentation on the basis of food-related lifestyles of Croatian families. British Food Journal. n.3, v. 105, p.162-174, 2003. 
KLINE, Rex B. Principles and practice of structural equation modeling. 2nd. ed. New York: The Guilford Press, 2005. 366 p.

KOTLER, Philip. Administração de marketing: análise, planejamento, implementação e controle. 5. ed. São Paulo: Atlas, 1998. Hall, 2000.

. Administração de marketing: a edição do novo milênio. 10. ed. São Paulo: Prentice Brasil, 1995.

; ARMSTRONG, Gary. Princípios de marketing. 7.ed. Rio de Janeiro: Prentice Hall do ; KELLER, Kevin Lane. Administração de marketing. 12. ed. São Paulo: Pearson Prentice Hall, 2006.

KRYSTALLIS, Athanasios et al. Attitudes of European citizens towards pig production systems. Livestock Science. v. 126, p. 46-56, 2009.

LARÁN, Juliano Aita; ESPINOZA, Francine da Silveira. Consumidores satisfeitos, e então? Analisando a satisfação como antecedente da lealdade. Revista de Administração Contemporânea. Curitiba, v. 8, n. 2, abr./jun. 2004.

LEVANTAMENTO SISTEMÁTICO DA PRODUÇÃO DE SUÍNOS - LSPS. EMBRAPA Suínos e Aves. 2009. Disponível em: <http://www.cnpsa.embrapa.br>. Acesso em: 06 abr. 2010.

LÉVI-STRAUSS, C. Les structures eléméntaires de la parenté. 2ème ed. Paris: Mouton, 1973.

LIANG, G. Social, culture and language barriers in the international Comparative survey research. Foundation Conference for the International Data Forum. Center for Social Development, Chinese Academy of Social Sciences, Beijing, June 5, 2007.

LINDEMAN, M.; VÄÄNÄNEN, M. Measurement of ethical food choices motives. Appetite. v. 4, p. 55-59, 2000.

LISTER, D. The meat we eat: notions of quality for today and tomorrow. Historical perspective and recent concerns. Outlook on Agriculture. v. 25, n. 3, p. 193-197, 1996.

MacBEAN, R. D. The changing global consumer. Food Technologist. v. 26, n. 2, p. 51-53, 1996.

MACHADO FILHO, Luiz Carlos Pinheiro. Bem-estar de suínos e qualidade da carne: uma visão brasileira. In CONFERÊNCIA INTERNACIONAL VIRTUAL SOBRE QUALIDADE DE CARNE SUÍNA, 1., 2000, Concórdia. Anais... Concórdia, 2000. p. 34-40.

MAHON, Denise; COWAN, Cathal; McCARTHY, Mary. The role of attitudes, subjective norm, perceived control and habit in the consumption of ready meals and takeaways in Great Britain. Food Quality and Preference. v. 17, p. 474-481, 2006. 
MALHOTRA, Naresh K. Pesquisa de marketing: uma orientação aplicada. Porto Alegre: Bookman, 2001.

MALHOTRA, Naresh K. Pesquisa de marketing: uma orientação aplicada. 4. ed. Porto Alegre: Bookman, 2006. 720 p.

MANEESRIWONGUL, W.; DIXON, J.K. Instrument translation process: a methods review. Journal of Advanced Nursing. v. 48, p.175-186, 2004.

MARCONI, Marina de Andrade; PRESOTTO, Zélia Maria Neves. Antropologia: uma introdução. São Paulo: Atlas, 2005.

MARKESTRAT - CENTRO DE PESQUISAS E PROJETOS EM MARKETING E ESTRATÉGIA. Mapping and quantification of the sausage meat chain in Brazil. Confidential Project Report. Ribeirão Preto, 2009.

MATTAR, Fauze Nagib. Pesquisa de marketing. São Paulo: Atlas, 2000.

McCARTHY, Mary et al. Factors influencing intention to purchase beef in the Irish market. Meat Science. v. 65, p. 1071-1083, 2003.

MCDANIEL, Carl; GATES, Roger. Pesquisa de marketing. São Paulo: Pioneira/ Thomson Learning, 2003.

MEDEIROS, Janine Fleith; CRUZ, Cassiana Maris Lima. Comportamento do consumidor: fatores que influenciam no processo de decisão de compra dos consumidores. Teoria e Evidência Econômica. Passo Fundo, v. 14, Ed. Especial, p. 167-190, 2006. Disponível em: <http://www.upf.br/cepeac/download/rev_esp_2006_art8.pdf >. Acesso em: 12 maio 2010.

MESTRINER, Fabio. Design de embalagem: curso básico. 2. ed. São Paulo: Makron Books, 2002.

MIELE, Marcelo. Contratos, especialização, escala de produção e potencial poluidor na suinocultura de Santa Catarina. Porto Alegre, 2006. Tese (Doutorado em Agronegócios) Programa de Pós-Graduação em Agronegócios, Universidade Federal do Rio Grande do Sul.

- Cadeia produtiva da carne suína no Brasil. In: INTERNATIONAL PENSA CONFERENCE, 6., 2007, Ribeirão Preto. Proceedings... Ribeirão Preto, Oct. 2007.

; MACHADO, Jurandi Soares. Levantamento Sistemático da Produção e Abate de Suínos - LSPS: metodologia ABIPECS-EMBRAPA de previsão e acompanhamento da suinocultura brasileira. Concórdia: Embrapa Suínos e Aves, 2006. 25 p. (Embrapa Suínos e Aves. Documentos, p. 104).

; WAQUIL, Paulo D. Cadeia produtiva da carne suína. Revista de Política Agrícola. v. 16, n. 1, p. 75, 2007. 
Estrutura e dinâmica dos contratos na suinocultura de Santa Catarina: um estudo de casos múltiplos. Estudos Econômicos. São Paulo, n. 4, v. 37, p. 817-847, out./nov./dez. 2007

; GIROTTO, Ademir Francisco. Transação entre suinocultor e agroindústria em Santa Catarina. Concórdia: Embrapa Suínos e Aves, 2006. 8 p. (Embrapa Suínos e Aves. Comunicado Técnico, 428).

A suinocultura brasileira em 2007 e cenários para 2008. Anuário 2008 da Suinocultura Industrial. n. 1, edição 211, ano 31, p. 14-22, 2008.

MILAN, Márcio. Relações institucionais - Carne de porco ou carne suína? SEMINÁRIO INTERNACIONAL DE AVES E SUÍNOS - AVESUI, 2008, Florianópolis, maio 2008.

MILLET, Sam et al. Welfare, performance and meat quality of fattening pigs in alternative housing and management systems: a review. Journal of Scientific Food Agriculture. v. 85, p.709-719, 2005.

MONTINI, Alexander Luis. Consumo de carne bovina: uma análise aplicada às redes varejistas, Londrina, Estado do Paraná. Informações Econômicas. São Paulo, v. 35, n. 10, out. 2005.

MORAES, Márcia Azanha Ferraz Dias de; MACEDO, Luiz Otávio Bau. Perfil de governança e a coordenação de alianças estratégicas do sistema agroindustrial da carne bovina brasileira. Informações Econômicas. São Paulo, n. 3, v. 39, mar. 2009.

MOURA, Luiz Eduardo Leite de et al. A percepção do consumidor acerca dos atributos da carne suína: um estudo com alunos de uma IES. Informe Gepec. Toledo, n. 2, v. 13, p. 37-53, jul./dez. 2009.

MOWEN, John. The art of high-stakes decision-making. New York: Wiley Press, 2002.

; MINOR, Michael S. Comportamento do consumidor. São Paulo: Prentice Hall, 2003.

MYERS, David. Psicologia social. Rio de Janeiro: LTC, 2000.

NASCIMENTO, Iderlan Soares do. O comportamento do consumidor: vamos entendê-lo? 2008.

Disponível em: <http://www.artigonal.com/gestao-artigos/o-comportamento-do-consumidorvamosentende-lo-576430.html > . Acesso em: 12 maio 2010.

NETEMEYER, Richard G. et al. A crossnational assessment of the reliability and validity of the CETSCALE. Journal of Marketing Research. v. 28, p. 320-327, Aug. 1991.

NEVES, Marcos Fava. Planejamento e gestão estratégica de marketing. São Paulo: Atlas, 2005. $230 \mathrm{p}$.

et al. Q-Pork Chains: Improving the quality of pork and pork products for the consumer: Development of innovative, integrated, and sustainable food production chains of high quality pork products matching consumer demands. Deliverable D.1.1.2 Pork Consumption in Europe and Beyond: Comprehensive Report. Part B: Pork Consumption in Brazil Documento Interno, 2008. 
et al. Marketing methods to improve company strategy: applied tools and frameworks to improve a company's competitiveness using a network approach. New York and London: Routledge, 2010.

et al. Gestão de negócios em alimentos. São Paulo: Pioneira, 2000.

et al. A model for the distribution channels planning process. Journal of Business and Industrial Marketing. Londres: MCB University Press, v. 16, n. 7, p.518-539, Nov. 2001.

et al. Marketing e o novo consumidor de alimentos. 2000. Disponível em: <http://www.usp.br/fearp/fundace/marketing/artigos/10.pdf>. Acesso em: 15 maio 2010.

NORTH, Douglass. Institutions, institutional change and economic performance. Cambridge: Cambridge University Press, 1990.

NOTÍCIAS FAESP/SENAR. Agricultura aprova preço mínimo para comercialização de carne suína. 02 dez. 2010.2 Disponível em: $<$ http://www.faespsenar.com.br/geral/noticias/detalhe/agricultura-aprova-preco-minimo-paracomercializacao-de-carne-suina/2585>. Acesso em: 10 jan. 2011.

NOVAES, Amilton Luiz et al. Efeito do nível de escolaridade no consumo de carne bovina e hortaliças no Brasil. In: CONGRESSO DA SOBER - Sociedade Brasileira de Economia e Sociologia Rural, 44., 2006, Fortaleza. Anais... Fortaleza, 23 a 27 jul. 2006.

OECD-FAO AGRICULTURAL OUTLOOK 2009. Disponível em: <http://www.agrioutlook.org/dataoecd/4/35/43037838.pdf>. Acesso em: 23 ago 2010.

OLIVEIRA, Djalma Pinho Rebouças de. Planejamento estratégico: conceitos, metodologia e práticas. 17. ed. São Paulo: Atlas, 2002.

OLIVEIRA, Sílvio Luiz de. Tratado de metodologia científica. São Paulo: Pioneira, 1999.

OLSEN, Svein Ottar et al. Exploring the relationship between convenience and fish consumption: A cross-cultural study. Appetite. v. 49, p.84-91, 2007.

PENA, Bruna Suemy et al. O que devo comer? Influência da cultura no comportamento de consumo de alimentos por gestantes. In: ENCONTRO NACIONAL DE ESTUDOS DO CONSUMO I ENCONTRO LUSO-BRASILEIRO DE ESTUDOS DO CONSUMO TENDÊNCIAS E IDEOLOGIAS DO CONSUMO NO MUNDO CONTEMPORÂNEO ENEC, 5., 2010, Rio de Janeiro. Anais... Rio de Janeiro, 15, 16 e 17 set. 2010.

PÉREZ-CUETO, Federico et al. Food-related lifestyles and their association to obesity in five European countries. Appetite. v. 54, n. 1, p. 156-62, Feb. 2010.

PETIT, J.; VAN DER WERF, Hayo M.G. Perception of the environmental impacts of current and alternative modes of pig production by stakeholder groups. Journal of Environmental Management, v. 68, p.377-386, 2003. 
PINDYCK, Robert S.; RUBINFELD, Daniel L. Microeconomia. São Paulo: Makron Books, 1994.

PINHEIRO, Roberto Meireles; CASTRO, Guilherme Caldas et al. Comportamento do consumidor e pesquisa de mercado. Rio de Janeiro: FGV, 2006.

PORTAL DO AGRONEGÓCIO. 2010. Aprovado projeto que introduz carne suína na merenda escolar da rede pública estadual de ensino no Rio Grande do Sul. Disponível em: <http://www.portaldoagronegocio.com.br/conteudo.php?id=37485>. Acesso em: 11 jan. 2011.

POVEY, Rachel et al. Attitudes towards following meat, vegetarian and vegan diets: an examination of the role of ambivalence. Appetite. v. 1, n. 1, p. 15-26, Aug. 2001.

PORK WORLD. Previsões para a suinocultura 2010. Paulínia, n. 54, v .9, jan./fev. 2010.

REID, M. et al. Food-related lifestyles in a cross-cultural context: comparing Australia with Singapore, Britain, France and Denmark. Journal of Food Products Marketing. v. 7, n. 4, p. 57-75, 2001.

RESANO, Helena et al. Obesity and overall satisfaction with pork meat and derived pork-based products. Nutrición Hospitalaria. Madri, v. 25, n. 1, p. 123-124, ene./feb. 2010.

et al. Consumer satisfaction with pork meat and derived products in five European countries. Appetite. doi:10.1016/j.appet.2010.10.008.

REZENDE, Christiane Leles. A coordenação do sistema agroindustrial do tomate orgânico no estado de São Paulo e o comportamento do consumidor. São Paulo, 2003. Dissertação (Mestrado em Nutrição Humana Aplicada) - Programa de Pós-Graduação Interunidades em Nutrição Humana Aplicada - PRONUT da Universidade de São Paulo.

RICHARDSON, N. et al. Consumer attitudes to meat eating. Meat Science. v. 36, p. 57-65, 1994.

RICHARDSON, R. Pesquisa social: métodos e técnicas. São Paulo: Atlas, 1985.

RICHERS, Raimar. O enigmático mas indispensável consumidor: teoria e prática. Revista de Administração. São Paulo, v. 19, n. 3, p. 46-56, jul./ago./set. 1984.

ROCKEACH, Milton. Beliefs, attitudes, and values. San Francisco: Jossey-Bass, 1968.

. The nature of human values. New York: Free Press, 1973.

ROJO, Francisco. Sumário do estudo sobre o mercado de produtos derivados de suínos. Estrela: Francisco Rojo Consultoria de Marketing, 1994. 13p. (Relatório apresentado à ABCSSINASUI).

ROPPA, Luciano. Suinocultura mundial: situação atual e perspectivas. PorkWorld. Paulínia, v. 4, n. 25, 2005. 
- Carne suína: mitos e verdades. 2006a. Disponível em : <http://porkworld.com.br/artigos/post/carne-suina-mitos-e-verdades>. Acesso em: fev. 2008.

. Coma carne suína no verão. Saúde e Vida on Line. 27/07/2006b. Disponível em: <www.nib.unicamp.br>. Acesso em: 06 out. 2008.

. Brasil: o consumo de carnes passado a limpo. AveWorld. Paulínia, fev./mar. 2008.

. Perspectivas de crescimento do mercado mundial. Palestra proferida na Pork Expo 2010. Curitiba, 24 set. 2010a.

Global meat production to 2019, main meat producers, consumption, exports and imports, developing countries, livestock, trends, meat production, meat consumption, food. Disponível em: <http://www.slideshare.net/Lroppa1947/global-meat-production-liciano-roppa2010>. Acesso em: 18 nov. 2010 b.

ROSENBERG, M. J.; HOVLAND, C. I. Cognitive, affective, and behavioral components of attitudes. In: (Eds.). Attitude organization and change: an analysis of consistency among attitude components. New Haven, CT: Yale University Press, 1960. p. 1-14.

RUDIO, Franz Victor. Introdução ao projeto de pesquisa científica. 13. ed. Petrópolis: Vozes, 1986. $128 \mathrm{p}$.

SAAB, Maria Stella Beregeno Lemos de Melo. Valor percebido pelo consumidor - um estudo de atributos da carne bovina. São Paulo, 1999. Dissertação (Mestrado em Administração) Programa de Pós-Graduação em Administração, Departamento de Administração, Faculdade de Economia, Administração e Contabilidade da Universidade de São Paulo.

et al. Pork value chain in Canada and Brazil: a small comparison. In: INTERNATIONAL PENSA CONFERENCE, 6., 2007, Ribeirão Preto. Proceedings... Ribeirão Preto, out. 2007.

et al. A carne suína no Brasil: um exemplo de coordenação em benefício da cadeia. In: CONGRESSO BRASILEIRO DE CIÊNCIA E TECNOLOGIA DA CARNE, 5., 2009, São Paulo. Anais... São Paulo, 25-27 ago. 2009.

; CLÁUDDIO, Leandro Del Grande. A cadeia produtiva da carne suína no Brasil. Pork World. Paulínia, n. 49, v. 8, mar./abr. 2009.

; NEVES, Marcos Fava. Pork chain in Brazil and Canada: a comparison. In: TRIENEKENS, Jacques; WOGNUN, Nel (Orgs.). European pork chains - diversity and quality challenges in consumer-oriented production and distribution. Wageningen, The Netherlands: Wageningen Academic Publishers, 2009. p. 245-255.

et al. Pork consumption in Brazil. In: Q-PORKCHAINS PUBLIC CONFERENCE, University of Bonn/GIQS, Bonn, Alemanha, 18 Nov. 2009. 
SANT’ANNA, Armando. Propaganda: teoria, técnica e prática. São Paulo: Atlas, 1989.

SCHIFFMAN, Leon G.; KANUK, Leslie Lazar. Comportamento do consumidor. 6. ed. Rio de Janeiro: LTC, 2000.

SCHLINDWEIN, Madalena Maria; KASSOUF, Ana Lúcia. Análise da influência de alguns fatores socioeconômicos e demográficos no consumo domiciliar de carnes no Brasil. Revista de Economia e Sociologia Rural. Rio de Janeiro, v. 44, n. 3, p. 549-572, jul./ago./set. 2006.

SCHOLDERER, Joachim et al. Cross-cultural validity of the food-related lifestyles instrument (FRL) within Western Europe. Appetite. v. 42, n. 2, p. 197-211, 2004.

. The relative importance of habitual and deliberative factors in food consumer behaviour. Appetite. v. 47, n. 2, p. 276, Sept. 2006.

Measurement invariance of the Portrait Values Questionnaire across 25 European countries. In: CROSS-CULTURAL RESEARCH CONFERENCE, 12., 2007, Honolulu. Proceedings...Honolulu, HI, 12-15 Dec. 2007.

. Product-person-environment fit: an interactionist approach to market segmentation. Manuscrito submetido para publicação, 2009.

SCHWARTZ, Shalom H. Universals in the content and structure of values: Theory and empirical tests in 20 countries. In: ZANNA, M. (Ed.). Advances in experimental social psychology. New York: Academic Press, v. 25, p. 1-65, 1992.

- Basic human values: an overview. Disponível em: <http://segrdid2.fmag.unict.it/Allegati/convegno\%207-8-10-05/Schwartzpaper.pdf>. Acesso em: jun. 2009.

SCHWARTZ, Shalom H.; BILSKY, W. Towards a universal psychological structure of human values. Journal of Personality and Social Psychology,.v. 53, p. 550-562, 1987.

SCOT CONSULTORIA. Diversas comunicações e consultas verbais feitas ao longo dos anos de 2008, 2009 e 2010.

SERAGINI, Lincoln; CARVALHO, E. G. Identidade de produto: design original e prestígio de marca. In: CARVALHO, Dirceu Tornavoi; NEVES, Marcos Fava (Coord.). Marketing na nova economia. São Paulo: Atlas, 2001. p. 127-137.

SERRALVO, Francisco Antônio; IGNACIO, Cláudia Pereira. O comportamento do consumidor de produtos alimentícios: um estudo exploratório sobre a importância das marcas líderes. In: SEMINÁRIOS EM ADMINISTRAÇÃO - SEMEAD, 7., 2004, São Paulo. Anais... São Paulo: FEA/USP, 2004.

SHAPIRO, Mathew D. Capital utilization and capital accumulation: theory and evidence. Journal of Applied Econometrics. v. 1, n. 3, p. 211-34, July 1986. 
SHELMAN, Mary Louise. The agribusiness systems approach - cases and concepts. In: INTERNATIONAL AGRIBUSINESS MANAGEMENT ASSOCIATION CONFERENCE IAMA. Proceedings... Mar. 3-5 1991.

SHEPHERD, R. Attitudes and beliefs as determinants of food choice. In: McBRIDE, R. L.; MacFIE, H. J. H. (Eds.). Psychological basis of sensory evaluation. London: Elsevier Applied Science, 1990. p. 141-158.

SHETH, Jagdish N. et al. Comportamento do cliente: indo além do comportamento do consumidor. São Paulo: Atlas, 2001. 795 p.

et al. Marketing theory: evolution and evaluation. New York: Wiley, 1988. 231 p.

et al. Why we buy what we buy: a theory of consumption values. Journal of Business Research, New York, v. 22, n. 2, p. 159-170, 1991.

SHIMP, Terence A.; SHARMA, Subhash. Consumer ethnocentrism: construction and validation of the CETSCALE. Journal of Market Research. v. 24, p. 280-289, Aug1987

SICHIERI, Rosely et al. Rationale, design, and analysis of combined Brazilian household budget survey and food intake individual data. BMC Public Health. 2008, 8:89 Disponível em: <http://www.biomedcentral.com/1471-2458/8/89>. Acesso em: 3 mar. 2010.

SILVA, Jobson Paulo; SILVA, Ludmila da Paz Gomes da. Avaliação e comportamento do consumidor de carne suína na microrregião de Guarabira-PB. 21 jan. 2009. Disponível em $<$ http://www.artigonal.com/print/732770>. Acesso em: 28 maio 2010.

SILVA, Roberto Aguilar Machado Santos. Por que estudar o comportamento do consumidor de carnes? Informativo da cadeia da carne bovina do Pantanal Mato-Grossense. Ano I. n ${ }^{0} .004$. Corumbá: Embrapa / Ministério da Agricultura, Pecuária e Abastecimento. 25 fev. 2009.

SILVEIRA, Paulo Roberto Souza da; TALAMINI, Dirceu João Duarte. A cadeia produtiva de suínos no Brasil. Revista CFMV-Conselho Federal de Medicina Veterinária, Brasília/DF, Ano 13, v. 42, p. 11-20, 2007.

SORENSEN, Bjarne Taulo. A short review of research on consumer perception of pork (meat) quality. 2007. Documento interno do Projeto Integrado Q-PorkChains.

; SCHOLDERER, Joachim. Systems of attitudes towards production systems in the pork industry. Manuscrito submetido para publicação, 2009.

SOLOMON, Michael. O comportamento do consumidor: comprando, possuindo e sendo. 5. ed. Porto Alegre: Bookman, 2002. 446 p.

SPERS, Eduardo Eugênio. Avaliação da preferência do consumidor por atributos de segurança no morango através da conjoint analysis. Piracicaba, 1998. Dissertação (Mestrado em Economia Aplicada) - Escola Superior de Agronomia Luiz de Queiroz da Universidade de São Paulo - ESALQ-USP. 
SPERS, Eduardo E.; ROCHA, Patricia M.; SPERS, Valéria R. Consumer perception about organic food in Brazil. In: INTERNATIONAL PENSA CONFERENCE, 6, 2007, Ribeirão

Preto. Anais... Ribeirão Preto: PENSA, out. 2007.

. Mecanismos de regulação da qualidade e segurança em alimentos. São Paulo, 2003. Tese (Doutorado em Administração) - Programa de Pós Graduação em Administração, Departamento de Administração, Faculdade de Economia, Administração e Contabilidade da Universidade de São Paulo.

SOUKI, Gustavo Quiroga. Estratégias de marketing para os agentes da cadeia da carne bovina. Lavras, 2003. Tese (Doutorado em Administração) - Universidade Federal de Lavras.

STANTON, William J. Fundamentals of marketing. 3rd. ed. New York: International Student Edition, Mc Graw-Hill Book Company, 1971.

STEENKAMP, Jan-Benedict. Food consumption behavior. European Advances in Consumer Research. v. 1, 1993.

; BAUMGARTNER, H. Assessing measurement invariance in cross-nacional consumer research. Journal of Consumer Research. v. 25, p. 78-90, Jun 1998.

STEPTOE, A. et al. Development of the motives underlying the selection of food: the food choice questionnaire. Appetite. v. 25, p. 267-284, 1995.

STURGEON, Timothy J. How we define value chains and production networks? MIT IPC Working Paper 00-010. Industrial Performance Center, Massachusetts Institute of Technology, 2000 .

TIBOLA, Fernando et al. Atributos importantes da compra de notebooks: um estudo exploratório. SEMINÁRIOS EM ADMINISTRAÇÃO - SEMEAD, 7., 2004, São Paulo. Anais... São Paulo: FEA/USP., 2004. Disponível em: <http://www.ead.fea.usp.br/Semead/7Semead/marketing/MKT10_Atributos_compra_Notebook. PDF>. Acesso em: 14 ago. 2010.

TRICHOPOlOU, A. et al. Disparities in food habits across Europe. The Proceedings of the Nutrition Society. v. 61, n. 4, p.553-8, 2002.

TRIENEKENS, Jacques; WOGNUN, Nel. Introduction to the European pork chain. In: et al. European pork chains - diversity and quality challenges in consumer-oriented production and distribution. Wageningen, The Netherlands: Wageningen Academic Publishers, 2009. p. 1936.

TRUOCCHIO, Tânia Batista Ribeiro; ANTONIALLI, Luiz Marcelo. Atributos considerados importantes na decisão de compra dos compradores de carne suína em Belo Horizonte-MG. In: CONGRESSO DA SOBER - SOCIEDADE BRASILEIRA DE ECONOMIA, ADMINISTRAÇÃO E SOCIOLOGIA RURAL.2008, Rio Branco. Anais... Acre, 20-23 jul. 2008. 
TYBOUT, Alice M.; CARPENTER, Gregory S. Criação e gestão de marcas. In: IACOBUCCI, Dawn (Org.). Os desafios do marketing. São Paulo: Futura, 2001.

UNIVERSITY OF THE WEST OF ENGLAND. Data analysis on-line learning programme, 2007. Disponível em: 〈http://hsc.uwe.ac.uk/dataanalysis/quantInfAssPear.asp>. Acesso em: 14 out. 2010.

URALA, N.; LAHTEENMAKI, Liisa. Reasons behind consumers' functional food choices. Nutrition and Food Science. v. 33, p. 148-158, 2003.

USDA - United States Department of Agriculture. Foreign Agricultural Service. World markets and trade. Disponível em: <http://www.fas.usda.gov/dlp/circular/2007/livestockpoultry042007.pdf>. Acesso em: 20/06/2008.

VANHONACKER, F. et al. Do citizens and farmers interpret the concept of farm animal welfare differently? Livestock Science. v. 116, p. 126-136, 2008.

. Societal concern related to stocking density, pen size and group size in farm animal production. Livestock Science. v. 123, p.16-22, 2009.

VENDRAME, Francisco Cesar et al. O comportamento do consumidor de carne bovina. In: CONGRESSO DE PÓS GRADUAÇÃO, 6., 2008, Anais... Piracicaba: Unimep, set./out. 2008.

VERBEKE, Wim. Consumer acceptance of functional foods: socio-demographic, cognitive and attitudinal determinants. Food Quality and Preference. v. 16, p. 45-57, 2005.

. Functional foods: Consumer willingness to compromise on taste for health? Food Quality and Preference. v. 17, p. 126-131, 2006.

; VACKIER, Isabelle. Profile and effects of consumer involvement in fresh meat. Meat Science. v. 67, p. 159-168, 2004.

; I Individual determinants of fish consumption: application of the theory of planned behavior. Appetite. v. 44, p. 67-82, 2005.

et al. Q-Pork Chains: Improving the quality of pork and pork products for the consumer: Development of innovative, integrated, and sustainable food production chains of high quality pork products matching consumer demands. Deliverable D.1.1.2 Pork consumption in Europe and beyond: comprehensive report. Part A: Pork consumption in Europe. Documento interno, 2008.

Q-Pork Chains: Improving the quality of pork and pork products for the consumer: Development of innovative, integrated, and sustainable food production chains of high quality pork products matching consumer demands. Deliverable D-I.1.3. Segmentation study: citizens and consumers. Documento interno, 2009.

et al. European citizen and consumer attitudes and preferences regarding beef and pork.

Meat Science. v. 84, p. 284-292, 2010. 
VIEIRA, Adriana Carvalho Pinto. Instituição e segurança dos alimentos: construindo uma nova institucionalidade. Campinas, 2009. Tese (Doutorado em Desenvolvimento Econômico) Instituto de Economia. Programa de Pós-Graduação em Desenvolvimento Econômico, Universidade Estadual de Campinas (Unicamp).

WEYDMANN, Celso Leonardo. O padrão concorrencial na agroindústria suína e as estratégias ambientais. In: GUIVANT, Julia Silvia; MIRANDA, Cláudio da Rocha (Org.) Desafios para o desenvolvimento sustentável da suinocultura. Chapecó: Argos/Embrapa, 2004. v. 1, p. 173199.

WHITLEY, Richard. Business systems and global commodity chains: competing or complementary forms of economic organisations? Competition and change. v. 1, n. 4. p. 411425, 1996.

ZAMBERLAN, Luciano et al. As atitudes do consumidor de carne: um estudo exploratório das percepções e o papel da cultura no consumo. In: ENCONTRO NACIONAL DA ASSOCIAÇÃO NACIONAL DE PÓS-GRADUAÇÃO EM ADMINISTRAÇÃO - ENANPAD, 32., 2008, Rio de Janeiro. Anais... Rio de Janeiro: ANPAD, 6-16 set. 2008.

et al. Do churrasco à parrilha: um estudo sobre a influência da cultura nos rituais alimentares de brasileiros e argentinos. In: ENCONTRO NACIONAL DOS PROGRAMAS DE PÓS-GRADUAÇÃO EM ADMINISTRAÇÃO - ENANPAD, 33., 2009, Rio de Janeiro. Anais... Rio de Janeiro: ANPAD, 2009.

ZEITHAML, Valarie A. Consumer perceptions of price, quality, and value: a means-end model and systhesis of evidence. Journal of Marketing. v. 52, n. 3, p. 2-22, July 1988.

ZYLBERSZTAJN, Decio. Estruturas de governança e coordenação do agribusiness: uma aplicação da nova economia das instituições. São Paulo, 1995. Tese (Livre-Docência) Departamento de Administração, Faculdade de Economia, Administração e Contabilidade da Universidade de São Paulo.

. Palestra apresentada no Seminário Nacional de Desenvolvimento da Suinocultura. Foz do Iguaçu, jul. 2009.

Fragile Social Norms: (Un) Sustainable Exploration of Forest Products. International

Journal on Food System Dynamics. North America, 1, Jan. 2010. Disponível em: <http://131.220.45.179/ojs/index.php/fsd/article/view/10/9>. Acesso em: 24 abr. 2010.

et al. Estudos de caso em agribusiness. Porto Alegre: Ortiz, 1993.

; NEVES, Marcos Fava (Org.). Economia e gestão dos negócios agroalimentares. São Paulo: Pioneira, 2000.

; FARINA, Elizabeth Maria Mercier Querido. Agri-system management: recent developments and applicability of the concept. PENSA/FEA/USP. In: BRAZILIAN WORKSHOP ON AGRI-CHAIN MANAGEMENT, 1., 1997, Ribeirão Preto. Proceedings... Ribeirão Preto, 10-11 nov. 1997. 


\section{APÊNDICES}

\section{APÊNDICE A -- QUESTIONÁRIO}

$\begin{array}{lc}\text { Nome } & \text { Telefone } \\ \text { Endereço } & \text { Bairro: } \\ \text { Nome do Entrevistador } & \text { Criticado por: }\end{array}$

Prezado,

Neste momento estamos realizando uma grande pesquisa internacional para diferentes universidades da Europa. Este estudo, que faz parte de um projeto de pesquisa patrocinado por fundos públicos, procura entender melhor as atitudes dos consumidores com relação a produtos alimentares e à produção de alimentos.

Este questionário levará cerca de $\mathbf{5 0}$ minutos para ser respondido.

Sua participação neste estudo é muito importante.

Gostaríamos de lembrar que o anonimato de suas respostas é garantido, pois elas serão analisadas como um todo e nunca de forma personalizada.

\section{PARTE 1 - SÓCIODEMOGRÁFICA}

\section{SDO. Marque a cidade correspondente:}

\begin{tabular}{|l|l|}
\hline 1. & Porto Alegre \\
\hline 2. & Santa Rosa \\
\hline 3. & Curitiba \\
\hline 4. & Ponta Grossa \\
\hline
\end{tabular}

\begin{tabular}{|c|l|}
\hline 5. & Cuiabá \\
\hline 6. & Campo Verde \\
\hline 7. & Goiânia \\
\hline 8. & Rio Verde \\
\hline
\end{tabular}

SD1. (sexo)

\begin{tabular}{|l|l|l|l|}
\hline 1. & Feminino & 2. & Masculino \\
\hline
\end{tabular}

SD2. Em que ano você nasceu? (POR FAVOR, COLOQUE O ANO CERTO) 19 I____ I I__ I

SD3. Que opção descreve melhor seu estado civil? (RU)

\begin{tabular}{|c|l|}
\hline 1. & Casado \\
\hline 2. & Não casado, mas morando junto \\
\hline 3. & Solteiro(a), vivendo sozinho \\
\hline 4. & Divorciado \\
\hline 5. & Viúvo \\
\hline
\end{tabular}

\section{SD4. Qual é sua formação completa? (APENAS UMA RESPOSTA)}

\begin{tabular}{|c|l|}
\hline 1. & Ensino fundamental incompleto \\
\hline 2. & Ensino fundamental completo \\
\hline 3. & Ensino médio completo \\
\hline 4. & Faculdade e/ou Pós \\
\hline
\end{tabular}


SD6. Qual é sua ocupação atual? (RU)

\begin{tabular}{|c|l|}
\hline 1. & Produtor rural autônomo ou integrado \\
\hline 2. & Autônomo \\
\hline 3. & Supervisor \\
\hline 4. & Trabalhador assalariado \\
\hline 5. & Trabalhador qualificado \\
\hline 6. & Trabalhador não qualificado \\
\hline 7. & Estudante \\
\hline 8. & Aposentado \\
\hline 9. & Desempregado ou em transição \\
\hline 10. & Não trabalha \\
\hline 49 & Outros (ESPECIFIQUE) \\
\hline
\end{tabular}

SD8. Qual o seu peso (em quilos)? (COLOQUE O NÚMERO EXATO)

$\mid K G$

SD9. Qual sua altura (em centímetros)? POR EXEMPLO: SE 1 METRO E 70, ANOTE 170

Centímetro

SD10. Entrevistador, registre o tipo de local onde o entrevistado mora (RU)

\begin{tabular}{|c|l|}
\hline 1. & Em uma cidade grande \\
\hline 2. & No subúrbio ou nos arredores de uma cidade grande \\
\hline 3. & Em um município ou cidade pequena \\
\hline 4. & Em uma vila do interior \\
\hline 5. & Em uma fazenda ou casa no campo \\
\hline 6. & Não sabe \\
\hline
\end{tabular}

SD11. Quantas pessoas moram em sua casa, em cada uma das faixas etárias, incluindo você?

ANOTE O № DE PESSOAS, INCLUINDO ENTREVISTADO(A)

\begin{tabular}{|c|c|}
\hline 1. & 0 (NÃO PODE) \\
\hline 2. & 1 \\
\hline 3. & 2 \\
\hline 4. & 3 \\
\hline 5. & 4 ou mais \\
\hline
\end{tabular}

VEJA O № DE PESSOAS E CIRCULE EM QUAIS IDADES ELAS ESTÃO, INCLUINDO ENTREVISTADO

\begin{tabular}{|l|l|c|l|}
\hline 1. & $0-2$ anos & 7. & $22-25$ anos \\
\hline 2. & $3-5$ anos & 8. & $26-29$ anos \\
\hline 3. & $6-9$ anos & 9. & $30-39$ anos \\
\hline 4. & $10-13$ anos & 10. & $40-49$ anos \\
\hline 5. & $14-17$ anos & 11. & $50-59$ anos \\
\hline 6. & $18-21$ anos & 12. & 60 anos ou mais \\
\hline
\end{tabular}

SEC. Quais e quantos dos itens que vou ler você possui em seu domicílio?

\begin{tabular}{|l|c|c|c|c|c|c|c|}
\hline & Não tem & $\mathbf{1}$ & $\mathbf{2}$ & $\mathbf{3}$ & $\mathbf{4}$ ou + & Nível de instrução do chefe da familia & \\
\hline TV colorida & 0 & 1 & 2 & 3 & 4 & Analfabeto / Até $3^{\text {a }}$ série & 0 \\
\hline Videocassette (VCRs) ou DVD & 0 & 2 & 2 & 2 & 2 & Primário completo / $4^{\mathrm{a}}$ série & 1 \\
\hline
\end{tabular}




\begin{tabular}{|l|l|l|l|l|l|l|l|}
\hline Rádio & 0 & 1 & 2 & 3 & 4 & Ensino Fundamental / Ginásio completo & 2 \\
\hline Banheiro & 0 & 4 & 5 & 6 & 7 & Ensino médio / Colegial completo & 4 \\
\hline Carro & 0 & 4 & 7 & 9 & 9 & Superior completo & 8 \\
\hline Empregada doméstica & 0 & 3 & 4 & 4 & 4 & Pós-graduação / Doutorado / Mestrado & 8 \\
\hline Máquina de lavar & 0 & 2 & 2 & 2 & 2 & \\
\hline Refrigerador & 0 & 4 & 4 & 4 & 4 & \\
\hline Freezer & 0 & 2 & 2 & 2 & 2 \\
\hline
\end{tabular}

Critério de classificação:

\begin{tabular}{|c|c|c|}
\hline A1 & $42-46$ pontos & 1 \\
\hline A2 & $35-41$ pontos & 2 \\
\hline B1 & $29-34$ pontos & 3 \\
\hline B2 & $23-28$ pontos & 4 \\
\hline C1 & $18-22$ pontos & 5 \\
\hline C2 & $14-99$ pontos & 6 \\
\hline D/E & $0-13$ pontos & AGRADEÇA E ENCERRE \\
\hline
\end{tabular}

\section{PARTE 2 - QUESTÕES RELACIONADAS AO ESTILO DE VIDA}

Q1. Vou ler algumas frases e gostaria de saber o quanto concorda com cada uma delas.

Você pode responder com um número de 1 a 7 , onde 1 significa "discordo totalmente" e 7 significa "concordo totalmente". Você também pode responder com os números intermediários, entre o 1 e o 7 .

\section{$\mathbf{1 =}$ discordo totalmente $\quad \mathbf{4}=$ Não concordo nem discordo $\quad \mathbf{7 =}$ concordo totalmente}

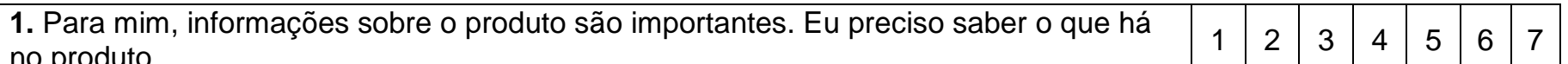
no produto.

2.ENTREVISTADOR, PERGUNTAR APENAS PARA QUEM NÃO MORA SOZINHO:

As crianças e outros familiares sempre ajudam na cozinha; por exemplo, descascam batatas e cortam os vegetais.

3. Eu só compro e consumo alimentos que conheço bem.

4. Não tenho interesse em comprar comida.

5. Acho importante o sabor dos alimentos.

6. Normalmente não decido o que comprar antes de chegar ao mercado.

7. Acho importante saber que tenho qualidade pelo que pago.

8. Receitas bem conhecidas são as melhores.

9. Faço questão de usar alimentos naturais ou ecológicos.

10. Eu como antes de sentir fome, o que significa que nunca tenho fome nas horas das refeições.

11. Eu comparo as informações entre produtos para escolher qual marca comprar.

12. Gosto de comprar alimentos em lojas especializadas onde posso ter dicas de especialistas.

13. Eu comparo preços entre produtos parecidos para valorizar o dinheiro.

14. Consumimos muita comida comprada pronta em nossa casa.

\begin{tabular}{l|l|l|l|l|l|l}
1 & 2 & 3 & 4 & 5 & 6 & 7
\end{tabular}

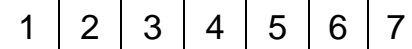

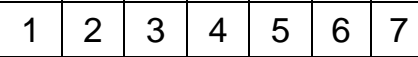

\begin{tabular}{lllllllll}
1 & 2 & 3 & 4 & 5 & 6 & 7 \\
\hline
\end{tabular}

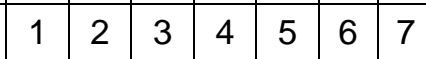

\begin{tabular}{l|l|l|l|l|l|l|}
1 & 2 & 3 & 4 & 5 & 6 & 7 \\
\hline 1 & 2 & 3 & 4 & 5 & 6 & 7
\end{tabular}

\begin{tabular}{l|l|l|l|l|l|l|}
1 & 2 & 3 & 4 & 5 & 6 & 7 \\
\hline 1 & 2 & 3 & 4 & 5 & 6 & 7 \\
\hline
\end{tabular}

\begin{tabular}{|l|l|l|l|l|l|l|}
1 & 2 & 3 & 4 & 5 & 6 & 7 \\
\hline
\end{tabular}

\begin{tabular}{l|l|l|l|l|l|l|}
1 & 2 & 3 & 4 & 5 & 6 & 7 \\
\hline
\end{tabular}

\begin{tabular}{l|l|l|l|l|l|l|}
1 & 2 & 3 & 4 & 5 & 6 & 7
\end{tabular}

\begin{tabular}{|l|l|l|l|l|l|l|}
1 & 2 & 3 & 4 & 5 & 6 & 7 \\
\hline 1 & 2 & 3 & 4 & 5 & 6 & 7 \\
\hline
\end{tabular}




\begin{tabular}{|c|c|c|c|c|c|c|c|}
\hline 15. Eu percebo quando os produtos que compro mudam de preço. & 1 & 2 & 3 & 4 & 5 & 6 & 7 \\
\hline 16. Eu compro produtos orgânicos sempre que tenho oportunidade. & 1 & 2 & 3 & 4 & 5 & 6 & 7 \\
\hline 17. Jantar com amigos é uma parte importante de minha vida social. & 1 & 2 & 3 & 4 & 5 & 6 & 7 \\
\hline 18. Não gosto de passar muito tempo cozinhando. & 1 & 2 & 3 & 4 & 5 & 6 & 7 \\
\hline 19. Eu não gosto de nada que possa mudar meus hábitos alimentares. & 1 & 2 & 3 & 4 & 5 & 6 & 7 \\
\hline $\begin{array}{l}\text { 20. Eu confio mais em produtos dos quais já vi propagandas do que naqueles que não } \\
\text { têm propaganda. }\end{array}$ & 1 & 2 & 3 & 4 & 5 & 6 & 7 \\
\hline 21. Quando cozinho, considero o sabor em primeiro lugar. & 1 & 2 & 3 & 4 & 5 & 6 & 7 \\
\hline 22. Prefiro produtos frescos a enlatados ou congelados. & 1 & 2 & 3 & 4 & 5 & 6 & 7 \\
\hline $\begin{array}{l}\text { 23. Em nossa casa, temos o costume de "beliscar", o que substituiu os horários das } \\
\text { refeições. }\end{array}$ & 1 & 2 & 3 & 4 & 5 & 6 & 7 \\
\hline 24. Procuro formas de preparar refeições diferenciadas. & 1 & 2 & 3 & 4 & 5 & 6 & 7 \\
\hline 25. Não vejo motivos para comprar em lojas especializadas. & 1 & 2 & 3 & 4 & 5 & 6 & 7 \\
\hline $\begin{array}{l}\text { 26. É responsabilidade da mulher manter a família saudável, servindo uma dieta } \\
\text { nutritiva. }\end{array}$ & 1 & 2 & 3 & 4 & 5 & 6 & 7 \\
\hline 27. Sair para jantar faz parte de nossos hábitos alimentares. & 1 & 2 & 3 & 4 & 5 & 6 & 7 \\
\hline $\begin{array}{l}\text { 28. Procuro anúncios nos jornais de promoções em lojas e planejo aproveitá-las } \\
\text { quando vou fazer compras. }\end{array}$ & 1 & 2 & 3 & 4 & 5 & 6 & 7 \\
\hline 29. Eu comparo etiquetas para escolher o alimento mais nutritivo. & 1 & 2 & 3 & 4 & 5 & 6 & 7 \\
\hline 30. Não me importo em pagar mais por produtos ecológicos. & 1 & 2 & 3 & 4 & 5 & 6 & 7 \\
\hline 31.Eu sempre planejo o que vamos comer com alguns dias de antecedência. & 1 & 2 & 3 & 4 & 5 & 6 & 7 \\
\hline $\begin{array}{l}\text { 32. Hoje em dia a responsabilidade de fazer compras e cozinhar é tanto do marido } \\
\text { quanto da esposa. }\end{array}$ & 1 & 2 & 3 & 4 & 5 & 6 & 7 \\
\hline 33. Uma refeição em família me dá sensação de segurança. & 1 & 2 & 3 & 4 & 5 & 6 & 7 \\
\hline $\begin{array}{l}\text { 34.ENTREVSITADOR, PERGUNTAR APENAS PARA QUEM NÃO MORA SOZINHO } \\
\text { Minha família me ajuda com outras tarefas ligadas à refeição, como arrumar a mesa e } \\
\text { lavar louça. }\end{array}$ & 1 & 2 & 3 & 4 & 5 & 6 & 7 \\
\hline 35. Considero uma qualidade a comida que compro ser natural. & 1 & 2 & 3 & 4 & 5 & 6 & 7 \\
\hline $\begin{array}{l}\text { 36. Gosto de saber o que compro, então sempre faço perguntas nas lojas onde compro } \\
\text { comida. }\end{array}$ & 1 & 2 & 3 & 4 & 5 & 6 & 7 \\
\hline $\begin{array}{l}\text { 37. Receitas e artigos de alimentação de outras tradições culinárias me fazem } \\
\text { experimentar mais na cozinha. }\end{array}$ & 1 & 2 & 3 & 4 & 5 & 6 & 7 \\
\hline 38. É possível ter uma conversa agradável durante uma refeição. & 1 & 2 & 3 & 4 & 5 & 6 & 7 \\
\hline 39. Acho importante os alimentos serem frescos. & 1 & 2 & 3 & 4 & 5 & 6 & 7 \\
\hline 40. Adoro experimentar receitas de países estrangeiros. & 1 & 2 & 3 & 4 & 5 & 6 & 7 \\
\hline 41. Sempre vejo o preço, mesmo de itens pequenos. & 1 & 2 & 3 & 4 & 5 & 6 & 7 \\
\hline 42. Gosto de ir a restaurantes com minha família e amigos. & 1 & 2 & 3 & 4 & 5 & 6 & 7 \\
\hline 43. Gosto de ter bastante tempo na cozinha. & 1 & 2 & 3 & 4 & 5 & 6 & 7 \\
\hline 44. Sou influenciado pelo que as pessoas dizem sobre um alimento. & 1 & 2 & 3 & 4 & 5 & 6 & 7 \\
\hline 45. Sempre nos juntamos com amigos para uma refeição casual, fácil de preparar. & 1 & 2 & 3 & 4 & 5 & 6 & 7 \\
\hline 46. Comprar comida é como um jogo para mim. & 1 & 2 & 3 & 4 & 5 & 6 & 7 \\
\hline 47. Antes de ir fazer compras, faço uma lista com tudo o que preciso. & 1 & 2 & 3 & 4 & 5 & 6 & 7 \\
\hline 48. Prefiro comprar carnes e vegetais frescos a pré-embalados. & 1 & 2 & 3 & 4 & 5 & 6 & 7 \\
\hline 49.Tento evitar alimentos com aditivos. & 1 & 2 & 3 & 4 & 5 & 6 & 7 \\
\hline
\end{tabular}




\begin{tabular}{|c|c|c|c|c|c|c|c|}
\hline 50. É mais importante escolher produtos pelo valor nutricional do que pelo sabor. & 1 & 2 & 3 & 4 & 5 & 6 & 7 \\
\hline 51. Ser elogiado pela minha comida aumenta muito minha autoestima. & 1 & 2 & 3 & 4 & 5 & 6 & 7 \\
\hline 52. Comida congelada é muito consumida em nossa casa. & 1 & 2 & 3 & 4 & 5 & 6 & 7 \\
\hline 53. Eu adoro comprar comida. & 1 & 2 & 3 & 4 & 5 & 6 & 7 \\
\hline 54. Sou um excelente cozinheiro. & 1 & 2 & 3 & 4 & 5 & 6 & 7 \\
\hline 55. Quando sirvo uma refeição a meus amigos, o mais importante é estarmos juntos. & 1 & 2 & 3 & 4 & 5 & 6 & 7 \\
\hline 56. Prefiro comprar produtos naturais, isto é, sem conservantes. & 1 & 2 & 3 & 4 & 5 & 6 & 7 \\
\hline 57. Considero a cozinha um domínio das mulheres. & 1 & 2 & 3 & 4 & 5 & 6 & 7 \\
\hline 58. Informações dos anúncios me ajudam a decidir melhor sobre minha compra. & 1 & 2 & 3 & 4 & 5 & 6 & 7 \\
\hline 59. Uso muitas misturas, como misturas para bolos e sopas em pó. & 1 & 2 & 3 & 4 & 5 & 6 & 7 \\
\hline 60. Faço uma lista de compras para guiar minhas compras. & 1 & 2 & 3 & 4 & 5 & 6 & 7 \\
\hline 61. O que vamos comer em uma refeição costuma ser uma decisão de última hora. & 1 & 2 & 3 & 4 & 5 & 6 & 7 \\
\hline 62. Cozinhar é uma tarefa que é melhor ser feita depressa. & 1 & 2 & 3 & 4 & 5 & 6 & 7 \\
\hline $\begin{array}{l}\text { 63. Para mim, comer é uma questão de tocar, sentir o cheiro, provar e ver, todos os } \\
\text { sentidos são envolvidos. É uma sensação muito estimulante. }\end{array}$ & 1 & 2 & 3 & 4 & 5 & 6 & 7 \\
\hline 64. Eu sempre tento conseguir boa qualidade com o melhor preço. & 1 & 2 & 3 & 4 & 5 & 6 & 7 \\
\hline 65. Eu como sempre que sinto um pouco de fome. & 1 & 2 & 3 & 4 & 5 & 6 & 7 \\
\hline 66. Cozinhar precisa ser planejado com antecedência. & 1 & 2 & 3 & 4 & 5 & 6 & 7 \\
\hline 67. Gosto de experimentar alimentos que nunca experimentei. & 1 & 2 & 3 & 4 & 5 & 6 & 7 \\
\hline $\begin{array}{l}\text { 68. ENTREVISTADOR, PERGUNTAR APENAS PARA QUEM NÃO MORA SOZINHO: } \\
\text { Quando não tenho vontade de cozinhar, peço para outros membros de minha família } \\
\text { fazerem isso. }\end{array}$ & 1 & 2 & 3 & 4 & 5 & 6 & 7 \\
\hline 69.Gosto de tentar receitas novas. & 1 & 2 & 3 & 4 & 5 & 6 & 7 \\
\hline
\end{tabular}

\section{VALORES ILUSTRADOS DE SCHWARTZ}

Q2. Vou ler algumas descrições e gostaria de saber o quanto essa pessoa se parece com você. Você pode responder com um número entre 1 e 6, em que 1 significa "Não tem nada a ver comigo" e 6 significa "Exatamente como eu". Ou os intermediários.

\section{SÓ PARA HOMENS RODIZIAR}

\begin{tabular}{|c|c|c|c|c|c|c|c|}
\hline & & comigo & comigo & comigo & - & & $\mathrm{eu}$ \\
\hline A & $\begin{array}{l}\text { Um homem que dá importância a ter novas ideias e ser criativo. } \\
\text { Gosta de fazer as coisas à sua maneira. }\end{array}$ & 1 & 2 & 3 & 4 & 5 & 6 \\
\hline B & $\begin{array}{l}\text { Um homem para quem é importante ser rico. Quer ter muito } \\
\text { dinheiro e coisas caras. }\end{array}$ & 1 & 2 & 3 & 4 & 5 & 6 \\
\hline C & $\begin{array}{l}\text { Um homem que acha importante que todas as pessoas no } \\
\text { mundo sejam tratadas igualmente. Acredita que todos devem ter } \\
\text { as mesmas oportunidades na vida. }\end{array}$ & 1 & 2 & 3 & 4 & 5 & 6 \\
\hline D & $\begin{array}{l}\text { Um homem que dá muita importância a poder mostrar suas } \\
\text { capacidades. Quer que as pessoas admirem o que faz. }\end{array}$ & 1 & 2 & 3 & 4 & 5 & 6 \\
\hline E & $\begin{array}{l}\text { Um homem que dá importância a viver num sítio onde se sinta } \\
\text { seguro. Evita tudo o que possa pôr sua segurança em risco. }\end{array}$ & 1 & 2 & 3 & 4 & 5 & 6 \\
\hline
\end{tabular}




\begin{tabular}{|c|c|c|c|c|c|c|c|}
\hline & $\begin{array}{l}\text { SÓ PARA HOMENS } \\
\text { RODIZIAR }\end{array}$ & $\begin{array}{c}\text { Não tem } \\
\text { nada a } \\
\text { ver } \\
\text { comigo }\end{array}$ & $\begin{array}{c}\text { Muito } \\
\text { pouco } \\
\text { parecido } \\
\text { comigo }\end{array}$ & $\begin{array}{c}\text { Um } \\
\text { pouco } \\
\text { parecido } \\
\text { comigo }\end{array}$ & $\begin{array}{l}\text { Pare } \\
\text { cido } \\
\text { comigo }\end{array}$ & $\begin{array}{l}\text { Muito } \\
\text { parecido } \\
\text { comigo }\end{array}$ & $\begin{array}{c}\text { Exata- } \\
\text { mente } \\
\text { como } \\
\text { eu }\end{array}$ \\
\hline $\mathbf{F}$ & $\begin{array}{l}\text { Um homem que gosta de surpresas e está sempre à procura de } \\
\text { coisas novas para fazer. Acha que é importante fazer muitas } \\
\text { coisas diferentes na vida. }\end{array}$ & 1 & 2 & 3 & 4 & 5 & 6 \\
\hline $\mathbf{G}$ & $\begin{array}{l}\text { Um homem que acha que as pessoas devem fazer o que lhes } \\
\text { mandam. Acha que as pessoas devem cumprir sempre as } \\
\text { regras mesmo quando ninguém está vendo. }\end{array}$ & 1 & 2 & 3 & 4 & 5 & 6 \\
\hline H & $\begin{array}{l}\text { Um homem para quem é importante ouvir pessoas diferentes. } \\
\text { Mesmo quando discorda de alguém, continua querendo } \\
\text { compreender essa pessoa. }\end{array}$ & 1 & 2 & 3 & 4 & 5 & 6 \\
\hline I & $\begin{array}{l}\text { Um homem para quem é importante ser humilde e modesto. } \\
\text { Tenta não chamar as atenções para si. }\end{array}$ & 1 & 2 & 3 & 4 & 5 & 6 \\
\hline $\mathbf{J}$ & $\begin{array}{l}\text { Um homem para quem é importante passar bons momentos. } \\
\text { Gosta de tratar bem de si mesmo. }\end{array}$ & 1 & 2 & 3 & 4 & 5 & 6 \\
\hline $\mathrm{K}$ & $\begin{array}{l}\text { Um homem para quem é importante tomar as próprias decisões } \\
\text { sobre o que faz. Gosta de ser livre e não ficar dependente dos } \\
\text { outros. }\end{array}$ & 1 & 2 & 3 & 4 & 5 & 6 \\
\hline L & $\begin{array}{l}\text { Um homem para quem é importante ajudar os que o rodeiam. } \\
\text { Gosta de zelar por seu bem-estar. }\end{array}$ & 1 & 2 & 3 & 4 & 5 & 6 \\
\hline$M$ & $\begin{array}{l}\text { Um homem para quem é importante ter sucesso. Gosta de } \\
\text { receber o reconhecimento dos outros. }\end{array}$ & 1 & 2 & 3 & 4 & 5 & 6 \\
\hline $\mathrm{N}$ & $\begin{array}{l}\text { Um homem para quem é importante que o Governo garanta sua } \\
\text { segurança, contra todas as ameaças. Quer que o Estado seja } \\
\text { forte, de modo a defender os cidadãos. }\end{array}$ & 1 & 2 & 3 & 4 & 5 & 6 \\
\hline 0 & $\begin{array}{l}\text { Um homem que procura a aventura e gosta de correr riscos. } \\
\text { Quer ter uma vida emocionante. }\end{array}$ & 1 & 2 & 3 & 4 & 5 & 6 \\
\hline$P$ & $\begin{array}{l}\text { Um homem para quem é importante portar-se sempre da forma } \\
\text { certa. Evita fazer coisas que os outros digam que são erradas. }\end{array}$ & 1 & 2 & 3 & 4 & 5 & 6 \\
\hline $\mathrm{Q}$ & $\begin{array}{l}\text { Um homem para quem é importante que os outros Ihe tenham } \\
\text { respeito. Quer que as pessoas façam o que ele diz. }\end{array}$ & 1 & 2 & 3 & 4 & 5 & 6 \\
\hline $\mathrm{R}$ & $\begin{array}{l}\text { Um homem para quem é importante ser leal com os amigos. } \\
\text { Dedica-se às pessoas que lhe são próximas. }\end{array}$ & 1 & 2 & 3 & 4 & 5 & 6 \\
\hline$S$ & $\begin{array}{l}\text { Um homem que acredita seriamente que as pessoas devem } \\
\text { proteger a natureza. Proteger o ambiente é importante para ele. }\end{array}$ & 1 & 2 & 3 & 4 & 5 & 6 \\
\hline $\mathrm{T}$ & $\begin{array}{l}\text { Um homem que dá importância à tradição. Faz tudo o que pode } \\
\text { para agir de acordo com sua religião e sua família. }\end{array}$ & 1 & 2 & 3 & 4 & 5 & 6 \\
\hline$U$ & $\begin{array}{l}\text { Um homem que procura aproveitar todas as oportunidades para } \\
\text { divertir-se. É importante para ele fazer coisas que lhe dão } \\
\text { prazer. }\end{array}$ & 1 & 2 & 3 & 4 & 5 & 6 \\
\hline
\end{tabular}

\section{SÓ PARA MULHERES RODIZIAR}

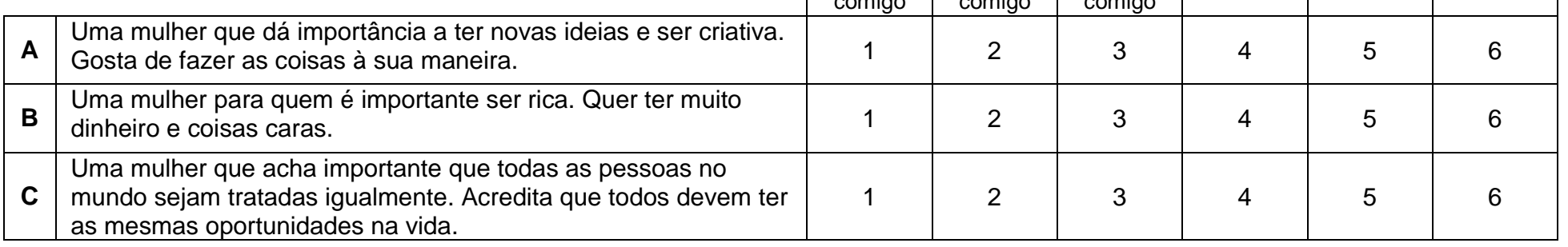




\section{SÓ PARA MULHERES RODIZIAR}

\begin{tabular}{|c|c|c|c|c|c|c|c|}
\hline & & comigo & comigo & comigo & & toringo & \\
\hline D & $\begin{array}{l}\text { Uma mulher que dá muita importância a poder mostrar suas } \\
\text { capacidades. Quer que as pessoas admirem o que faz. }\end{array}$ & 1 & 2 & 3 & 4 & 5 & 6 \\
\hline$E$ & $\begin{array}{l}\text { Uma mulher que dá importância a viver num sítio onde se sinta } \\
\text { segura. Evita tudo o que possa pôr a sua segurança em risco. }\end{array}$ & 1 & 2 & 3 & 4 & 5 & 6 \\
\hline$F$ & $\begin{array}{l}\text { Uma mulher que gosta de surpresas e está sempre à procura de } \\
\text { coisas novas para fazer. Acha que é importante fazer muitas } \\
\text { coisas diferentes na vida. }\end{array}$ & 1 & 2 & 3 & 4 & 5 & 6 \\
\hline $\mathbf{G}$ & $\begin{array}{l}\text { Uma mulher que acha que as pessoas devem fazer o que lhes } \\
\text { mandam. Acha que as pessoas devem cumprir sempre as } \\
\text { regras mesmo quando ninguém está vendo. }\end{array}$ & 1 & 2 & 3 & 4 & 5 & 6 \\
\hline $\mathbf{H}$ & $\begin{array}{l}\text { Uma mulher para quem é importante ouvir pessoas diferentes } \\
\text { de si. Mesmo quando discorda de alguém continua a querer } \\
\text { compreender essa pessoa. }\end{array}$ & 1 & 2 & 3 & 4 & 5 & 6 \\
\hline I & $\begin{array}{l}\text { Uma mulher para quem é importante para ela ser humilde e } \\
\text { modesta. Tenta não chamar a atenções sobre si. }\end{array}$ & 1 & 2 & 3 & 4 & 5 & 6 \\
\hline $\mathrm{J}$ & $\begin{array}{l}\text { Uma mulher para quem é importante para ela passar bons } \\
\text { momentos. Gosta de tratar bem de si.. }\end{array}$ & 1 & 2 & 3 & 4 & 5 & 6 \\
\hline K & $\begin{array}{l}\text { Uma mulher para quem é importante tomar as suas próprias } \\
\text { decisões sobre o que faz. Gosta de ser livre e não estar } \\
\text { dependente dos outros }\end{array}$ & 1 & 2 & 3 & 4 & 5 & 6 \\
\hline $\mathbf{L}$ & $\begin{array}{l}\text { Uma mulher para quem é importante para ela ajudar os que a } \\
\text { rodeiam. Gosta de zelar pelo seu bem-estar }\end{array}$ & 1 & 2 & 3 & 4 & 5 & 6 \\
\hline $\mathbf{M}$ & $\begin{array}{l}\text { Uma mulher para quem é importante para ela ter sucesso. } \\
\text { Gosta de receber o reconhecimento dos outros. }\end{array}$ & 1 & 2 & 3 & 4 & 5 & 6 \\
\hline $\mathbf{N}$ & $\begin{array}{l}\text { Uma mulher para quem é importante que o Governo garanta a } \\
\text { sua segurança, contra todas as ameaças. Quer que o Estado } \\
\text { seja forte, de modo a poder defender os cidadãos. }\end{array}$ & 1 & 2 & 3 & 4 & 5 & 6 \\
\hline 0 & $\begin{array}{l}\text { Uma mulher que procura a aventura e gosta de correr riscos. } \\
\text { Quer ter uma vida emocionante. }\end{array}$ & 1 & 2 & 3 & 4 & 5 & 6 \\
\hline $\mathbf{P}$ & $\begin{array}{l}\text { Uma mulher para quem é importante se portar sempre da forma } \\
\text { correta. Evita fazer coisas que os outros digam que são erradas. }\end{array}$ & 1 & 2 & 3 & 4 & 5 & 6 \\
\hline $\mathbf{Q}$ & $\begin{array}{l}\text { Uma mulher para quem é importante que os outros lhe tenham } \\
\text { respeito. Quer que as pessoas façam o que ela diz. }\end{array}$ & 1 & 2 & 3 & 4 & 5 & 6 \\
\hline $\mathrm{R}$ & $\begin{array}{l}\text { Uma mulher para quem é importante ser leal com os amigos. } \\
\text { Dedica-se às pessoas que lhe são próximas. }\end{array}$ & 1 & 2 & 3 & 4 & 5 & 6 \\
\hline$S$ & $\begin{array}{l}\text { Uma mulher que acredita seriamente que as pessoas devem } \\
\text { proteger a natureza. Proteger o ambiente é importante para ela. }\end{array}$ & 1 & 2 & 3 & 4 & 5 & 6 \\
\hline $\mathrm{T}$ & $\begin{array}{l}\text { Uma mulher que dá importância à tradição. Faz tudo o que pode } \\
\text { para agir de acordo com a sua religião e a sua família. }\end{array}$ & 1 & 2 & 3 & 4 & 5 & 6 \\
\hline$U$ & $\begin{array}{l}\text { Uma mulher que procura aproveitar todas as oportunidades para } \\
\text { divertir-se. É importante para ela fazer coisas que lhe dão } \\
\text { prazer. }\end{array}$ & 1 & 2 & 3 & 4 & 5 & 6 \\
\hline
\end{tabular}

\section{ATITUDE EM RELAÇÃO AO AMBIENTE E À NATUREZA, Ȧ PRODUÇÃO INDUSTRIAL DE COMIDA E AOS AVANÇOS TECNOLÓGICOS}

\section{Q3. Vou ler algumas declarações e gostaria que indicasse o quanto concorda com cada uma delas.}


Você pode responder com um número de 1 a 7 , em que 1 significa "discordo totalmente" e 7 significa "concordo totalmente". Você pode responder com os números intermediários.

1= discordo totalmente

4= Não concordo nem discordo

$7=$ concordo totalmente

1. Os humanos estão abusando muito do meio-ambiente.

2. O equilíbrio da natureza é forte o bastante para aguentar os impactos das nações industrializadas modernas.

3. A chamada "crise ecológica" diante da humanidade tem sido muito exagerada.

4. A Terra é como uma espaçonave com pouco espaço e recursos limitados.

5. Se as coisas continuarem como estão, logo teremos uma grande catástrofe ecológica.

6. Muitos fabricantes de alimentos estão mais interessados em ganhar dinheiro do que na qualidade nutricional de seus produtos.

7. A produção moderna de comida retira vitaminas e minerais dos produtos alimentares.

8. A indústria alimentícia está muito preocupada com o valor nutricional de seus produtos.

9. A maioria dos alimentos é tão processada que perde o valor nutricional.

10. A maioria dos alimentos pode ser consumida sem riscos.

11.O grau de civilização de um povo pode ser medido pelo grau de seu desenvolvimento tecnológico.

12. Novos inventos tecnológicos e aplicações compõem a principal força do progresso da sociedade.

13. No Brasil, estamos provavelmente melhores que nunca, graças aos grandes progressos da tecnologia.

14.Através dos tempos, o conhecimento tecnológico tem sido a arma mais importante na luta pela vida.

15.Por causa do desenvolvimento tecnológico, poderemos enfrentar os problemas da sociedade de amanhã.

\begin{tabular}{|l|l|l|l|l|l|l|}
\hline 1 & 2 & 3 & 4 & 5 & 6 & 7 \\
\hline 1 & 2 & 3 & 4 & 5 & 6 & 7 \\
\hline 1 & 2 & 3 & 4 & 5 & 6 & 7 \\
\hline 1 & 2 & 3 & 4 & 5 & 6 & 7 \\
\hline 1 & 2 & 3 & 4 & 5 & 6 & 7 \\
\hline 1 & 2 & 3 & 4 & 5 & 6 & 7 \\
\hline 1 & 2 & 3 & 4 & 5 & 6 & 7 \\
\hline 1 & 2 & 3 & 4 & 5 & 6 & 7 \\
\hline 1 & 2 & 3 & 4 & 5 & 6 & 7 \\
\hline 1 & 2 & 3 & 4 & 5 & 6 & 7 \\
\hline 1 & 2 & 3 & 4 & 5 & 6 & 7 \\
\hline 1 & 2 & 3 & 4 & 5 & 6 & 7 \\
\hline 1 & 2 & 3 & 4 & 5 & 6 & 7 \\
\hline 1 & 2 & 3 & 4 & 5 & 6 & 7 \\
\hline 1 & 2 & 3 & 4 & 5 & 6 & 7 \\
\hline
\end{tabular}

\section{ETNOCENTRISMO}

Q4. Vou ler algumas declarações sobre produtos brasileiros. Gostaria que indicasse o quanto concorda com cada declaração. Você pode responder com um número de $1 \mathrm{a} 7$, em que 1 significa "discordo totalmente" e 7 significa "concordo totalmente". Você pode responder com os números intermediários.

\section{1= discordo totalmente $\quad 4=$ Não concordo nem discordo $\quad 7=$ concordo totalmente}

\section{ENTREVISTADOR: FAÇA RODÍZIO}

1.Compre produtos feitos no Brasil. Mantenha o país funcionando.

2.Consumidores brasileiros que compram produtos feitos em outros países são responsáveis por deixar os colegas brasileiros sem emprego.

3.Comprar produtos produzidos no Brasil ajuda no sustento de comunidades locais.

4. Produtos brasileiros acima de tudo.

5.Um brasileiro de verdade deve comprar sempre produtos feitos no Brasil.

6.Devemos comprar produtos feitos no Brasil em vez de deixar outros países ficarem ricos a nossas custas.

\begin{tabular}{|l|l|l|l|l|l|l|}
\hline 1 & 2 & 3 & 4 & 5 & 6 & 7 \\
\hline 1 & 2 & 3 & 4 & 5 & 6 & 7 \\
\hline 1 & 2 & 3 & 4 & 5 & 6 & 7 \\
1 & 2 & 3 & 4 & 5 & 6 & 7 \\
\hline 1 & 2 & 3 & 4 & 5 & 6 & 7 \\
\hline 1 & 2 & 3 & 4 & 5 & 6 & 7 \\
\hline
\end{tabular}




\begin{tabular}{|l|l|l|l|l|l|l|l|}
\hline 7.É sempre melhor comprar produtos brasileiros. & 1 & 2 & 3 & 4 & 5 & 6 & 7 \\
\hline 8.Isso pode me custar a longo-prazo, mas prefiro apoiar produtos brasileiros. & 1 & 2 & 3 & 4 & 5 & 6 & 7 \\
\hline
\end{tabular}

\section{PARTE 6}

Continuamos com você indicando o quanto concorda com cada declaração.

Você pode responder com um número de 1 a 7 , ondem que 1 significa "discordo totalmente" e 7 significa "concordo totalmente". Você pode responder com os números intermediários.

Q5. É importante que toda comida que eu como normalmente...

1= discordo totalmente $\quad 4=$ Não concordo nem discordo $\quad 7=$ concordo totalmente

\begin{tabular}{|l|l|l|l|l|l|l|l|}
\hline 1. Seja preparada de modo que não prejudique o meio ambiente. & 1 & 2 & 3 & 4 & 5 & 6 & 7 \\
\hline 2. Seja produzida de modo que não interfira no equilíbrio da natureza. & 1 & 2 & 3 & 4 & 5 & 6 & 7 \\
\hline 3. Seja embalada de modo que não prejudique o meio ambiente. & 1 & 2 & 3 & 4 & 5 & 6 & 7 \\
\hline
\end{tabular}

PARTE 7

Q6. Vou ler alguns textos e gostaria de saber se você gosta ou não gosta deste modo de criação de suínos em particular. Você pode responder com um número -5 a 5 , em que -5 significa "não gostei mesmo" e 5 significa "gostei muito". 0 significa "não gostei nem gostei". Mas pode responder -4, -3, -2 e 1 , que significa o quanto você não gostou. Como pode responder 1, 2, 3 e 4, que seriam os intermediarios que você gostou.

-5 "Não gostei nem um pouco " 0 "não gostei nem desgostei” 5 "Gostei muito"

\begin{tabular}{|c|c|c|c|c|c|c|c|c|c|c|c|}
\hline & $\begin{array}{c}\text { Cod } \\
1\end{array}$ & $\begin{array}{c}\text { Cod } \\
2 \\
\end{array}$ & $\begin{array}{c}\text { Cod } \\
3 \\
\end{array}$ & $\begin{array}{c}\text { Cod } \\
4\end{array}$ & $\begin{array}{c}\text { Cod } \\
5\end{array}$ & $\begin{array}{c}\text { Cod } \\
6\end{array}$ & $\begin{array}{c}\text { Cod } \\
7 \\
\end{array}$ & $\begin{array}{c}\text { Cod } \\
8\end{array}$ & $\begin{array}{c}\text { Cod } \\
9\end{array}$ & $\begin{array}{c}\text { Cod } \\
10\end{array}$ & $\begin{array}{c}\text { Cod } \\
11 \\
\end{array}$ \\
\hline & -5 & -4 & -3 & -2 & -1 & 0 & 1 & 2 & 3 & 4 & 5 \\
\hline $\begin{array}{l}1 \text { - Considere uma granja com cerca de } 400 \text { suínos. Os animais } \\
\text { sao alojados em piso com palha. Há algum esforço para reduzir } \\
\text { o impacto ambiental do sistema de produção no solo, água e ar. } \\
\text { A alimentação dos suínos visa produzir carne com teor de } \\
\text { gordura padrão. A granja cria os suínos sempre com qualidade } \\
\text { da carne similar. }\end{array}$ & -5 & -4 & -3 & -2 & -1 & 0 & 1 & 2 & 3 & 4 & 5 \\
\hline $\begin{array}{l}\text { 2- Considere uma granja com cerca de } 400 \text { suínos. Os animais } \\
\text { sao alojados em piso ripado (de madeira ou metal). O esforço } \\
\text { para reduzir o impacto ambiental do sistema de produção no } \\
\text { solo, água e ar é máximo. A alimentação dos suínos visa } \\
\text { produzir carne com teor de gordura padrão. A granja produz } \\
\text { suínos com a qualidade da carne exigida por seus clientes } \\
\text { principais. }\end{array}$ & -5 & -4 & -3 & -2 & -1 & 0 & 1 & 2 & 3 & 4 & 5 \\
\hline $\begin{array}{l}3 \text { - Considere uma granja pequena com menos de } 100 \text { suínos e } \\
\text { outras criações. Os animais sao alojados em piso com palha. O } \\
\text { esforço para reduzir o impacto ambiental do sistema de } \\
\text { produção no solo, água e ar é máximo. A alimentação dos } \\
\text { suínos visa produzir carne com teor de gordura padrão. A granja } \\
\text { produz suínos com qualidade diferente por causa de variações } \\
\text { biológicas e mudança das condições locais. }\end{array}$ & -5 & -4 & -3 & -2 & -1 & 0 & 1 & 2 & 3 & 4 & 5 \\
\hline $\begin{array}{l}\text { 4- Considere uma granja com mais de } 800 \text { suínos e mão de } \\
\text { obra contratada. Os animais têm acesso a uma area externa (ao }\end{array}$ & -5 & -4 & -3 & -2 & -1 & 0 & 1 & 2 & 3 & 4 & 5 \\
\hline
\end{tabular}




\begin{tabular}{|c|c|c|c|c|c|c|c|c|c|c|c|}
\hline $\begin{array}{l}\text { ar livre). O esforço para reduzir o impacto ambiental do sistema } \\
\text { de produção no solo, água e ar é máximo. A alimentação dos } \\
\text { suínos visa produzir carne com gordura saudável (com ômega } 3 \text {, } \\
\text { por exemplo). A granja cria suínos sempre com qualidade da } \\
\text { carne similar }\end{array}$ & & & & & & & & & & & \\
\hline $\begin{array}{l}\text { 5- Considere uma granja pequena com menos de } 100 \text { porcos e } \\
\text { outras criações. Os animais sao alojados em piso ripado (de } \\
\text { madeira ou metal). O esforço para reduzir o impacto ambiental } \\
\text { do sistema de produção no solo, água e ar é mínimo. A } \\
\text { alimentação dos suínos visa produzir carne com teor de gordura } \\
\text { padrão. A granja cria suínos sempre com qualidade da carne } \\
\text { similar. }\end{array}$ & -5 & -4 & -3 & -2 & -1 & 0 & 1 & 2 & 3 & 4 & 5 \\
\hline $\begin{array}{l}\text { 6- Considere uma granja pequena com menos de } 100 \text { suínos e } \\
\text { outras criações. Os animais sao alojados em piso ripado (de } \\
\text { madeira ou metal). Há algum esforço para reduzir o impacto } \\
\text { ambiental do sistema de produção no solo, água e ar. A } \\
\text { alimentação dos suínos visa produzir carne com gordura } \\
\text { saudável (com ômega 3, por exemplo). A granja cria suínos } \\
\text { sempre com qualidade da carne similar }\end{array}$ & -5 & -4 & -3 & -2 & -1 & 0 & 1 & 2 & 3 & 4 & 5 \\
\hline $\begin{array}{l}\text { 7- Considere uma granja com mais de } 800 \text { suínos com mão de } \\
\text { obra contratada. Os animais sao alojados em piso ripado (de } \\
\text { madeira ou metal). Há algum esforço para reduzir o impacto } \\
\text { ambiental do sistema de produção no solo, água e ar. A } \\
\text { alimentação dos suínos visa produzir carne com teor de gordura } \\
\text { padrão. A granja produz suínos com a qualidade exigida apenas } \\
\text { por seus clientes principais }\end{array}$ & -5 & -4 & -3 & -2 & -1 & 0 & 1 & 2 & 3 & 4 & 5 \\
\hline $\begin{array}{l}\text { 8- Considere uma granja pequena com menos de } 100 \text { suínos e } \\
\text { outras criações. Os animais têm acesso a uma area externa (ao } \\
\text { ar livre). O esforço para reduzir o impacto ambiental do sistema } \\
\text { de produção no solo, água e ar é mínimo. A alimentação dos } \\
\text { suínos visa produzir carne com baixo teor de gordura (light). A } \\
\text { granja produz suínos com a qualidade exigida apenas por seus } \\
\text { clientes principais }\end{array}$ & -5 & -4 & -3 & -2 & -1 & 0 & 1 & 2 & 3 & 4 & 5 \\
\hline $\begin{array}{l}\text { 9- Considere uma granja pequena com menos de } 100 \text { suínos e } \\
\text { outras criações. Os animais têm acesso a uma area externa (ao } \\
\text { ar livre). Há algum esforço para reduzir o impacto ambiental do } \\
\text { sistema de produção no solo, água e ar. A alimentação dos } \\
\text { suínos visa produzir carne com teor de gordura padrão. A granja } \\
\text { cria suínos com qualidade diferente por causa de variações } \\
\text { biológicas e mudança das condições locais. }\end{array}$ & -5 & -4 & -3 & -2 & -1 & 0 & 1 & 2 & 3 & 4 & 5 \\
\hline $\begin{array}{l}\text { 10- Considere uma granja com cerca de } 400 \text { suínos. Os animais } \\
\text { têm acesso a uma area externa (ao ar livre). O esforço para } \\
\text { reduzir o impacto ambiental do sistema de produção no solo, } \\
\text { água e ar é mínimo. A alimentação dos suínos visa produzir } \\
\text { carne com teor de gordura padrão. A granja cria suínos sempre } \\
\text { com qualidade da carne similar. }\end{array}$ & -5 & -4 & -3 & -2 & -1 & 0 & 1 & 2 & 3 & 4 & 5 \\
\hline $\begin{array}{l}\text { 11- Considere uma granja com mais de } 800 \text { suínos e mão de } \\
\text { obra contratada. Os animais sao alojados em piso ripado (de } \\
\text { madeira ou metal). O esforço para reduzir o impacto ambiental } \\
\text { do sistema de produção no solo, água e ar é mínimo. A } \\
\text { alimentação dos suínos visa produzir carne com baixo teor de } \\
\text { gordura (light). A granja cria suínos com qualidade diferente por } \\
\text { causa de variações biológicas e mudança das condições locais. }\end{array}$ & -5 & -4 & -3 & -2 & -1 & 0 & 1 & 2 & 3 & 4 & 5 \\
\hline $\begin{array}{l}\text { 12- Considere uma granja com cerca de } 400 \text { suínos. Os animais } \\
\text { são alojados em piso ripado (de madeira ou metal). O esforço } \\
\text { para reduzir o impacto ambiental do sistema de produção no } \\
\text { solo, água e ar é mínimo. A alimentação dos suínos visa } \\
\text { produzir carne com gordura saudável (com ômega 3, por } \\
\text { exemplo). A granja cria suínos com qualidade diferente por } \\
\text { causa de variações biológicas e mudança das condições locais. }\end{array}$ & -5 & -4 & -3 & -2 & -1 & 0 & 1 & 2 & 3 & 4 & 5 \\
\hline $\begin{array}{l}\text { 13- Considere uma granja pequena com menos de } 100 \text { suínos e } \\
\text { outras criações. Os animais sao alojados em piso ripado (de }\end{array}$ & -5 & -4 & -3 & -2 & -1 & 0 & 1 & 2 & 3 & 4 & 5 \\
\hline
\end{tabular}


madeira ou metal). O esforço para reduzir o impacto ambiental do sistema de produção no solo, água e ar é máximo. A alimentação dos suínos visa produzir carne com baixo teor de gordura (light). A granja cria suínos sempre com qualidade da carne similar.

14- Considere uma granja com mais de 800 suínos e mão de obra contratada. Os animais sao alojados em piso com palha. $O$ esforço para reduzir o impacto ambiental do sistema de produção no solo, água e ar é mínimo. A alimentação dos suínos visa produzir carne com teor de gordura padrão. A granja cria suínos sempre com qualidade da carne similar.

15- Considere uma granja pequena com menos de 100 suínos e outras criações. Os animais sao alojados em piso com palha. $O$ esforço para reduzir o impacto ambiental do sistema de produção no solo, água e ar é mínimo. A alimentação dos suínos visa produzir carne com gordura saudável (com ômega 3, por exemplo). A granja cria suínos sempre com qualidade da carne similar.

\begin{tabular}{|l|l|l|l|l|l|l|l|l|l|l|}
\hline & & & & & & & & & \\
\hline-5 & -4 & -3 & -2 & -1 & 0 & 1 & 2 & 3 & 4 & 5 \\
-5 & -4 & -3 & -2 & -1 & 0 & 1 & 2 & 3 & 4 & 5 \\
\hline
\end{tabular}

\section{PARTE 8 - QUESTÓES PRELIMINARES SOBRE O PRODUTO}

Q7. Você conhece algum produtor de suínos/porcos? (RU)

\begin{tabular}{|l|l|l|l|l|l|}
\hline 1 & $\operatorname{Sim}$ & 2 & Não & 3 & Não sei \\
\hline
\end{tabular}

Q8. Mora perto de alguma criação de suínos/porcos? (RU)

\begin{tabular}{|l|l|l|l|l|l|}
\hline 1 & Sim & 2 & Não & 3 & Não sei \\
\hline
\end{tabular}

Q9. Você come carne de porco? (RU)

\begin{tabular}{|l|l|l|}
\hline $\mathbf{1 .}$ & Sim & VÁ PARA A PRÓXIMA PARTE: CONSUMO DE CARNE DE PORCO \\
\hline $\mathbf{2 .}$ & Não & AGRADEÇA E ENCERRE \\
\hline $\mathbf{3 .}$ & Não sei & AGRADEÇA E ENCERRE \\
\hline
\end{tabular}

\section{CONSUMO DE CARNE DE PORCO}

Q10. Por gentileza, indique, em cada produto que eu ler, o quanto costuma comê-lo. Se tiver dificuldade para definir com exatidão, por gentileza, baseie-se no ano passado e/ou na semana passada.

Com que FREQUÊNCIA você come? (RU) - CARTÃO PERG. 10

\begin{tabular}{|l|c|c|c|c|c|c|c|c|c|}
\hline \multicolumn{1}{|c|}{ Faça Rodízio } & \multicolumn{1}{|c|}{$\begin{array}{c}\mathbf{1} \\
\text { Nunca }\end{array}$} & $\begin{array}{c}\mathbf{2} \\
\text { Anualmente } \\
\text { ou com } \\
\text { menos } \\
\text { frequência }\end{array}$ & $\begin{array}{c}\mathbf{3} \\
\text { Muitas } \\
\text { vezes } \\
\text { por ano }\end{array}$ & $\begin{array}{c}\mathbf{4} \\
\text { Mensa } \\
\text { Imente }\end{array}$ & $\begin{array}{c}\mathbf{5} \\
\text { Muitas } \\
\text { vezes } \\
\text { por } \\
\text { mês }\end{array}$ & $\begin{array}{c}\mathbf{6} \\
\text { Sema } \\
\text { nalme } \\
\text { nte }\end{array}$ & $\begin{array}{c}\mathbf{7} \\
\text { Muitas } \\
\text { vezes } \\
\text { por } \\
\text { semana }\end{array}$ & $\begin{array}{c}\mathbf{8} \\
\text { Diaria } \\
\text { mente }\end{array}$ \\
\hline PRIMEIROS CORTES FRESCOS & 1 & 2 & 3 & 4 & 5 & 6 & 7 & 8 \\
\hline 1. Costela de porco & 1 & 2 & 3 & 4 & 5 & 6 & 7 & 8 \\
\hline 2. Paleta, lombo, bisteca & & &
\end{tabular}




\begin{tabular}{|c|c|c|c|c|c|c|c|c|}
\hline 3. Pernil & 1 & 2 & 3 & 4 & 5 & 6 & 7 & 8 \\
\hline 4. Outros (miúdos, toucinho, rabo, orelha) & 1 & 2 & 3 & 4 & 5 & 6 & 7 & 8 \\
\hline \multicolumn{9}{|l|}{ FRESCOS E POUCO PROCESSADOS } \\
\hline $\begin{array}{l}\text { 5.Exemplos: linguiças, espetinho, carne } \\
\text { embalada a vácuo, salsichão, carne de } \\
\text { porco moída }\end{array}$ & 1 & 2 & 3 & 4 & 5 & 6 & 7 & 8 \\
\hline \multicolumn{9}{|l|}{ MAIS PROCESSADOS } \\
\hline $\begin{array}{l}\text { 6. Exemplo: carne recheada, escalope, } \\
\text { carne assada, espetinho, marinados, } \\
\text { temperados }\end{array}$ & 1 & 2 & 3 & 4 & 5 & 6 & 7 & 8 \\
\hline \multicolumn{9}{|l|}{ REFEIÇÕES } \\
\hline $\begin{array}{l}\text { 7. Exemplo: lasanha, pizza, macarronada, } \\
\text { feijoada }\end{array}$ & 1 & 2 & 3 & 4 & 5 & 6 & 7 & 8 \\
\hline \multicolumn{9}{|l|}{ PRODUTOS DE CARNE } \\
\hline 8.1. Frios (salame, presunto, mortadela) & 1 & 2 & 3 & 4 & 5 & 6 & 7 & 8 \\
\hline 8.2. Bacon & 1 & 2 & 3 & 4 & 5 & 6 & 7 & 8 \\
\hline 8.3. Salsichas e linguiças & 1 & 2 & 3 & 4 & 5 & 6 & 7 & 8 \\
\hline 8.4. Patê & 1 & 2 & 3 & 4 & 5 & 6 & 7 & 8 \\
\hline
\end{tabular}

\section{FILTRO: PARA AS PRÓXIMAS QUESTÕES (11 a 22), PERGUNTE APENAS SOBRE OS PRODUTOS QUE RECEBERAM CÓDIGO 3 a 8 NA QUESTÃO 10)}

Q11. Você (ou seus familiares) normalmente compra esse produto fresco ou congelado? Como este produto É NORMALMENTE COMPRADO em sua casa?

\begin{tabular}{|c|c|c|}
\hline & $\begin{array}{l}1 . \\
\text { Fresco/Resfriado }\end{array}$ & $\begin{array}{c}2 . \\
\text { Congelado }\end{array}$ \\
\hline \multicolumn{3}{|l|}{ PRIMEIROS CORTES FRESCOS } \\
\hline 1. Costela de porco & 1 & 2 \\
\hline 2. Paleta, lombo, bisteca & 1 & 2 \\
\hline 3. Pernil & 1 & 2 \\
\hline 4. Outros (miúdos, toucinho, rabo, orelha) & 1 & 2 \\
\hline \multicolumn{3}{|l|}{ FRESCOS E POUCO PROCESSADOS } \\
\hline $\begin{array}{l}\text { 5. Exemplos: linguiças, espetinho, carne embalada a vácuo, } \\
\text { salsichão, carne de porco moída }\end{array}$ & 1 & 2 \\
\hline \multicolumn{3}{|l|}{ MAIS PROCESSADOS } \\
\hline $\begin{array}{l}\text { 6. Exemplo: carne recheada, escalope, carne assada, espetinho, } \\
\text { marinados, temperados }\end{array}$ & 1 & 2 \\
\hline \multicolumn{3}{|l|}{ REFEIÇÕES } \\
\hline 7. Exemplo: lasanha, pizza, macarronada, feijoada & 1 & 2 \\
\hline \multicolumn{3}{|l|}{ PRODUTOS RESFRIADOS } \\
\hline 8.1. Frios (salame, presunto, mortadela) & 1 & 2 \\
\hline 8.2. Bacon & 1 & 2 \\
\hline 8.3. Salsichas e linguiças & 1 & 2 \\
\hline
\end{tabular}


Q12. Onde você (ou seus familiares) normalmente compra cada um desses produtos? (RU) LER LOCAIS

\begin{tabular}{|c|c|c|c|}
\hline & $\begin{array}{c}1 . \\
\text { No açougue }\end{array}$ & $\begin{array}{c}\text { 2. No } \\
\text { supermercado }\end{array}$ & $\begin{array}{l}\text { 3. Em outro lugar } \\
\text { diferente }\end{array}$ \\
\hline \multicolumn{4}{|l|}{ PRIMEIROS CORTES FRESCOS } \\
\hline 1. Costela de porco & 1 & 2 & 3 \\
\hline 2. Paleta, lombo, bisteca & 1 & 2 & 3 \\
\hline 3. Pernil & 1 & 2 & 3 \\
\hline 4. Outros (miúdos, toucinho, rabo, orelha) & 1 & 2 & 3 \\
\hline \multicolumn{4}{|l|}{ FRESCOS E POUCO PROCESSADOS } \\
\hline $\begin{array}{l}\text { 5. Exemplos: linguiças, salsichão, carne } \\
\text { embalada a vácuo, carne de porco moída }\end{array}$ & 1 & 2 & 3 \\
\hline \multicolumn{4}{|l|}{ MAIS PROCESSADOS } \\
\hline $\begin{array}{l}\text { 6. Exemplo: carne recheada, escalope, carne } \\
\text { assada, espetinho }\end{array}$ & 1 & 2 & 3 \\
\hline \multicolumn{4}{|l|}{ REFEIÇÕES } \\
\hline $\begin{array}{l}\text { 7. Exemplo: lasanha, pizza, macarronada, } \\
\text { feijoada }\end{array}$ & 1 & 2 & 3 \\
\hline \multicolumn{4}{|l|}{ PRODUTOS DE CARNE } \\
\hline 8.1. Frios (salame, presunto, mortadela) & 1 & 2 & 3 \\
\hline 8.2. Bacon & 1 & 2 & 3 \\
\hline 8.3. Salsichas e linguiças & 1 & 2 & 3 \\
\hline 8.4. Patê & 1 & 2 & 3 \\
\hline
\end{tabular}

Q13. Quando você normalmente consome esses produtos? (RU) LER ALTERNATIVAS

\begin{tabular}{|c|c|c|c|c|}
\hline & $\begin{array}{l}\text { 1. Uma vez } \\
\text { por semana }\end{array}$ & $\begin{array}{c}2 . \\
\begin{array}{c}\text { Qualquer } \\
\text { dia }\end{array}\end{array}$ & $\begin{array}{l}\text { 3. Nos } \\
\text { finais de } \\
\text { semana }\end{array}$ & $\begin{array}{l}\text { 4. Apenas em } \\
\text { ocasiões } \\
\text { especiais }\end{array}$ \\
\hline \multicolumn{5}{|l|}{ PRIMEIROS CORTES FRESCOS } \\
\hline 1. Costela de porco & 1 & 2 & 3 & 4 \\
\hline 2. Paleta, lombo, bisteca & 1 & 2 & 3 & 4 \\
\hline 3. Pernil & 1 & 2 & 3 & 4 \\
\hline 4. Outros (miúdos, toucinho, rabo, orelha) & 1 & 2 & 3 & 4 \\
\hline \multicolumn{5}{|l|}{ FRESCOS E POUCO PROCESSADOS } \\
\hline $\begin{array}{l}\text { 5. Exemplos: linguiças, salsichão, carne embalada a } \\
\text { vácuo, carne de porco moída }\end{array}$ & 1 & 2 & 3 & 4 \\
\hline \multicolumn{5}{|l|}{ MAIS PROCESSADOS } \\
\hline $\begin{array}{l}\text { 6. Exemplo: carne recheada, escalope, carne assada, } \\
\text { espetinho }\end{array}$ & 1 & 2 & 3 & 4 \\
\hline \multicolumn{5}{|l|}{ REFEIÇÕES } \\
\hline 7. Exemplo: lasanha, pizza, macarronada, feijoada & 1 & 2 & 3 & 4 \\
\hline
\end{tabular}


PRODUTOS DE CARNE

8.1. Frios (salame, presunto, mortadela)

8.2. Bacon

8.3. Salsichas e linguiças

8.4. Patê

\begin{tabular}{|l|l|l|l|}
\hline & & & \\
\hline 1 & 2 & 3 & 4 \\
\hline 1 & 2 & 3 & 4 \\
\hline 1 & 2 & 3 & 4 \\
\hline
\end{tabular}

Q14. Na COMPANHIA de quem você normalmente come esses produtos? (RU)

\begin{tabular}{|c|c|c|c|c|}
\hline & 1. Sozinha & $\begin{array}{l}\text { 2. Com } \\
\text { família }\end{array}$ & $\begin{array}{l}\text { 3. Com } \\
\text { amigos }\end{array}$ & $\begin{array}{l}\text { 4. Em outra } \\
\text { companhia }\end{array}$ \\
\hline \multicolumn{5}{|l|}{ PRIMEIROS CORTES FRESCOS } \\
\hline 1. Costela de porco & 1 & 2 & 3 & 4 \\
\hline 2. Paleta, lombo, bisteca & 1 & 2 & 3 & 4 \\
\hline 3. Pernil & 1 & 2 & 3 & 4 \\
\hline 4. Outros (miúdos, toucinho, rabo, orelha) & 1 & 2 & 3 & 4 \\
\hline \multicolumn{5}{|l|}{ FRESCOS E POUCO PROCESSADOS } \\
\hline $\begin{array}{l}\text { 5. Exemplos: linguiças, salsichão, carne embalada } \\
\text { a vácuo, carne de porco moída }\end{array}$ & 1 & 2 & 3 & 4 \\
\hline \multicolumn{5}{|l|}{ MAIS PROCESSADOS } \\
\hline $\begin{array}{l}\text { 6. Exemplo: carne recheada, escalope, carne } \\
\text { assada, espetinho }\end{array}$ & 1 & 2 & 3 & 4 \\
\hline \multicolumn{5}{|l|}{ REFEIÇÕES } \\
\hline 7. Exemplo: lasanha, pizza, macarronada, feijoada & 1 & 2 & 3 & 4 \\
\hline \multicolumn{5}{|l|}{ PRODUTOS DE CARNE } \\
\hline 8.1. Frios (salame, presunto, mortadela) & 1 & 2 & 3 & 4 \\
\hline 8.2. Bacon & 1 & 2 & 3 & 4 \\
\hline 8.3. Salsichas e linguiças & 1 & 2 & 3 & 4 \\
\hline 8.4. Patê & 1 & 2 & 3 & 4 \\
\hline
\end{tabular}

Q15. Agora queremos saber ONDE você costuma comer esses produtos. (RU) LER

\begin{tabular}{|c|c|c|c|c|}
\hline & 1. Em casa & $\begin{array}{l}\text { 2. Em um } \\
\text { restaurante }\end{array}$ & $\begin{array}{l}\text { 3. "para } \\
\text { viagem" }\end{array}$ & $\begin{array}{l}\text { 4. Em outro } \\
\text { lugar }\end{array}$ \\
\hline \multicolumn{5}{|l|}{ PRIMEIROS CORTES FRESCOS } \\
\hline 1. Costela de porco & 1 & 2 & 3 & 4 \\
\hline 2. Paleta, lombo, bisteca & 1 & 2 & 3 & 4 \\
\hline 3. Pernil & 1 & 2 & 3 & 4 \\
\hline 4. Outros (miúdos, toucinho, rabo, orelha) & 1 & 2 & 3 & 4 \\
\hline \multicolumn{5}{|l|}{ FRESCOS E POUCO PROCESSADOS } \\
\hline $\begin{array}{l}\text { 5. Exemplos: lingüuiças, salsichão, carne embalada a } \\
\text { vácuo, carne de porco moída }\end{array}$ & 1 & 2 & 3 & 4 \\
\hline
\end{tabular}

\begin{tabular}{|l|c|c|c|c|}
\hline & 1. Em casa & $\begin{array}{c}\text { 2. Em um } \\
\text { restaurante }\end{array}$ & $\begin{array}{c}\text { 3. "para } \\
\text { viagem" }\end{array}$ & $\begin{array}{c}\text { 4. Em outro } \\
\text { lugar }\end{array}$ \\
\hline MAIS PROCESSADOS & & & & \\
\hline $\begin{array}{l}\text { 6. Exemplo: carne recheada, escalope, carne assada, } \\
\text { espetinho }\end{array}$ & 1 & 2 & 3 & 4 \\
\hline REFEIÇÕES & & & & \\
\hline 7.Exemplo: lasanha, pizza, macarronada, feijoada & 1 & 2 & 3 & 4 \\
\hline PRODUTOS DE CARNE & & & & \\
\hline 8.1 Frios (salame, presunto, mortadela) & 1 & 2 & 3 & 4 \\
\hline
\end{tabular}




\begin{tabular}{|l|l|l|l|l|}
\hline 8.2. Bacon & 1 & 2 & 3 & 4 \\
\hline 8.3. Salsichas e linguiças & 1 & 2 & 3 & 4 \\
\hline 8.4. Patê & 1 & 2 & 3 & 4 \\
\hline
\end{tabular}

Q16. Como você COSTUMA PREPARAR esses produtos em casa? (RU). LER

\begin{tabular}{|c|c|c|c|}
\hline & $\begin{array}{l}\text { 1. É preparado em } \\
\text { casa desde o } \\
\text { início, antes de } \\
\text { ser consumido }\end{array}$ & $\begin{array}{l}\text { 2. É finalizado em } \\
\text { casa antes de ser } \\
\text { consumido }\end{array}$ & $\begin{array}{l}\text { 3. É comprado pronto } \\
\text { para o consumo }\end{array}$ \\
\hline \multicolumn{4}{|l|}{ PRIMEIROS CORTES FRESCOS } \\
\hline 1. Costela de porco & 1 & 2 & 3 \\
\hline 2. Paleta, lombo, bisteca & 1 & 2 & 3 \\
\hline 3. Pernil & 1 & 2 & 3 \\
\hline 4. Outros (miúdos, toucinho, rabo, orelha) & 1 & 2 & 3 \\
\hline \multicolumn{4}{|l|}{ FRESCOS E POUCO PROCESSADOS } \\
\hline $\begin{array}{l}\text { 5. Exemplos: linguiças, salsichão, carne } \\
\text { embalada a vácuo, carne de porco moída }\end{array}$ & 1 & 2 & 3 \\
\hline \multicolumn{4}{|l|}{ MAIS PROCESSADOS } \\
\hline $\begin{array}{l}\text { 6. Exemplo: carne recheada, escalope, carne } \\
\text { assada, espetinho }\end{array}$ & 1 & 2 & 3 \\
\hline \multicolumn{4}{|l|}{ REFEIÇÕES } \\
\hline $\begin{array}{l}\text { 7. Exemplo: lasanha, pizza, macarronada, } \\
\text { feijoada }\end{array}$ & 1 & 2 & 3 \\
\hline \multicolumn{4}{|l|}{ PRODUTOS DE CARNE } \\
\hline 8.1. Frios (salame, presunto, mortadela) & 1 & 2 & 3 \\
\hline 8.2. Bacon & 1 & 2 & 3 \\
\hline 8.3. Salsichas e linguiças & 1 & 2 & 3 \\
\hline 8.4. Patê & 1 & 2 & 3 \\
\hline
\end{tabular}

Q17. Quanto você está satisfeito com relação a diferentes aspectos de cada um desses produtos? No geral, quanto está satisfeito com este produto?

Você pode responder com um número de 1 a 7 , em que 1 significa "nem um pouco satisfeito" e 7 significa "muito satisfeito". Você pode responder com os números intermediários.

Entrevistador : FAÇA AS PERGUNTAS DE 17 A 21 EM SEQUÊNCIA PARA UM PRODUTO, ANTES

DE PASSAR PARA O PRODUTO SEGUINTE - PERGUNTE APENAS SOBRE OS PRODUTOS QUE

RECEBERAM CÓDIGOS DE 3 A 8 NA QUESTÃO 10)

$1=$ Nem um pouco satisfeito $4=$ Nem satisfeito nem insatisfeito $7=$ Muito satisfeito

PRIMEIROS CORTES FRESCOS

1. Costela de porco

2. Paleta, lombo, bisteca

3. Pernil

4. Outros (miúdos, toucinho, rabo, orelha)

FRESCOS E POUCO PROCESSADOS

5.Exemplos: linguiças, espetinho, carne embalada a vácuo, salsichão, carne de porco moída

\begin{tabular}{|l|l|l|l|l|l|l|}
\hline $\mathbf{1}$ & $\mathbf{2}$ & $\mathbf{3}$ & $\mathbf{4}$ & $\mathbf{5}$ & $\mathbf{6}$ & $\mathbf{7}$ \\
\hline 1 & 2 & 3 & 4 & 5 & 6 & 7 \\
\hline 1 & 2 & 3 & 4 & 5 & 6 & 7 \\
\hline 1 & 2 & 3 & 4 & 5 & 6 & 7 \\
\hline 1 & 2 & 3 & 4 & 5 & 6 & 7 \\
\hline 1 & 2 & 3 & 4 & 5 & 6 & 7 \\
\hline
\end{tabular}

MAIS PROCESSADOS

6.Exemplo: carne recheada, escalope, carne assada,

$1 \quad-2$

3

4

5

6

7


espetinho, marinados, temperados

REFEIÇOES

7.Exemplo: lasanha, pizza, macarronada, feijoada

PRODUTOS DE CARNE

8. Frios (salame, presunto, mortadela)

8.1. Bacon

8.2. Salsichas e linguiças

8.3. Patê

\begin{tabular}{l|l|l|l|l|l|l|l|}
\hline & & & & & & \\
\hline & 1 & 2 & 3 & 4 & 5 & 6 & 7 \\
\hline & 1 & 2 & 3 & 4 & 5 & 6 & 7 \\
\hline & 1 & 2 & 3 & 4 & 5 & 6 & 7 \\
\hline & 2 & 3 & 4 & 5 & 6 & 7 \\
\hline
\end{tabular}

Q.18 Quanto está satisfeito com o SABOR do produto?

Você pode responder com um número de $1 \mathrm{a} 7$, em que 1 significa "nem um pouco satisfeito" e 7

significa "muito satisfeito". Você pode responder com os números intermediários. (RU)

1= Nem um pouco satisfeito $4=$ Nem satisfeito nem insatisfeito $7=$ Muito satisfeito

PRIMEIROS CORTES FRESCOS

\begin{tabular}{|l|l|l|l|l|l|l|l|}
\hline 1. Costela de porco & 1 & 2 & 3 & 4 & 5 & 6 & 7 \\
\hline 2. Paleta, lombo, bisteca & 1 & 2 & 3 & 4 & 5 & 6 & 7 \\
\hline 3. Pernil & 1 & 2 & 3 & 4 & 5 & 6 & 7 \\
\hline 4. Outros (miúdos, toucinho, rabo, orelha) & 1 & 2 & 3 & 4 & 5 & 6 & 7 \\
\hline
\end{tabular}

FRESCOS E POUCO PROCESSADOS

5.Exemplos: linguiças, espetinho, carne embalada a vácuo, salsichão, carne de porco moída

MAIS PROCESSADOS

6.Exemplo: carne recheada, escalope, carne assada,

espetinho, marinados, temperados

REFEIÇOES

7.Exemplo: Iasanha, pizza, macarronada, feijoada

PRODUTOS DE CARNE

8.1. Frios (salame, presunto, mortadela)

8.2. Bacon

8.3. Salsichas e linguiças

8.4. Patê

\begin{tabular}{l|l|l}
1 & &
\end{tabular}

2

3

\begin{tabular}{|l|l|l|l}
4 & 5 \\
\hline
\end{tabular}

5

6

7

Q.19 Quanto está satisfeito com as QUALIDADES SAUDÁVEIS desse produto?

Você pode responder com um número de 1 a 7 , em que 1 significa "nem um pouco satisfeito" e 7 significa "muito satisfeito". Você pode responder com os números intermediários. (RU)

1= Nem um pouco satisfeito $4=$ Nem satisfeito nem insatisfeito $7=$ Muito satisfeito

\section{PRIMEIROS CORTES FRESCOS}

1. Costela de porco

2. Paleta, lombo, bisteca

3. Pernil

4. Outros (miúdos, toucinho, rabo, orelha)

FRESCOS E POUCO PROCESSADOS

5.Exemplos: linguiças, espetinho, carne embalada a vácuo, salsichão, carne de porco moída

MAIS PROCESSADOS

6. Exemplo: carne recheada, escalope, carne assada, espetinho, marinados, temperados

REFEIÇOES

7. Exemplo: lasanha, pizza, macarronada, feijoada

PRODUTOS DE CARNE

8.1. Frios (salame, presunto, mortadela)

8.2. Bacon

\begin{tabular}{|l|l|l|}
\hline & 2 \\
\hline 1 & 2 \\
\hline 1 & 2 \\
\hline 1 & 2 \\
\hline
\end{tabular}

\begin{tabular}{l|l|l|}
2 & 3 & \\
2 & 3 & \\
2 & 3 & \\
2 & 3 &
\end{tabular}

\begin{tabular}{|l|l|}
\hline 4 & 5 \\
\hline 4 & 5 \\
\hline 4 & 5 \\
\hline 4 & 5
\end{tabular}

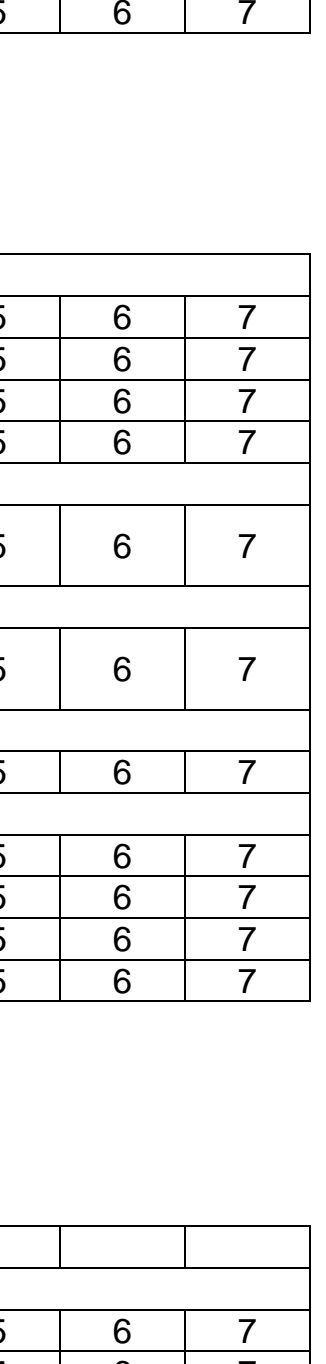

\begin{tabular}{l|l}
5 & 6 \\
\hline 5 & 6 \\
\hline 5 & 6
\end{tabular}

5 6

\begin{tabular}{|l|l|}
\hline 6 & 7 \\
\hline 6 & 7 \\
\hline & 7 \\
\hline
\end{tabular}

\begin{tabular}{|l|l|l|l|l|l|l|}
\hline 1 & 2 & 3 & 4 & 5 & 6 & 7 \\
\hline
\end{tabular}


8.3. Salsichas e linguiças

8.4. Patê

\begin{tabular}{|l|l|l|l|l|l|l|}
1 & 2 & 3 & 4 & 5 & 6 & 7 \\
\hline 1 & 2 & 3 & 4 & 5 & 6 & 7 \\
\hline
\end{tabular}

Q.20 Quanto está satisfeito com a FACILIDADE DE PREPARAR UMA REFEIÇÃO com esse produto? (RU)

Você pode responder com um número de 1 a 7 , em que 1 significa " nem um pouco

satisfeito" e 7 significa "muito satisfeito". Você pode responder com os números intermediários.

1= Nem um pouco satisfeito $4=$ Nem satisfeito nem insatisfeito $7=$ Muito satisfeito

\section{PRIMEIROS CORTES FRESCOS}

1. Costela de porco

2. Paleta, lombo, bisteca

3. Pernil

4. Outros (miúdos, toucinho, rabo, orelha)

FRESCOS E POUCO PROCESSADOS

5.Exemplos: linguiças, espetinho, carne embalada a vácuo, salsichão, carne de porco moída

MAIS PROCESSADOS

6. Exemplo: carne recheada, escalope, carne assada, espetinho, marinados, temperados

REFEIÇOES

7. Exemplo: lasanha, pizza, macarronada, feijoada

PRODUTOS DE CARNE

8.1. Frios (salame, presunto, mortadela)

8.2. Bacon

8.3. Salsichas e linguiças

8.4. Patê

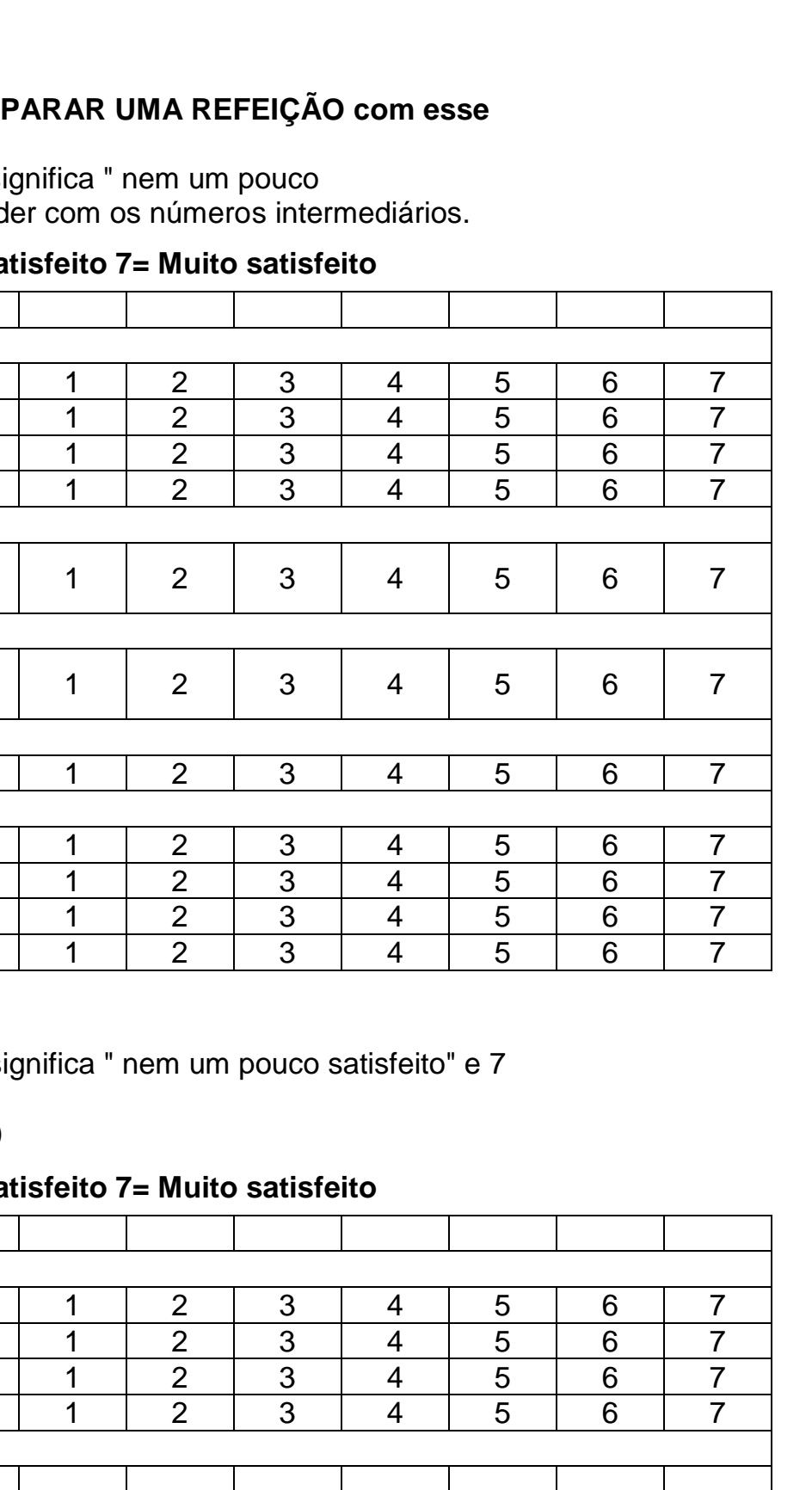

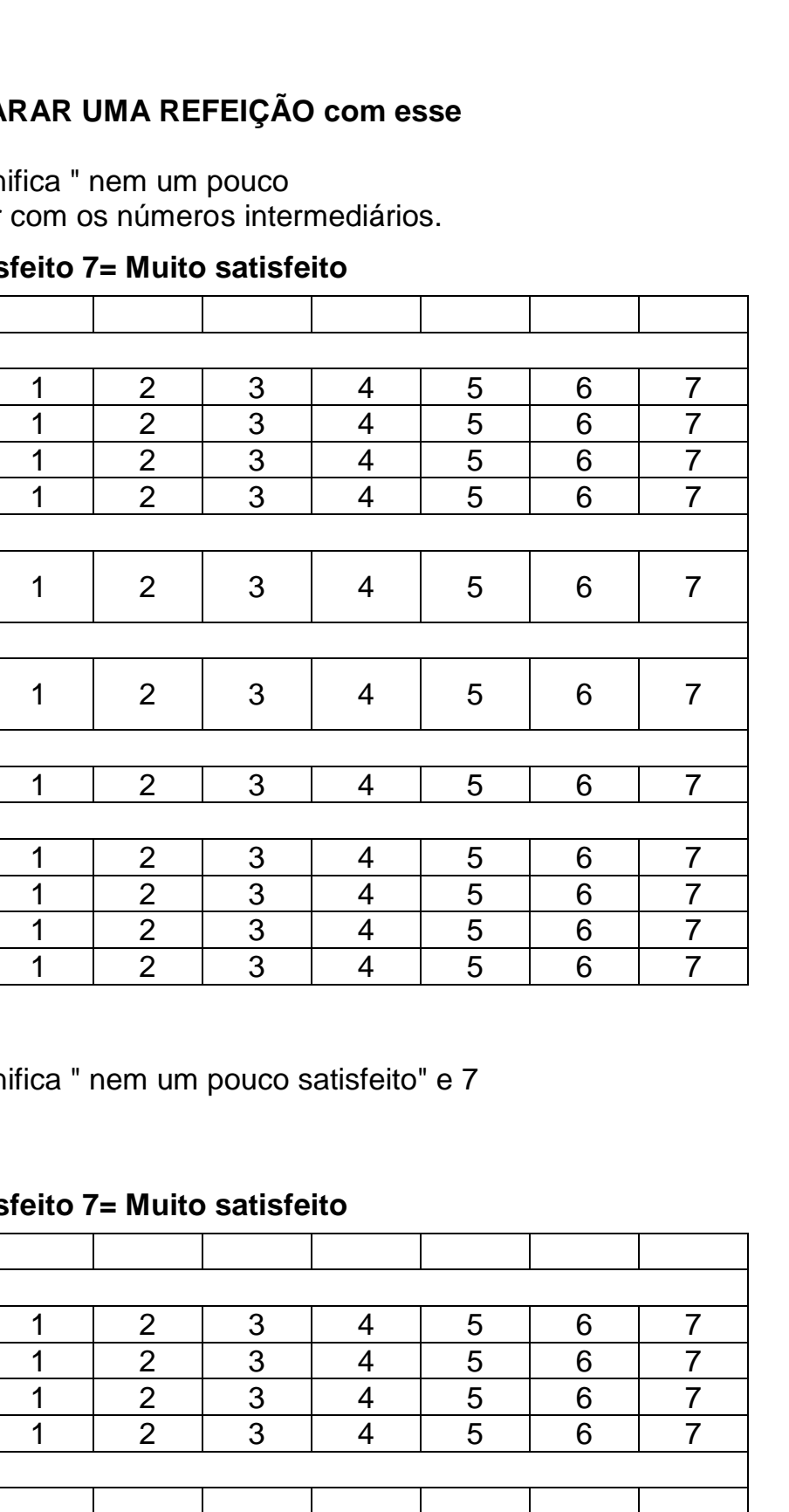

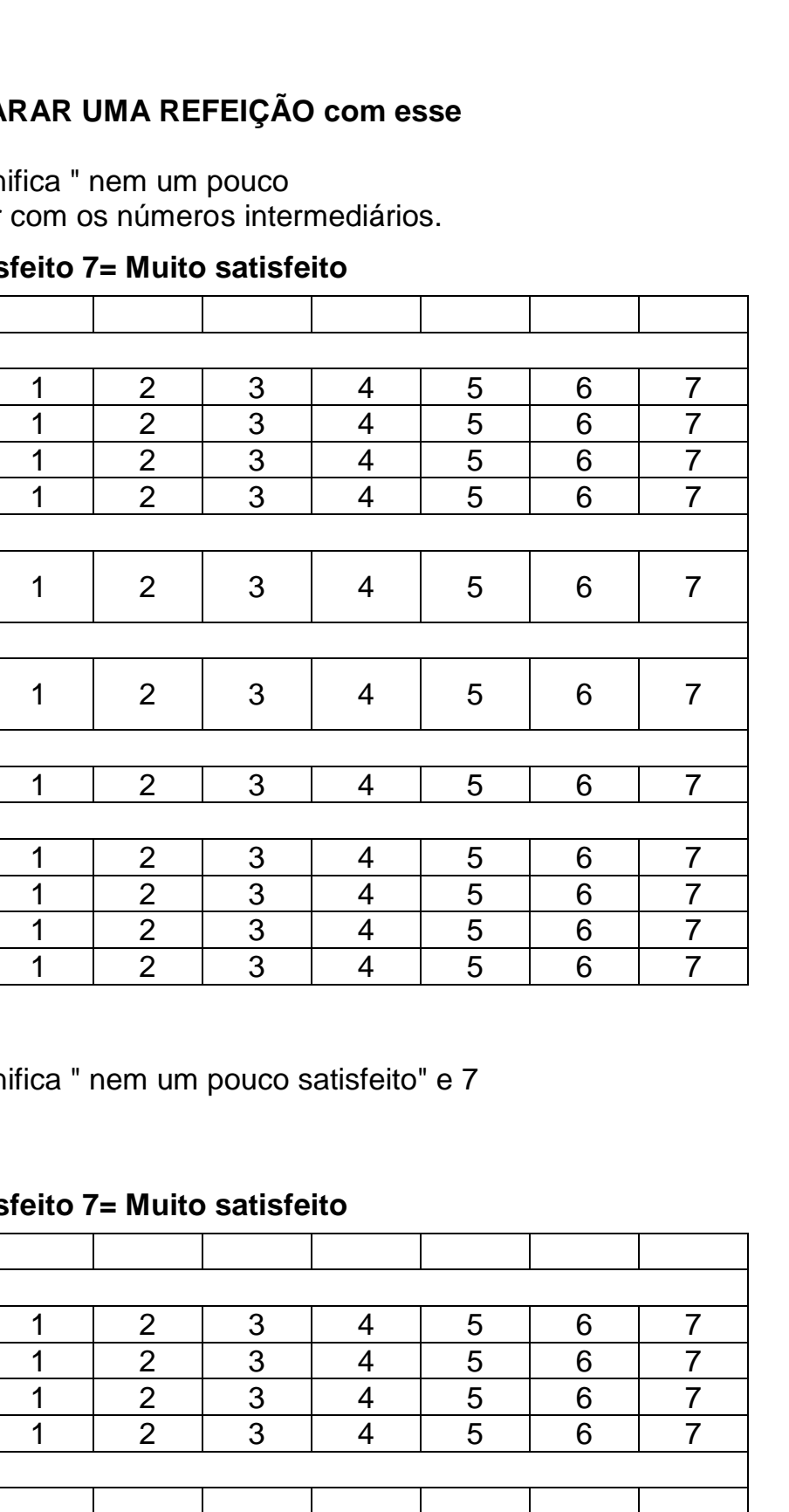

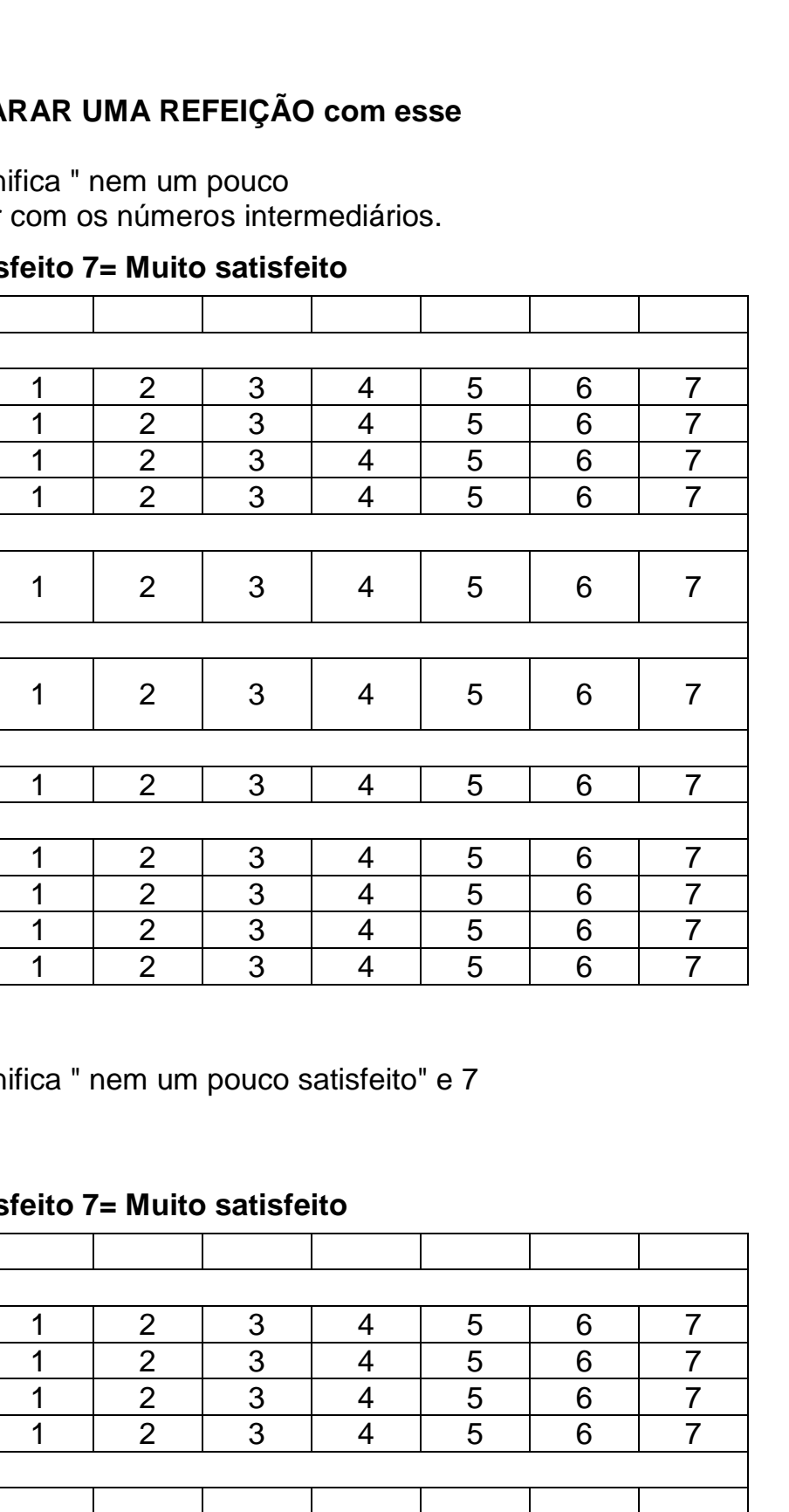

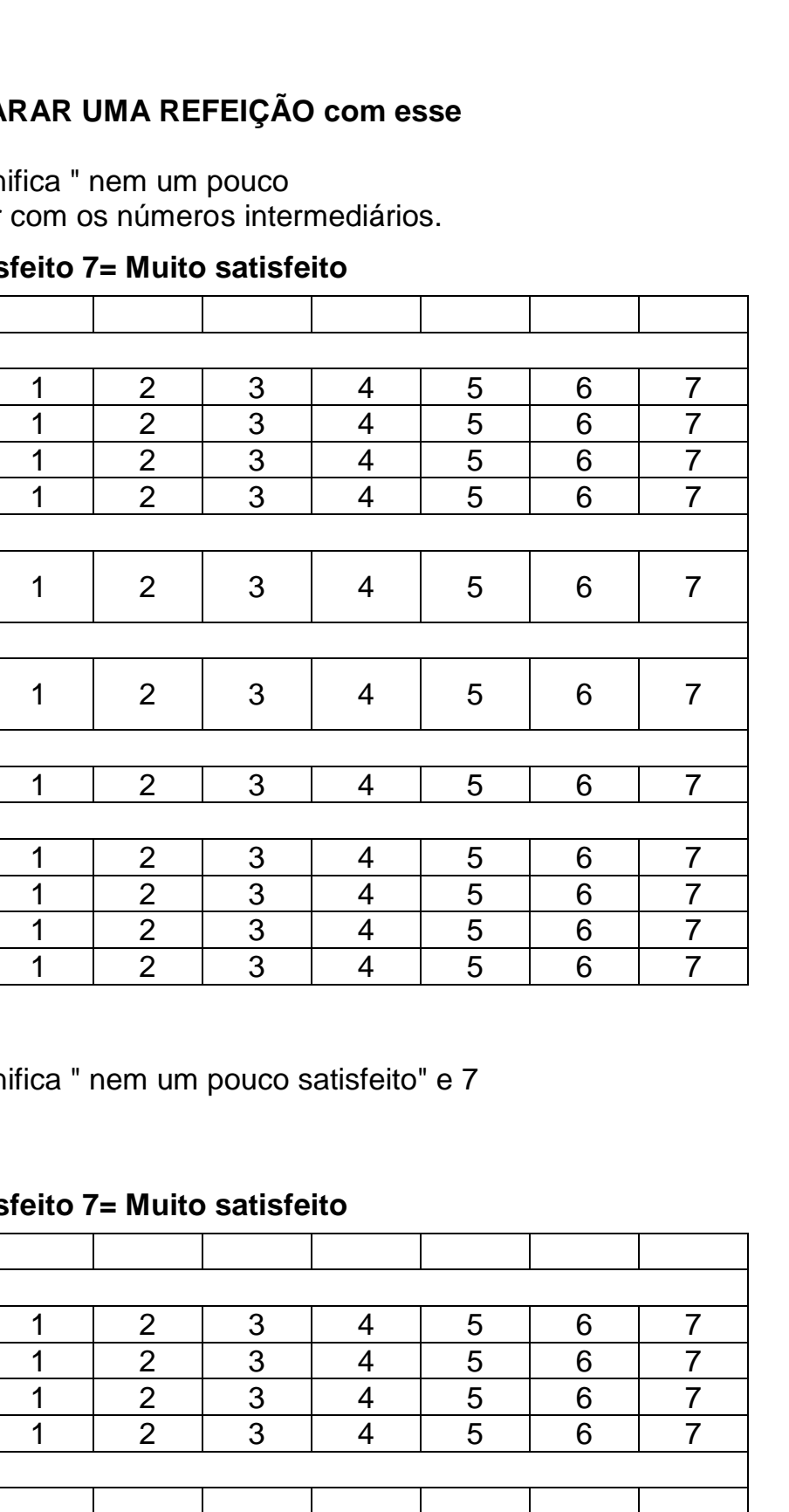

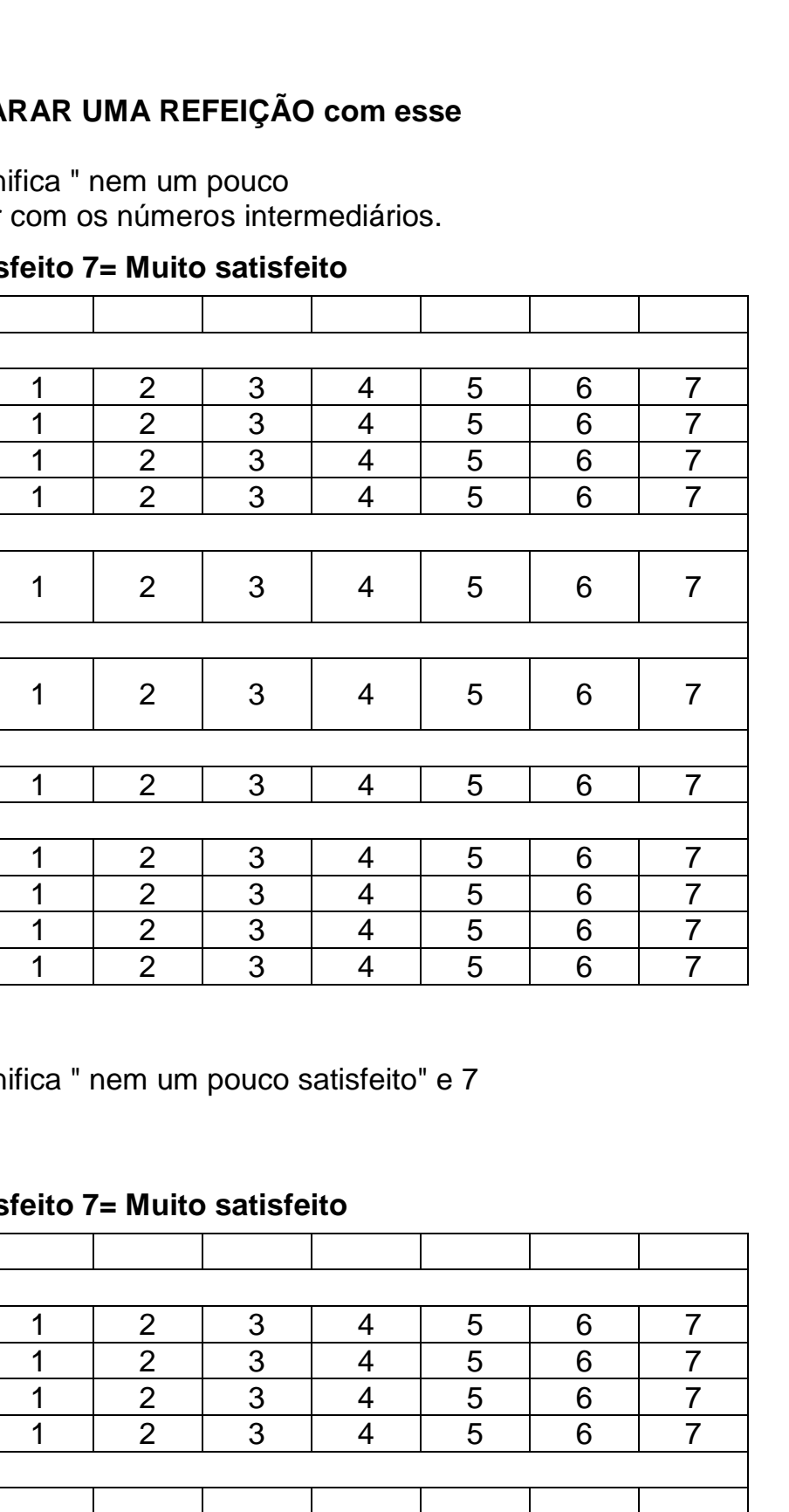

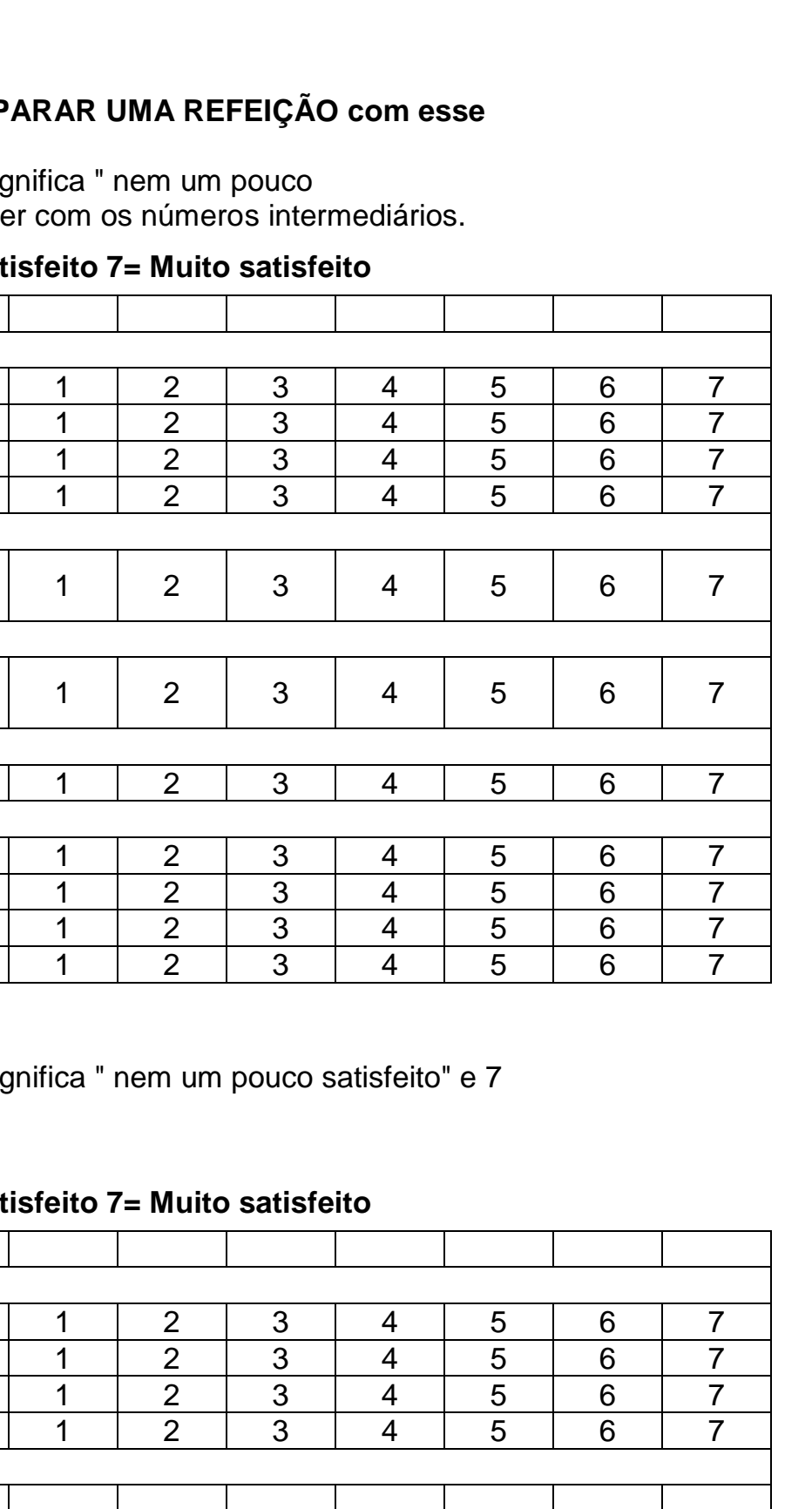

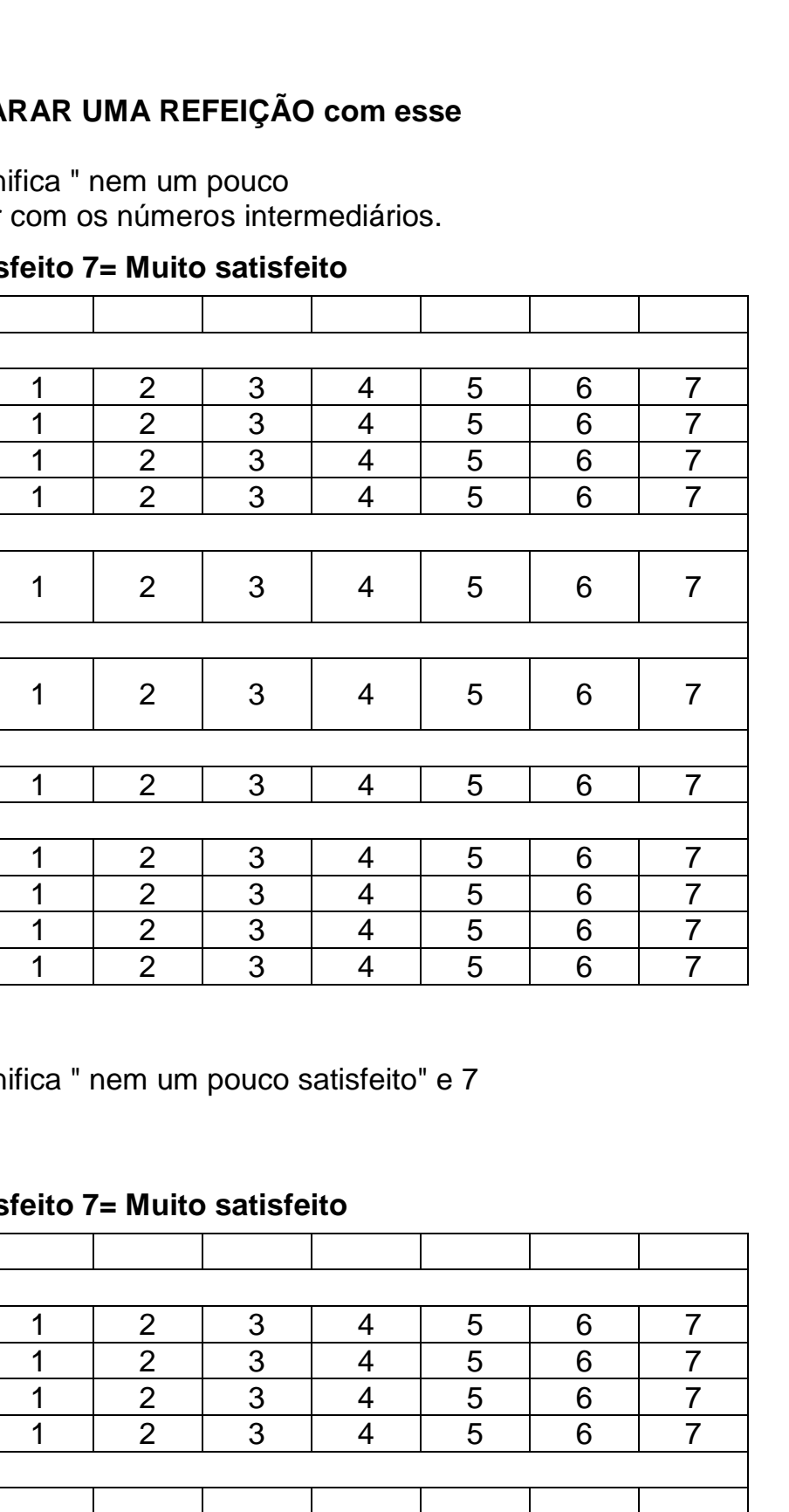

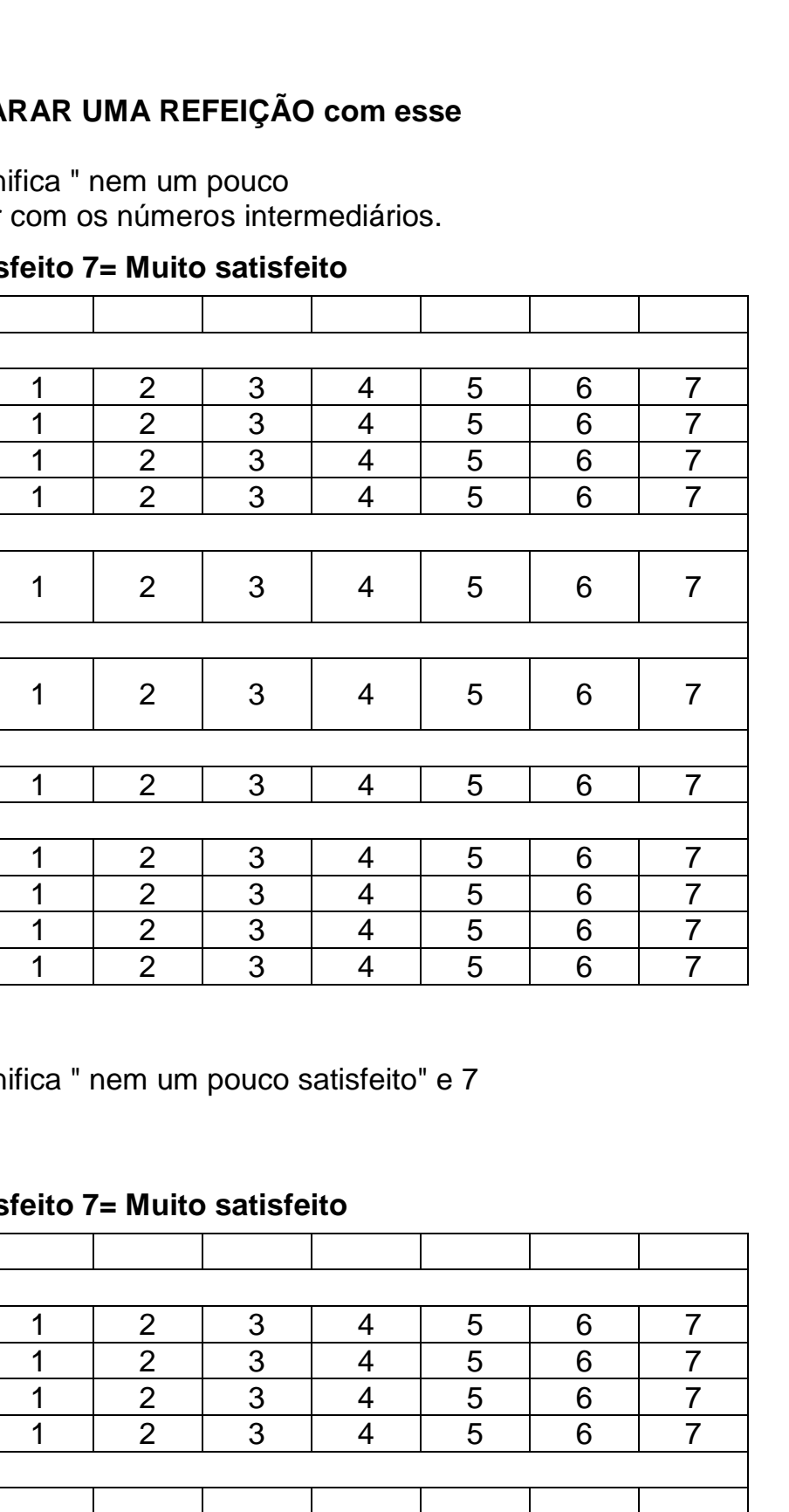

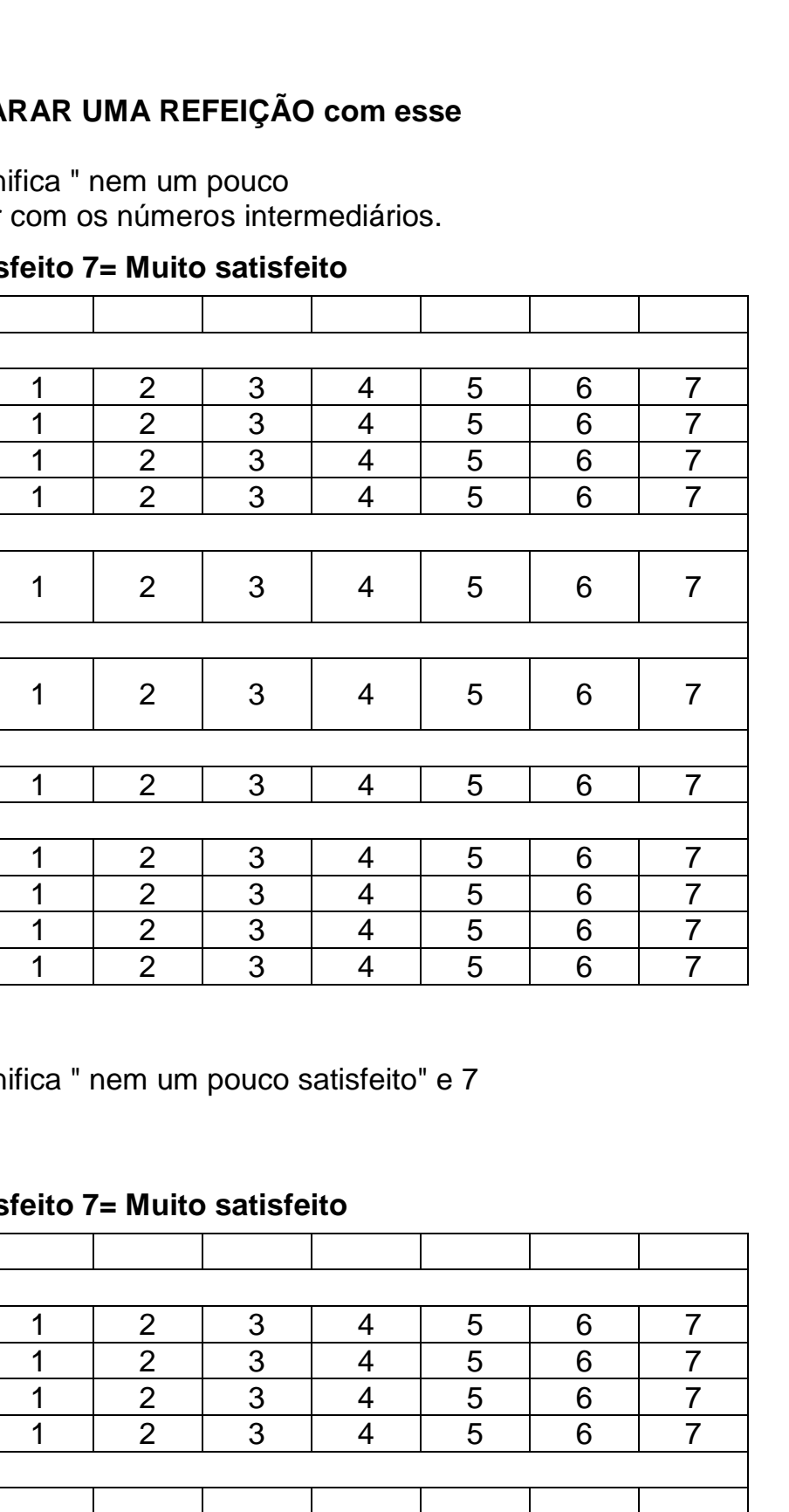

6

7

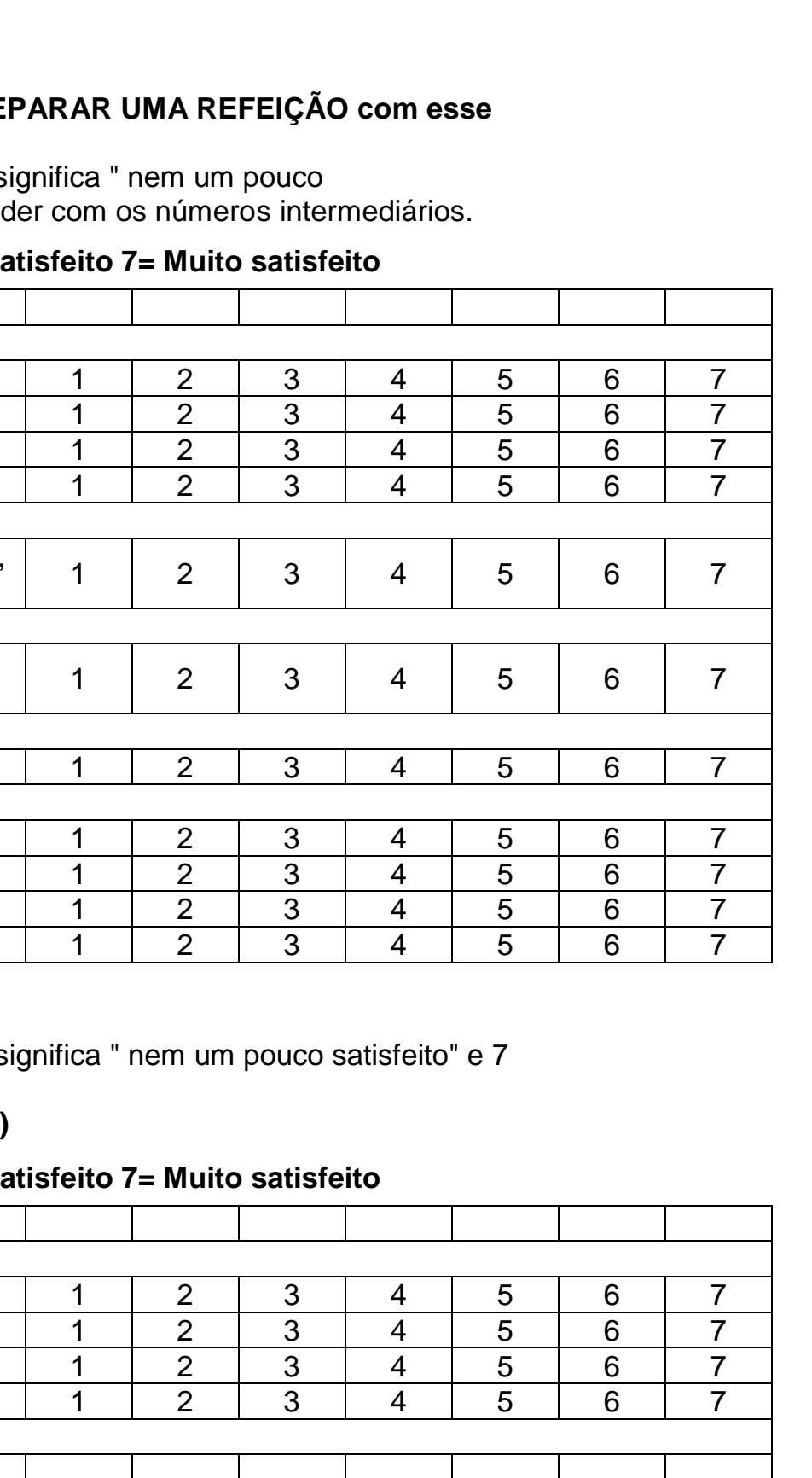

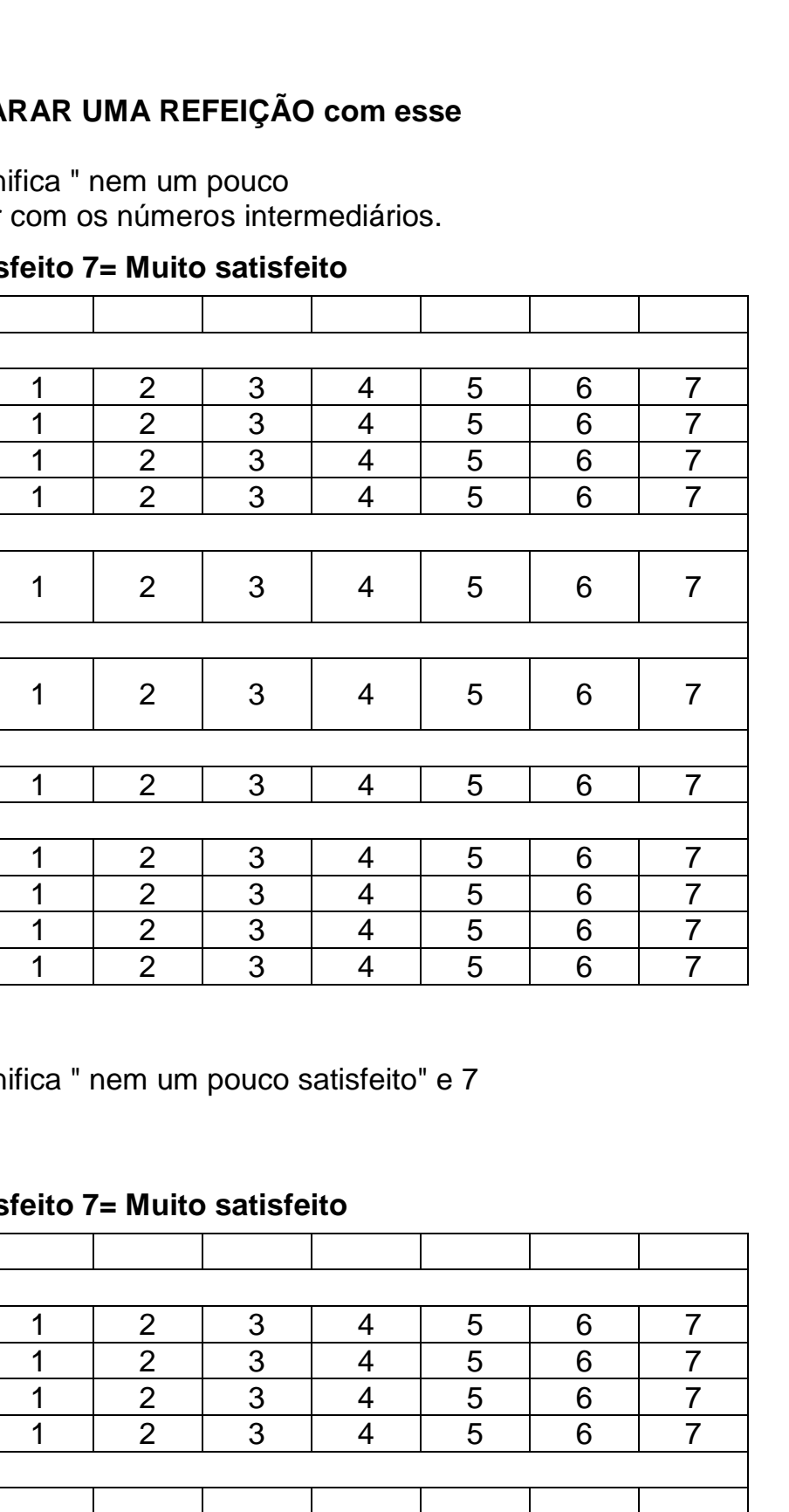

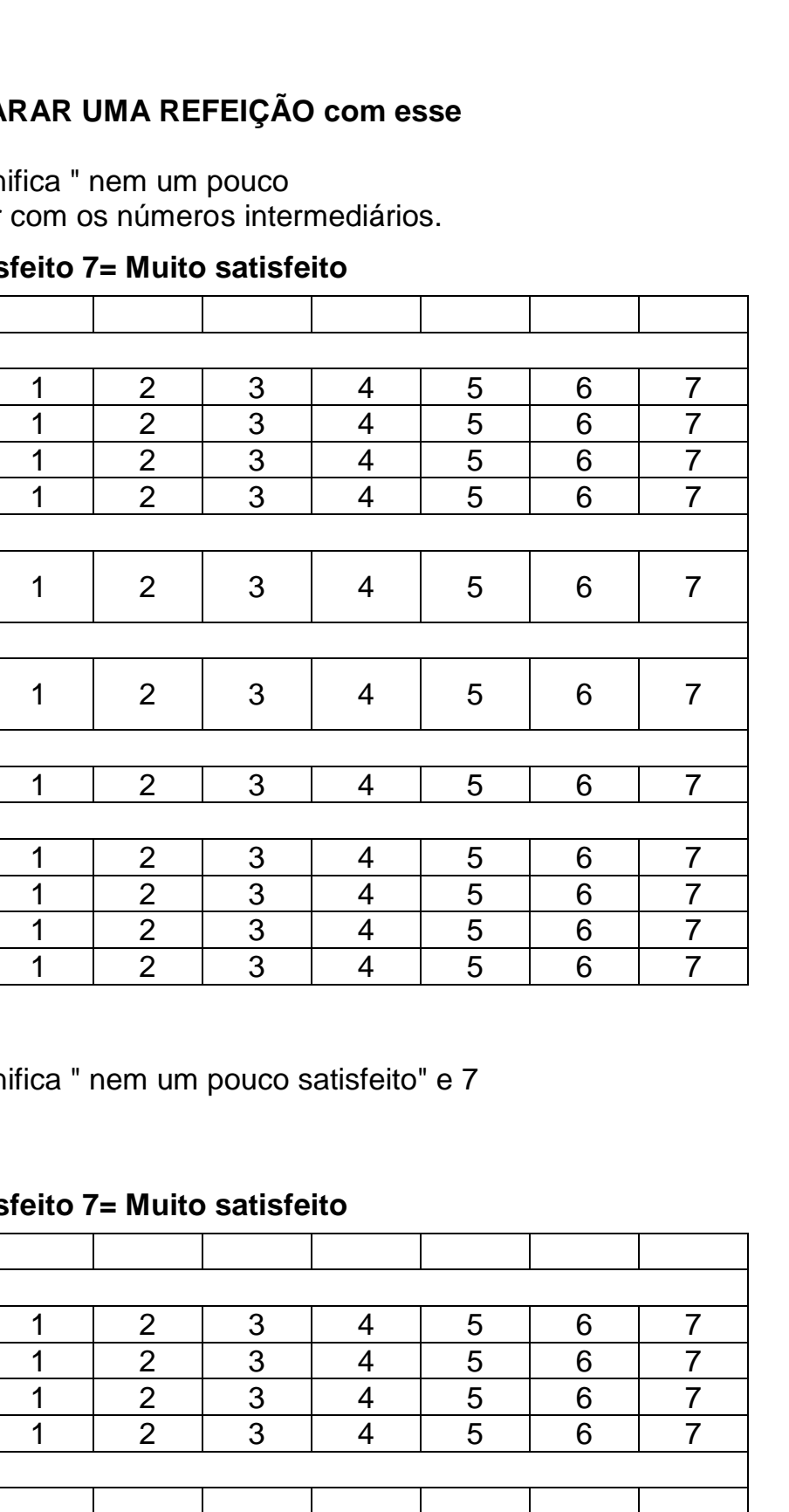

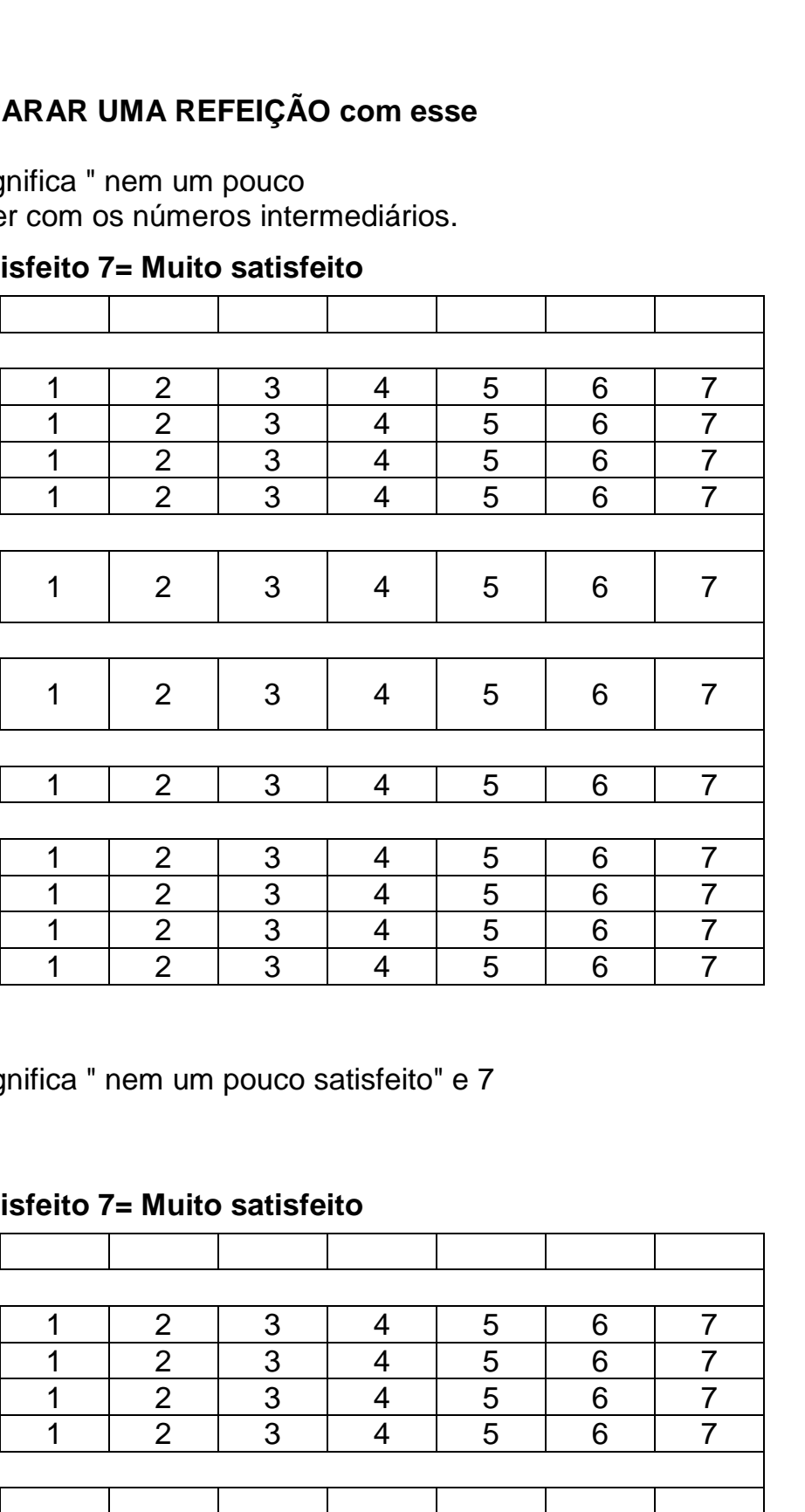

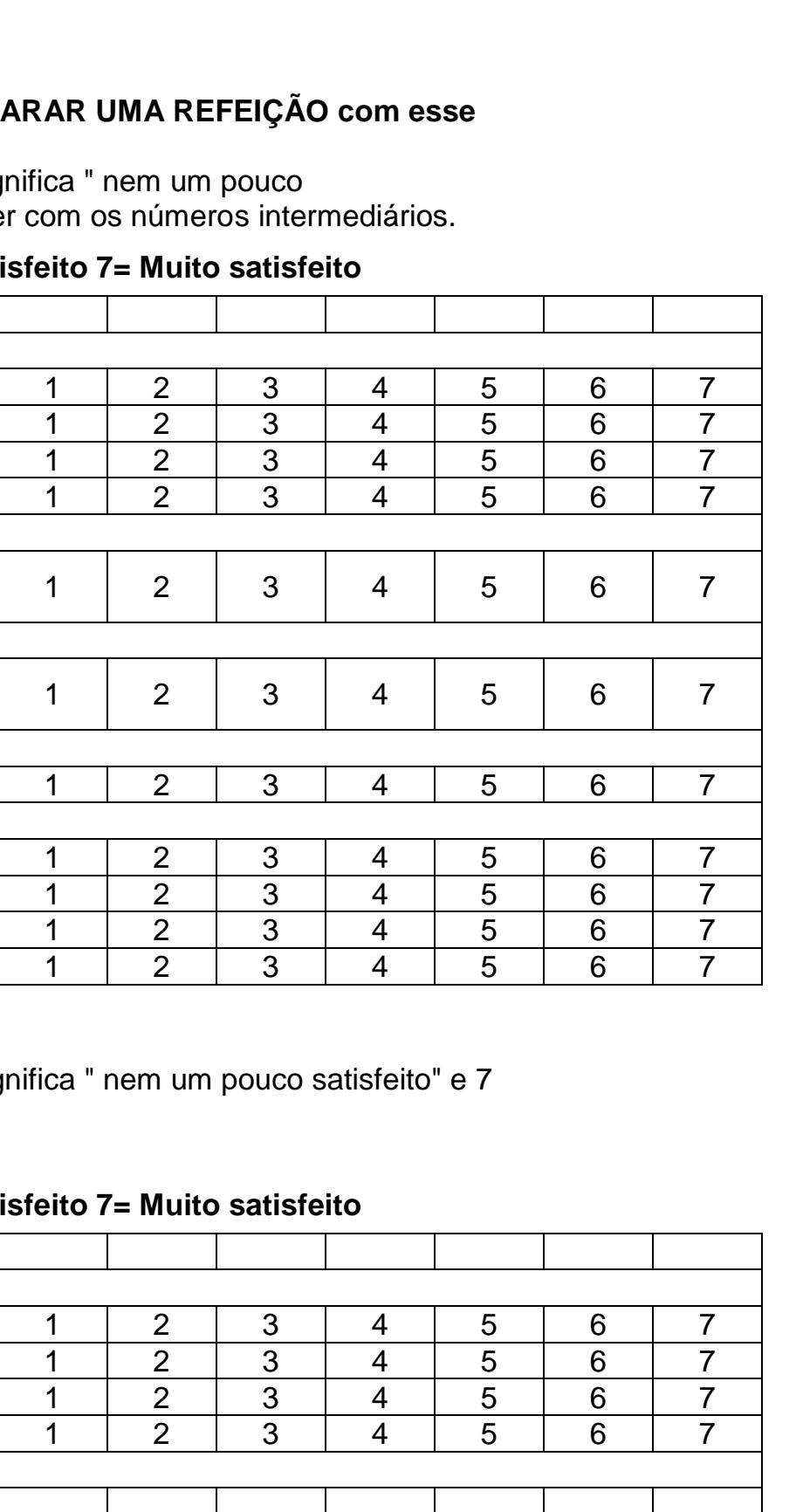

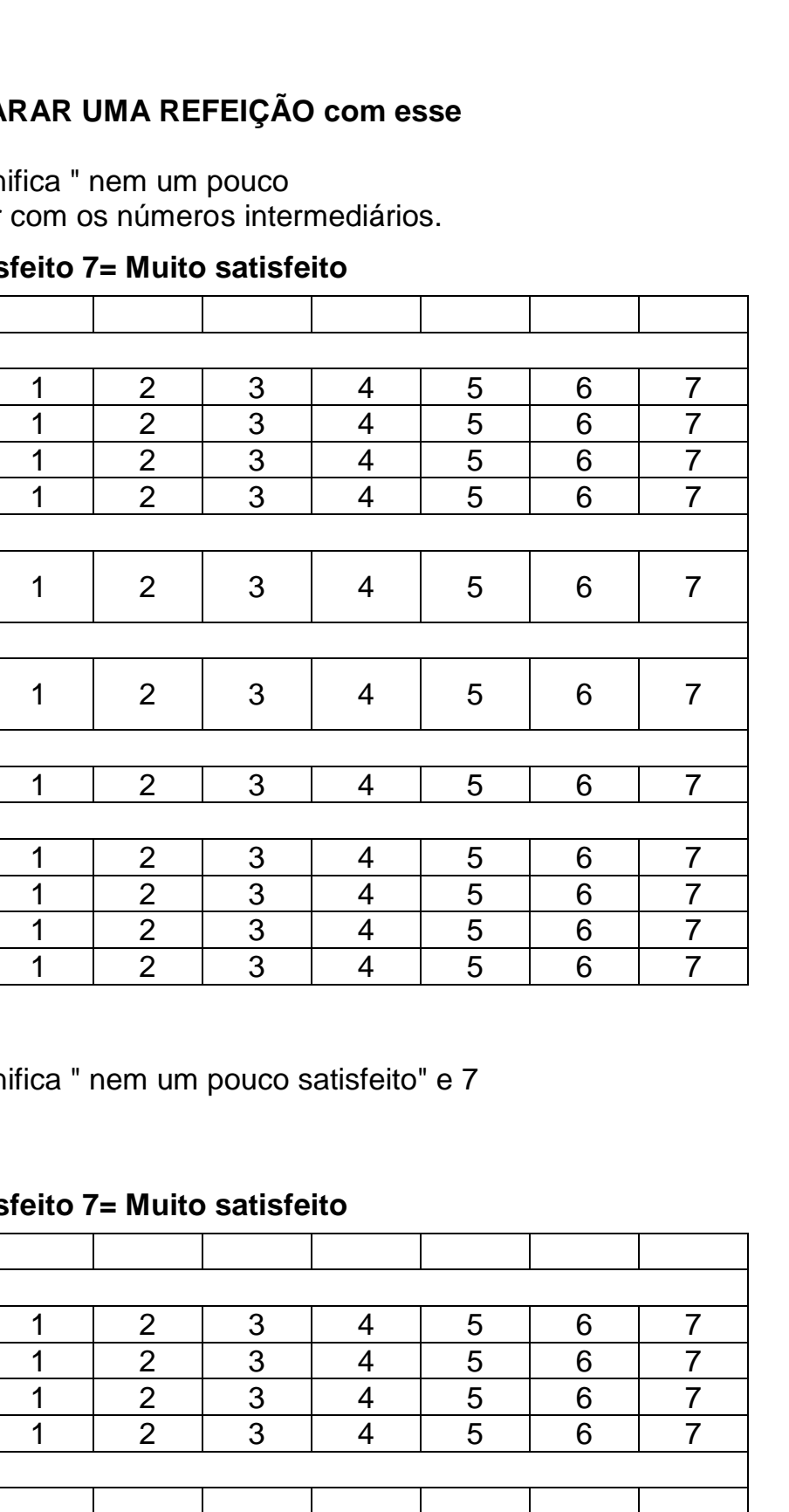

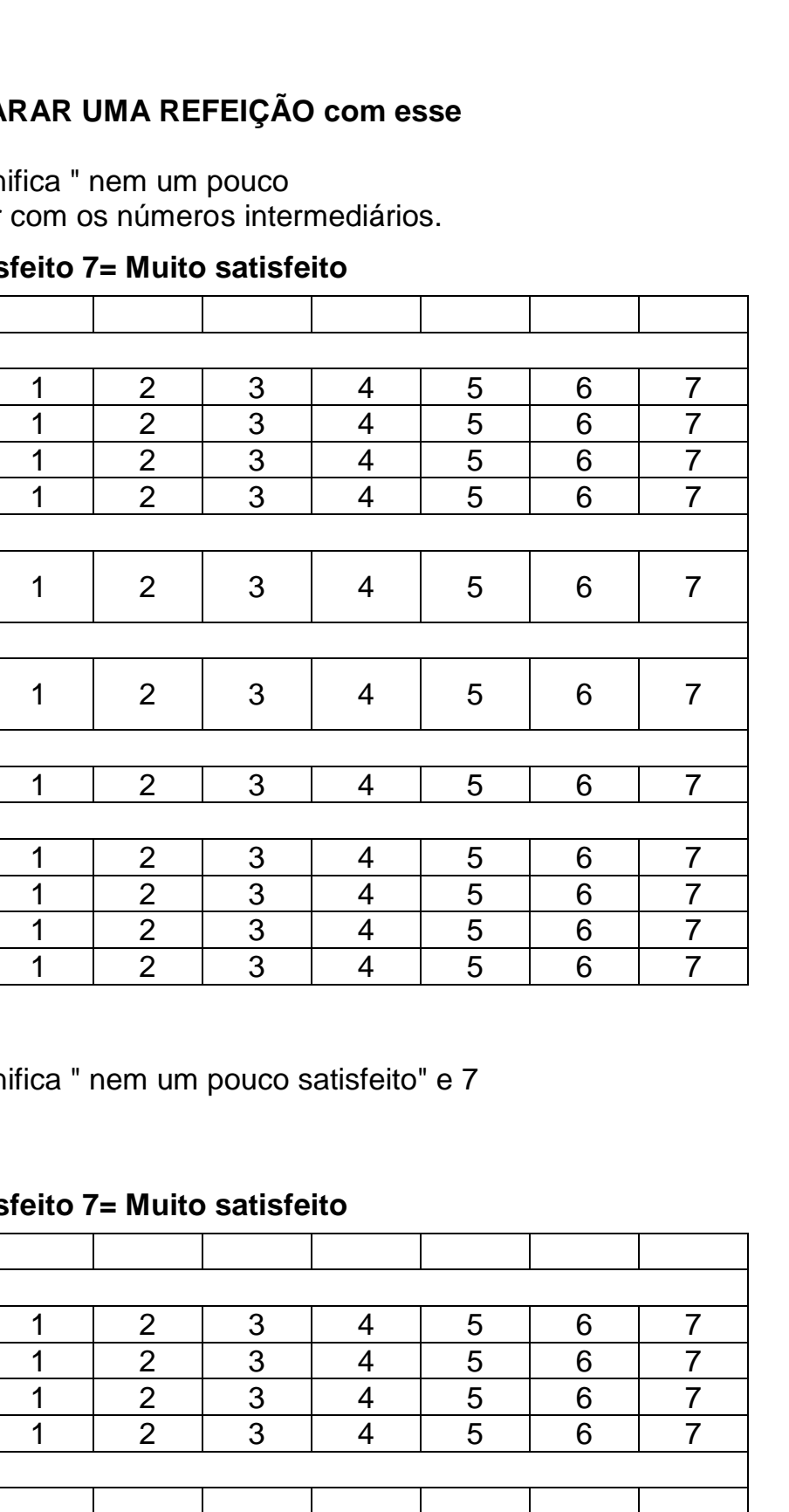

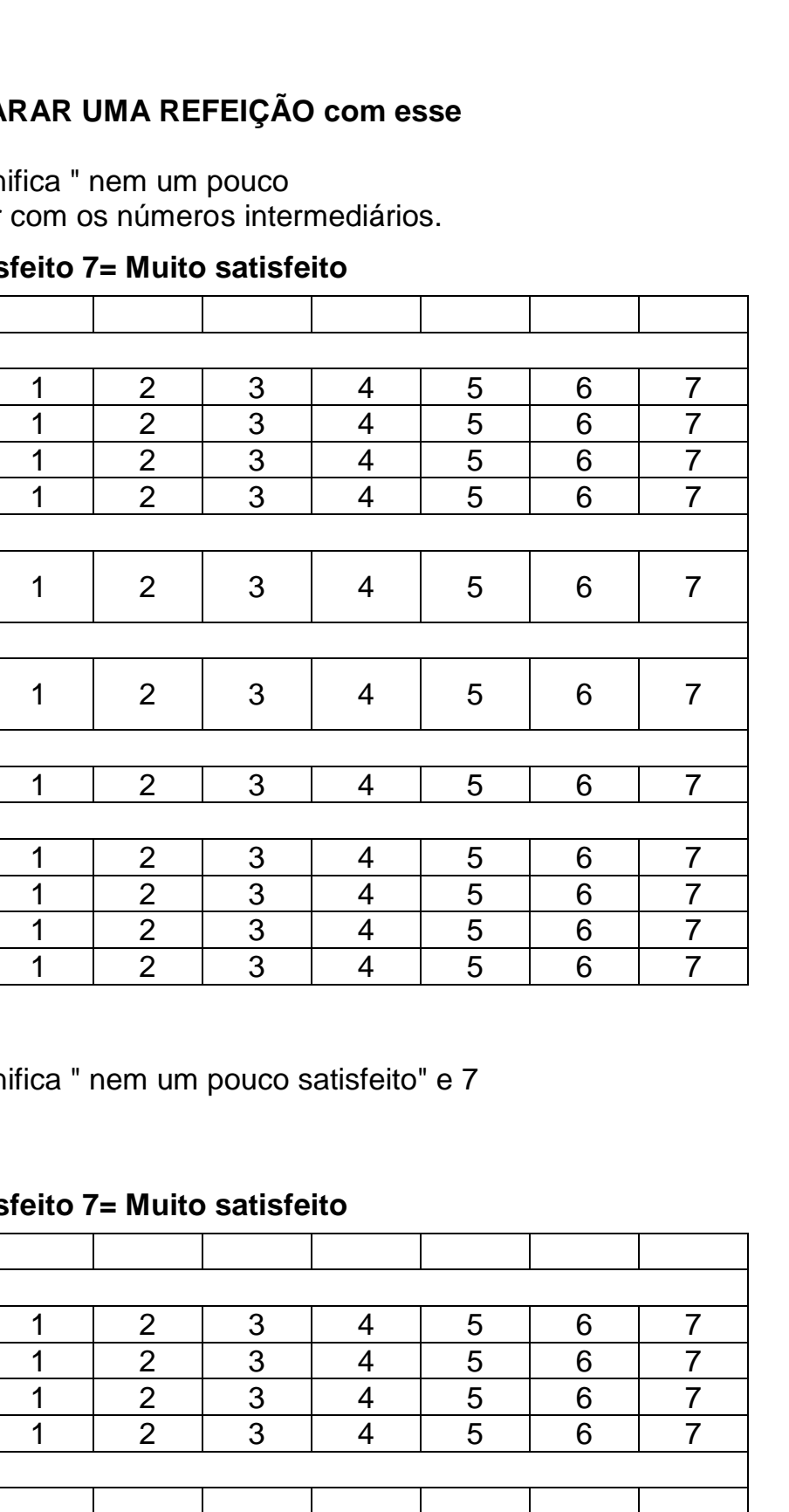

Q21. Quanto está satisfeito com o PREÇO do produto?

Você pode responder com um número de 1 a 7 , em que 1 significa " nem um pouco satisfeito" e 7 significa "muito satisfeito".

Você pode responder com os números intermediários. (RU)

1= Nem um pouco satisfeito $4=$ Nem satisfeito nem insatisfeito $7=$ Muito satisfeito

\section{PRIMEIROS CORTES FRESCOS}

1. Costela de porco

2. Paleta, lombo, bisteca

3. Pernil

4. Outros (miúdos, toucinho, rabo, orelha)

FRESCOS E POUCO PROCESSADOS

5.Exemplos: linguiças, espetinho, carne embalada a vácuo, salsichão, carne de porco moída MAIS PROCESSADOS

6.Exemplo: carne recheada, escalope, carne assada, espetinho, marinados, temperados

REFEIÇOES

7.Exemplo: lasanha, pizza, macarronada, feijoada PRODUTOS DE CARNE

8.1. Frios (salame, presunto, mortadela)

8.2. Bacon

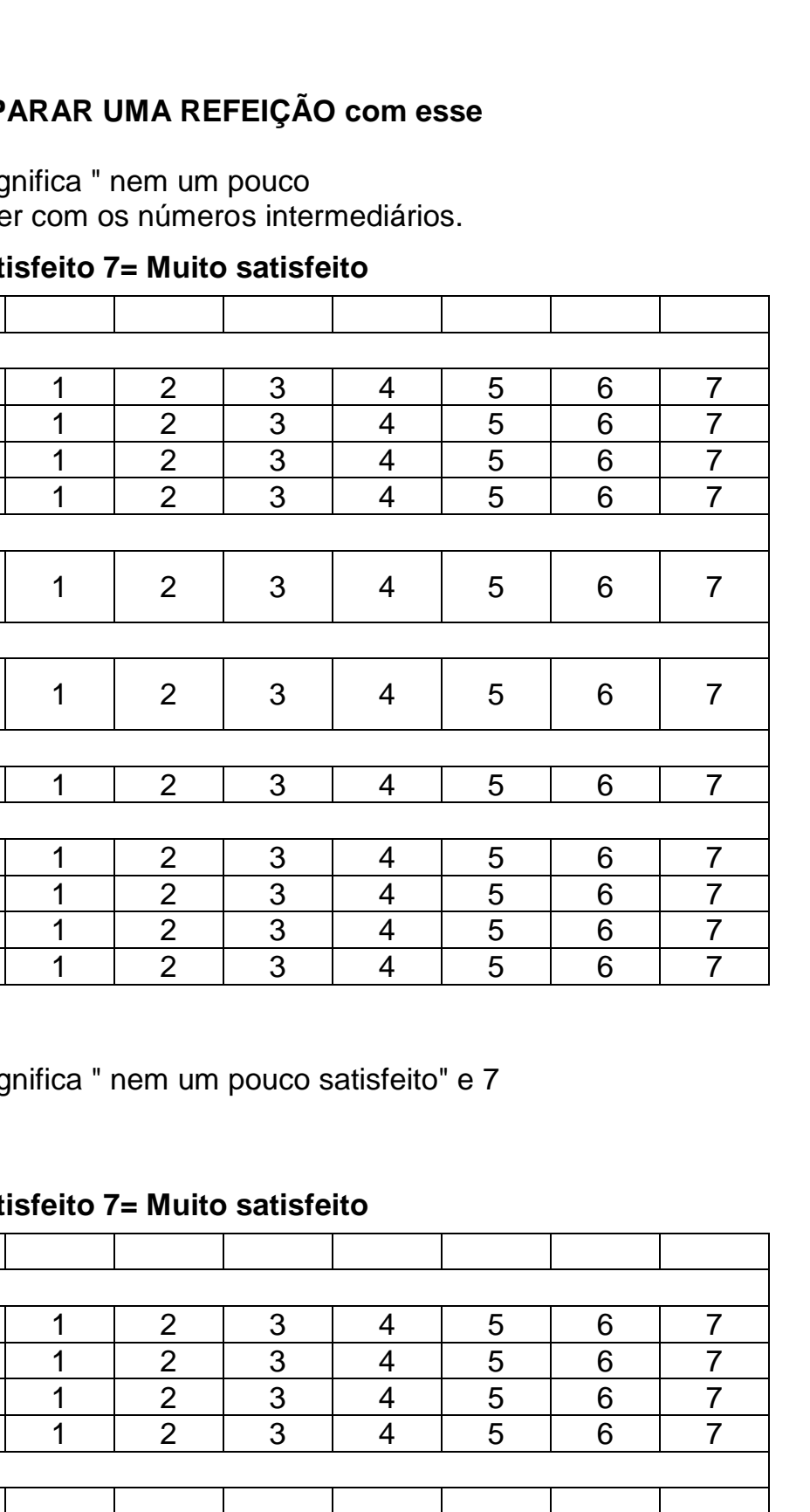

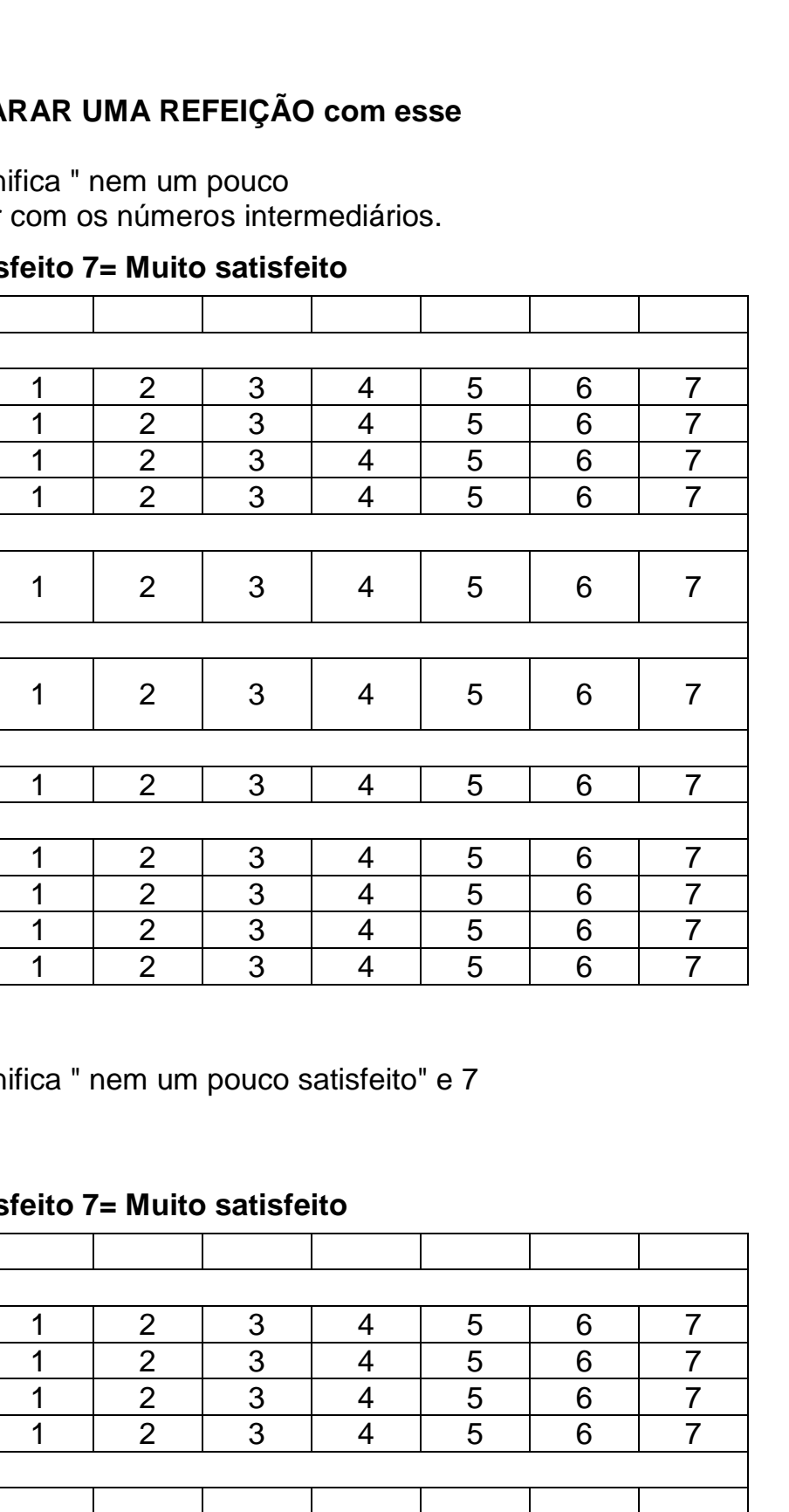

\begin{tabular}{|l|l|l|l|l|l|l|}
\hline 1 & 2 & 3 & 4 & 5 & 6 & 7 \\
\hline
\end{tabular}

\begin{tabular}{|l|l|l|l|l|l|l|}
\hline 1 & 2 & 3 & 4 & 5 & 6 & 7 \\
\hline
\end{tabular}

\begin{tabular}{|l|l|l|l|l|l|l|}
\hline 1 & 2 & 3 & 4 & 5 & 6 & 7 \\
\hline
\end{tabular}


8.3. Salsichas e linguiças

8.4. Patê

\begin{tabular}{l|l}
1 & 2 \\
1 & 2 \\
\hline
\end{tabular}

\begin{tabular}{l|l|}
\hline 2 & 3 \\
\hline 2 & 3 \\
\hline
\end{tabular}

4

\begin{tabular}{l|l}
4 & 5 \\
\hline 4 & 5
\end{tabular}

5

\begin{tabular}{|l|l|}
\hline 6 & 7 \\
\hline 6 & 7 \\
\hline
\end{tabular}

Q22. Com quais dos produtos que vou ler, você costuma combinar os tipos de carne de porco em uma refeição? (RM) PERGUNTE SÓ P/ OS PRODUTOS QUE RECEBERAM CÓDIGO 3 a 8 NA QUESTÃO 10)

\begin{tabular}{|c|c|c|c|c|c|c|c|c|c|c|c|c|c|c|}
\hline & \multicolumn{5}{|c|}{ Guarnições } & \multicolumn{3}{|c|}{ Vegetais } & \multirow[b]{2}{*}{$\frac{\frac{9 .}{\text { Acom }}}{\frac{\text { panh }}{\text { amen }}}$} & \multicolumn{5}{|c|}{ Bebidas } \\
\hline & $\begin{array}{c}1 . \\
\text { Arroz }\end{array}$ & $\begin{array}{l}\text { 2. Ba } \\
\text { tata }\end{array}$ & $\begin{array}{c}3 . \\
\text { Sala } \\
\text { da }\end{array}$ & $\begin{array}{l}\text { 4. Ma } \\
\text { ssa }\end{array}$ & $\begin{array}{l}5 . \\
\text { Feijão }\end{array}$ & $\begin{array}{l}\text { 6.Ba } \\
\text { tata } \\
\text { doce }\end{array}$ & $\begin{array}{c}7 . \\
\text { Mandi } \\
\text { oca }\end{array}$ & $\begin{array}{l}\text { 8. Ve- } \\
\text { getais }\end{array}$ & & $\begin{array}{l}10 . \\
\text { Água }\end{array}$ & $\begin{array}{c}11 . \\
\text { Bebi } \\
\text { da } \\
\text { gela } \\
\text { da } \\
\end{array}$ & $\begin{array}{l}12 . \\
\text { Bebi } \\
\text { da } \\
\text { quen } \\
\text { te } \\
\end{array}$ & $\begin{array}{l}13 . \\
\text { Alcoó } \\
\text { licas }\end{array}$ & $\begin{array}{c}14 . \\
\text { Ou } \\
\text { tros }\end{array}$ \\
\hline \multicolumn{15}{|c|}{ PRIMEIROS CORTES FRESCOS } \\
\hline $\begin{array}{l}\text { 1. Costela de } \\
\text { porco }\end{array}$ & 1 & 2 & 3 & 4 & 5 & 6 & 7 & 8 & 9 & 10 & 11 & 12 & 13 & 14 \\
\hline $\begin{array}{l}\text { 2. Paleta, } \\
\text { lombo, bisteca }\end{array}$ & 1 & 2 & 3 & 4 & 5 & 6 & 7 & 8 & 9 & 10 & 11 & 12 & 13 & 14 \\
\hline 3. Pernil & 1 & 2 & 3 & 4 & 5 & 6 & 7 & 8 & 9 & 10 & 11 & 12 & 13 & 14 \\
\hline $\begin{array}{l}\text { 4. Outros } \\
\text { (miúdos, } \\
\text { toucinho, rabo, } \\
\text { orelha) }\end{array}$ & 1 & 2 & 3 & 4 & 5 & 6 & 7 & 8 & 9 & 10 & 11 & 12 & 13 & 14 \\
\hline \multicolumn{15}{|c|}{ FRESCOS E POUCO PROCESSADOS } \\
\hline $\begin{array}{l}\text { 5. Exemplos: } \\
\text { linguiças, } \\
\text { salsichão, } \\
\text { carne } \\
\text { embalada a } \\
\text { vácuo, carne } \\
\text { de porco } \\
\text { moída }\end{array}$ & 1 & 2 & 3 & 4 & 5 & 6 & 7 & 8 & 9 & 10 & 11 & 12 & 13 & 14 \\
\hline \multicolumn{15}{|c|}{ MAIS PROCESSADOS } \\
\hline $\begin{array}{l}\text { 6.Exemplo: } \\
\text { carne } \\
\text { recheada, } \\
\text { escalope, } \\
\text { carne assada, } \\
\text { espetinho }\end{array}$ & 1 & 2 & 3 & 4 & 5 & 6 & 7 & 8 & 9 & 10 & 11 & 12 & 13 & 14 \\
\hline \multicolumn{15}{|l|}{ REFEIÇÕES } \\
\hline $\begin{array}{l}\text { 7. Exemplo: } \\
\text { lasanha, } \\
\text { pizza, } \\
\text { macarronada, } \\
\text { feijoada }\end{array}$ & 1 & 2 & 3 & 4 & 5 & 6 & 7 & 8 & 9 & 10 & 11 & 12 & 13 & 14 \\
\hline \multicolumn{15}{|c|}{ PRODUTOS DE CARNE } \\
\hline $\begin{array}{l}\text { 8.1. Frios } \\
\text { (salame, } \\
\text { presunto, } \\
\text { mortadela) }\end{array}$ & 1 & 2 & 3 & 4 & 5 & 6 & 7 & 8 & 9 & 10 & 11 & 12 & 13 & 14 \\
\hline
\end{tabular}




\begin{tabular}{|l|c|c|c|c|c|c|c|c|c|c|c|c|c|c|}
\hline 8.2. Bacon & 1 & 2 & 3 & 4 & 5 & 6 & 7 & 8 & 9 & 10 & 11 & 12 & 13 & 14 \\
\hline $\begin{array}{l}\text { 8.3. Salsichas } \\
\text { e linguiças }\end{array}$ & 1 & 2 & 3 & 4 & 5 & 6 & 7 & 8 & 9 & 10 & 11 & 12 & 13 & 14 \\
\hline 8.4. Patê & 1 & 2 & 3 & 4 & 5 & 6 & 7 & 8 & 9 & 10 & 11 & 12 & 13 & 14 \\
\hline
\end{tabular}

Descrição das categorias:

Guarnições: Arroz, Batata, Salada, Massa, feijão (podendo ser carioquinha marronzinho ou preto)

Vegetais:Batata-doce, Mandioca, Vegetais variados (cenoura, tomate, cebola, brócolis, ervilha)

Acompanhamentos descreva como exemplos: condimentos, molhos, conservas, geleias

Bebidas: Água, bebidas geladas (refrigerantes, sucos),Bebidas quentes (café, chá, cappuccino), Alcoólicas (vinho, cerveja, destilados), Outros 


\section{APÊNDICE B}

Estudos em Marketing com base no projeto Q-PorkChains

\begin{tabular}{|c|c|c|}
\hline Autor(es)/Ano/Publicaçã & Objetivos/Método & Principais resultados \\
\hline $\begin{array}{l}\text { Verbeke et al (2008), } Q- \\
\text { PorkChains } \\
\text { interno). }\end{array}$ & $\begin{array}{l}\text { Trabalho desenvolvido dentro do } \\
\text { Projeto Integrado Q-PorkChains, em } \\
\text { que se aplicou-se uma pesquisa em } \\
\text { cinco países europeus selecionados, } \\
\text { mais China e Brasil. Este relatório } \\
\text { expõe as conclusões da pesquisa nos } \\
\text { países europeus. Foram aplicados pela } \\
\text { internet } 480 \text { questionários em cada um } \\
\text { dos países, em média, perfazendo um } \\
\text { total de } 2.437 \text { questionários } \\
\text { completados. O questionário } \\
\text { compreendia nove seções. }\end{array}$ & $\begin{array}{l}\text { Os resultados mostraram que a penetração } \\
\text { dos produtos é alta, excetuando-se os } \\
\text { miúdos e carne enlatada, que tiveram nível } \\
\text { de penetração abaixo de } 60 \% \text {. Como } \\
\text { esperado, quanto menor o grau de } \\
\text { processamento dos produtos, mais eles } \\
\text { tendem a ser preparados em casa desde o } \\
\text { início. Pessoas de locais com maiores níveis } \\
\text { de produção consomem mais produtos } \\
\text { minimamente processados, enquanto pratos } \\
\text { à base de carne suína são mais consumidos } \\
\text { em áreas urbanas. Encontrou-se uma } \\
\text { tendência crescente de consumo em relação } \\
\text { à situação financeira dos respondentes, e os } \\
\text { consumidores estão em geral satisfeitos com } \\
\text { os produtos e um pouco menos com o preço } \\
\text { e com as características saudáveis dos } \\
\text { produtos. }\end{array}$ \\
\hline $\begin{array}{l}\text { Neves et al (2008), } Q- \\
\text { PorkChains } \\
\text { interno). }\end{array}$ & $\begin{array}{l}\text { Este trabalho foi desenvolvido como } \\
\text { parte do Projeto Integrado Q- } \\
\text { PorkChains, no qual foi aplicada uma } \\
\text { pesquisa em cinco países europeus } \\
\text { mais Brasil e China. O objetivo da } \\
\text { pesquisa era avaliar a maneira e a } \\
\text { frequência com que a carne suína entra } \\
\text { no padrão de consumo das pessoas. No } \\
\text { Brasil, aplicou-se um extenso } \\
\text { questionário por meio de entrevista } \\
\text { pessoal a } 482 \text { respondentes; embora o } \\
\text { questionário compreenda várias partes } \\
\text { incluindo atitudes em relação à } \\
\text { natureza, meio ambiente, maneiras } \\
\text { pelas quais a produção de suínos afeta } \\
\text { a natureza, entre outras, neste } \\
\text { documento são analisadas somente as } \\
\text { partes referentes a frequência de } \\
\text { consumo. }\end{array}$ & $\begin{array}{l}\text { Os resultados no Brasil mostraram que o } \\
\text { consumo de carne suína e produtos } \\
\text { derivados ainda é bastante baixo no país, } \\
\text { apesar de terem boa penetração. Os } \\
\text { brasileiros compram o produto mais em } \\
\text { supermercados que em açougues, e mais } \\
\text { frescos que congelados. De maneira geral, } \\
\text { quanto menos processados, mais os } \\
\text { produtos são comprados para serem } \\
\text { preparados e consumidos em casa. Os } \\
\text { produtos frescos e os pratos à base de carne } \\
\text { suína são mais consumidos nos finais de } \\
\text { semana, e os únicos que são consumidos } \\
\text { com maior frequência são os } \\
\text { frios/embutidos. Os consumidores } \\
\text { brasileiros estão satisfeitos com o produto } \\
\text { de maneira geral, e menos satisfeitos com o } \\
\text { preço e com as características saudáveis do } \\
\text { produto. }\end{array}$ \\
\hline $\begin{array}{l}\text { Krystallis et al (2009), } \\
\text { Livestock Science. }\end{array}$ & $\begin{array}{l}\text { O estudo foi realizado em quatro países } \\
\text { europeus com consumo per capita de } \\
\text { carne suína acima da média (Bélgica, } \\
\text { Dinamarca, Polônia e Alemanha) com } \\
\text { o objetivo de mapear as atitudes dos } \\
\text { cidadãos em relação a sistemas de } \\
\text { produção de suínos e investigar se } \\
\text { essas atitudes possuem alguma relação } \\
\text { com suínos e consumo de carne suína. }\end{array}$ & $\begin{array}{l}\text { Descobriu-se que a relação investigada é } \\
\text { fraca. Assim, a influência do que as pessoas } \\
\text { pensam em seu papel como cidadãos frente } \\
\text { à produção de suínos não parece ser } \\
\text { significante quanto a suas escolhas de } \\
\text { consumo de carne suína. }\end{array}$ \\
\hline $\begin{array}{l}\text { Barcellos et al (2009), } \\
I P C \text {. }\end{array}$ & $\begin{array}{l}\text { O objetivo do estudo foi mapear as } \\
\text { atitudes do cidadão brasileiro em } \\
\text { relação aos sistemas de produção de }\end{array}$ & $\begin{array}{l}\text { Os resultados mostraram que os } \\
\text { respondentes preferem fazendas pequenas e } \\
\text { produção de carne com gordura saudável. }\end{array}$ \\
\hline
\end{tabular}




\begin{tabular}{|c|c|c|}
\hline & $\begin{array}{l}\text { suínos e investigar se essas atitudes } \\
\text { têm alguma associação com o consumo } \\
\text { de carne suína e produtos à base de } \\
\text { carne suína. Além disto, buscou-se } \\
\text { comparar os resultados do Brasil com } \\
\text { um estudo maior, parte de um projeto } \\
\text { internacional, o Q-PorkChains. Os } \\
\text { dados foram coletados por meio de } \\
\text { entrevistas pessoais feitas por uma } \\
\text { empresa profissional de pesquisa com } \\
\text { consumidores de oito cidades } \\
\text { brasileiras. }\end{array}$ & $\begin{array}{l}\text { Encontraram-se três clusters: um cluster } \\
\text { grande, com } 71,6 \% \text { da amostra, não é muito } \\
\text { familiar com sistemas de produção de } \\
\text { suínos e então são definidos como "cidadãos } \\
\text { medianos"; o outro cluster, com } 16 \% \text { da } \\
\text { amostra, prefere produtos de suínos com } \\
\text { qualidade definida pelo cliente, que é mais } \\
\text { característica de um tipo industrial de } \\
\text { produção, e portanto são chamados de } \\
\text { "ambientalmente conscientes"; o terceiro } \\
\text { cluster, com 12,5\% da amostra, é } \\
\text { caracterizado como cidadãos "orientados } \\
\text { para a tradição e o bem-estar animal". }\end{array}$ \\
\hline $\begin{array}{l}\text { Scholderer et al (2009), } \\
\text { documento submetido para } \\
\text { publicação. }\end{array}$ & $\begin{array}{l}\vec{E} \text { apresentado um novo método de } \\
\text { segmentação que representa produtos, } \\
\text { pessoas e diferentes aspectos do } \\
\text { ambiente de consumo (localização } \\
\text { física, contexto temporal, situação } \\
\text { social) em um espaço comum. O } \\
\text { espaço comum é construído pela } \\
\text { análise de correspondência múltipla. A } \\
\text { heterogeneidade é modelada por } \\
\text { misturas finitas. A metodologia é } \\
\text { aplicada a um caso exemplo, uma } \\
\text { pesquisa de padrões de uso do produto } \\
\text { entre consumidores europeus de carne } \\
\text { suína. Utilizaram-se os dados de uma } \\
\text { pesquisa tipo painel de acesso online } \\
\text { feita pela TNS com } 2.437 \text { pessoas. } \\
\text { Amostras praticamente iguais foram } \\
\text { obtidas na Bélgica, Dinamarca, } \\
\text { Polônia, Alemanha e Grécia, e os } \\
\text { produtos foram } 26 \text {, consumidos em } \\
\text { todos os países europeus. }\end{array}$ & $\begin{array}{l}\text { Cinco dos segmentos resultantes tiveram } \\
\text { interpretação clara, tanto em termos dos } \\
\text { produtos protótipo, que são consumidos } \\
\text { pelos membros do segmento ou em termos } \\
\text { da localização física, o contexto temporal, } \\
\text { ou a situação social em que o consumo } \\
\text { acontece: Segmento } 1 \text { (19,5\% dos } \\
\text { consumidores) - tipicamente comem carne } \\
\text { suína sozinhos, os produtos neste segmento } \\
\text { são produtos de conveniência como pizza, } \\
\text { mas também produtos tradicionais de baixo } \\
\text { valor. Segmento } 2 \text { (20\%) - consomem carne } \\
\text { suína tipicamente nos finais de semana, } \\
\text { porém não há nenhum produto que os } \\
\text { diferencie dos demais segmentos. Segmento } \\
3 \text { ( } 19,2 \%) \text { - consomem carne suína em } \\
\text { ocasiões especiais, sempre em companhia } \\
\text { de amigos e em restaurantes. Segmento } 4 \\
(16,0 \%)-\text { pessoas de família, que } \\
\text { consomem carne suína em casa em dias de } \\
\text { semana em companhia de suas famílias. } \\
\text { Segmento } 5 \text { (6\%) - consomem carne suína } \\
\text { regularmente, mas tipicamente no caminho } \\
\text { ou em "outros" locais e em companhia de } \\
\text { "outros", e não há nenhum produto } \\
\text { específico que os diferencie. }\end{array}$ \\
\hline $\begin{array}{lrr}\text { Sorensen e } & \begin{array}{l}\text { Scholderer } \\
\text { (2009), }\end{array} \\
\text { submustido para } & \text { publicação. }\end{array}$ & $\begin{array}{l}\text { Pesquisa com o objetivo de avaliar o } \\
\text { processo através do qual os cidadãos } \\
\text { europeus fazem suas avaliações de } \\
\text { sistemas de produção de suínos. 1.931 } \\
\text { consumidores da Bélgica, Alemanha, } \\
\text { Polônia e Dinamarca participaram da } \\
\text { pesquisa, que mediu orientações } \\
\text { pessoais de valor e uma larga extensão } \\
\text { de construtos de atitude. Além disso, } \\
\text { incluiu uma parte de análise conjunta } \\
\text { por meio da qual foram medidas as } \\
\text { avaliações dos participantes sobre as } \\
\text { características da produção. Os dados } \\
\text { foram analisados por meio de } \\
\text { algoritmos de busca causal e } \\
\text { modelagem de equações estruturais. }\end{array}$ & $\begin{array}{l}\text { Em todos os países, alta densidade de } \\
\text { produção teve uma influência negativa na } \\
\text { utilidade, enquanto o nível mais baixo de } \\
\text { densidade produziu as mais altas utilidades } \\
\text { parciais, exceto para Polônia e Bélgica. Em } \\
\text { termos de impacto no solo, ar e água, houve } \\
\text { um claro aumento monotônico nas } \\
\text { utilidades parciais indo de "esforço } \\
\text { mínimo" para reduzir o impacto ecológico a } \\
\text { um "máximo esforço". O atributo mais } \\
\text { importante, com } 31,41 \% \text { das preferências } \\
\text { foi o tipo de alojamento, seguido por } \\
\text { impacto no solo, ar e água (23,39\%). O } \\
\text { atributo com menor impacto foi o tipo de } \\
\text { cadeia/qualidade do produto (15,71\%), } \\
\text { densidade da produção }(14,96 \%) \text { e saúde em } \\
\text { termos de gordura }(14,54 \%) \text {. }\end{array}$ \\
\hline
\end{tabular}




\begin{tabular}{|c|c|c|}
\hline $\begin{array}{l}\text { Verbeke et al (2009), } Q- \\
\text { PorkChains } \\
\text { interno). }\end{array}$ & $\begin{array}{l}\text { Uma pesquisa quantitativa das atitudes } \\
\text { dos cidadãos europeus em relação aos } \\
\text { sistemas de produção de carne suína foi } \\
\text { realizada dentro do projeto } Q- \\
\text { PorkChains usando dados empíricos } \\
\text { coletados de } 1.931 \text { domicílios em } \\
\text { quatro países europeus (Bélgica, } \\
\text { Dinamarca, Polônia e Alemanha). O } \\
\text { objetivo geral do estudo foi mapear as } \\
\text { atitudes das pessoas em relação a } \\
\text { sistemas de produção de suínos e } \\
\text { investigar se essas atitudes se associam } \\
\text { com o consumo de carne suína e } \\
\text { produtos derivados. Para realizar esse } \\
\text { objetivo, o estudo foi dividido em duas } \\
\text { partes: segmentação tarefa } 1 \text {, baseada } \\
\text { nas atitudes dos respondentes em } \\
\text { relação a produção de suínos e suas } \\
\text { características, e segmentação tarefa } 2 \text {, } \\
\text { baseada no comportamento de } \\
\text { consumo dos respondentes em relação } \\
\text { à carne suína e produtos derivados. }\end{array}$ & $\begin{array}{l}\text { No nível } 1 \text { da segmentação, os resultados da } \\
\text { amostra mostram que as pessoas dão mais } \\
\text { importância ao bem-estar animal e ao meio } \\
\text { ambiente como critério para discriminar } \\
\text { entre "boas" e "más" práticas de criação de } \\
\text { suínos. Além disso, análises mais profundas } \\
\text { permitiram o aparecimento de três clusters } \\
\text { pequenos e bem definidos, que dão atenção } \\
\text { a atributos específicos da criação de suínos } \\
\text { (ambientalmente consciente, consciente do } \\
\text { bem-estar animal, e respondentes que } \\
\text { apoiam a pequena criação "verde" de } \\
\text { suínos), além de um cluster que cobre a } \\
\text { maioria de cidadãos medianos e e } \\
\text { ambivalentes. No nível } 2 \text { da segmentação, } \\
\text { os resultados indicam que as frequências de } \\
\text { consumo de carne suína são relativamente } \\
\text { altas dentro da amostra geral. }\end{array}$ \\
\hline $\begin{array}{l}\text { Saab et al (2009), Q- } \\
\text { PorkChains } \\
\text { Conference. }\end{array}$ & $\begin{array}{l}\text { O principal objetivo deste estudo foi } \\
\text { fazer uma comparação entre o sistema } \\
\text { agroindustrial dos suínos no Brasil e } \\
\text { em cinco países selecionados } \\
\text { (Dinamarca, Grécia, Bélgica, Polônia e } \\
\text { Alemanha). Alguns objetivos } \\
\text { específicos são identificar e mapear as } \\
\text { atitudes e valores dos consumidores de } \\
\text { suínos, investigar a maneira como o } \\
\text { suíno está inserido na vida dos } \\
\text { consumidores, verificar se existe } \\
\text { relação entre as atitudes dos cidadãos } \\
\text { em relação à produção de suínos e o } \\
\text { consumo de carne suína. Para tanto, foi } \\
\text { aplicado um questionário a cerca de } \\
480 \text { respondentes em cada um desses } \\
\text { países. No Brasil, devido a sua } \\
\text { extensão, os dados foram coletados por } \\
\text { meio de entrevista pessoal em oito } \\
\text { cidades localizadas em duas regiões } \\
\text { diferentes do Brasil, com diferentes } \\
\text { características de produção de suínos. }\end{array}$ & $\begin{array}{l}\text { Os dados coletados ainda estão sendo } \\
\text { analisados, mas alguns resultados já foram } \\
\text { encontrados, especialmente em relação ao } \\
\text { consumo e também como a amostra avalia } \\
\text { os produtos como consumidores. Os } \\
\text { resultados mostraram um alto nível de } \\
\text { penetração dos } 11 \text { produtos investigados. } \\
\text { Obteve-se também como resultado a } \\
\text { frequência de consumo, o local e maneira de } \\
\text { compra e consumo, o grau de preparo dos } \\
\text { produtos, as ocasiões, companhia e local } \\
\text { onde os produtos de carne suína são } \\
\text { consumidos, a satisfação dos consumidores } \\
\text { com relação aos produtos (em geral, com o } \\
\text { preço, o sabor e suas qualidades saudáveis). } \\
\text { Mais análises serão feitas incluindo os } \\
\text { dados sobre atitudes e se as atitudes } \\
\text { influenciam o consumo. Então, pretende-se } \\
\text { fazer uma comparação com os resultados da } \\
\text { amostra da Europa a fim de verificar as } \\
\text { principais diferenças e similaridades entre } \\
\text { ambos. }\end{array}$ \\
\hline $\begin{array}{l}\text { Kehagia et al (2010), } Q- \\
\text { PorkChains } \\
\text { interno). }\end{array}$ & $\begin{array}{l}\text { É feita uma análise em que se desafia a } \\
\text { afirmação básica do propósito da } \\
\text { adaptação/padronização, por meio de } \\
\text { um estudo comparando dados da } \\
\text { Europa, China e Brasil. Utilizando o } \\
\text { instrumento Food Related Lifestyle } \\
\text { (FRL), os autores argumentam que a } \\
\text { maneira de fazer compras, aspectos de } \\
\text { qualidade e motivos de compra dos } \\
\text { consumidores na China e no Brasil têm }\end{array}$ & $\begin{array}{l}\text { Os autores fazem sugestões que buscam } \\
\text { facilitar a penetração de firmas nesses } \\
\text { grandes mercados emergentes (China e } \\
\text { Brasil), mostrando que no caso desses dois } \\
\text { países é difícil obter sucesso por meio da } \\
\text { padronização. }\end{array}$ \\
\hline
\end{tabular}




\begin{tabular}{|c|c|c|}
\hline & $\begin{array}{l}\text { um papel de influência para a } \\
\text { adaptação de táticas de marketing. }\end{array}$ & \\
\hline $\begin{array}{l}\text { Verbeke et al (2010), Meat } \\
\text { Science. }\end{array}$ & $\begin{array}{l}\text { O trabalho apresenta os resultados } \\
\text { combinados de dois projetos da União } \\
\text { Europeia relacionados a carne, o } \\
\text { ProSafeBeef e o Q-PorkChains. A } \\
\text { parte de consumidores do ProSafeBeef } \\
\text { realizou oito discussões de focus group } \\
\text { em maio de } 2008 \text { na França, } \\
\text { Alemanha, Espanha e Reino Unido. Já } \\
\text { o Q-PorkChains conduziu uma } \\
\text { pesquisa em larga escala pela web em } \\
\text { janeiro de } 2008 \text { na Bélgica, Dinamarca, } \\
\text { Alemanha, Grécia e Polônia. O } \\
\text { primeiro projeto oferece um conjunto } \\
\text { de dados qualitativos de uma pequena } \\
\text { amostra e o segundo, um conjunto de } \\
\text { dados quantitativos de uma amostra } \\
\text { maior. Aqui são apresentadas as } \\
\text { principais conclusões de ambos os } \\
\text { projetos e é oferecida uma visão geral } \\
\text { das atitudes e preferências dos cidadãos } \\
\text { e dos consumidores europeus a respeito } \\
\text { de carne bovina e suína. }\end{array}$ & $\begin{array}{l}\text { Em geral, os consumidores consideram a } \\
\text { carne um saudável e importante componente } \\
\text { da dieta. Os consumidores apoiam o } \\
\text { desenvolvimento de tecnologias que podem } \\
\text { melhorar os atributos de saúde de produtos } \\
\text { de carne e garantir a qualidade do alimento, } \\
\text { mas têm uma visão negativa do que } \\
\text { imaginam ser uma excessiva manipulação e } \\
\text { falta de naturalidade na produção e } \\
\text { processamento de produtos de carne bovina. } \\
\text { No estudo Q-PorkChains são identificados e } \\
\text { caracterizados segmentos de consumidores e } \\
\text { cidadãos. Os segmentos de consumidores } \\
\text { foram criados a partir da frequência e } \\
\text { variedade de consumo de carne suína. Os } \\
\text { segmentos de cidadãos foram criados com } \\
\text { base em suas atitudes em relação a sistemas } \\
\text { de produção de suínos. De maneira geral, } \\
\text { descobriu-se que o relacionamento entre as } \\
\text { visões dos indivíduos como cidadãos e seu } \\
\text { comportamento como consumidores é } \\
\text { relativamente fraco e não parece influenciar } \\
\text { grandemente ou sistematicamente os hábitos } \\
\text { de compra de carne. }\end{array}$ \\
\hline $\begin{array}{l}\text { Pérez-Cueto et al (2010), } \\
\text { Appetite. }\end{array}$ & $\begin{array}{l}\text { O objetivo do trabalho foi investigar as } \\
\text { associações entre obesidade e o FRL } \\
\text { em cinco países europeus. Uma } \\
\text { pesquisa cross-seccional baseada na } \\
\text { web foi realizada na Bélgica, } \\
\text { Dinamarca, Alemanha, Grécia e } \\
\text { Polônia em janeiro de 20008, com cotas } \\
\text { pré-especificadas para gênero, idade e } \\
\text { local de residência. Um total de } 2.437 \\
\text { respondentes participou. Os dados } \\
\text { obtidos incluíam informações } \\
\text { sociodemográficas, medidas da escala } \\
F R L \text { e peso e medida autorreportados. } \\
\text { O IMC foi calculado como o peso (em } \\
\text { kg) dividido pela altura ao quadrado } \\
\text { (em m²). Foram feitas regressões } \\
\text { logísticas para a amostra agregada e } \\
\text { depois por país, com obesos como } \\
\text { variável dependente, e dados } \\
\text { sociodemográficos e FRL como } \\
\text { independentes. }\end{array}$ & $\begin{array}{l}\text { A prevalência da obesidade nos cinco países } \\
\text { é de 22\%. Europeus que dão maior } \\
\text { importância a a 'autorrealização', } \\
\text { 'planejamento das refeições', e preferência } \\
\text { por 'lanches ou refeiços' têm mais chances } \\
\text { de serem obesos. Os respondents eram } \\
\text { menos predispostos a serem obesos se } \\
\text { dessem níveis mais baixos de importância } \\
\text { ao uso de 'listas de compras'. O desenho } \\
\text { geral é que um interesse mais forte em } \\
\text { saúde, produtos orgânicos e frescor, dentro } \\
\text { dos aspectos de qualidade do FRL está } \\
\text { associado a 'não ser obeso'. Este estudo } \\
\text { identificou dimensões específicas do FRL } \\
\text { como preditores potenciais da obesidade. Os } \\
\text { perfis resultantes dos consumidores podem } \\
\text { ser usados para intervenções focadas para } \\
\text { trabalhos relacionados à obesidade na } \\
\text { Europa. }\end{array}$ \\
\hline $\begin{array}{l}\text { Resano et al }(2010), \\
\text { Nutrición Hospitalaria. }\end{array}$ & $\begin{array}{l}\text { Dentro de um projeto pan-Europeu } \\
\text { maior de pesquisa baseado na web, foi } \\
\text { realizada uma pesquisa de consumo em } \\
\text { janeiro de } 2008 \text { em cinco países } \\
\text { europeus para investigar possíveis } \\
\text { associações entre obesidade e } \\
\text { satisfação geral com produtos de carne } \\
\text { suína e produtos baseados e derivados } \\
\text { da carne suína. Uma vez que os }\end{array}$ & $\begin{array}{l}\text { Comparados a consumidores belgas, os } \\
\text { alemães pareciam estar mais satisfeitos com } \\
\text { a carne suína, enquanto os dinamarqueses } \\
\text { não. Respondentes com melhor situação } \\
\text { econômica pareciam menos satisfeitos com } \\
\text { carne suína que os com situação pior, o que } \\
\text { provavelmente reflete uma gradação } \\
\text { socioeconômica no uso e avaliação de carne } \\
\text { suína. Mais importante, os europeus obesos }\end{array}$ \\
\hline
\end{tabular}




\begin{tabular}{|c|c|c|}
\hline & $\begin{array}{l}\text { determinantes da obesidade } r a ̃ o \\
\text { diversos, partiu-se da hipótese de que } \\
\text { características específicas dos } \\
\text { consumidores, como satisfação geral } \\
\text { com a carne suína e produtos } \\
\text { derivados, podem tornar-se tanto uma } \\
\text { oportunidade como uma ameaça para } \\
\text { programas de administração da } \\
\text { obesidade, se alguma associação com } \\
\text { obesidade pudesse ser demonstrada. De } \\
\text { um total de } 2.437 \text { consumidores, } 2.156 \\
\text { respondentes classificaram-se como } \\
\text { consumidores de carne suína e } \\
\text { reportaram seu peso e altura. }\end{array}$ & $\begin{array}{l}\text { nesta amostra eram } 1,4 \text { vezes } \\
\text { propensos a estarem satisfeitos com } \\
\text { produtos de carne suína que os } \\
\text { consumidores não obesos. Já que a } \\
\text { satisfação é uma pré-condição da compra } \\
\text { repetida e da lealdade, o estudo sugere que } \\
\text { qualquer intervenção na dieta alimentar que } \\
\text { implique a redução de produtos com os } \\
\text { quais os consumidores estejam satisfeitos } \\
\text { será uma ameaça a seu sucesso. O desafio é } \\
\text { alcançar satisfação com produtos saudáveis } \\
\text { e satisfação com dietas prescritas } \\
\text { (programas de administração da obesidade } \\
\text { ou em hospitais). }\end{array}$ \\
\hline $\begin{array}{l}\text { Resano et al (2010), } \\
\text { Appetite. }\end{array}$ & $\begin{array}{l}\text { Estudo investiga o nível de satisfação } \\
\text { do consumidor com a carne suína e } \\
\text { derivados em cinco países europeus. } \\
\text { Os dados foram coletados por meio de } \\
\text { pesquisa cross-seccional baseada na } \\
\text { web na Bélgica, Dinamarca, Grécia e } \\
\text { Polônia em janeiro de } 2008 \text {, com uma } \\
\text { amostra total de } 2.437 \text { consumidores, e } \\
\text { incluíram dados sociodemográficos e } \\
\text { questões relacionadas à satisfação com } \\
27 \text { produtos comuns, classificados } \\
\text { como carne suína fresca, carne suína } \\
\text { processada e produtos de carne suína. } \\
\text { A satisfação foi avaliada em termos de } \\
\text { satisfação geral, bem como de } \\
\text { satisfação com as qualidades saudáveis, } \\
\text { preço, conveniência e sabor. }\end{array}$ & $\begin{array}{l}\text { Análises de regressão logística mostraram o } \\
\text { sabor como o principal determinante da } \\
\text { satisfação, seguido pela conveniência. A } \\
\text { saúde não é um direcionador significante da } \\
\text { satisfação geral. O preço influencia a } \\
\text { satisfação com carne suína fresca mais do } \\
\text { que com processada. Carne suína saborosa, } \\
\text { fácil de preparar e consumir, com promoção } \\
\text { adequada de suas qualidades saudáveis e } \\
\text { com uma boa relação entre preço e } \\
\text { qualidade parece ser o fator-chave para } \\
\text { satisfazer os consumidores da carne suína. }\end{array}$ \\
\hline
\end{tabular}




\section{APÊNDICE C}

Cidades com diferença significativa de satisfação com o sabor

\begin{tabular}{|c|c|c|c|c|c|}
\hline Combinação & Frescos & Pouco Proc. & Mais Proc & Refeição & Carne \\
\hline $\begin{array}{l}\text { Porto Alegre X Santa } \\
\text { Rosa }\end{array}$ & $\mathrm{SR}>\mathrm{PA}$ & $\mathrm{SR}>\mathrm{PA}$ & $\mathrm{SR}>\mathrm{PA}$ & & $\mathrm{SR}>\mathrm{PA}$ \\
\hline Porto Alegre X Curitiba & & & $\mathrm{CR}>\mathrm{PA}$ & & $\mathrm{PA}>\mathrm{CR}$ \\
\hline \multicolumn{6}{|l|}{$\begin{array}{l}\text { Porto Alegre X Ponta } \\
\text { Grossa }\end{array}$} \\
\hline Porto Alegre X Cuiabá & & $\mathrm{PA}>\mathrm{CB}$ & & & \\
\hline $\begin{array}{l}\text { Porto Alegre X Campo } \\
\text { Verde }\end{array}$ & $\mathrm{PA}>\mathrm{CV}$ & & & $\mathrm{PA}>\mathrm{CV}$ & \\
\hline Porto Alegre X Goiânia & & & & & $\mathrm{CN}>\mathrm{PA}$ \\
\hline $\begin{array}{llll}\text { Porto } & \text { Alegre } & \text { X } & \text { Rio } \\
\text { Verde } & & & \\
\end{array}$ & & $\mathrm{RV}>\mathrm{PA}$ & & & \\
\hline Santa Rosa X Curitiba & & & & & $\mathrm{SR}>\mathrm{CR}$ \\
\hline $\begin{array}{l}\text { Santa Rosa X Ponta } \\
\text { Grossa }\end{array}$ & $\mathrm{SR}>\mathrm{PG}$ & & $\mathrm{SR}>\mathrm{PG}$ & & $\mathrm{SR}>\mathrm{PG}$ \\
\hline Santa Rosa X Cuiabá & & $\mathrm{SR}>\mathrm{CB}$ & $\mathrm{SR}>\mathrm{CB}$ & $\mathrm{SR}>\mathrm{CB}$ & $\mathrm{SR}>\mathrm{CB}$ \\
\hline $\begin{array}{l}\text { Santa Rosa X Campo } \\
\text { Verde }\end{array}$ & $\mathrm{SR}>\mathrm{CV}$ & $\mathrm{SR}>\mathrm{CV}$ & $\mathrm{SR}>\mathrm{CV}$ & $\mathrm{SR}>\mathrm{CV}$ & $\mathrm{SR}>\mathrm{CV}$ \\
\hline Santa Rosa X Goiânia & & & $\mathrm{SR}>\mathrm{GN}$ & & \\
\hline Santa Rosa X Rio Verde & $\mathrm{SR}>\mathrm{RV}$ & & SR>RV & $\mathrm{SR}>\mathrm{RV}$ & $\mathrm{SR}>\mathrm{RV}$ \\
\hline \multicolumn{6}{|l|}{ Curitiba X Ponta Grossa } \\
\hline Curitiba X Cuiabá & & $\mathrm{CR}>\mathrm{CB}$ & $\mathrm{CR}>\mathrm{CB}$ & & \\
\hline Curitiba X Campo Verde & $\mathrm{CR}>\mathrm{CV}$ & & $\mathrm{CR}>\mathrm{CV}$ & $\mathrm{CR}>\mathrm{CV}$ & \\
\hline Curitiba X Goiânia & & & & & $\mathrm{GN}>\mathrm{CR}$ \\
\hline Curitiba X Rio Verde & & & & & $\mathrm{RV}>\mathrm{CR}$ \\
\hline Ponta Grossa X Cuiabá & & $\mathrm{PG}>\mathrm{CB}$ & & & \\
\hline $\begin{array}{l}\text { Ponta Grossa X Campo } \\
\text { Verde }\end{array}$ & $\mathrm{PG}>\mathrm{CV}$ & & & $\mathrm{PG}>\mathrm{CV}$ & \\
\hline Ponta Grossa X Goiânia & & & & & $\mathrm{GN}>\mathrm{PG}$ \\
\hline \multicolumn{6}{|l|}{$\begin{array}{llll}\text { Ponta } & \text { Grossa } & \text { X } & \text { Rio } \\
\text { Verde } & & & \\
\end{array}$} \\
\hline Cuiabá X Campo Verde & $\mathrm{CB}>\mathrm{CV}$ & & & & \\
\hline Cuiabá X Goiânia & & $\mathrm{GN}>\mathrm{CB}$ & & & $\mathrm{GN}>\mathrm{CB}$ \\
\hline Cuiabá X Rio Verde & & $\mathrm{RV}>\mathrm{CB}$ & $\mathrm{RV}>\mathrm{CB}$ & & \\
\hline Campo Verde X Goiânia & & & & $\mathrm{GN}>\mathrm{CV}$ & $\mathrm{GN}>\mathrm{CV}$ \\
\hline $\begin{array}{llll}\text { Campo } & \text { Verde } & \text { X } & \text { Rio } \\
\text { Verde } & & & \\
\end{array}$ & $\mathrm{CV}>\mathrm{RV}$ & & & & \\
\hline Goiânia X Rio Verde & & & & & $\mathrm{GN}>\mathrm{RV}$ \\
\hline
\end{tabular}




\section{APÊNDICE D}

Cidades com diferença significativa de satisfação com as qualidades saudáveis dos produtos

\begin{tabular}{|c|c|c|c|c|c|}
\hline Combinação & Frescos & Pouco Proc. & Mais Proc & Refeição & Carne \\
\hline $\begin{array}{l}\text { Porto Alegre X Santa } \\
\text { Rosa }\end{array}$ & $\mathrm{SR}>\mathrm{PA}$ & $\mathrm{SR}>\mathrm{PA}$ & $\mathrm{SR}>\mathrm{PA}$ & $\mathrm{SR}>\mathrm{PA}$ & $\mathrm{SR}>\mathrm{PA}$ \\
\hline Porto Alegre X Curitiba & & & & & $\mathrm{PA}>\mathrm{CR}$ \\
\hline \multicolumn{6}{|l|}{$\begin{array}{l}\text { Porto Alegre X Ponta } \\
\text { Grossa }\end{array}$} \\
\hline Porto Alegre X Cuiabá & $\mathrm{PA}>\mathrm{CB}$ & $\mathrm{PA}>\mathrm{CB}$ & $\mathrm{PA}>\mathrm{CB}$ & $\mathrm{PA}>\mathrm{CB}$ & $\mathrm{PA}>\mathrm{CB}$ \\
\hline $\begin{array}{l}\text { Porto Alegre X Campo } \\
\text { Verde }\end{array}$ & $\mathrm{PA}>\mathrm{CV}$ & & & & $\mathrm{PA}>\mathrm{CV}$ \\
\hline Porto Alegre X Goiânia & & & & & $\mathrm{PA}>\mathrm{GN}$ \\
\hline $\begin{array}{llll}\text { Porto } & \text { Alegre } & X & \text { Rio } \\
\text { Verde } & & & \\
\end{array}$ & & & & & $\mathrm{PA}>\mathrm{RV}$ \\
\hline Santa Rosa X Curitiba & SR>CR & SR>CR & $\mathrm{SR}>\mathrm{CR}$ & SR>CR & $\mathrm{SR}>\mathrm{CR}$ \\
\hline $\begin{array}{llll}\text { Santa Rosa } & \text { X } & \text { Ponta } \\
\text { Grossa } & & & \\
\end{array}$ & $\mathrm{SR}>\mathrm{PG}$ & & SR>PG & SR>PG & SR>PG \\
\hline Santa Rosa X Cuiabá & $\mathrm{SR}>\mathrm{CB}$ & $\mathrm{SR}>\mathrm{CB}$ & $\mathrm{SR}>\mathrm{CB}$ & $\mathrm{SR}>\mathrm{CB}$ & $\mathrm{SR}>\mathrm{CB}$ \\
\hline $\begin{array}{llll}\text { Santa Rosa X Campo } \\
\text { Verde }\end{array}$ & $\mathrm{SR}>\mathrm{CV}$ & $\mathrm{SR}>\mathrm{CV}$ & $\mathrm{SR}>\mathrm{CV}$ & $\mathrm{SR}>\mathrm{CV}$ & $\mathrm{SR}>\mathrm{CV}$ \\
\hline Santa Rosa X Goiânia & SR>GN & SR>GN & $\mathrm{SR}>\mathrm{GN}$ & SR>GN & $\mathrm{SR}>\mathrm{GN}$ \\
\hline Santa Rosa X Rio Verde & $\mathrm{SR}>\mathrm{RV}$ & $\mathrm{SR}>\mathrm{RV}$ & $\mathrm{SR}>\mathrm{RV}$ & SR>RV & $\mathrm{SR}>\mathrm{RV}$ \\
\hline Curitiba X Ponta Grossa & $\mathrm{PG}>\mathrm{CR}$ & $\mathrm{PG}>\mathrm{CR}$ & & $\mathrm{PG}>\mathrm{CR}$ & $\mathrm{PG}>\mathrm{CR}$ \\
\hline Curitiba X Cuiabá & $\mathrm{CR}>\mathrm{CB}$ & $\mathrm{CR}>\mathrm{CB}$ & $\mathrm{CR}>\mathrm{CB}$ & $\mathrm{CR}>\mathrm{CB}$ & $\mathrm{CR}>\mathrm{CB}$ \\
\hline Curitiba X Campo Verde & $\mathrm{CR}>\mathrm{CV}$ & & & & \\
\hline \multicolumn{6}{|l|}{ Curitiba X Goiânia } \\
\hline \multicolumn{6}{|l|}{ Curitiba X Rio Verde } \\
\hline Ponta Grossa X Cuiabá & $\mathrm{PG}>\mathrm{CB}$ & $\mathrm{PG}>\mathrm{CB}$ & $\mathrm{PG}>\mathrm{CB}$ & $\mathrm{PG}>\mathrm{CB}$ & $\mathrm{PG}>\mathrm{CB}$ \\
\hline $\begin{array}{l}\text { Ponta Grossa X Campo } \\
\text { Verde }\end{array}$ & $\mathrm{PG}>\mathrm{CV}$ & & & $\mathrm{PG}>\mathrm{CV}$ & $\mathrm{PG}>\mathrm{CV}$ \\
\hline Ponta Grossa X Goiânia & PG>GN & PG>GN & & & $\mathrm{PG}>\mathrm{GN}$ \\
\hline 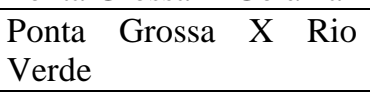 & PG>RV & & & $\mathrm{PG}>\mathrm{RV}$ & \\
\hline Cuiabá X Campo Verde & & $\mathrm{CV}>\mathrm{CB}$ & & $\mathrm{CV}>\mathrm{CB}$ & $\mathrm{CV}>\mathrm{CB}$ \\
\hline Cuiabá X Goiânia & $\mathrm{GN}>\mathrm{CB}$ & $\mathrm{GN}>\mathrm{CB}$ & $\mathrm{GN}>\mathrm{CB}$ & $\mathrm{GN}>\mathrm{CB}$ & $\mathrm{GN}>\mathrm{CB}$ \\
\hline Cuiabá X Rio Verde & $\mathrm{RV}>\mathrm{CB}$ & $\mathrm{RV}>\mathrm{CB}$ & $\mathrm{RV}>\mathrm{CB}$ & $\mathrm{RV}>\mathrm{CB}$ & $\mathrm{RV}>\mathrm{CB}$ \\
\hline Campo Verde X Goiânia & $\mathrm{GN}>\mathrm{CV}$ & & & & $\mathrm{GN}>\mathrm{CV}$ \\
\hline $\begin{array}{llll}\text { Campo } & \text { Verde } & \text { X } & \text { Rio } \\
\text { Verde } & & & \\
\end{array}$ & $\mathrm{RV}>\mathrm{CV}$ & & & & $\mathrm{RV}>\mathrm{CV}$ \\
\hline Goiânia X Rio Verde & & & & & \\
\hline
\end{tabular}




\section{APÊNDICE E}

Cidades com diferença significativa de facilidade de preparo

\begin{tabular}{|c|c|c|c|}
\hline Combinação & Frescos & Refeição & Carne \\
\hline $\begin{array}{l}\text { Porto Alegre X Santa } \\
\text { Rosa }\end{array}$ & & & $\mathrm{SR}>\mathrm{PA}$ \\
\hline \multicolumn{4}{|l|}{ Porto Alegre X Curitiba } \\
\hline $\begin{array}{l}\text { Porto Alegre X Ponta } \\
\text { Grossa }\end{array}$ & $\mathrm{PG}>\mathrm{PA}$ & $\mathrm{PG}>\mathrm{PA}$ & \\
\hline Porto Alegre X Cuiabá & & $\mathrm{CB}>\mathrm{PA}$ & $\mathrm{PA}>\mathrm{CB}$ \\
\hline $\begin{array}{l}\text { Porto Alegre X Campo } \\
\text { Verde }\end{array}$ & & $\mathrm{CV}>\mathrm{PA}$ & $\mathrm{PA}>\mathrm{CV}$ \\
\hline \multicolumn{4}{|l|}{ Porto Alegre X Goiânia } \\
\hline \multicolumn{4}{|l|}{$\begin{array}{llll}\text { Porto } & \text { Alegre } & \text { X } & \text { Rio } \\
\text { Verde } & & & \\
\end{array}$} \\
\hline Santa Rosa X Curitiba & & $\mathrm{CR}>\mathrm{SR}$ & $\mathrm{SR}>\mathrm{CR}$ \\
\hline $\begin{array}{llll}\text { Santa Rosa } & \text { X } & \text { Ponta } \\
\text { Grossa } & & & \\
\end{array}$ & $\mathrm{PG}>\mathrm{SR}$ & $\mathrm{PG}>\mathrm{SR}$ & $\mathrm{SR}>\mathrm{PG}$ \\
\hline Santa Rosa X Cuiabá & & $\mathrm{CB}>\mathrm{SR}$ & $\mathrm{SR}>\mathrm{CB}$ \\
\hline $\begin{array}{llll}\text { Santa } & \text { Rosa X Campo } \\
\text { Verde } & & & \\
\end{array}$ & & $\mathrm{CV}>\mathrm{SR}$ & $\mathrm{SR}>\mathrm{CV}$ \\
\hline Santa Rosa X Goiânia & & & $\mathrm{SR}>\mathrm{GN}$ \\
\hline Santa Rosa X Rio Verde & & $\mathrm{RV}>\mathrm{SR}$ & $\mathrm{SR}>\mathrm{RV}$ \\
\hline Curitiba X Ponta Grossa & $\mathrm{PG}>\mathrm{CR}$ & & \\
\hline \multicolumn{4}{|l|}{ Curitiba X Cuiabá } \\
\hline Curitiba X Campo Verde & & & $\mathrm{CR}>\mathrm{CV}$ \\
\hline Curitiba X Goiânia & $\mathrm{GN}>\mathrm{CR}$ & & \\
\hline Curitiba X Rio Verde & $\mathrm{RV}>\mathrm{CR}$ & & \\
\hline Ponta Grossa X Cuiabá & $\mathrm{PG}>\mathrm{CB}$ & & \\
\hline $\begin{array}{l}\text { Ponta Grossa X Campo } \\
\text { Verde }\end{array}$ & $\mathrm{PG}>\mathrm{CV}$ & & $\mathrm{PG}>\mathrm{CV}$ \\
\hline \multicolumn{4}{|l|}{ Ponta Grossa X Goiânia } \\
\hline \multicolumn{4}{|l|}{$\begin{array}{llll}\text { Ponta } & \text { Grossa } & \text { X } & \text { Rio } \\
\text { Verde } & & & \\
\end{array}$} \\
\hline Cuiabá X Campo Verde & & & $\mathrm{CB}>\mathrm{CV}$ \\
\hline Cuiabá X Goiânia & $\mathrm{GN}>\mathrm{CB}$ & & \\
\hline Cuiabá X Rio Verde & $\mathrm{RV}>\mathrm{CB}$ & & \\
\hline Campo Verde X Goiânia & & & $\mathrm{GN}>\mathrm{RV}$ \\
\hline $\begin{array}{llll}\text { Campo } & \text { Verde } & \text { X Rio } \\
\text { Verde } & & & \\
\end{array}$ & $\mathrm{RV}>\mathrm{CV}$ & & $\mathrm{RV}>\mathrm{CV}$ \\
\hline Goiânia X Rio Verde & & & \\
\hline
\end{tabular}




\section{APÊNDICE F}

Cidades com diferença significativa de satisfação com o preço

\begin{tabular}{|c|c|c|c|c|c|}
\hline Combinação & Frescos & Pouco Proc. & Mais Proc & Refeição & Carne \\
\hline \multicolumn{6}{|l|}{$\begin{array}{llll}\text { Porto Alegre X Santa } \\
\text { Rosa }\end{array}$} \\
\hline Porto Alegre X Curitiba & $\mathrm{PA}>\mathrm{CR}$ & & $\mathrm{PA}>\mathrm{CR}$ & $\mathrm{PA}>\mathrm{CR}$ & $\mathrm{PA}>\mathrm{CR}$ \\
\hline $\begin{array}{lll}\text { Porto Alegre X Ponta } \\
\text { Grossa }\end{array}$ & & $\mathrm{PG}>\mathrm{PA}$ & & & \\
\hline Porto Alegre X Cuiabá & $\mathrm{PA}>\mathrm{CB}$ & $\mathrm{PA}>\mathrm{CB}$ & $\mathrm{PA}>\mathrm{CB}$ & $\mathrm{PA}>\mathrm{CB}$ & $\mathrm{PA}>\mathrm{CB}$ \\
\hline $\begin{array}{l}\text { Porto Alegre X Campo } \\
\text { Verde }\end{array}$ & $\mathrm{PA}>\mathrm{CV}$ & & & & $\mathrm{PA}>\mathrm{CV}$ \\
\hline Porto Alegre X Goiânia & $\mathrm{PA}>\mathrm{GN}$ & & & & $\mathrm{PA}>\mathrm{GN}$ \\
\hline $\begin{array}{llll}\text { Porto } & \text { Alegre } & X & \text { Rio } \\
\text { Verde } & & & \\
\end{array}$ & $\mathrm{PA}>\mathrm{RV}$ & & & $\mathrm{PA}>\mathrm{RV}$ & $\mathrm{PA}>\mathrm{RV}$ \\
\hline Santa Rosa X Curitiba & $S R>C R$ & $\mathrm{SR}>\mathrm{CR}$ & $\mathrm{SR}>\mathrm{CR}$ & $S R>C R$ & $\mathrm{SR}>\mathrm{CR}$ \\
\hline $\begin{array}{llll}\text { Santa Rosa } & \text { X } & \text { Ponta } \\
\text { Grossa } & & & \\
\end{array}$ & & $\mathrm{PG}>\mathrm{SR}$ & & $\mathrm{PG}>\mathrm{SR}$ & \\
\hline Santa Rosa X Cuiabá & $\mathrm{SR}>\mathrm{CB}$ & $\mathrm{SR}>\mathrm{CB}$ & $\mathrm{SR}>\mathrm{CB}$ & $\mathrm{SR}>\mathrm{CB}$ & $\mathrm{SR}>\mathrm{CB}$ \\
\hline $\begin{array}{llll}\text { Santa Rosa X Campo } \\
\text { Verde }\end{array}$ & $\mathrm{SR}>\mathrm{CV}$ & & & & $\mathrm{SR}>\mathrm{CV}$ \\
\hline Santa Rosa X Goiânia & $\mathrm{SR}>\mathrm{GN}$ & & & & \\
\hline Santa Rosa X Rio Verde & $S R>R V$ & $S R>R V$ & & & $\mathrm{SR}>\mathrm{RV}$ \\
\hline Curitiba X Ponta Grossa & $\mathrm{PG}>\mathrm{CR}$ & $\mathrm{PG}>\mathrm{CR}$ & $\mathrm{PG}>\mathrm{CR}$ & $\mathrm{PG}>\mathrm{CR}$ & $\mathrm{PG}>\mathrm{CR}$ \\
\hline Curitiba X Cuiabá & $\mathrm{CR}>\mathrm{CB}$ & & & & $\mathrm{CR}>\mathrm{CB}$ \\
\hline Curitiba X Campo Verde & & $\mathrm{CV}>\mathrm{CR}$ & $\mathrm{CV}>\mathrm{CR}$ & $\mathrm{CV}>\mathrm{CR}$ & \\
\hline Curitiba X Goiânia & $\mathrm{GN}>\mathrm{CR}$ & & $\mathrm{GN}>\mathrm{CR}$ & $\mathrm{GN}>\mathrm{CR}$ & \\
\hline \multicolumn{6}{|l|}{ Curitiba X Rio Verde } \\
\hline Ponta Grossa X Cuiabá & $\mathrm{PG}>\mathrm{CB}$ & $\mathrm{PG}>\mathrm{CB}$ & $\mathrm{PG}>\mathrm{CB}$ & $\mathrm{PG}>\mathrm{CB}$ & $\mathrm{PG}>\mathrm{CB}$ \\
\hline $\begin{array}{l}\text { Ponta Grossa X Campo } \\
\text { Verde }\end{array}$ & $\mathrm{PG}>\mathrm{CV}$ & & & $\mathrm{PG}>\mathrm{CV}$ & $\mathrm{PG}>\mathrm{CV}$ \\
\hline Ponta Grossa X Goiânia & & $\mathrm{PG}>\mathrm{GN}$ & & $\mathrm{PG}>\mathrm{GN}$ & $\mathrm{PG}>\mathrm{GN}$ \\
\hline $\begin{array}{llll}\text { Ponta } & \text { Grossa } & X & \text { Rio } \\
\text { Verde } & & & \\
\end{array}$ & $\mathrm{PG}>\mathrm{RV}$ & $\mathrm{PG}>\mathrm{RV}$ & & $\mathrm{PG}>\mathrm{RV}$ & $\mathrm{PG}>\mathrm{RV}$ \\
\hline Cuiabá X Campo Verde & $\mathrm{CV}>\mathrm{CB}$ & $\mathrm{CV}>\mathrm{CB}$ & $\mathrm{CV}>\mathrm{CB}$ & $\mathrm{CV}>\mathrm{CB}$ & $\mathrm{CV}>\mathrm{CB}$ \\
\hline Cuiabá X Goiânia & $\mathrm{GN}>\mathrm{CB}$ & & $\mathrm{GN}>\mathrm{CB}$ & $\mathrm{GN}>\mathrm{CB}$ & $\mathrm{GN}>\mathrm{CB}$ \\
\hline Cuiabá X Rio Verde & $\mathrm{RV}>\mathrm{CB}$ & & & & \\
\hline Campo Verde X Goiânia & & $\mathrm{CV}>\mathrm{GN}$ & & & \\
\hline $\begin{array}{lll}\text { Campo Verde X Rio } \\
\text { Verde }\end{array}$ & & $\mathrm{CV}>\mathrm{RV}$ & $\mathrm{CV}>\mathrm{RV}$ & $\mathrm{CV}>\mathrm{RV}$ & \\
\hline Goiânia X Rio Verde & $\mathrm{GN}>\mathrm{RV}$ & & & & $\mathrm{GN}>\mathrm{RV}$ \\
\hline
\end{tabular}

